UNIVERSIDADE DE SÃO PAULO
ESCOLA DE COMUNICAÇÕES E ARTES
PROGRAMA DE PÓS-GRADUAÇÃO EM CIÊNCIAS DA COMUNICAÇÃO

CAROLINA DOS SANTOS VELLEI

OS STORIES JORNALÍSTICOS NO INSTAGRAM: INVESTIGANDO OS NOVOS FORMATOS DE NARRATIVAS NAS MÍDIAS SOCIAIS

São Paulo 


\author{
UNIVERSIDADE DE SÃO PAULO \\ ESCOLA DE COMUNICAÇÕES E ARTES \\ PROGRAMA DE PÓS-GRADUAÇÃO EM CIÊNCIAS DA COMUNICAÇÃO
}

CAROLINA DOS SANTOS VELLEI

\title{
OS STORIES JORNALÍSTICOS NO INSTAGRAM: INVESTIGANDO OS NOVOS FORMATOS DE NARRATIVAS NAS MÍDIAS SOCIAIS
}

\section{Versão Corrigida}

Dissertação apresentada ao Programa de Pósgraduação em Ciências da Comunicação da Escola de Comunicações e Artes da Universidade de São Paulo como requisito para a obtenção do título de Mestra em Ciências da Comunicação.

Área de concentração: Ciências da Comunicação Linha de pesquisa: Processos comunicacionais: tecnologias, produção e consumos

Orientador: Prof. Dr. Wagner Souza e Silva

São Paulo 
Autorizo a reprodução e divulgação total ou parcial deste trabalho, por qualquer meio convencional ou eletrônico, para fins de estudo e pesquisa, desde que citada a fonte.

\section{Versão corrigida}

Catalogação na Publicação

Serviço de Biblioteca e Documentação

Escola de Comunicaçōes e Artes da Universidade de São Paulo

Dados inseridos pelo(a) autor(a)

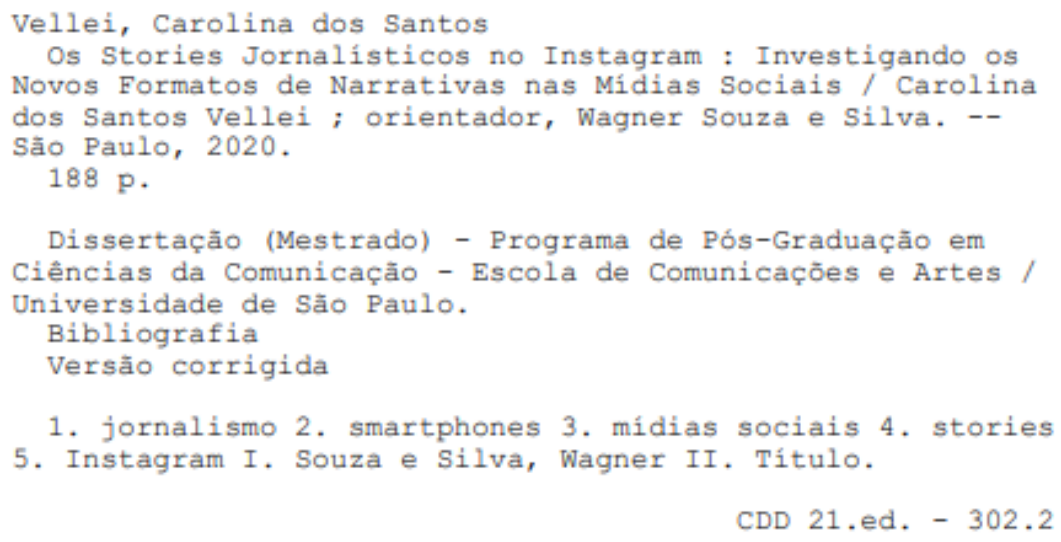


Nome: VELLEI, Carolina dos Santos

Título: Os stories jornalísticos no Instagram: investigando os novos formatos de narrativas nas mídias sociais

Dissertação apresentada à Escola de Comunicações e Artes da Universidade de São Paulo para obtenção do título de Mestra em Ciências da Comunicação

Aprovada em:

Banca Examinadora

Prof. Dr.

Instituição:

Julgamento:

Profa.Dra.

Instituição:

Julgamento:

Profa.Dra.

Instituição:

Julgamento: 
Dedico esse trabalho aos jovens que participam ativamente dos fluxos comunicacionais da sociedade e que se empoderam cada dia mais para realizar as necessárias mudanças planetárias em prol de toda a natureza e a humanidade. Além deles, dedico esse trabalho principalmente àqueles jovens que ainda não participam desse processo para que um dia também se empoderem e juntem-se aos demais na luta por um mundo melhor. 


\section{AGRADECIMENTOS}

Gosto de ler essa parte nos outros trabalhos porque quase sempre nos mostra, por trás de todas as regras da ABNT, a faceta humana do autor. Nesse caso, da autora. (-)

Cheguei até aqui graças à ajuda dos meus amigos de luz do plano espiritual, que sempre me guiaram e me protegeram na atuação em prol da energia criadora de tudo: Deus. Por isso (e por tudo), gratidão a vocês, meus irmãos!

Agradeço do fundo do meu coração a minha família e aqui eu não conseguiria expressar em palavras o quanto eles representam um porto seguro para mim e o quanto sou grata por ter nascido junto a eles.

Agradeço aos meus amigos, que sempre me apoiaram e torceram pelo meu sucesso, em especial ao Danilo por me ajudar com o abstract e ao William pela motivação.

Agradeço ao Sr. Luiz e a D. Áurea por terem me oferecido acolhida na Casa do Caminho. Também agradeço aos meus parceiros de Evangelização Infantil, Joyce e Raphael, por terem me guiado em direção ao trabalho de amor na educação espiritual. Sempre serei grata por terem me apresentado a esse bálsamo no período de mestrado.

Agradeço profundamente ao meu orientador, Prof. Wagner, por ter sido um grande farol na minha caminhada acadêmica, desde a época da graduação. Sem você esse trabalho não seria possível!

Agradeço imensamente às professoras que estiveram em minha banca de qualificação, Prof. Mônica e Prof. Stefanie, que contribuíram com sugestões valiosas para o encaminhamento dessa pesquisa.

Agradeço ao PPGCOM-USP por ter acreditado e confiado no meu projeto de pesquisa e por ter me apoiado durante toda a pós-graduação.

Agradeço ao CNPq pela bolsa, especialmente em um momento em que a ciência passa por uma crise de descrença causada pela ascensão do pensamento negacionista.

E, claro, agradeço a você, que está lendo essas palavras agora.

Pensei várias vezes em como escreveria esses agradecimentos durante o mestrado. Agora, enquanto reviso a correção da dissertação, vejo que quase nada do que imaginei aconteceu. O que é bom, porque costumava pensar na possibilidade de ocorrer diversas catástrofes pessoais até a entrega desse trabalho. O nome disso? Ansiedade. Mas eu nunca imaginei que passaria por uma pandemia. E, no entanto, sobrevivi. Por isso, agradeço, em especial, aos profissionais de saúde mental que me auxiliaram nessa jornada de autoconhecimento e de aprimoramento profissional.

Sim, você também vai conseguir. Viva um dia de cada vez na pós e dialogue abertamente com o seu orientador. Busque ajuda se precisar e aproxime-se da sua família e dos seus amigos nesse momento. Você não está sozinho. 
"O universo é feito de histórias, não de átomos."

Muriel Rukeyzer, no poema "The Speed of Darkness", 1968

"Como Sherazade e Jesus bem sabiam, contar histórias pode ser um poderoso agente de transformação pessoal"

Janet Murray, O Futuro da Narrativa No Ciberespaço, 1997 
VELLEI, C.S. Os Stories Jornalísticos no Instagram: Investigando os Novos Formatos de Narrativas nas Mídias Sociais. 2020. Dissertação de Mestrado (Programa de Pós-Graduação em Ciências da Comunicação). Escola de Comunicações e Artes - Universidade de São Paulo, São Paulo, 2020.

\section{RESUMO}

Os smartphones se tornaram protagonistas dos fluxos comunicacionais da sociedade e facilitaram a participação das pessoas nas plataformas digitais de mídias sociais. Esse fenômeno serviu de pano de fundo para a criação dos Stories, em 2013, um formato narrativo para dispositivos móveis que oferece a proposta inovadora de autodestruição de suas postagens após 24 horas. Os Stories ganharam projeção a partir de 2016, quando a ferramenta foi implementada no Instagram e, rapidamente, também adotada por outras plataformas digitais. Com a reconfiguração do cenário de mídias, as empresas produtoras de notícias passaram a ter mais um espaço para atuação e a possibilidade de alcançar novos públicos, principalmente os mais jovens que povoam os Stories. Assim, o jornalismo, que também enfrenta crises com o aumento da disseminação de desinformação, é desafiado a superar o anacronismo de suas rotinas de produção para estabelecer um diálogo mais profundo e legítimo com a sua audiência. Com o objetivo de compreender a presença jornalística nos Stories do Instagram, aplicamos no nosso trabalho a metodologia exploratória combinada com a análise de conteúdo nas publicações dos perfis dos jornais Estadão e Folha durante o período de sete dias. Como resultado, desenvolvemos um modelo metodológico para o estudo de publicações no formato Stories e também categorizamos os principais componentes das narrativas jornalísticas nesse ambiente, dividindo-os em elementos narrativos, visuais, interativos, jornalísticos e comerciais. Também constatamos que a construção de stories jornalísticos é simultaneamente influenciada por valores audiovisuais, comerciais, interativos e narrativos presentes na lógica de funcionamento do Instagram. Em nossas discussões teóricas, percebemos que os Stories se destacam pela possibilidade de criar narrativas com percursos não-lineares de navegação através de hiperlinks e etiquetas de metadados, além da oferta de ferramentas de design acessíveis e automatizadas, que potencializam a expressão de emoções e de laços afetivos. Entendemos que, nos Stories, a equalização de vozes estimula a formação de relações mais humanas na prática jornalística e oferece uma conexão direta entre os jornalistas e o público.

Palavras-chave: Jornalismo, Smartphones, Mídias Sociais, Stories, Instagram. 
VELLEI, C.S. Journalistic Stories on Instagram: Investigating New Narrative Formats on Social Media. 2020. Dissertação de Mestrado (Programa de PósGraduação em Ciências da Comunicação). Escola de Comunicações e Artes Universidade de São Paulo, São Paulo, 2020.

\begin{abstract}
Smartphones have become protagonists of society's communication flows and have facilitated people's participation in digital platforms of social media. This phenomenon served as a backdrop for the creation of Stories, in 2013, a narrative format for mobile devices that offers an innovative proposal of self-destruction of the posts after 24 hours. Stories gained projection from 2016, when the format was implemented on Instagram and was also quickly adopted by other digital platforms. With the reconfiguration of the media landscape, news production companies now have more space to act and the possibility of reaching new audiences, especially the younger people who populate the Stories. Thus, journalism, which also faces crises with the increasing dissemination of disinformation, is challenged to overcome the anachronism of its production routines to establish a deeper and more legitimate dialogue with its audience. To understand the journalistic presence in Instagram Stories, in our work we applied the exploratory methodology combined with content analysis in the publications made by the newspapers Estadão and Folha during a seven-day period. As a result, we developed a methodological model for the study of publications in Stories format and, also, we have categorized the main components of journalistic narratives in this environment, dividing them into narrative, visual, interactive, journalistic, and commercial elements. We also found that the construction of journalistic stories is simultaneously influenced by audiovisual, commercial, interactive, and narrative values present in the logic of Instagram's operation. In our theoretical discussions, we noticed that Stories stand out for the possibility of creating narratives with non-linear navigation paths through hyperlinks and metadata tags, in addition to offering accessible and automated design tools, which enhance the expression of emotions and affection ties. We understand that, in Stories, the equalization of voices encourages the formation of more human relations in journalistic practice and offers a direct connection between journalists and the public.
\end{abstract}

Keywords: Journalism, Smartphones, Social Media, Stories, Instagram. 


\section{LISTA DE FIGURAS}

\section{Capítulo 1}

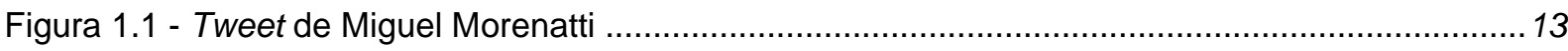

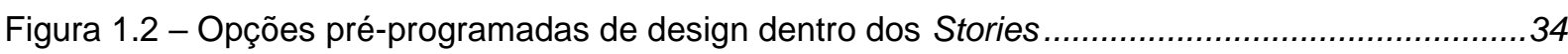

Figura 1.3 - Cenas do momento em que o repórter Alex Zdan reage à atitude do eleitor de Trump ...40

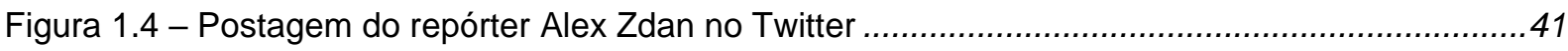

Figura 1.5 - Publicações no Twitter em defesa do jornalista Alex Zdan ............................................42

Figura 1.6 - Donald Trump alega vitória nas eleições de 2020. As publicações foram marcadas pelo

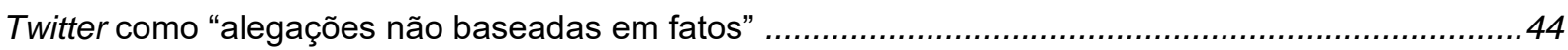

Figura 1.7 - Frequência do uso da palavra pós-verdade na Internet ..................................................48

Figuras 1.8 e 1.9 - Stories com informações sobre o coronavírus.....................................................50

Figuras 1.10 e 1.11 - Cobertura nos stories da Folha de operação da Polícia Federal .......................55

Figuras 1.12, 1.13 e 1.14 - Cobertura nos stories do Estadão de operação da Polícia Federal ..........55

Figura 1.15 - Story do Estadão desmentindo fake news envolvendo Felipe Neto ..............................56

Figura 1.16 - Exemplo de captura de tela do iPad com reprodução de story do Estadão.....................65

Figura 1.17 - Exemplo de captura de tela do iPad com reprodução de story da Folha de S. Paulo ...66

\section{Capítulo 2}

Figura 2.1 - Levantamento da MOM-Brasil que mostra as principais empresas do Grupo Estado .......77

Figura 2.2 - Levantamento da MOM-Brasil que mostra as principais empresas do Grupo Folha..........79

Figura 2.3 - Distribuição semanal dos stories no perfil do Estadão no Instagram ................................80

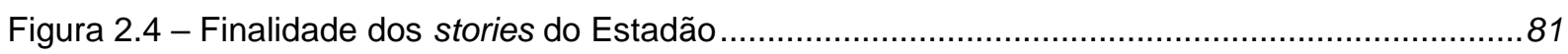

Figura 2.5 - Distribuição temática dos stories (jornalismo e branded content) ……............................82

Figura 2.6 - Percentual de stories diários das temáticas mais postadas no Estadão............................82

Figura 2.7 - Recorrência de palavras-chave nos textos dos stories do Estadão ...................................83

Figura 2.8 e 2.9 - Tipos de layout presentes nos Stories do Estadão .............................................. 84

Figura 2.10 e 2.11 - Texto do Instagram semelhante ao texto do site do Estadão ..............................86

Figura 2.12 - Percentual de hiperlinks nos stories do Estadão (total semanal) .................................87

Figura 2.13 - Gráfico de distribuição semanal dos stories da Folha ................................................8

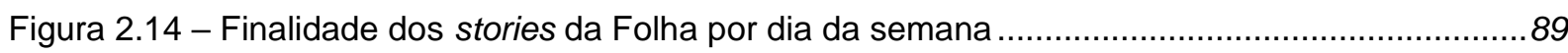

Figura 2.15 - Distribuição temática dos stories (jornalismo e branded content) da Folha ......................90

Figura 2.16 - Percentual de stories diários das temáticas mais postadas na Folha ............................90

Figura 2.17 - Recorrência de palavras-chave nos textos dos stories da Folha ...................................91

Figura 2.18, 2.19 e 2.20 - Tipos de layout presentes nos stories da Folha .......................................92

Figura 2.21 - Percentual de hiperlinks nos stories da Folha (total semanal) ....................................94

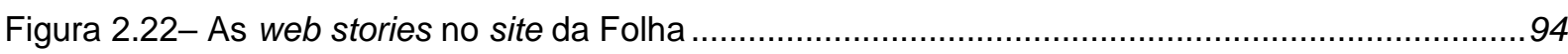

Figura 2.23 - Texto do Instagram semelhante ao texto do site da Folha............................................95

Figura 2.24 - Breve panorama da coleta de stories dos jornais......................................................96 


\section{Capítulo 3}

Figura 3.1 - Representação dos valores estruturantes dos stories jornalísticos ...............................108

Figura 3.2 - Exemplo de etiquetas de interação disponíveis para personalização dos stories ..........113

Figuras 3.3 e 3.4 - Uso do recurso Perguntas para interação com a audiência ...............................114

Figuras 3.5, 3.6 e 3.7 - Uso da Enquete para interação com a audiência .......................................... 114

Figuras 3.8, 3.9 e 3.10 - Uso da Contagem Regressiva para interação com a audiência ................115

Figuras 3.11 e 3.12 - Uso da função Mensagem Direta (DM) para interação com a audiência ..........116

Figuras 3.13, 3.14 e 3.15 - Stories sobre as manifestações do movimento Black Lives Matter ........119

Figura 3.16, 3.17, 3.18 e 3.19 - Exemplos de usos do paywall e de anúncios de assinatura ...........122

Fig. 3.20, 3.21, 3.22 e 3.23 - E-Investidor nos stories e no site do Estadão .....................................123

Fig. 3.24 e 3.25 - Eventos patrocinados nos stories do Estadão ……..........................................123

Fig. 3.26, 3.37 e 3.28 - Coleções Folha nos stories do jornal ....................................................... 124

Figura 3.29 e 3.30 - Monetização de podcasts divulgados nos stories ..........................................125

Figura 3.31, 3.32 e 3.33 - Divulgação de postagens patrocinadas nos Stories ................................126

Figura 3.34, 3.5 e 3.36 - Parceria com a Cielo com uso de filtro de realidade aumentada ................127

Figura 3.37 - Menção nos stories do @estadao do perfil de @murilobusolin, criador do Drops e, ao lado, duas capturas de tela que mostram o perfil do jornalista sem (parte superior) e com (parte inferior) o selo de autenticidade do Instagram

Figura 3.38 - Menção nos stories do @estadao do perfil de @joaoabel_, editor do Drops e, ao lado, duas capturas de tela que mostram o perfil do jornalista sem (parte superior) e com (parte inferior) o selo de autenticidade do Instagram 130

Figura 3.39 - Menção nos stories do @estadao do perfil de @barbara_pereira, apresentadora do Drops e, ao lado, duas capturas de tela que mostram o perfil da jornalista sem (parte superior) e com (parte

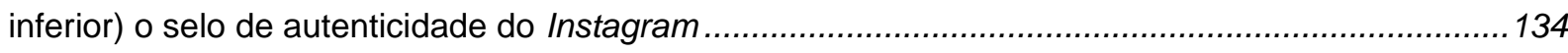

Figura 3.40 - Participação de influenciadores digitais nos Stories do Estadão .................................135

Figuras 3.41 e 3.42 - Exemplos de soft news ligadas ao infotenimento nos Stories dos jornais ....... 136

Figuras 3.43 e 3.44 - Exemplos de soft news ligadas à cultura dos fãs .........................................136

Figuras 3.45 e 3.46 - Exemplos de soft news ligadas à cultura pop...............................................137

Figuras 3.46 a 3.50 - Receita de bolo de cenoura publicada originalmente no perfil pessoal da jornalista @barbara_pereira e republicada pelo perfil oficial do Estadão ..................................................... 138

Figura 3.51 - Exaltação emocional no rosto de Bolsonaro acrescenta informação ao texto ..............141

Figura 3.52 - Cenas da Operação Placebo com começo, meio e fim..............................................142 


\section{LISTA DE QUADROS}

\section{Capítulo 1}

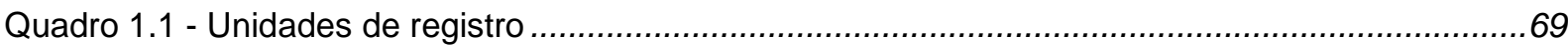

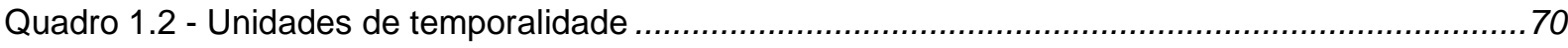

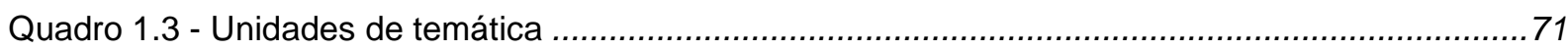

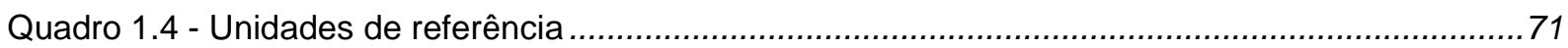

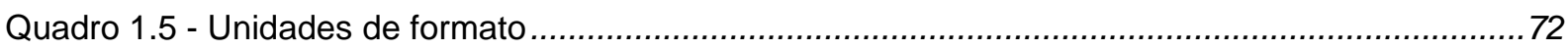

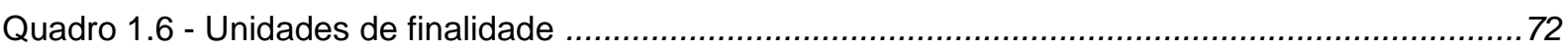

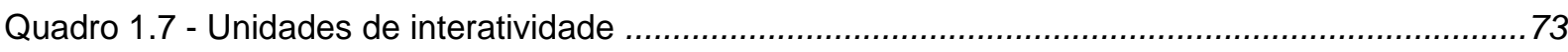

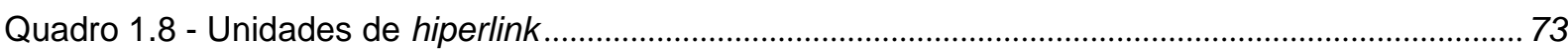

\section{Capítulo 2}

Quadro 2.1 - Objetivos de cada campo de análise para o estudo de stories, definidos a partir das unidades de contexto, e sua aplicação a partir de perguntas-chave........................................................ 102

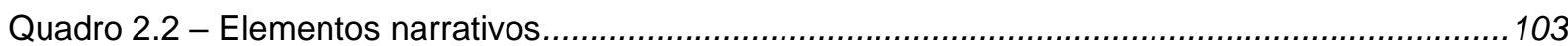

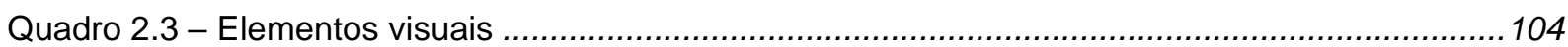

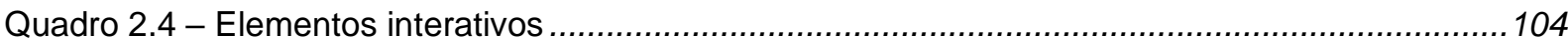

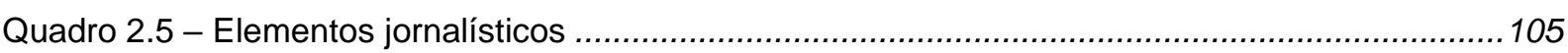

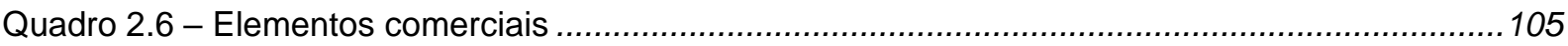

\section{Capítulo 3}

Quadro 3.1 - Divisão em categorias dos elementos que compõem os stories jornalísticos a partir de suas funções

Quadro 3.2 - Valores dos Stories do Instagram, suas características e suas influências sobre os stories jornalísticos 


\section{SUMÁRIO}

INTRODUÇÃO

1 TODO MUNDO TEM UMA HISTÓRIA PARA CONTAR (E PARA MOSTRAR) ..........................................................2

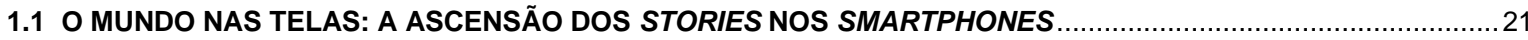

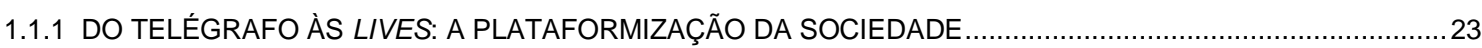

1.1.2 CONTAÇÃO DE STORIES: AS NARRATIVAS COM DATA DE VALIDADE ....................................................28

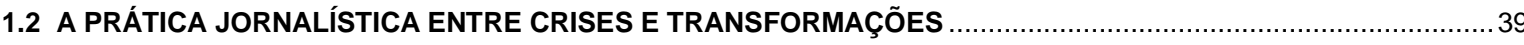

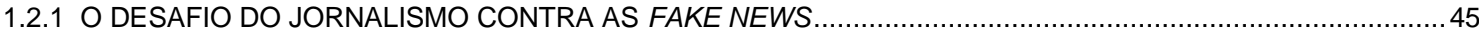

1.2.2 REINVENTANDO AS FORMAS DE PRODUZIR E DE CONSUMIR NOTÍCIAS..............................................52

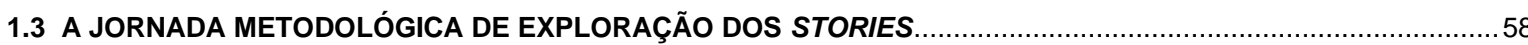

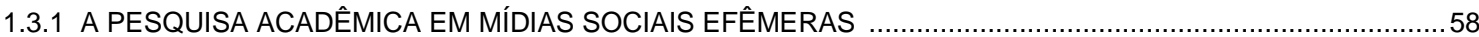

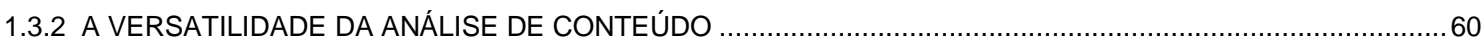

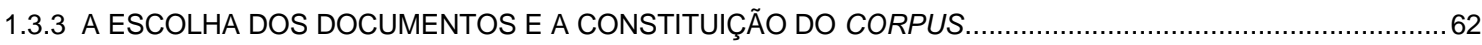

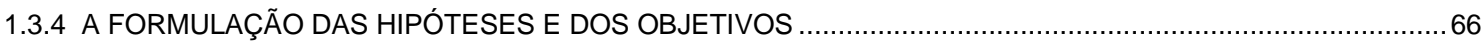

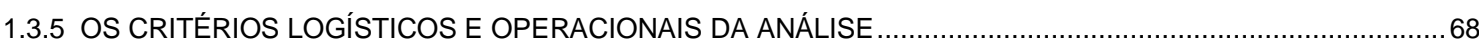

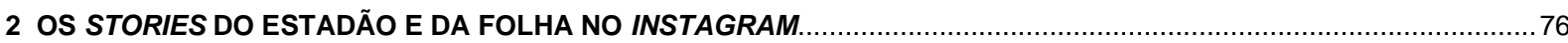

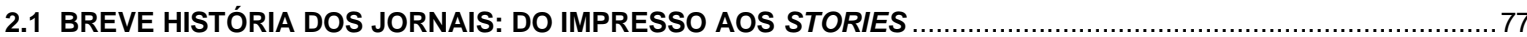

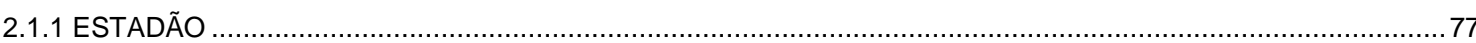

2.1.2 FOLHA

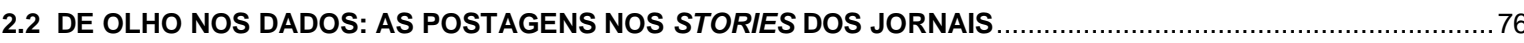

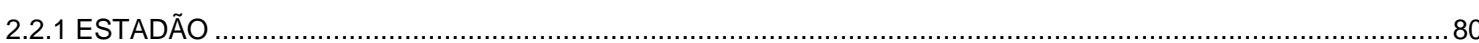

2.2.2 FOLHA ……

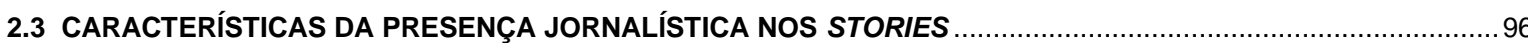

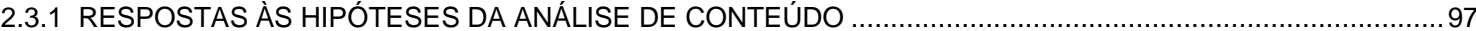

2.3.2 AS CATEGORIAS DE ELEMENTOS NA ESTRUTURA DOS STORIES ..................................................... 101

3 A INFLUÊNCIA DE VALORES DOS STORIES DO INSTAGRAM NOS STORIES JORNALÍSTICOS .............................. 106

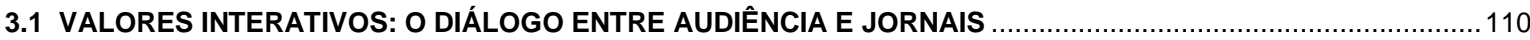

3.1.1 AS FERRAMENTAS DE INTERAÇÃO DENTRO DOS STORIES .......................................................111

3.1.2 O USO DE ETIQUETAS DE METADADOS NO INSTAGRAM ............................................................. 116

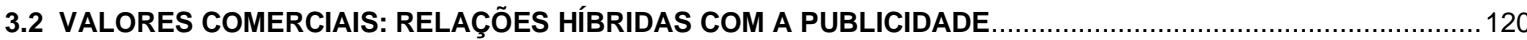

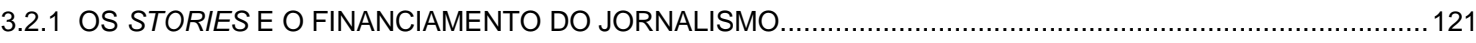

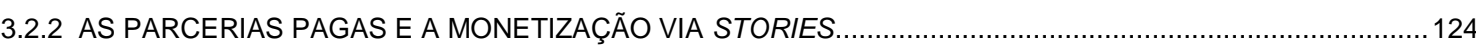

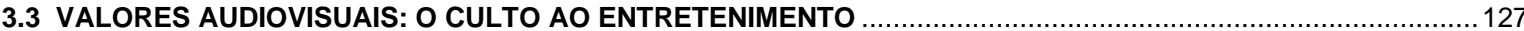

3.3.1 O JORNALISMO SELFIE NO MUNDO DOS INFLUENCIADORES DIGITAIS ............................................ 132

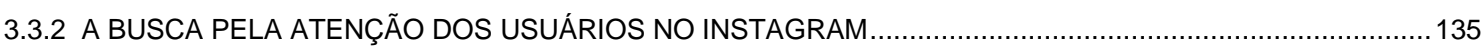

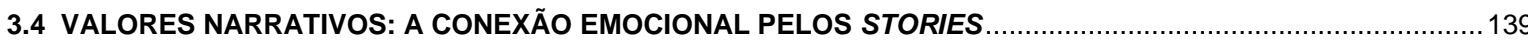

3.4.1 O PAPEL DO DESIGN NOS STORIES PARA A ATIVAÇÃO DE EMOÇÕES ........................................... 143

3.4.2 OS STORIES COMO PORTA PARA UM OLHAR MAIS HUMANO NA PRÁTICA JORNALÍSTICA ...................145

CONCLUSÃO

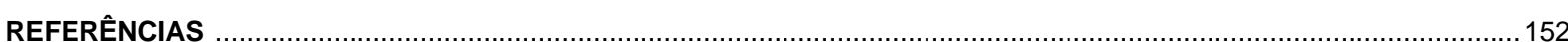

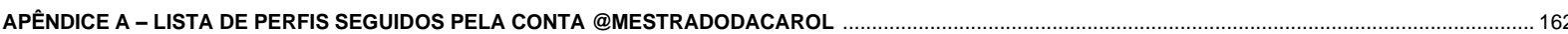

APÊNDICE B - PANORAMA NUMÉRICO DA ANÁLISE DO ESTADÃO

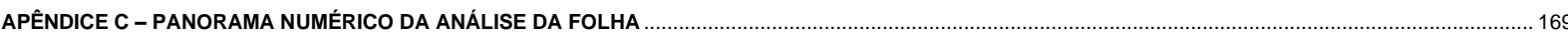

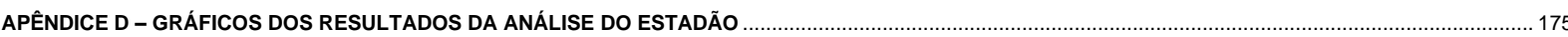

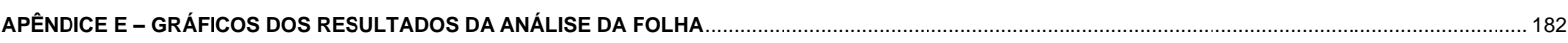




\section{INTRODUÇÃO}

Em 2015, uma foto tirada na estreia de um filme norte-americano se espalhou nas redes sociais online por um motivo inusitado (figura 1.1). Na plateia de fãs aguardando a passagem dos atores pelo tapete vermelho, uma senhora contrastava na multidão. Apoiada sobre a grade de proteção, era a única que não registrava o evento com a câmera de um celular.

Depois de publicado no jornal Boston Globe, o clique foi parar no reddit ${ }^{1} \mathrm{com}$ o título "a diferença entre gerações" (REDDIT, 2015), onde se alastrou por toda a Internet. Na plataforma digital Twitter, o fotógrafo Miguel Morenatti postou a imagem com a legenda "Estamos perdendo a capacidade de desfrutar dos momentos importantes" e recebeu mais de 23 mil retweets:

\section{Figura 1.1 - Tweet de Miguel Morenatti}

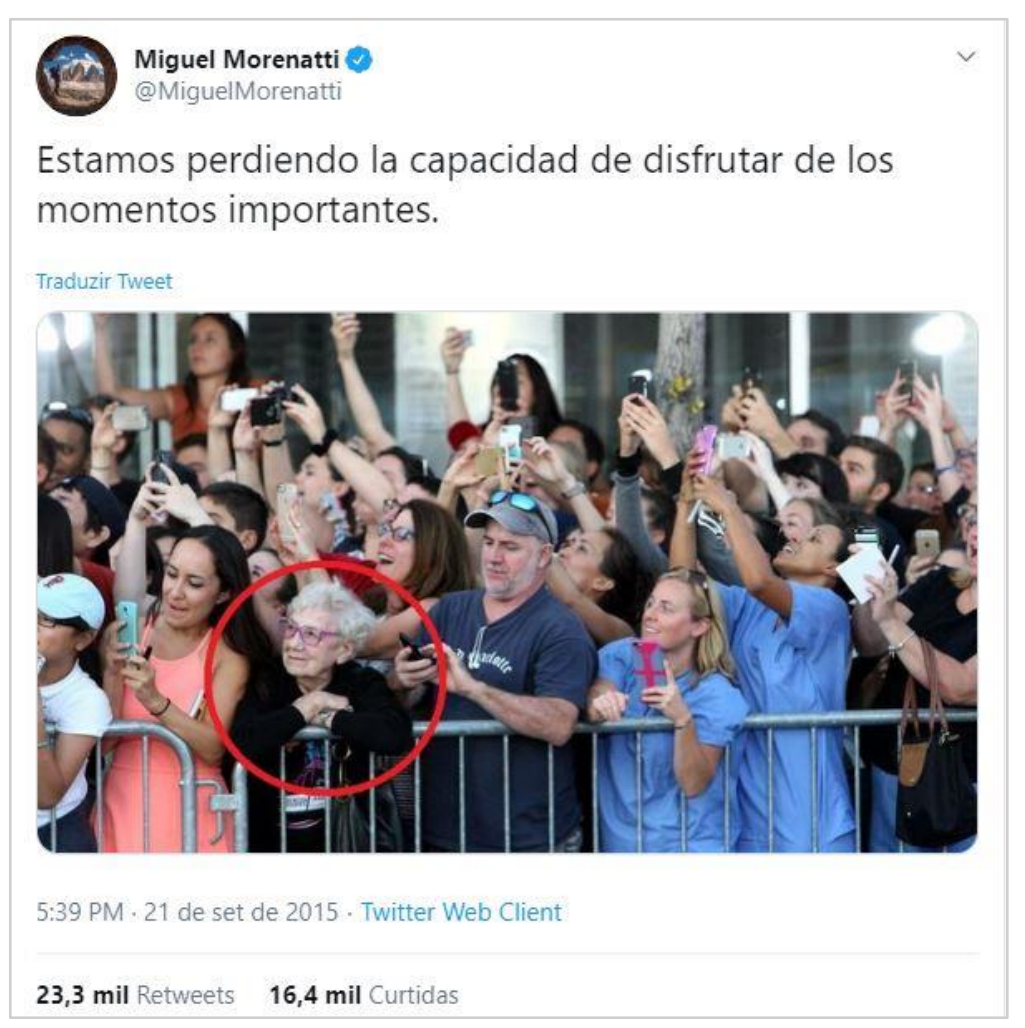

Foto: captura de tela da autora (2019) / reprodução via Twitter

\footnotetext{
$1 \mathrm{O}$ reddit é uma site de rede social que funciona como um fórum, em que os usuários podem votar em conteúdos mais relevantes e fazer comentários.

2 Dentro do Twitter, a palavra retweet é utilizada para indicar o compartilhamento de uma postagem (conhecida como tweet) por outros usuários.
} 
A senhora da foto, Betty Sushman, faleceu em 2018. Naquele ano, o site de onde se originou a foto decidiu fazer uma homenagem póstuma em seu nome. $\mathrm{Na}$ reportagem, o fotógrafo John Blanding, responsável pelo clique, foi entrevistado e contou que a imagem foi um "total acidente" e que ele não tinha notado a idosa e não imaginava que a foto fosse ficar famosa por esse motivo (GARTSBEYN, 2018, online).

A imagem, que desde 2015 circula pela Internet, voltou a viralizar em 2018 após ser postada no Facebook com a legenda: "A mais profunda foto que eu vejo em muito tempo. Viva o momento", com mais de 380 mil compartilhamentos e 290 mil curtidas (MARITZ, 2018, online). A reflexão sobre a necessidade de viver o presente sem o intermédio da tecnologia fez sucesso entre as pessoas. A grande ironia é que, muito provavelmente, as pessoas que repostaram a foto fizeram isso diretamente de um smartphone.

Smartphones, mídias sociais, big data e privacidade: o nascimento dos Stories e o seu uso no campo jornalístico

Para entender as motivações que nos levaram ao presente trabalho, é necessário, antes, contextualizar um importante personagem da nossa história. A centralidade dos smartphones na sociedade é percebida não apenas por histórias como a da foto que abriu essa introdução, mas, principalmente, por pesquisas sobre hábitos de navegação na Internet. Mais de 90\% dos usuários que acessam a Internet através de dispositivos móveis o fazem utilizando um smartphone, o equivalente a 3,8 bilhões de pessoas. Se ampliarmos para toda as categorias de dispositivos móveis, esse número sobe para 4,18 bilhões (WE ARE SOCIAL, 2020).

Como resultado, o aumento da circulação de imagens e de informações contribuiu para o crescimento do volume de dados pessoais disponíveis na Internet. No contexto de uma economia que enxerga grande valor no big data ${ }^{3}$ (COULDRY; MEJIAS, 2019) essas informações passaram a ser comercializadas por grandes empresas de tecnologia, despertando dilemas éticos e a preocupação da sociedade com relação à privacidade das pessoas.

Uma alternativa para lidar com o excesso de informações e os problemas relativos ao armazenamento de publicações pessoais na Internet surge com as mídias sociais efêmeras (BAYER et al, 2016). A expressão começou a ser usada por

${ }^{3}$ Big data é uma expressão em inglês usada para se referir a grandes volumes de dados. 
pesquisadores da área da comunicação a partir da criação do Snapchat, em 2011, uma plataforma digital de comunicação para smartphones que inovou ao permitir a autodestruição automática de imagens e mensagens trocadas por seus usuários após um período de tempo pré-estabelecido de até 10 segundos.

Em 2013, depois de uma longa tradição de arquivos permanentes na Internet, ocorre um importante capítulo na história das mídias sociais. Dando mais um passo à frente dos demais concorrentes, o Snapchat criou os Stories, um formato inédito de mídia social efêmera que permite aos usuários organizarem fotos e vídeos de até 10 segundos de duração em uma sequência cronológica temporária. Com forte apelo narrativo e direcionado para o compartilhamento de momentos divertidos e espontâneos do dia a dia das pessoas, as publicações ficam disponíveis para a lista de amigos do usuário por até 24 horas. Valorizando experiências no tempo presente, após esse período, elas são deletadas pela plataforma, dando espaço para a criação de novas postagens, diariamente.

Em 2016, após tentar comprar o Snapchat e não obter sucesso no negócio, o Grupo Facebook decidiu implementar em seu aplicativo Instagram uma função muito semelhante ao Snapchat Stories. Devido ao seu sucesso, os Stories do Instagram se tornaram uma importante vitrine para as empresas alcançarem seus consumidores, principalmente os mais jovens, que compõem cerca de $70 \%$ dos usuários da plataforma 4 . Hoje, mais do que nunca, os jovens são vistos como pioneiros que revelam tendências para o futuro das comunicações (SANTAELLA, 2015).

Em paralelo ao fenômeno dos Stories, o mercado de notícias também passa por reconfigurações. O jornalismo enfrenta diversas crises, não apenas financeiras, mas também de confiança, com quedas de arrecadação e com uma luta cada vez mais difícil contra a desinformação alavancada pelas fake news. A multiplicidade de competências do jornalista, que já era uma necessidade da profissão em um contexto de jornalismo ubíquo (SILVEIRA, 2017), passa a ter ainda mais protagonismo quando enxergamos o ambiente comunicacional como uma rede complexa de interações sistêmicas. Isso nos abre a possibilidade de também compreender a narrativa jornalística digital como sistema narrativo (BERTOCCHI, 2016).

\footnotetext{
${ }^{4}$ Esse número corresponde à faixa etária de 13 a 34 anos. Para ver a distribuição completa dos dados demográficos do Instagram: https://www.statista.com/statistics/325587/instagram-global-age-group/
} 
Para Bertocchi (2016), o sistema narrativo ressalta a urgência de se pensar a narrativa jornalística para além do agenciamento dos fatos, ou seja, para além do produto jornalístico publicado como etapa final. Não mais linear, o processo passa a ser visto de forma circular, valorizando formatos adaptativos de conteúdo jornalístico em uma constante relação "forma-conteúdo-tela".

Em busca de novas fontes de renda e de audiência, as empresas de comunicação experimentam os Stories do Instagram, reinventando diariamente o fazer jornalístico dentro da plataforma. Tais mudanças despertam o interesse acadêmico a fim de entender as estratégias dos veículos de notícias nesse novo ambiente de construção e de distribuição de conteúdo.

\section{Os objetivos dessa pesquisa}

O nosso estudo teve como objetivo principal oferecer um panorama da presença jornalística nos Stories do Instagram, como uma forma de contribuir para a ampliação dos estudos nesse recente campo midiático. Abaixo, detalhamos as demais motivações para a nossa pesquisa:

Objetivo Geral: refletir sobre a produção de stories em mídias sociais efêmeras e descrever como o formato pode ser usado para a prática jornalística.

Objetivos Específicos: caracterizar as mídias sociais efêmeras, localizandoas dentro do campo das plataformas digitais de mídias sociais; depreender do ambiente dos Stories as características da presença jornalística nos conteúdos veiculados; descrever como a interface e os elementos gráficos das mídias sociais efêmeras contribuem para a construção das narrativas jornalísticas.

Objetivos Teóricos: realizar estudos bibliográficos sobre a contemporaneidade, destacando seus aspectos comunicacionais e imagéticos transversais a essa pesquisa, a fim de contribuir para formação de um campo teórico sobre o jornalismo em mídias sociais efêmeras.

Objetivos Práticos: coletar e analisar stories oriundos de perfis jornalísticos brasileiros a partir de uma metodologia exploratória de análise de conteúdo.

\section{A metodologia utilizada para esse estudo}

Levando em conta o panorama das pesquisas nacionais e internacionais feitas durante o período de aproximação ao nosso objeto, percebemos que o formato 
Stories ainda não foi amplamente explorado no meio acadêmico, diferentemente de estudos realizados, por exemplo, em outras mídias mais consolidadas, como o rádio e a televisão, que já contam com metodologias testadas e replicadas.

O próprio Instagram, como aplicativo para smartphones, completou dez anos em outubro de 2020. Ao focar a nossa pesquisa na observação do uso dos Stories pelas empresas jornalísticas, ainda adicionamos o fato de que as grandes empresas jornalísticas brasileiros passam a dar atenção a esse formato apenas no final de 2016, depois de o Instagram e de outras plataformas adotarem as mídias sociais efêmeras (BAYER et al, 2016) em suas estruturas.

Em busca de uma metodologia que desse conta da complexidade do nosso objeto, optamos por uma abordagem exploratória, utilizando como instrumento a análise de conteúdo, a partir da sistematização proposta pela pesquisadora Laurence Bardin (2016). Adaptamos essa ferramenta metodológica para o estudo de publicações no formato Stories e aplicamos essa formulação em uma amostra de stories produzidos por empresas jornalísticas. A coleta foi realizada durante sete dias, diretamente do perfil no Instagram do Estadão e da Folha, escolhidos por serem jornais com atuações semelhantes e por publicarem stories regularmente. A metodologia é detalhada em profundidade no primeiro capítulo.

\section{Breve apresentação dos capítulos}

No primeiro capítulo, contextualizamos teoricamente o atual momento vivido pela comunicação. Abordamos a importância das telas nas nossas vidas, o fortalecimento dos smartphones, o crescimento de poder das plataformas digitais, o papel das narrativas no cotidiano das pessoas e o surgimento das mídias sociais efêmeras. Também no primeiro capítulo, discutimos a crise jornalística e as novas formas de consumir notícias. Por último, encerramos o capítulo com uma descrição detalhada da nossa metodologia. Observando os campos de análise da estrutura dos Stories, desenvolvemos um modelo de investigação para publicações nesse formato a partir de perguntas-chave sobre a amostra coletada, com base na sistematização de análise de conteúdo proposta por Bardin (2016).

O segundo capítulo explora o mergulho nos dados obtidos através da descrição e da análise das amostras de stories do Estadão e da Folha, durante a semana de 25 a 31 de maio de 2020. Iniciamos o capítulo com um breve histórico de 
cada empresas e, em seguida, expomos os dados numéricos da análise de conteúdo de cada perfil. Finalizamos a parte empírica com uma análise qualitativa dos resultados, organizando os elementos estruturais dos stories jornalísticos em categorias: elementos narrativos, elementos visuais, elementos interativos, elementos jornalísticos e elementos comerciais.

Após a categorização dos elementos constituintes das narrativas jornalísticas dentro dos Stories, descreveremos, no terceiro capítulo, a influência de aspectos intrínsecos à própria plataforma para a construção dos stories jornalísticos. São características muitas vezes relacionadas à construção algorítmica do Instagram e que oferecem configurações variáveis para a relação entre plataforma, produtor e audiência: valores interativos, comerciais, audiovisuais e narrativos. Esses valores serão descritos em profundidade, com discussões teóricas sobre o campo jornalístico e as mídias sociais.

\section{A influência da COVID-19 no nosso trabalho}

Com a intensa convergência vivida pela sociedade, seria difícil não nos referirmos ao vírus que parou o planeta em 2020 enquanto fazíamos nossa pesquisa. A pandemia da COVID-19 causou mudanças em praticamente todas as áreas da vida das pessoas. Como os leitores desse trabalho poderão perceber, os capítulos da nossa dissertação refletem aspectos dessas mudanças globais.

Em março de 2020, a nossa pesquisa se direcionava para o momento de coleta de amostras quando o Governo Estadual decretou quarentena em São Paulo. Ainda sem termos dimensão das consequências trágicas que a pandemia traria ao mundo ou do tempo que demoraria para passar, decidimos adiar a nossa coleta, visto que todo o ecossistema de jornalismo sofreu alterações com a cobertura intensiva sobre o novo coronavírus. Em maio de 2020 e ainda em quarentena, optamos por aceitar que o cenário faria parte de nossa análise e retomamos a pesquisa, explorando e descrevendo as publicações nos Stories da Folha e do Estadão, as duas empresas de jornalismo escolhidas para compor nossas amostras.

Por conta disso, no capítulo introdutório traremos adicionalmente dados sobre a transformação no consumo de mídias sociais durante o período de quarentena durante a pandemia e também sobre o aumento da disseminação de desinformação, fenômenos que influenciaram diretamente a produção de stories no período analisado. 
Já no segundo capítulo, veremos os impactos da cobertura jornalística sobre o coronavírus e a predominância do assunto nas temáticas das amostras de stories do Estadão e da Folha. As discussões realizadas no terceiro capítulo também foram influenciadas pela remodelação da produção de Stories como, por exemplo, com jornalistas mudando do cenário das redações para o ambiente doméstico de seus lares.

\section{Algumas observações conceituais}

Antes de prosseguirmos para os capítulos, cabe esclarecer que, cientes da variedade de conceitos acadêmicos que existem para definir as redes sociais online, adotamos em nossa pesquisa o conceito de mídias sociais a partir de danah boyd ${ }^{5}$ (2014) para padronizar as referências a esses ambientes e a outros correlatos. A pesquisadora de comunicação digital emprega a expressão para se referir, de forma geral, a sites e a serviços criados a partir dos anos 2000, incluindo sites de redes sociais, sites de compartilhamento de vídeos, plataformas de blogs e microblogging e ferramentas afins, que permitem que os participantes possam criar e compartilhar seu próprio conteúdo (BOYD, 2014).

Também destacamos que, assim como no Twitter, plataforma digital em que cada postagem é conhecida como tweet, com inicial minúscula, optamos pelo uso da palavra story ou stories com o $s$ minúsculo quando estivermos citando uma publicação específica ou mais dentro dos perfis analisados. Já Stories, com a letra $S$ maiúscula, será adotado para nos referirmos ao formato, que foi originalmente inaugurado em 2013 pelo Snapchat e adaptado em 2016 pelo Instagram.

Por fim, é preciso dizer que esse tipo de mídia sofreu uma drástica mudança quando o Snapchat adicionou a função Memórias ao seu aplicativo para smartphones, em 2016. O recurso possibilitou, a partir disso, o arquivamento privado de todas as fotografias e vídeos compartilhados pelo usuário. No final de 2017 foi a vez do Instagram, que criou a função Destaque e Arquivo para o gerenciamento de postagens nos Stories. Portanto, ressaltamos que o apagamento padrão após 24 horas das chamadas mídias sociais efêmeras (BAYER et al, 2016) se limita apenas à sua disponibilidade para a audiência e não mais ao produtor do conteúdo.

\footnotetext{
${ }^{5}$ A própria pesquisadora assina seu nome com letras minúsculas por uma decisão pessoal e política. Disponível em: http://www.danah.org/name.html
} 


\title{
1 TODO MUNDO TEM UMA HISTÓRIA PARA CONTAR (E PARA MOSTRAR)
}

Os Stories do Instagram são um formato de visualização de mídia que oferece opções de construção, publicação, interação e organização de informações em uma sequência de imagens que, juntas, possuem potencial narrativo. Como explica a pesquisadora de narrativas interativas, Janet H. Murray (2003), a narrativa é uma das principais maneiras pelas quais o ser humano organiza o mundo através dos seus muitos milênios de evolução. A narrativa é "também um dos modos fundamentais pelos quais construímos comunidades [...]. Nós nos compreendemos mutuamente através dessas histórias, e muitas vezes vivemos ou morremos pela força que elas possuem" (MURRAY, 2003, p. 9).

Outra razão para o grande sucesso dos Stories, além da nossa inata vontade de narrar, é que "as histórias que são contadas em formatos participativos nos envolvem de uma maneira diferente daquelas às quais assistimos ou ouvimos" (MURRAY, 2003, p. 3). Sendo assim, as múltiplas potencialidades das mídias sociais e, principalmente, os elementos narrativos e interativos apresentados pelos Stories, oferecem um rico campo de possibilidades não apenas para os usuários comuns da plataforma, como também para as empresas de jornalismo.

O fazer narrativo está no cerne do jornalismo, especialmente se considerarmos que as narrativas jornalísticas ${ }^{6}$ são estórias ${ }^{7}$ sobre 0 mundo real contadas por jornalistas (BERTOCCHI, 2006, p. 126), o que faz do jornalismo uma profissão essencialmente especializada em contar histórias.

\begin{abstract}
A convicção de que o "real" pode ser transmitido "sem linguagem" contribui para o afastamento do termo "narrativa" ao da "notícia", como se fossem duas coisas distintas, e que se anulam devido à ficcionalidade da narrativa e à realidade da notícia. [...] queremos assumir que "narrar um acontecimento" não é o mesmo que o próprio "acontecimento". Significa dizer, deste modo, que as narrativas jornalísticas, as notícias e as reportagens, podem ser entendidas como "estórias". (BERTOCCHI, 2006, p. 107-109).
\end{abstract}

Conscientes do papel das imagens e das telas como suporte das narrativas, buscamos, a seguir, contextualizar as discussões que desenvolveremos ao longo desse trabalho, abordando temas da tecnologia digital móvel, das novas estratégias de atuação do jornalismo e do universo dos Stories.

\footnotetext{
${ }^{6}$ Seguindo o entendimento de Bertocchi (2006), no nosso trabalho as narrativas jornalísticas dizem respeito principalmente ao que conhecemos tradicionalmente como notícia e reportagem.

${ }^{7}$ Entendemos a palavra "histórias" como sinônimo de estórias.
} 


\subsection{O MUNDO NAS TELAS: A ASCENSÃO DOS STORIES NOS SMARTPHONES}

O seriado inglês Black Mirror impactou o mundo com distopias em que a humanidade leva a tecnologia a situações extremas, questionando valores morais e aspectos éticos de seu uso. O criador da série, Charlie Brooker, escolheu o título em alusão ao "espelho negro" que surge ao desligarmos uma tela eletrônica, no qual é possível enxergar nosso reflexo. "O espelho negro do título é aquele que você vai encontrar em cada parede, em cada mesa, na palma da sua mão todos os dias: a fria e brilhante tela de uma TV, um monitor, um smartphone“ (BROOKER, 2011, online, tradução nossa9).

O fato de essa superfície se quebrar na abertura do seriado se justifica pelo modo como as histórias são conduzidas: todas questionam a forma como a humanidade se relaciona com a tecnologia e, em especial, as que transportam imagens. De fato, as telas (e a representação dos mundos internos e externos das pessoas, de forma geral) têm atraído a atenção do ser humano há milênios, de modo que é praticamente impossível datar o momento em que nossos ancestrais foram fisgados pelo poder das imagens.

Em uma caminhada histórica que se acelerou durante o século $X X$, as telas foram ocupando uma relevância cada vez maior como suporte imagético para as relações do ser humano com o mundo, com os outros indivíduos e com si próprio. Dentro dessa história, o ano de 2007 foi marcado pelo nascimento do dispositivo móvel que começaria uma revolução não apenas nas comunicações, mas na vida das pessoas como um todo: o iPhone, considerado pela Revista Time como o aparelho mais influente de todos os tempos.

Os smartphones existiam tecnicamente há anos, mas nenhum de forma tão acessível e bela quanto o iPhone. O dispositivo da Apple inaugurou uma nova era de telefones planos e touchscreen com botões que apareciam na tela quando você precisava, substituindo os telefones mais volumosos com teclados deslizantes e botões estáticos. O que realmente tornou o iPhone tão notável, no entanto, foi seu software e loja de aplicativos móveis, introduzidos mais tarde. O iPhone popularizou o aplicativo móvel, mudando para sempre a forma como nos comunicamos, jogamos jogos, compramos, trabalhamos e

\footnotetext{
8 Seriado televisivo originalmente exibido pelo Channel 4, no Reino Unido, e depois adquirido pela Netflix, serviço de vídeos sob demanda, de 2011 a 2019.

9 "The 'black mirror' of the title is the one you'll find on every wall, on every desk, in the palm of every hand: the cold, shiny screen of a TV, a monitor, a smartphone".
} 
completamos muitas tarefas cotidianas. (TIME, 2016, online, tradução nossa ${ }^{10}$ )

Com um papel central na sociedade graças à unificação de funções que anteriormente demandavam inúmeros equipamentos diferentes, o iPhone mudou a forma como o mundo se relacionaria nos anos futuros com displays sensíveis ao toque, com a produção e o consumo de imagens e com a comunicação em rede.

A tela, portanto, é a parte visível da tecnologia, a camada exterior que funciona como uma linha divisória entre a nossa interação e os circuitos elétricos que compõem o interior dos hardwares. A tela apresentada aos usuários de smartphones - e computadores, no geral - faz com que as pessoas enxerguem apenas a ponta do iceberg das relações midiáticas. No ambiente amigável criado por designers de experiência e desenvolvedores de sistemas, inúmeros códigos binários são executados. Por trás da superfície das telas, esse fenômeno muito mais complexo nos mostra o quanto ainda estamos longe do entendimento do que o "black mirror" pode significar nas nossas vidas.

Na década de 1980, o filósofo Vilém Flusser utilizou o conceito de caixa-preta (FLUSSER, 2018) como metáfora para explicar o modo como a técnica fotográfica transformou a nossa relação com a produção imagética e com a tecnologia em geral. A expressão caixa-preta é empregada por ele para caracterizar sistemas complexos que não são totalmente compreendidos, os quais Flusser chama de aparelhos:

\begin{abstract}
O aparelho funciona, efetiva e curiosamente, em função da intensão do fotógrafo. Isso porque o fotógrafo domina o input e o output da caixa: sabe com que alimentá-la e como fazer para que ela cuspa fotografias. Domina o aparelho, sem, no entanto, saber o que se passa no interior da caixa. Pelo domínio do input e do output, o fotógrafo domina o aparelho, mas, pela ignorância dos processos no interior da caixa, é por ele dominado. (FLUSSER, 2018, p. 36)
\end{abstract}

A facilidade para registrar um fragmento visível da realidade com uma máquina fotográfica pode causar encanto e espanto, visto que o "aparelho deve ser impenetrável para o fotógrafo, em sua totalidade" (FLUSSER, 2018, p. 36). Isso desperta emoções que engajam o usuário na atividade de modo a repeti-la inúmeras

10 "Smartphones had technically existed for years, but none came together as accessibly and beautifully as the iPhone. Apple's device ushered in a new era of flat, touchscreen phones with buttons that appeared on screen as you needed them, replacing the chunkier phones with slide-out keyboards and static buttons. What really made the iPhone so remarkable, however, was its software and mobile app store, introduced later. The iPhone popularized the mobile app, forever changing how we communicate, play games, shop, work, and complete many everyday tasks." 
vezes sem muita complexidade ou reflexão. Também é assim ao usarmos os smartphones: apertamos um botão, tocamos a tela, deslizamos os dedos e a aparente mágica se faz. Diversos bits conversam entre si, sem que necessitemos fazer um só cálculo matemático. Para Arlindo Machado (2001), essa relação dos homens com as máquinas possui características de fetiche, principalmente pelo esforço dos fabricantes para que os equipamentos eletrônicos se tornem cada vez mais atraentes e sedutores aos consumidores. "As pessoas se deliciam (ou até mesmo se viciam) apertando botões compulsivamente, enquanto observam os resultados em termos de movimentos mirabolantes numa tela de monitor e essa simples atividade já é suficiente para entretê-las" (MACHADO, 2001, p. 13).

A popularização dos smartphones e o avanço das mídias sociais são dois fatores apontados pelo artista e professor Joan Fontcuberta como razões fundamentais para a "inflação de imagens sem precedentes" vivida atualmente. Sobre a transformação na tecnologia móvel, Fontcuberta (2016) destaca o papel dos smartphones para a popularização dos registros fotográficos e defende que já não estamos mais frente a telefones que permitem tirar fotografias, mas sim frente a câmeras que permitem fazer chamadas telefônicas (FONTCUBERTA, 2016, p.16). Para ele, a aldeia global preconizada por Marshall McLuhan se transformou em uma "iconosfera", onde "habitamos a imagem e a imagem nos habita" (FONTCUBERTA., 2016, p. 9). Tal qual Fontcuberta, o pesquisador Norval Baitello Junior (2014), em sua obra A era da iconofagia, mostra a necessidade de repensar a proliferação desenfreada de imagens, já que esse aumento tem contribuído cada vez mais para a diminuição da "capacidade humana de enxergá-las" (BAITELLO, 2014, p. 129).

\subsubsection{DO TELÉGRAFO ÀS LIVES: A PLATAFORMIZAÇÃO DA SOCIEDADE}

As atividades diárias, sem dúvida, ficaram mais simples com a invenção dos smartphones, não apenas pelo aspecto da mobilidade da comunicação, mas também pela conexão instantânea que ele nos oferece com o mundo ao nosso redor. $O$ estreitamento de nossas relações com a tecnologia e com as telas faz parte de um processo de mudanças complexas e sistêmicas que foram analisadas pelo sociólogo Manuel Castells (1999). Nas últimas duas décadas do século XX, o pesquisador começou a identificar tendências da formação de uma nova estrutura social, que ele conceituou como sociedade em rede. 
[...] embora as redes sejam uma antiga forma de organização na experiência humana, as tecnologias digitais de formação de redes, características da Era da Informação, alimentaram as redes sociais e organizacionais [...]. Como as redes não param nas fronteiras do Estado-nação, a sociedade em rede se constituiu como um sistema global, prenunciando a nova forma de globalização característica do nosso tempo. (CASTELLS, 1999, p. II)

Essa nova forma de globalização, que deu seus primeiros passos com a invenção do telégrafo no final do século XIX, é vivida atualmente em sua forma mais potente. A simultaneidade nas comunicações e o encurtamento das distâncias, que hoje nos permitem assistir a shows dos nossos artistas favoritos em lives ${ }^{11}$ pelas mídias sociais, ao mesmo tempo que trouxeram mudanças, também potencializaram muitos hábitos que já eram comuns para as pessoas.

Em seu livro Culture of Connectivity a professora e pesquisadora holandesa José Van Dijck (2013), ao explicar como o hábito de utilizar as mídias sociais se tornou uma prática do cotidiano das pessoas, compara o tipo de interação realizada dentro de tais ambiências digitais com ações que antes eram comuns fora delas. Falar com os amigos, assistir a vídeos caseiros ou mostrar um álbum de fotos para a família são hábitos que costumavam ser privados, mas que, graças às mídias sociais, adquiriram uma publicização que nunca antes fora imaginada. $O$ que se resumia a um evento efêmero, que desaparecia no tempo e no espaço, hoje fica registrado nas plataformas, podendo ser resgatado e acessado novamente a qualquer momento. "As declarações anteriormente expressas de maneira informal agora são lançadas em domínio público, onde podem ter efeitos de longo alcance e duradouros" (VAN DIJCK, 2013, p. 7, tradução nossa ${ }^{12}$ ).

Para o pesquisador Lev Manovich (2016), que estuda as relações da humanidade com as transformações digitais, no século XX havia uma competição entre meios de comunicação, cada um usando suas próprias estratégias e comunicando a diferentes sentidos ou tipos de processos cognitivos, como impresso, rádio, cinema e televisão. Atualmente, ao contrário do que era visto antes, o autor acredita que a competição é entre aplicativos e plataformas de mídias sociais rivais que dividem o mesmo espaço dentro do smartphone (MANOVICH, 2016).

\footnotetext{
11 Lives é a maneira como ficou conhecida as transmissões ao vivo feitas pela Internet, principalmente nas mídias sociais.

12 "Utterances previously expressed offhandedly are now released into a public domain where they can have far-reaching and long-lasting effects".
} 
Essa nova disputa pelo mercado das mídias e da atenção humana está relacionada também à crescente plataformização das relações sociais (VAN DIJCK; POELL; DE WALL, 2020). Empresas como Facebook, Amazon e Google, também conhecidas como Big Techs $^{13}$ (MOROZOV, 2018), ganharam escala e um grande nível de penetração na sociedade, chegando ao ponto de interferir em diferentes setores, desde a economia até a política.

\begin{abstract}
A plataformização é definida como a penetração de infraestruturas, processos econômicos e estruturas governamentais das plataformas digitais em diferentes setores econômicos e esferas da vida. Ela também envolve a reorganização de práticas e imaginários culturais em torno dessas plataformas. (VAN DIJCK; POELL; DE WALL, 2020, p. 2)
\end{abstract}

No cerne da plataformização estão algumas estratégias que organizam as suas infraestruturas digitais. A partir da coleta sistemática de dados gerados pelos usuários e de um complexo processamento algorítmico ${ }^{14}$, as empresas monetizam essas informações por meio da circulação de dados entre anunciantes e outras empresas interessadas em sua compra (VAN DIJCK; POELL; DE WALL, 2020). Com isso, o contínuo aumento do tempo destinado ao uso das mídias sociais levanta questionamentos a respeito da nossa privacidade online.

Plataformas como o Facebook e o Twitter possuem mídias sociais que permitem que publicações sejam revisitadas, uma prática que arrisca o uso e a exposição de dados pessoais do passado dos usuários de maneiras descontextualizadas, o que poderia levar a constrangimentos ou à desinformação (BAYER et al, 2016; XU et al, 2016).

Convivemos com as telecomunicações sabendo, muitas vezes, apenas o básico de suas operações e funcionalidades. Enquanto isso, as plataformas digitais trabalham coletando as nossas informações, que são usadas como matéria-prima para as empresas de tecnologia fazerem dinheiro a partir da venda desses dados. Nick Couldry e Ulises Mejias (2019), pesquisadores das áreas de comunicação, economia e política, acreditam que vivemos em uma nova era do colonialismo. Em suas primeiras fases, a base do capitalismo era ligada à exploração de riquezas naturais e de mercadorias. Agora, ela é sustentada pela negociação de dados.

${ }^{13}$ Big Techs, segundo Morozov (2018), são grandes empresas ligadas a plataformas que comercializam dados de usuários e que estão situadas principalmente na América do Norte e na China.

${ }^{14} \mathrm{O}$ termo algoritmo é utilizado na área da computação para indicar um procedimento criado via códigos para cumprir uma tarefa específica. 
Se o colonialismo histórico anexou territórios, seus recursos e os corpos que trabalharam neles, a tomada de poder do colonialismo de dados é mais simples e profunda: a captura e o controle da própria vida humana através da apropriação dos dados que podem ser extraídos para obter lucro. Se isso estiver certo, assim como o colonialismo histórico criou o combustível para o eventual aumento do capitalismo industrial, o colonialismo de dados também está abrindo caminho para um capitalismo baseado na exploração de dados. A vida humana está literalmente sendo anexada ao capital. (COULDRY; MEJIAS, 2019, p. XI, grifos do autor, tradução nossa ${ }^{15}$ )

O discurso de legitimação do contínuo uso em larga escala dos dados proferido por governos e por empresas frequentemente argumentando seus benefícios é criticado na análise de Nick Couldry e Jun Yu (2018). Para eles, a naturalização do uso e da coleta de dados distancia o debate de questões éticas sobre o assunto, mascarando ações de vigilância e invasões de privacidade.

A amplitude do objeto traz complexidade para a questão. Os incontáveis usos de algoritmos no cotidiano das pessoas camuflam a própria presença das estratégias de coletas de big data. A falta de transparência das empresas que prestam serviços e coletam dados dos consumidores gera uma desorientação por parte dos usuários, que não sabem sequer o que é registrado de sua vida. Assim, não sabendo que os dados existem ou que são coletados, perde-se o controle sobre a sua distribuição.

Para minimizar a sensação de desorientação, dentro da cultura de ordenamento de big data nascem as hashtags, que se popularizaram ao serem adotadas de maneira pioneira pelo Twitter, plataforma de rede social de micropostagens, em 2007. Desde então, outras plataformas também adotaram essa forma de agrupamento de postagens, usada também como termômetro dos assuntos do momento nas redes sociais por meio de listas de Trending Topics (expressão que pode ser traduzida como "tópicos em alta"), com as hashtags mais utilizadas pelas pessoas em tempo real (MADRIGAL, 2013, online).

Em 2006, na primeira edição de seu livro "Cultura da Convergência", que popularizou a expressão "cultura da participação", Jenkins concluiu que as pessoas teriam mais poder de fato quando reconhecessem que a participação nas mídias poderia servir não apenas em seu papel como consumidores junto a marcas, mas

15 "If historical colonialism annexed territories, their resources, and the bodies that worked on them, data colonialism's power grab is both simpler and deeper: the capture and control of human life itself through appropriating the data that can be extracted from it for profit. If that is right, then just as historical colonialism created the fuel for industrial capitalism's eventual rise, so too is data colonialism paving the way for a capitalism based on the exploitation of data. Human life is quite literally being annexed to capital". 
também como cidadãos (JENKINS, 2009, p. 343). Tal postura começou a tomar forma na sociedade a partir de dezembro de 2010, com a onda de protestos em países do Oriente Médio que ficaria conhecida como Primavera Árabe. Ao analisar o movimento e o papel das mídias sociais nesse contexto, Castells (2013, p. 14) avalia que o Twitter "desempenhou papel de destaque na discussão dos eventos e na coordenação da ação" através do uso de hashtags.

A contínua transformação da tecnologia da comunicação (TI) na era digital amplia o alcance dos meios de comunicação para todos os domínios da vida social, numa rede que é simultaneamente global e local, genérica e personalizada, num padrão em constante mudança. $O$ processo de construção de significado caracteriza-se por um grande volume de diversidade. Existe, contudo, uma característica comum a todos os processos de construção simbólica: eles dependem amplamente das mensagens e estruturas criadas, formatadas e difundidas nas redes de comunicação multimídia (CASTELLS, 2013, p. 14).

Por conta dessa característica que a coloca como um mecanismo de agrupamento de opiniões coletivas, a hashtag também se tornou "a cara de movimentos de impacto real" (TERRA, 2019, online). Com o intenso uso de hashtags entre os movimentos sociais que saem do ambiente virtual para as ruas, Terra (2019) descreve o seu uso como um novo índice da memória coletiva social.

As histórias narradas por meio de hashtags também ajudam a humanizar situações que poderiam soar distantes caso fossem representadas apenas por percentuais em títulos de reportagens. Nesse contexto, a "\#" é bastante valiosa para grupos que têm menos voz na sociedade (TERRA, 2019, online).

Ao lado das hashtags, outra estrutura que auxilia a organização e o processo de comunicação nas mídias sociais é a ferramenta de geolocalização. "A geolocalização impõe a dimensão do espaço para o número" (RAMOS, 2016, p. 155). Pavlik (2014) acrescenta que o uso desse tipo de metadado ${ }^{16}$ é uma característica que vem ganhando espaço entre os conteúdos midiáticos publicados online, com grande potencial de expansão, favorecendo os valores imersivos e interativos.

Na próxima década, conteúdos ubíquos geolocalizados em mídias móveis e dispositivos adaptados ao corpo provavelmente conduzirão a uma nova forma de jornalismo sem as barreiras impostas pelas tradicionais plataformas de

16 Dados fora de contexto e sem identificação costumam trazer confusões para o entendimento das informações, seja por parte do usuário, seja por parte da execução de comandos das máquinas envolvidas no processo. Para dar sentido a um dado, ele precisa ser organizado semanticamente a partir de metadados. De maneira simplificada, os metadados são dados sobre dados. O tagging (ou etiquetamento, em português) permite mais agilidade na localização e na leitura de informações a partir de palavras-chave anexadas ao dado original. 
apresentação de notícias. Em vez disso, os cidadãos usarão seus telemóveis ou os wearables para acessar ou contribuir com o conteúdo noticioso geolocalizado em qualquer lugar de cada comunidade. Os cidadãos irão se envolver em narrativas imersivas e interativas como se estivessem em uma máquina do tempo virtual enquanto percorrem suas comunidades. Estas narrativas imersivas fornecerão um contexto geográfico ainda mais rico do que aquele possível na mídia tradicional (PAVLIK, 2014, p. 176)

Assim, chegamos ao século XXI precisando lidar com o excesso informacional e com os riscos à privacidade dos usuários na Internet, mas com a possibilidade de combinar cada vez mais elementos de contexto comunicacional às imagens publicadas na Internet. Uma mistura desses três fenômenos serviu de berço para o nascimento das mídias sociais que oferecem formatos efêmeras, assunto do nosso próximo tópico.

\subsubsection{CONTAÇÃO DE STORIES: AS NARRATIVAS COM DATA DE VALIDADE}

O hábito de contar histórias é praticado pela humanidade para expressar suas ideias e sentimentos desde os mais remotos tempos. Com o desenvolvimento tecnológico, novas ferramentas se agregam a essa condição intrínseca do ser humano para contribuir para a produção e a veiculação de suas narrativas. Nos últimos anos, a partir do surgimento das mídias sociais com publicações efêmeras, como o Snapchat e o Instagram Stories, o fazer narrativo ganhou novas possibilidades de construção e de acesso dentro dos Stories, um recurso midiático que converge diversos formatos de mídia, voltado para o ambiente digital dos dispositivos móveis.

a) O nascimento dos Stories no Snapchat:

Os Stories nascem em 2013, dentro do Snapchat, uma plataforma de troca de mensagens com base em mensagens e imagens que se apagam após um tempo determinado pelo criador do conteúdo. O Snapchat foi criado em 2011 por Evan Spiegel e Bobby Murphy. Em suas primeiras versões, o aplicativo permitia apenas a comunicação direta entre amigos, com o envio de mensagens de texto e fotos (conhecidos como snaps). Cada snap desaparecia depois de um número específico de segundos após a visualização, definido pelo remetente. Em outubro de 2013, foi adicionada ao aplicativo a função Snapchat Stories, que compilava snaps em uma 
sequência narrativa que poderia ser vista ilimitadas vezes, durante um período de 24 horas (ETHERINGTON, 2013, online).

Com o lançamento dos Stories, o Snapchat inaugurou um novo tipo exibição de conteúdo via mídias sócias em smartphones: fotos e vídeos que ocupam toda a tela na posição vertical do dispositivo (SOUZA E SILVA; VELLEI, 2020), divididos em fragmentos com duração de 1 a 10 segundos cada, mostrados linearmente em ordem cronológica e que são apagados após a duração exata de um dia. Seu cocriador, Evan Spiegel, durante uma conferência de tecnologia em 2014, contou que o diferencial do Snapchat é o foco "na experiência da conversação - não na transferência de informação"17.

Com o desenvolvimento da tecnologia e a transposição de barreiras que impediam que as comunicações fossem instantâneas e móveis, a cultura criada pelo Snapchat defende que o conteúdo compartilhado de forma permanente não seja uma prioridade. Ao contrário de outras plataformas online de troca de mensagens, que se baseiam em acervos de dados pessoais dos usuários, a experiência do Snapchat tem como parâmetro uma conversa presencial: espontânea e efêmera (VELLEI, 2019).

\begin{abstract}
A função da fotografia pessoal como um ato de memória está cada vez mais dando lugar a seus usos formativos, comunicativos e experienciais. Sistemas em rede definem novos contextos de apresentação de imagens pessoais, pois o compartilhamento de fotos torna-se o modo padrão dessa prática cultural. De muitas maneiras, ferramentas digitais e sistemas de conectividade expandem o controle sobre a exposição da imagem de um indivíduo, concedendo a ele mais poder para se apresentar e se moldar em público. (VAN DIJCK, 2008, p. 71, tradução nossa ${ }^{18}$ )
\end{abstract}

Assim, tendo como centralidade a câmera do celular, o Snapchat surge seguindo a tendência de transformar a imagem fotográfica em uma experiência comunicacional para além da experiência documental que deu origem à técnica.

A efemeridade do Snapchat começou a desempenhar um papel fundamental na formação de relações íntimas entre os seus usuários, pois a exclusão padrão do

\footnotetext{
17 "Snapchat focuses on the experience of conversation - not the transfer of information". Palestra feita no AXS Partner Summit, em janeiro de 2014. Veja a integra do discurso: https://www.snap.com/ptBR/news/post/2014-axs-partner-summit-keynote

18 "The function of personal photography as an act of memory, as we have seen, is increasingly giving way to its formative, communicative and experiential uses. [...] Networked systems define new presentational contexts of personal pictures, as sharing pictures becomes the default mode of this cultural practice. In many ways, digital tools and connective systems expand control over an individual's image exposure, granting her more power to present and shape herself in public."
} 
conteúdo passou a deixar as pessoas mais à vontade para postar conversas "rotineiras e mundanas" e a interagir de maneira mais lúdica com os seus contatos (Xu et al, 2016).

O Snapchat virou um ambiente usado para compartilhar experiências íntimas para uma rede de contatos "confiáveis", tendo adolescentes e jovens adultos como seu público principal. De acordo com Bayer et al. (2016), esse diferencial trazido pelas mídias sociais efêmeras fez delas um componente proeminente do ecossistema digital.

b) A chegada dos Stories ao Instagram

O Instagram foi lançado em 2010 como um aplicativo gratuito para o sistema iOS, criado por Kevin Systrom e Mike Krieger, com o objetivo de ser um local para compartilhamento de fotos entre amigos. Depois de lançar a versão para Android e atingir mais de trinta milhões de downloads, o aplicativo foi adquirido pelo Grupo Facebook em abril de 2012. Desde então, a plataforma continuou a crescer tanto na base de usuários como em suas funcionalidades. Foram adicionados novos filtros, geolocalização, tagueamento de outras contas nas fotos, a possibilidade de adicionar vídeos de até um minuto diretamente no feed, mensagens privadas diretas entre usuários e novas opções de tamanho de imagens além da proporção quadrada, formato que marcou os seus primeiros anos de existência.

Vendo o sucesso atingido pelo concorrente Snapchat com o formato Stories, a exclusividade da ferramenta foi desbancada pelo Instagram, que introduziu a função em sua estrutura em 2016. Antes do seu lançamento, a plataforma digital de compartilhamento de imagens contava com uma base de aproximadamente 500 milhões de usuários. Desde então, essa nova estrutura para contar e assistir histórias contribuiu ainda mais a popularização da plataforma. Em 2020, ano em que o Instagram completou uma década de existência, a empresa já possuía mais de um bilhão de utilizadores ativos todos os meses, segundo dados divulgados pela empresa $^{19}$. Hoje usada por mais de 500 milhões de pessoas por dia, a criação de histórias que se apagam automaticamente no Instagram é um fenômeno

${ }^{19}$ A empresa não divulga o número exato de usuários, apenas que a quantia ultrapassa 1 bilhão de pessoas. Para saber mais: https://about.instagram.com/about-us 
comunicacional que, assim como em seu concorrente, também é caracterizado pela possibilidade de alocar fotos, vídeos e textos que ocupam a tela inteira do celular e duram, no máximo, 24 horas, sendo apagados automaticamente após esse período.

O cofundador do Instagram, Kevin Systrom, ao ser questionado sobre a semelhança dos Stories do Instagram com os Stories do Snapchat, afirmou em uma entrevista coletiva concedida à imprensa que "outras companhias merecem todo o crédito" pela popularização dos Stories. Sem mencionar o concorrente, ele disse que a sequência narrativa de fotos e vídeos que desaparecem após 24 horas é um formato, semelhante ao modelo de feed em cascata popularizado por empresas como Facebook e Twitter e eventualmente adotados por inúmeros outros (ISAAC, 2016, online, tradução nossa ${ }^{20}$ ).

Essa "livre adaptação" feita pelo Instagram da estrutura advinda do Snapchat é uma das consequências do fenômeno da plataformização (VAN DIJCK; POELL; DE WALL, 2020). Em suas características essenciais, "as arquiteturas das plataformas são modulares em seu design, de modo que a tecnologia pode ser aberta seletivamente a complementadores para criar e integrar seus serviços a serem usados pelos usuários finais" (VAN DIJCK; POELL; DE WALL, 2020, p. 3-4). Outras plataformas digitais, como Facebook, WhatsApp, Messenger, Twitter e LinkedIn também adotaram o formato em suas estruturas (MONTEIRO, 2020).

Em 2017, os Stories do Instagram passaram a oferecer formas de organizar e armazenar as histórias visuais, o que tornou essa mídia social efêmera (BAYER et al, 2016) já não tão mais efêmera. Seus desenvolvedores criaram a possibilidade de exibição de conteúdo de forma mais duradoura para os usuários. Inicialmente, todas as histórias expiravam após 24 horas. No entanto, em dezembro de 2017, foi introduzido o recurso Destaque e Arquivo. Com isso, as pessoas passaram a poder agrupar stories publicados em dias diferentes, criando uma sequência que fica destacada em seu perfil, sem limite de tempo para sua expiração. A atualização também permitiu que os stories ficassem salvos automaticamente na conta da pessoa, criando um arquivo pessoal que pode ser revisitado em outros momentos para republicação no próprio Stories ou agrupado em um Destaque no perfil.

20 "Instead, he said the narrative string of photos and video that disappear after 24 hours is a format, akin to the cascading feed-based model popularized by companies like Facebook and Twitter and eventually adopted by countless others." 
c) Características do interfaceamento digital dos Stories no Instagram

Todas essas movimentações em torno da criação de formatos visualmente atraentes para as telas portáteis mostram uma tentativa de adequar os processos criativos levando-se em conta o protagonismo dos smartphones na sociedade. Os dispositivos móveis, produtos da cultura da convergência (JENKINS, 2009), influenciam a busca por novas maneiras de comunicar, uma vez que a sociedade tem dedicado a eles uma parcela cada vez maior de seu tempo ${ }^{21}$.

Percebemos, com isso, uma circularidade maior entre o fazer narrativo e as transformações tecnológicas dos meios de comunicação. Assim, as relações interpessoais passaram a ser cada vez mais mediadas por interfaces digitais de comunicação, uma condição profundamente explorada pelo Instagram.

Essa é uma característica presente na plataforma antes mesmo da introdução dos Stories, principalmente pela facilitação da adição de filtros às imagens. Souza e Silva (2015b, p. 339) explica que as suas ações pré-programadas permitem uma decodificação mais fluída para a produção de imagens e para a comunicação entre os usuários.

\begin{abstract}
Ao simplificar os processos de experimentação estética em suas imagens, o Instagram, por meio dessas ações pré-programadas, acessíveis a um simples toque, articula, num certo sentido, uma estratégia para garantir um mesmo repertório de intervenção e manipulação, a fim de permitir uma decodificação mais fluída entre seus usuários. (SOUZA E SILVA, 2015b, p. 339).
\end{abstract}

Tendo como base o conceito de interfaceamento digital, proposto por Souza e Silva (2015), entendemos que a interface - no sentido de instância mediadora entre duas partes - é capaz de congregar até três níveis de interfaceamentos simultâneos: o da construção (a materialidade da tela do smartphone), o da comunicação (os canais no ambiente da mídia social) e o da significação (o mundo da imagem). Uma vez que o universo digital assume a tela como primeira interface, de fato, estamos nos referindo à possibilidade da conjunção desses três modos de aproximação para a produção de stories.

\footnotetext{
${ }^{21}$ Entendemos o processo de convergência como um fenômeno maior, para além dos avanços no nível tecnológico dos meios de comunicação. Jenkins (2009) reforça que a sociedade vive uma profunda uma transformação cultural, com a participação muito mais ativa das pessoas. Como processo mental, a convergência acontece nos próprios indivíduos e em suas interações sociais. Dessa forma, "[...] a convergência representa uma mudança no modo como encaramos nossas relações com as mídias" (JENKINS, 2009, p. 51).
} 
Para Ramirez (2019), os Stories do Instagram tornaram acessíveis conceitos e usos do design para uma ampla população por meio de sua interface préprogramada. Na figura 1.2, exemplificamos, em um mosaico de capturas de tela de um smartphone, os principais elementos gráficos que constituíam um caminho possível para o usuário publicar um story, em novembro de 2020:

1) Ao entrar no Instagram, o usuário encontra na página de início os stories publicados. Ao clicar no sinal de (+) no primeiro círculo, a câmera se abre para a criação de um story.

2) É possível inserir filtros que modificam a imagem. A comunidade de usuários do Instagram pode criar e compartilhar seus próprios filtros para outras pessoas.

3) Essas são as ferramentas de captura de imagem. Em Criar é possível adicionar textos, sem necessariamente o uso de uma fotografia; em Boomerang, o vídeo gravado repete-se em looping. Em Captura múltipla, o usuário consegue tirar diversas fotos e publicar mais de um story ao mesmo tempo. Layout permite a criação de conjuntos de duas ou mais imagens utilizando modelos próprios de composição; em Superzoom, o vídeo captura e amplia uma parte previamente escolhida pelo usuário, simulando o efeito de aproximação (zoom) e, finalmente, Mãos livres permite a gravação de sequências de vídeos sem precisar tocar na tela.

4) Depois de criar a imagem, o usuário é levado para uma etapa na qual ele pode personalizar ainda mais a fotografia, vídeo, ou texto produzido. São oferecidos novos filtros, etiquetas, desenho à mão ou a inserção de novos blocos de textos.

5) Existem três opções de compartilhamento dos stories. No primeiro círculo, o conteúdo é publicado para todos os seguidores. No segundo círculo, apenas os amigos próximos (perfis previamente selecionados) recebem a postagem. E, em enviar para, a imagem é direcionada privadamente pelo Direct (mensagem direta). 
Figura 1.2 - Opções pré-programadas de design dentro dos Stories
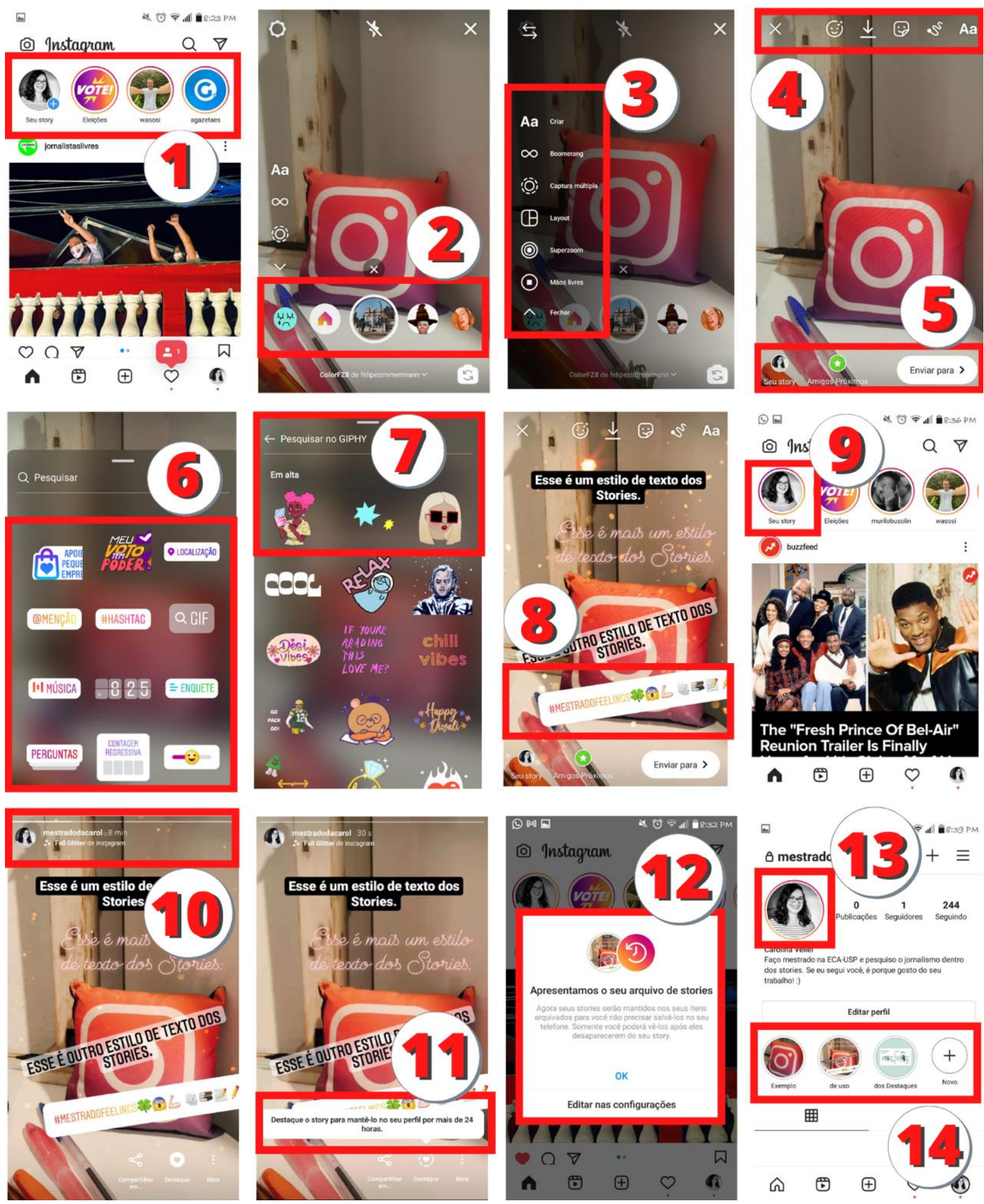

Fonte: a autora (2020), a partir de capturas de tela da interface do Instagram. 
6) Opções de personalização de etiquetas. As etiquetas podem variar conforme o perfil do usuário: se é uma conta comercial ou não, se uma data festiva local está próxima ou segundo a sua geolocalização. Destacam-se as etiquetas de metadados que permitem a interação de outros usuários no conteúdo publicado, conforme o tipo: de localização, menção a outros perfis, hashtags, música, perguntas, entre outras.

7) Os Stories também oferecem a opção de personalização por meio de gifs e emojis ${ }^{22}$, que podem ser localizados com a ferramenta de busca.

8) Depois de personalizado, o story pode ser compartilhado. No exemplo, utilizamos uma etiqueta de hashtag acompanhada com emojis, e fizemos uma demonstração de alguns estilos de tipografia disponíveis.

9) Depois de publicado nos Stories, a foto de perfil do usuário apresenta um anel colorido em sua volta, o que indica a presença de conteúdo novo que ainda não foi visualizado pelo próprio usuário. Ao clicar no círculo o anel fica com a cor branca.

10) Dentro do story já publicado, a linha acima do nome do perfil indica a quantidade de stories disponíveis para visualização. Quanto mais stories, mais divisões existem na linha. O Instagram permite até 100 stories simultâneos, que passam a ser indicados por uma linha pontilhada.

11) A plataforma indica a possibilidade de alocar a imagem publicada em um destaque dentro do perfil do usuário, fazendo com que o story possa ser visualizado mesmo após 24 horas.

12) Caso o usuário não deseje destacar a imagem durante o período de 24 horas, ele pode fazê-lo depois a qualquer momento, bastando acessar seus arquivos privados dentro da plataforma.

13) Ao entrar no perfil de um usuário, a foto também recebe um anel colorido caso possua atualizações com novos stories.

22 Gifs são e emojis são elementos imagéticos utilizados na comunicação. Os emojis foram criados por Shigetaka Kurita, no Japão, na década de 90 . O termo surgiu a partir da junção de duas expressões japonesas: "e" (imagem) e "moji" (personagem). São considerados pictogramas, ou seja, imagens que transmitem a ideia de uma palavra ou frase completa. Já os gifs (Graphics Interchange Format ou formato de intercâmbio de gráficos) foram criados em 1987, pela empresa CompuServe com o objetivo de armazenar várias imagens em um formato compacto e exibi-las com qualidade (QUEIROZ, 2019). 
14) Os círculos abaixo da área de biografia são os Destaques. A capa e o título dos círculos podem ser personalizados e cada grupo pode reunir até 100 stories.

d) Um desejo inato de ouvir e de contar histórias

Para entender a popularidade dos Stories, é preciso compreender a função das narrativas na vida das pessoas. Desde a pré-história, com a produção de pinturas rupestres, a humanidade se empenha em registrar suas vivências e mostrá-las ao mundo, fabricando ferramentas e sistemas de sentido que representem suas ideias. Dessa maneira, o poder de se expressar apresenta-se como uma condição básica do desenvolvimento humano (ERSTAD e WERTSCH, 2008).

Entendemos que "narrar é uma habilidade inerente ao ser humano" (MUNGIOLI, 2002, p. 49), sendo a narração um gênero onipresente no ambiente social e cultural das pessoas. É por meio de histórias que os vínculos entre os agentes da sociedade são estabelecidos. "O gênero narrativo é usado não só como uma forma de demonstrar e interpretar suas relações com o mundo e com as pessoas que o cercam como também de ser compreendido e interpretado" (MUNGIOLI, 2002, p. 49).

Jerome Bruner (2002), psicólogo estadunidense e um dos pioneiros nos estudos de psicologia cognitiva moderna, analisou a narrativa sob a perspectiva do desenvolvimento humano. Para ele, a linguagem é a ferramenta mais poderosa para a organização de experiências e para a construção da forma como as pessoas enxergam a realidade. Fortemente influenciado pelos estudos culturais e sociais do psicólogo bielo-russo Lev Vygotsky, Bruner descreve a linguagem como uma "maneira de se selecionar os pensamentos sobre as coisas. O pensamento é um modo de organizar a percepção e a ação" (BRUNER, 2002, p. 77).

Em seu livro "A cultura da educação", o pesquisador aponta a impossibilidade de distinguir o que é um modo de pensamento e o que é um "texto" ou discurso narrativo. De acordo com o estudioso norte-americano, "cada um deles dá forma um ao outro, do mesmo modo que o pensamento se torna inextrincável da linguagem que o expressa e que acaba moldando-o" (BRUNER, 2001, p. 128). A narrativa, para ele, tem um papel central no pensamento humano e funciona como um veículo para o significado. É a forma como as pessoas criam suas próprias versões de mundo. 
Tomando como base a perspectiva sócio-histórica de Vygotsky e Bruner sobre o desenvolvimento cognitivo e sua relação com as narrativas, pode-se afirmar que o comportamento humano e, portanto, suas manifestações em plataformas digitais como o Instagram e o uso de mídias como os Stories, devem ser analisados levandose em conta aspectos sociais, históricos e culturais.

Mungioli (2002, p. 53) aponta que, "para Vygotsky, o cognitivo e o afetivo são duas dimensões humanas inseparáveis que são construídas pelo seu interrelacionamento e influências mútuas". Desse modo, a predileção inata pelo gênero narrativo contribui para o sucesso da adesão aos Stories como espaços para criação de histórias com alto teor de interação e ligações emocionais entre as pessoas. Esse vínculo é amplificado devido à característica do apagamento automático de suas publicações. A sua essência efêmera favorece a interação íntima e autêntica entre as pessoas, que se sentem mais livres para postar conteúdos espontâneos e pessoais (LEMOS; SAMPAIO, 2018).

e) O uso jornalístico dos Stories:

O fazer narrativo está no cerne do jornalismo, especialmente se considerarmos que as narrativas jornalísticas ${ }^{23}$ são estórias ${ }^{24}$ sobre o mundo real contadas por jornalistas (BERTOCCHI, 2006, p. 126), o que faz do jornalismo uma profissão essencialmente especializada em contar histórias.

\begin{abstract}
A convicção de que o "real" pode ser transmitido "sem linguagem" contribui para o afastamento do termo "narrativa" ao da "notícia", como se fossem duas coisas distintas, e que se anulam devido à ficcionalidade da narrativa e à realidade da notícia.[...] Reiteramos que não queremos dizer com isto que as narrativas jornalísticas primem pelo ficcional, sejam irreais ou mentirosas (embora infelizmente possam sê-lo), mas queremos assumir que "narrar um acontecimento" não é o mesmo que o próprio "acontecimento". Significa dizer, deste modo, que as narrativas jornalísticas, as notícias e as reportagens, podem ser entendidas como "estórias". (BERTOCCHI, 2006, p. 107-109).
\end{abstract}

Os aspectos que fizeram dos Stories um formato de mídia com grande potencial narrativo começaram a ser explorados por empresas dos setores de entretenimento e notícias a partir de 2016, logo após seu lançamento no Instagram.

\footnotetext{
${ }^{23}$ Seguindo o entendimento de Bertocchi (2006), no nosso trabalho as narrativas jornalísticas dizem respeito principalmente ao que conhecemos tradicionalmente como notícia e reportagem.

${ }^{24}$ Entendemos a palavra "histórias" como sinônimo de estórias.
} 
Em abril de 2018, a Folha publicou um texto chamado "Manual de Storiestelling", escrito pelo jornalista Mateus Camillo (2018), editor e produtor de Stories da empresa.

Dividido em dez tópicos, o manual orienta como extrair o melhor do formato:

Você está contando uma história, portanto, lembre-se do básico em contação de histórias: começo, meio e fim. Ter em mente o conceito de jornada do herói, de Joseph Campbell, pode Ihe ser útil na hora de desenvolver a narrativa. [...] Começar com "Era uma vez", por exemplo, funciona bem. Entregue a história aos poucos, forçando a curiosidade para que o seguidor continue no próximo Stories. (CAMILLO, 2018, online, grifos do autor)

Entretanto, pensando na cadeia produtiva de jornalismo como um todo, outras questões além dos aspectos narrativos entram em jogo com a introdução de uma nova forma de produzir conteúdo. Ao comentar sobre as intensas mudanças sofridas no cenário das mídias nos últimos anos, a pesquisadora Daniela Ramos (2016), especialista em jornalismo de dados, afirma que a criação do Snapchat atualizou os desafios para os produtores de notícias:

Para dar um nó nessa conectividade toda, ainda estamos tentando entender o Snapchat, aplicativo-rede social e uma espécie de esfinge contemporânea para alguns da geração anterior aos anos 1990. No "Snap", a home não é um feed de informações, como até então estava convencionado, mas o acesso à câmera do celular. Sinais dos tempos. (RAMOS, 2016, p. 23)

Aprofundaremos essas questões durante a nossa análise da produção nos Stories do Estadão e da Folha no segundo e no terceiro capítulos. Mas, antes, traremos no próximo tópico um panorama do jornalismo contemporâneo, com as suas principais transformações no cenário global de mídias. Falaremos sobre a crise gerada pela difusão de desinformações e conheceremos algumas das novas formas de produzir e de consumir notícias. 


\subsection{A PRÁTICA JORNALÍSTICA ENTRE CRISES E TRANSFORMAÇÕES}

No dia 7 de novembro de 2020, um repórter do canal de TV News 12, nos Estados Unidos, foi surpreendido durante uma entrada ao vivo enquanto anunciava a vitória do democrata Joe Biden nas eleições presidenciais. O repórter, ao perceber que uma pessoa havia parado atrás dele - portanto, dentro do enquadramento da câmera -, virou-se e perguntou: "Como você está, amigo?". Então, o homem responsável pela interrupção, que trajava camiseta e máscara da campanha de Donald Trump, adversário derrotado de Biden, começa a questionar: "Isso é uma notícia real ou uma notícia falsa?". Nesse momento, o jornalista, ainda de costas para a câmera e de frente para o homem, responde, quase sem hesitar: "Sai fora!". Com um sorriso no rosto e com uma fisionomia visível de orgulho estampada em sua expressão, o repórter retoma a transmissão ao vivo, enquanto o eleitor de Trump profere um sonoro: "O quê?", aparentando estar um pouco desnorteado.

A cena viralizou ${ }^{25}$ após uma usuária da plataforma $T_{i k T o k^{26}}$ ter postado um vídeo que ela mesma gravou com a câmera do celular enquanto assistia à transmissão da cobertura das eleições pela tela de sua televisão. O momento exato do ocorrido foi reproduzido contendo o diálogo dos envolvidos em áudio e em legendas, transcritas pela própria usuária, além de um emoji de "carinha feliz" com corações. Ao final, ouviase uma comemoração em alto e bom som de sua parte (figura 1.3).

Em menos de seis horas, o vídeo atingiu 3,2 milhões de visualizações, mais de 940 mil curtidas e quase 100 mil compartilhamentos no TikTok. Com isso, vídeo também foi postado no Instagram e no Twitter, onde também viralizou.

\footnotetext{
${ }^{25}$ Adotamos o termo viralizar para nos referir aos conteúdos que são compartilhados em um curto espaço de tempo e de forma massiva no nosso trabalho porque entendemos que essa é a expressão utilizada frequentemente pelos veículos de comunicação para noticiar essas ocorrências, o que tornou a expressão mais conhecida. No entanto, temos como norte os estudos dos pesquisadores Jenkins, Ford e Green (2014), que denominam esse tipo de conteúdo que se espalha com facilidade como mídia propagável. Diferentemente de um vírus, os autores defendem que o fenômeno não surge "do nada" como mágica e não se comporta como uma doença contagiante, a qual as pessoas não têm controle sobre as suas causas e seus resultados. Apesar de ser difícil rastrear as motivações por trás das mídias ditas "virais" e de também não existir uma receita pronta para que uma postagem em tenha um alto apelo para compartilhamento, estudos culturais e sociais no campo da comunicação podem nos levar a entender o que leva uma pessoa a selecionar algumas publicações e outras não para repassar a seus contatos.

${ }^{26}$ Tiktok é uma plataforma digital de mídia social chinesa conhecida por incentivar a propagação de conteúdo dos seus usuários em outras mídias sociais de plataformas concorrentes, por isso, ao compartilhar, a empresa automaticamente coloca uma marca d'água com o logo do TikTok e o endereço do perfil criador das imagens.
} 
Tivemos acesso a esse vídeo no próprio dia 7, enquanto acompanhávamos as comemorações - e, também as reclamações, - dos norte-americanos sobre o resultado das eleições nas mídias sociais. Nas imagens, era possível ver o nome do repórter, Alex Zdan, e o endereço de sua conta no Twitter, uma prática de muitos canais televisivos para estimular a interação online com a audiência, a chamada social TV (BULKELEY, 2010).

Figura 1.3 - Destaques do momento em que o repórter Alex Zdan reage à atitude do eleitor de Trump
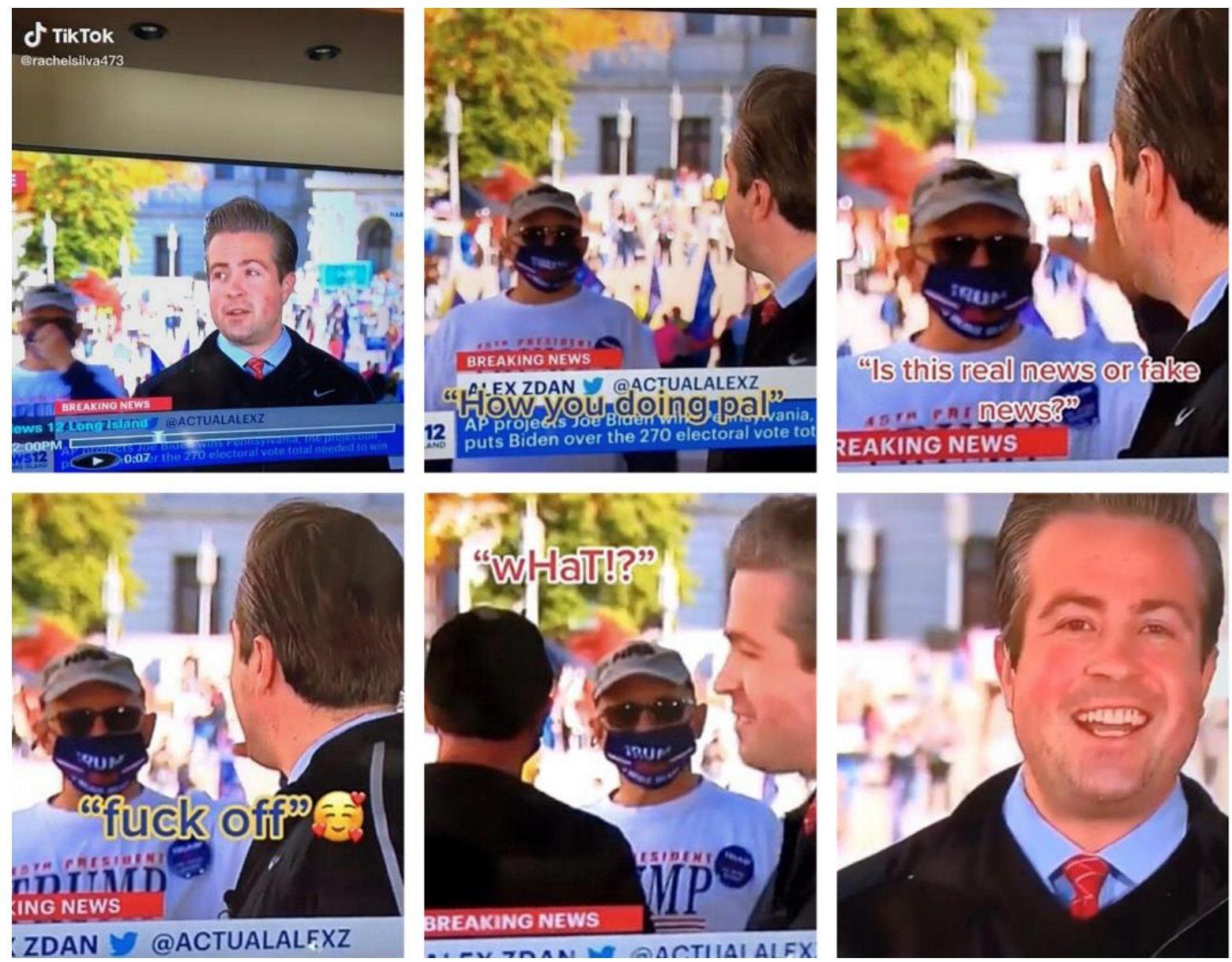

Fonte: a autora (2020), adaptado de @rachelsilva473 no TikTok

Curiosos para saber a repercussão do caso na vida do jornalista, decidimos acessar a página do repórter no Twitter. Vimos uma publicação feita algumas horas após a viralização do vídeo, na qual se defendia e tentava esclarecer o incidente, alegando que teria dito "buzz off' (maneira informal de pedir que alguém se retire) ao 
invés de "fuck off" (forma ofensiva de pedir que alguém se retire), como a usuária havia transcrito na imagem ${ }^{27}$.

Na postagem (figura 1.4), além do esclarecimento, o profissional também demonstrou surpresa pelo alcance do acontecimento e agradeceu o carinho das pessoas nas mídias sociais, mas pediu respeito aos membros da imprensa que "estão fazendo seus trabalhos e contando suas histórias" (ZDAN, 2020, online, tradução nossa).

Figura 1.4 - Postagem do repórter Alex Zdan no Twitter ${ }^{28}$

Alex Zdan @ActualAlexZ ·4min
So THAT'S what it's like to go viral...
Look I appreciate the social media love, but I told the guy behind me to
BUZZ off when he interrupted me live on @news12.
But please respect members of the press who are doing their jobs, and
telling your stories.
@RexChapman @News12NJ
๑1.050

Foto: captura de tela da autora (2020)/ reprodução via Twitter

Imediatamente, Zdan começou a receber respostas de usuários em sua defesa, apoiando a atitude do jornalista, independentemente de a expressão ter sido "buzz off' ou "fuck off". O repórter foi considerado um "herói americano" e diversas pessoas o elogiaram por demonstrar felicidade após ter se defendido do homem que o provocou com a fala sobre fake news, uma acusação comumente utilizada pelos seguidores de Trump para atacar o trabalho da imprensa (figura 1.5).

27 Nos Estados Unidos, é proibido falar nas transmissões de TV e rádio conteúdo "profano ou indecente", como um xingamento, das $06 \mathrm{~h}$ às $22 \mathrm{~h}$, sob o risco de aplicação de multa ao canal. Ver mais: https://www.fcc.gov/consumers/guides/obscene-indecent-and-profane-broadcasts

28 Tradução nossa: "Então é assim que é quando viralizamos... Olha eu aprecio o amor das mídias socias, mas eu falei para o cara atrás de mim para "sair fora" quando ele me interrompeu ao vivo no @news12. Mas por favor respeitem os membros da imprensa que estão fazendo o seu trabalho e contando suas histórias" 
Figura 1.5 - Publicações no Twitter em defesa do jornalista Alex Zdan29

Hunter deBlanc $\bullet$
@hunterdeblanc
i want that energy to be the standard from all journalists
moving forward

Foto: captura de tela da autora (2020)/ reprodução via Twitter

A história não começou no Instagram, mas também foi parar na plataforma, entre os usuários dos Stories e do feed permanente. Apesar do momento de euforia graças à vitória de Joe Biden, percebemos que a reação espontânea de Zdan levantou um extenso debate nos comentários de sua publicação no Twitter - onde acompanhamos o desenrolar do caso - sobre a necessidade de rever a postura da imprensa e a expectativa da não demonstração de emoções por parte dos jornalistas como uma forma de preservar a credibilidade e a objetividade da informação.

Tal comportamento também repercutiu nas outras redes da mesma forma, inclusive no Instagram, o que nos instigou a tentar entender os prováveis motivos para o sucesso do vídeo.

29 Tradução nossa, seguindo a sequência da esquerda para a direita: 'Eu quero que essa seja a energia padrão de todos os jornalistas daqui pra frente"; "Não importa a palavra, a emoção estava correta"; "Mantenha o seu emprego, rei, mas nós sabemos o que você disse e nós te amamos por isso"; "Eu nem mesmo uso o Twitter, mas vi esse vídeo icônico em uma página de memes no Instagram (IG), o que me trouxe aqui, porque você deveria saber que é um herói americano de verdade"; "Nós precisamos de você contanto as histórias - nos dando a informação que precisamos ouvir!"; "Eu pensei que você tinha dito 'se manda', mas não importa. Foi muito revigorante ver alguém da imprensa capaz de se defender. Eu admiro você"; "Sabemos o que você disse, mas nós sabemos o que estava pensando. Mesmo para dizer "sai daqui" é preciso muita coragem para um repórter"; "Gostamos de um confiante, assertivo repórter". 
Ao estudarmos as mídias propagáveis, conseguimos listar algumas das motivações que podem ter desencadeado a rápida circulação das imagens, segundo critérios apontados por Jenkins, Ford e Green (2014). Entre elas, a controvérsia gerada pelo seu conteúdo, a identificação com o comportamento representado e a possibilidade de geração de conversa a partir de um assunto já em andamento nas redes, como foi o caso das eleições norte-americanas. A surpresa ao ver um jornalista falando de maneira direta como Alex Zdan fez, pode ter funcionado como gatilho para que a usuária @rachelslva473 editasse e compartilhasse o vídeo no TikTok ${ }^{30}$.

$\mathrm{O}$ apoio à postura do jornalista veio acompanhado do desejo de que outros membros da imprensa também passassem a agir de forma mais franca e autêntica. Beckett e Deuze (2016), pesquisadores da área de comunicação, afirmam que as emoções inspiram conexão e impulsionam o relacionamento íntimo das pessoas com a tecnologia, além de estimular "o envolvimento com notícias e informações e inspirar os profissionais a seguirem carreiras em um setor que oferece tudo, menos recompensas confiáveis por um trabalho bem executado" (BECKETT; DEUZE, 2016, p. 2, tradução nossa ${ }^{31}$ ).

$\mathrm{Na}$ visão das pessoas que o celebraram, Zdan disse o que muitos gostariam de ter dito nos últimos quatro anos aos seguidores de Donald Trump e ao próprio presidente, responsável por hostilizar o trabalho da imprensa e propagar notícias falsas durante seu mandato ${ }^{32}$. Zdan mostrou que, antes de ser repórter, ele também é um ser humano com emoções que podem levá-lo a ações imprevistas e, inevitavelmente, incoerentes segundo a noção de imparcialidade preconizada historicamente como um valor da prática jornalística.

Conscientes há mais tempo do papel das emoções nas decisões das pessoas, as Big Techs investem pesado em estudos sobre o comportamento humano para entender as suas motivações (BRIDGER, 2020). Os mecanismos que permitem a maximização dos lucros de seus serviços oferecidos aos anunciantes têm causado sérios problemas relativos à privacidade dos usuários, como vimos no tópico 1.1.1. Se

\footnotetext{
30 Uma vez postado no TikTok, o conteúdo do vídeo é analisado pelos algoritmos de inteligência artificial da plataforma e, dependendo da relevância, ele é espalhado para mais pessoas, que são, inclusive, incentivadas pela própria empresa a compartilharem em outras redes sociais também, já que os vídeos virais são um "princípio fundamental" da empresa chinesa (CAMILLO, 2020) ${ }^{30}$

31 "Emotion drives people's increasingly intimate relationships with technology, fuels engagement with news and information, and inspires professionals to pursue careers in an industry that offers anything but reliable rewards for work well done. It inspires connection."

32 Falaremos com mais profundidade do assunto no item 1.2.1 a seguir.
} 
juntarmos isso ao fato de que as emoções servem de motor e gatilho para o compartilhamento de desinformação pelas mídias sociais (SANTAELLA, 2019), teremos o cenário de aparente "dominação das máquinas". Contudo, as empresas jornalísticas, enquanto clientes das plataformas, também são parte do problema e começaram, nos últimos anos, a perceber isso.

Nessa segunda década do século XXI, vivemos em um contexto social e político em que as próprias figuras de autoridade se mostram levianamente interessadas em negar a realidade (figura 1.6).

Figura 1.6 - Donald Trump alega vitória nas eleições de 2020. As publicações foram marcadas pelo Twitter como "alegações não baseadas em fatos".

\begin{tabular}{|c|c|c|c|c|}
\hline \multicolumn{5}{|c|}{$\begin{array}{l}\text { Donald J. Trump @realDonaldTrump·4h } \\
\text { 71,000,000 Legal Votes. The most EVER for a sitting President! }\end{array}$} \\
\hline$Q_{287 \mathrm{Mil}}$ & $\uparrow \beth_{167 \mathrm{Mil}}$ & O549Mil & ↔ & \\
\hline \multicolumn{4}{|c|}{ Donald J.Trump @ @realDonaldTrump.4h } & $\cdots$ \\
\hline \multicolumn{5}{|c|}{ THE OBSERVERS WERE NOT ALLOWED INTO THE COUNTING } \\
\hline \multicolumn{5}{|c|}{ ROOMS. I WON THE ELECTION, GOT 71,000,000 LEGAL VOTES. BAD } \\
\hline \multicolumn{5}{|c|}{ THINGS HAPPENED WHICH OUR OBSERVERS WERE NOT ALLOWED } \\
\hline \multicolumn{5}{|c|}{$\begin{array}{l}\text { TO SEE. NEVER HAPPENED BEFORE. MILLIONS OF MAIL-IN BALLOTS } \\
\text { WERE SENT TO PEOPLE WHO NEVER ASKED FOR THEM! }\end{array}$} \\
\hline \multicolumn{4}{|c|}{ (?) This claim about election fraud is disputed } & $>$ \\
\hline$Q_{215 \mathrm{Mil}}$ & 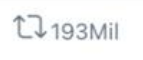 & $O_{416 \mathrm{Mil}}$ & ^ & \\
\hline \multicolumn{4}{|c|}{$\begin{array}{l}\text { Donald J. Trump @ @realDonaldTrump·10h } \\
\text { I WON THIS ELECTION, BY A LOT! }\end{array}$} & $\cdots$ \\
\hline \multicolumn{4}{|c|}{$\begin{array}{l}\text { (?) Official sources may not have called the race when this } \\
\text { was Tweeted }\end{array}$} & $>$ \\
\hline$Q_{929 \mathrm{Mil}}$ & 饣】838Mil & $O_{1 \mathrm{Mi}}$ & ^ & \\
\hline
\end{tabular}

Foto: captura de tela da autora (2020)/ reprodução via Twitter

Como veremos a seguir, dentro do ambiente das plataformas digitais, muita coisa foge do controle dos jornalistas e dos demais profissionais da cadeia produtiva de notícias, principalmente quando o assunto é a disseminação de informações falsas. Sendo assim, o caminho para o equilíbrio no relacionamento entre plataformas, jornais e audiência passa, fundamentalmente, pelo entendimento dos fatores que influenciam a sua convivência no ecossistema de comunicação contemporâneo. 


\subsubsection{O DESAFIO DO JORNALISMO CONTRA AS FAKE NEWS}

A partir da década de 1990, com a amplificação do acesso à Internet e aos meios de produção midiáticos, o público em geral passou a atuar também como produtor de informações, desbancando o monopólio dos conglomerados de mídia. Nos anos 2000, os blogs e fóruns de discussão online foram os primeiros ambientes a oferecer a possibilidade de publicação sem a necessidade do conhecimento de códigos complexos de computação (BORGES, 2007). Com isso, o papel do jornalismo profissional passou a ser desafiado pela oferta de conteúdo informativo paralelo, que carregava em si o potencial de gerar conversas e compartilhamentos na Internet.

Com o surgimento das plataformas digitais de mídias sociais, a quantidade de pessoas gerando informações online começou a sedimentar a desmediatização da sociedade (HAN, 2018). Sem a necessidade do intermediário, ou seja, dos meios de comunicação tradicionais como a televisão e os jornais, as pessoas começaram a ter autonomia para criar suas próprias contribuições no ambiente digital e para distribuílas para suas redes de contatos.

\footnotetext{
Hoje não somos mais destinatários e consumidores passivos de informação, mas sim remetentes e produtores ativos. Não nos contentamos mais em consumir informações passivamente, mas sim queremos produzi-las e comunicá-las ativamente nós mesmos. Somos simultaneamente consumidores e produtores. Esse duplo papel aumenta enormemente a quantidade de informações. A mídia digital não oferece apenas uma janela para 0 assistir passivo, mas sim também portas através das quais passamos informações produzidas por nós mesmos. (HAN, 2018, p. 36)
}

De acordo com o conceito de desmediatização, apresentado pelo filósofo Byung-Chul Han (2018), encerra-se a época da representação porque, hoje, todos querem "estar eles mesmos diretamente presentes e apresentar a sua opinião sem intermediários" (HAN, 2018, p. 37, grifos do autor). Dessa forma, o ecossistema de comunicação atual permite e estimula a propagação de opiniões e informações por meio das mídias sociais.

Além do jornalismo, a partir do final do século XX outras instituições passaram a viver momentos conturbados também. Manifestações populares contra governos totalitários e corruptos se espalharam pelo mundo, tomando as ruas a favor da democracia e da liberdade de expressão. Com o mundo passando por instabilidades econômicas e políticas, especialmente depois da crise financeira global na primeira 
década do século XXI, o avanço das tecnologias e das comunicações adicionou velocidade às mudanças de uma forma nunca antes vista. O protagonismo dos smartphones impulsionou a organização e a divulgação dos movimentos sociais graças às redes de contatos fortalecidas pelas plataformas digitais de mídias sociais. A oferta de recursos de mobilização e interatividade contribuíram ainda mais para o desgaste da ideia de representatividade oferecida pelos modelos atuais de governo, levando a desmediatização também para o campo da política.

Ela [a desmediatização] ameaça a democracia representativa. Os representantes políticos apresentam-se não como transmissores, mas sim como barreiras. Assim, a desmediatização se manifesta como exigência por mais participação e transparência. (HAN, 2018, p. 38)

Ao mesmo tempo, um outro fenômeno começou a ganhar espaço: o aumento da polarização acompanhada da radicalização de opiniões movidas por diversas ideologias, entre elas o nacionalismo e o conservadorismo. Segundo Andreassa (2020), a polarização é um aspecto que faz parte da natureza humana. Como espécie, nossos ancestrais formavam grupos para se proteger e para se manter neles era preciso demonstrar lealdade e confiança aos outros membros. Naquela época, isso era uma ferramenta de sobrevivência, mas hoje o excesso de polarização pode ser prejudicial principalmente à democracia, pois "em uma sociedade centrada em dois lados radicalizados, adversários são vistos como inimigos, o diálogo não é incentivado - ou mesmo é condenado - e transgredir as regras parece justificável" (ANDREASSA, 2020, online).

No meio de tudo isso, a produção e a disseminação de informações falsas se multiplicaram. A expressão fake news (notícia falsa, em inglês) se popularizou e virou sinônimo de desinformação. Trata-se de um conteúdo com aparência de notícia, mas que não passa pelos critérios que balizam a prática jornalística, tais como os de ética, de apuração e de compromisso com a veracidade dos fatos, ou seja, um conteúdo criado e espalhado muitas vezes por motivações políticas ou econômicas, a fim de "manipular atitudes, opiniões e ações" (SANTAELLA, 2019, p. 33).

Apesar de a propagação de mentiras e informações incorretas não ser um fenômeno exclusivo da nossa época e de ser um artifício já usado pela humanidade em outros momentos da história (HARARI, 2018), a multiplicação de plataformas 
digitais e de smartphones acelerou o ritmo de compartilhamento desse tipo de conteúdo nas redes sociais.

O ápice das discussões sobre as fake news se deu a partir de 2016, após a vitória do candidato republicado Donald Trump nas eleições à presidência, nos Estados Unidos. Um esquema de manipulação de eleitores veio à tona, graças a uma extensa investigação que uniu três jornais - The Observer, The Guardian e The New York Times - à publicação simultânea de uma mesma reportagem, que revelava as irregularidades da empresa de consultoria Cambrigde Analytica (CA), contratada pela campanha de Trump. A partir do tratamento de dados obtidos sem o consentimento de eleitores que possuíam conta no Facebook, a Cambridge Analytica formou um gigantesco banco com informações a respeito das tendências políticas de cada um e do quão suscetível à manipulação essas pessoas seriam:

\begin{abstract}
A CA rotulou esses perfis de usuários como the persuadables (os persuadíveis). A empresa também fazia uso da rede social Facebook com a prática de ataques-focais (microtargeting, em inglês) de seus usuários, muitas vezes utilizando-se - de forma intencional - de notícias falsas (Fake News) para manipular tendências políticas de eleitores, resultando em uma ruptura da democracia e gerando, de forma deliberada, uma sociedade polarizada. (FORNASIER; BECK, 2020, p. 184, grifos dos autores)
\end{abstract}

O crescimento do descrédito nas instituições e a desconfiança na estabilidade que elas ofereciam à sociedade faz parte de um fenômeno maior, conhecido como Pós-verdade. O conceito de pós-verdade também não é uma novidade do século XXI, assim como o de fake news. O Dicionário de Oxford, publicação de renome que elege anualmente a palavra ou a expressão que mais capta o momento vivido pela humanidade, escolheu "pós-verdade" como a palavra internacional de 2016, principalmente porque a sua frequência de uso cresceu exponencialmente naqueles últimos doze meses (figura 1.7). Na ocasião, o Dicionário mostrou que esse termo já tinha sido usado há algumas décadas, com destaque para um texto de 1992 do escritor Steve Tesich, na revista The Nation ${ }^{33}$, no qual se referia ao escândalo do Irã e da Guerra do Golfo.

${ }^{33}$ A história completa é contada em: https://languages.oup.com/word-of-the-year/2016/ 


\section{OCORRÊNCIAS DA PALAVRA "PÓS-VERDADE"}

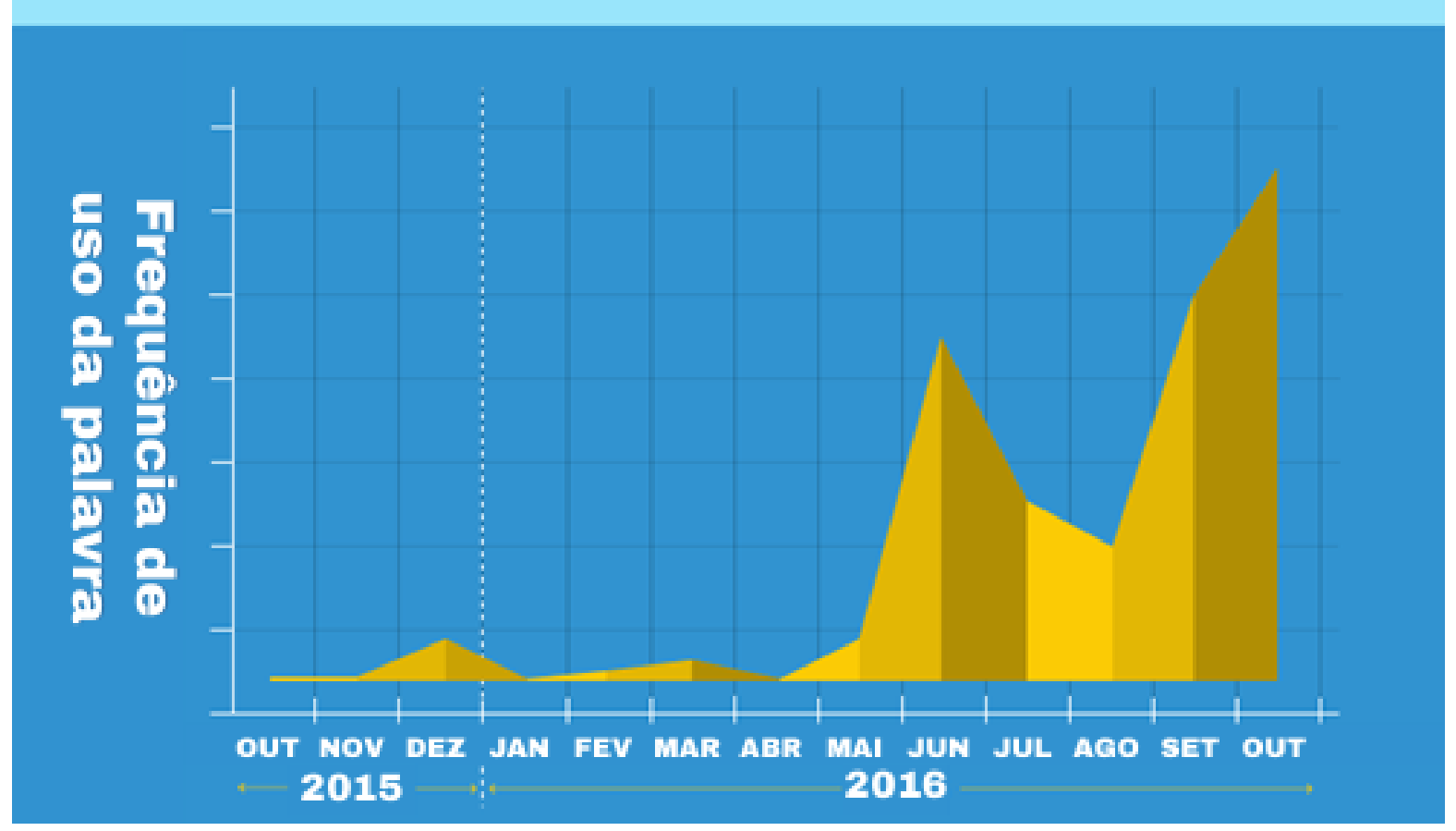

Fonte: adaptado para o português a partir de POST-TRUTH, 2016

Para deixar claro o significado tomado pelo Dicionário na escolha da expressão, a publicação explica que a palavra pós-verdade apresenta dois sentidos diferentes. O primeiro é "depois que a verdade tenha se tornado conhecida", no qual o prefixo "pós" indica "depois de um evento ou situação específica", como, por exemplo, na expressão "pós-operatório". O segundo significado foi inaugurado pelo escritor Tesich, que utilizou o conceito para mostrar que a verdade, em si, tornou-se irrelevante, não sendo mais importante. A publicação, portanto, escolheu a expressão pós-verdade justamente por esse último significado (POST-TRUTH, 2016). Com o aumento da incidência do problema, no ano seguinte, em 2017, o Dicionário Oxford escolheu fake news como a palavra do ano.

Em seu livro "A Pós-verdade é verdadeira ou falsa?", a pesquisadora Lucia Santaella defende que é essencial pensar esse fenômeno também observando a avalanche de mentiras disseminadas por meio das plataformas digitais, pois esse é 
um diferencial da atual Pós-verdade 34 : "mentiras repetidas, compartilhadas e comentadas milhões de vezes dissolvem todas as fronteiras que as separam de uma possível verdade" (SANTAELLA, 2019, p. 51).

Outro aspecto da Pós-verdade é o fortalecimento de opiniões pessoais em detrimento de fatos. A ciência e o jornalismo, como um todo, têm sido alvos de campanhas com o objetivo de levar tais setores da sociedade ao descrédito e de incitar a desconfiança do público perante as suas atuações. O pesquisador Rogério Christofoletti (2019) aponta os principais fatores que contribuíram para a crise do jornalismo profissional: a economia da gratuidade ${ }^{35}$ na Internet, a entrada no mercado de produtores de notícias amadores e sem formação jornalística, as regras arbitrárias das plataformas digitais (comandadas por algoritmos muitas vezes desconhecidos), o desvio de sua função pública e o abandono do papel social junto à população.

\begin{abstract}
A desconfiança ocupou o lugar das certezas e esgarça o tecido social feito à base das relações de pactos diários. Período de intensas transições tecnológicas e de fortes transformações culturais tendem a agudizar as incertezas, alimentando a sensação de crise em todas as partes. Habitamos uma paisagem como esta, onde tudo parece estar fora da ordem ou com funcionamento comprometido. O jornalismo não escapa dessa crise de confiança. Como ele é dessas atividades que se ocupam de organizar sentidos, como disputar atenção num mundo tão barulhento como nosso? Como ser aceito e merecer a confiança das pessoas? O jornalismo ainda pode ocupar esse lugar de intermediário entre os fatos e as pessoas? (CHRISTOFOLETTI, 2019, p. 60)
\end{abstract}

Algumas das perguntas colocadas por Christofoletti (2019) foram parcialmente respondidas em 2020. O trabalho jornalístico e científico passou por um onda de revalorização durante a pandemia do novo coronavírus, que começou no final de $2019^{36}$. As muitas fake news sobre o avanço da doença e sobre a forma correta de prevenção compartilhadas nas plataformas de mídias sociais mostraram que a apuração dos jornais e das agências de checagem é essencial para organizar o caos informacional.

Para promover o amplo acesso da população à cobertura jornalística com informações responsáveis, diversos jornais, canais televisivos e revistas abriram seus

\footnotetext{
34 Levando em consideração as informações dispostas, usaremos letras iniciais maiúsculas para nos referir à palavra a fim de diferenciá-la de outros significados de pós-verdade.

${ }_{35} \mathrm{Na}$ economia da gratuidade o próprio usuário costuma ser o produto, já que existe troca de dados pessoais por serviços.

${ }^{36}$ E que ainda continua, em outubro de 2020, enquanto escrevemos essa dissertação. Atualização 1: E em novembro, enquanto a revisamos. Atualização 2: E em janeiro de 2021, enquanto a corrigimos.
} 
conteúdos para não-assinantes e, naqueles já disponíveis de forma aberta, estendeuse a cobertura jornalística para além do habitual.

O Estadão e a Folha ${ }^{37}$ retiraram temporariamente o paywal/38 das principais reportagens sobre o coronavírus. No Instagram, o perfil do Estadão compartilhou stories diários que informavam essa iniciativa (figura 1.8) e a Folha disponibilizava no próprio story um resumo das principais notícias sobre o assunto (figura 1.9).

Figuras 1.8 e 1.9 - Stories com informações sobre o coronavírus

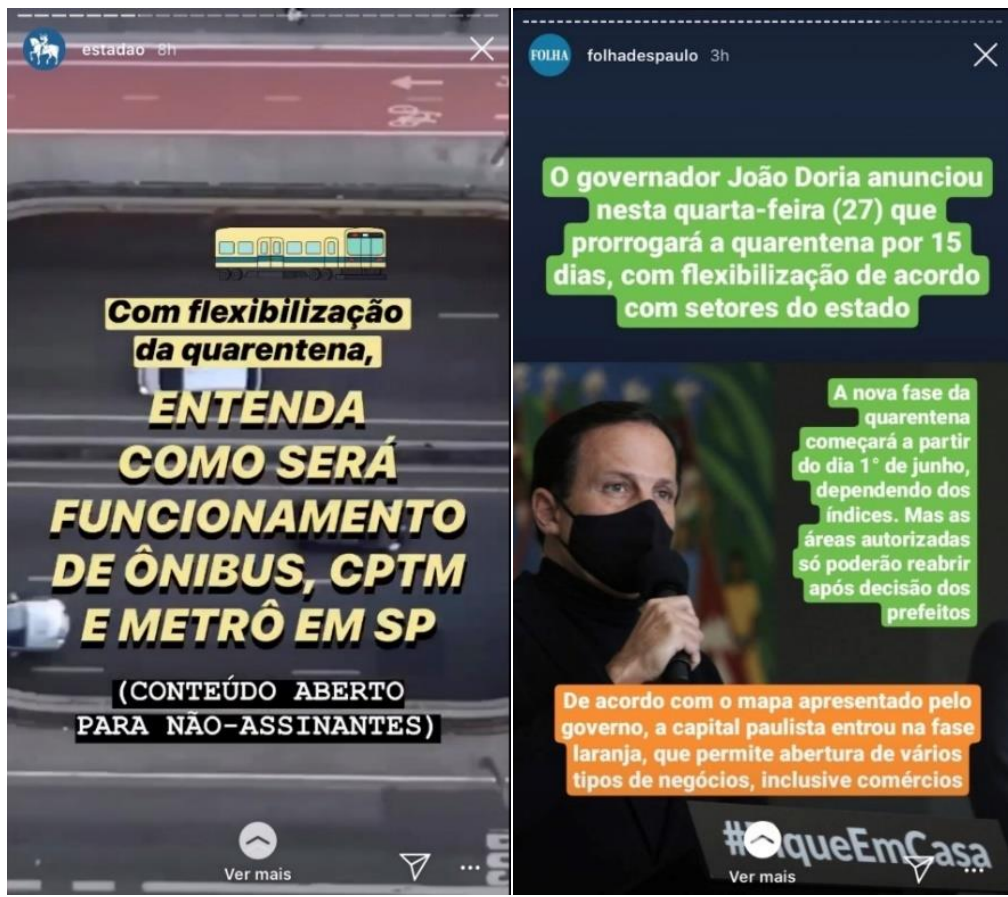

Fonte: captura de tela feita pela autora/Reprodução Instagram Estadão e Folha

Em março de 2020, Mariana Mandelli, coordenadora de comunicação do Instituto Palavra Aberta ${ }^{39}$, publicou em sua coluna no site da Folha dados a respeito do aumento da preocupação com boatos sobre a doença que espalhavam o pânico e colocavam em risco a vida das pessoas.

Segundo Mandelli (2020), cresceu a procura por informações no jornalismo profissional durante esse período. A autora destacou que os programas jornalísticos das emissoras de televisão e os jornais impressos foram as fontes com maior índice de confiança na opinião das pessoas.

${ }^{37}$ Os Stories do Estadão e da Folha serão abordados em profundidade nos capítulos 2 e 3.

38 O paywall é um "muro" metafórico adotado em sites jornalísticos, que funciona como barreira e bloqueia a visualização das notícias na íntegra, a não ser que o leitor assine um dos planos oferecidos para acessar o conteúdo.

${ }^{39} \mathrm{O}$ instituto Palavra Aberta promove ações educativas contra a desinformação. 
É justamente essa responsabilidade, unida à credibilidade e à busca pela imparcialidade, que precisa ser reforçada perante a sociedade brasileira, incluindo crianças e jovens. Se não orientarmos desde cedo, dentro e fora da escola, as camadas mais jovens da população a filtrarem informações, checarem dados e a enxergarem valor no jornalismo profissional, que tipo de cidadãos teremos em uma eventual pandemia no futuro, com potencial ainda mais drástico? (MANDELLI, 2020, online)

O prognóstico de especialistas é que a desinformação poderá começar a ser contida pela Geração Z (os nascidos entre 1995 e 2010). Diversas pesquisas estão em curso para entender como a nova geração consome notícias. Dentre as mais recentes, destaca-se a da HSR Specialist Researchers, divulgada em setembro de 2020. O estudo buscou rastrear como os jovens brasileiros estavam se sentindo durante a pandemia e que hábitos novos se desenvolveram nesse período.

As redes sociais online ainda são a principal fonte de informações para eles, com o Instagram sendo a plataforma principal para $70 \%$ deles. Cerca de $55 \%$ responderam que estão acompanhando notícias por portais de jornais, número que ficou acima dos que se informam mais pelo WhatsApp (43\%) ou pelo Facebook (40\%) (DELBONI, 2020, online).

Outra pesquisa, dessa vez dos Estados Unidos, realizada pela College Reaction, que estuda comportamentos de jovens universitários, trouxe resultados positivos ao cenário global de desinformação. Apesar de $83 \%$ dos universitários receberem a maioria das notícias por meio de mídias sociais ou sites de notícias online, apenas $7 \%$ acreditam que suas redes sociais digitais compartilham conteúdo de credibilidade. Mais da metade disse que sites de jornais impressos ou de outros meios de comunicação jornalísticos são mais confiáveis (KIGHT, 2020, online).

Apesar do otimismo transmitido pelas pesquisas, é preciso cautela ao colocar o peso da resolução das fake news no ombro dos jovens. A ideia de que eles teriam um poder cognitivo acima das gerações anteriores para lidar com a tecnologia e entender as suas funcionalidades, a partir da retórica dos nativos digitais, coloca em risco uma camada da população que ainda está desenvolvendo suas habilidades cognitivas para lidar com o mundo. Para a pesquisadora danah boyd ${ }^{40}$ (2014), que estuda o comportamento dos jovens nas mídias sociais, essa visão além de imprecisa, é perigosa, pois:

${ }^{40}$ A própria pesquisadora assina seu nome com letras minúsculas por uma decisão pessoal e política. Para saber mais: http://www.danah.org/name.html . 
[...] ela permite que alguns evitem a responsabilidade de ajudar jovens e adultos a navegar em um mundo conectado. Se encararmos as habilidades e o conhecimento como inerentemente geracionais, então os esforços organizados para alcançar as formas necessárias de alfabetização são desnecessários. Em outras palavras, o foco nos jovens de hoje como nativos digitais pressupõe que tudo o que nós, como sociedade, precisamos fazer é sermos pacientes e esperarmos que essa geração de prodígios digitais cresça. É improvável que uma atitude de laissez-faire erradique as desigualdades que continuam a surgir. Da mesma forma, essas atitudes não permitirão que os jovens comuns sejam participantes da Internet mais aprimorados. (BOYD, 2014, p. 197, tradução nossa ${ }^{41}$ ).

A preocupação com a orientação de jovens e crianças para que eles saibam se defender das fake news ressalta a importância de olharmos para os novos formatos de produção e consumo de notícias, principalmente no ambiente mais frequentado por esse público na atualidade: as plataformas digitais de mídias sociais.

\subsubsection{REINVENTANDO AS FORMAS DE PRODUZIR E DE CONSUMIR NOTÍCIAS}

A pesquisa anual feita pelo Comitê Gestor da Internet no Brasil (CGI.br) mostrou que, em 2019, 68\% das crianças e adolescentes brasileiros de 9 a 17 anos usaram as redes sociais online regularmente (TIC KIDS ONLINE BRASIL, 2020). Esse número sobe para $91 \%$ se considerarmos só a faixa de 15 a 17 anos. Somado a esse dado, temos também o aspecto móvel e multiplataforma do consumo de mídia desse público, já que a forma de acesso à Internet é feita via telefone celular em $95 \%$ dos casos. Outra análise, realizada a nível global, mostra que jovens de 18 a 24 anos têm duas vezes mais chances de preferir receber notícias pelas plataformas de mídias sociais, de acordo com o relatório Digital News do Reuters Institute (2020).

A respeito do Instagram, a mesma publicação mostrou que a plataforma teve um crescimento significativo de 2018 para 2019: em todas as faixas etárias, o seu uso para notícias dobrou e, no Brasil, 30\% dos usuários usam a plataforma para se atualizarem sobre o mundo (DIGITAL NEWS REPORT, 2020). Mais uma pesquisa confirma essa tendência, dessa vez conduzida por uma empresa de consultoria

\footnotetext{
41 "Because of how society has politicized this language, it allows some to eschew responsibility for helping youth and adults navigate a networked world. If we view skills and knowledge as inherently generational, then organized efforts to achieve needed forms of literacy are unnecessary. In other words, a focus on today's youth as digital natives presumes that all we as a society need to do is be patient and wait for a generation of these digital wunderkinds to grow up. A laissez-faire attitude is unlikely to eradicate the inequalities that continue to emerge. Likewise, these attitudes will not empower average youth to be more sophisticated internet participants."
} 
especializada em redes sociais, a Socialbakers. Em 2020 houve uma alta na procura de informações em perfis jornalísticos no Instagram, demonstrado por meio do crescimento em $74 \%$ do engajamento ${ }^{42}$ em postagens de jornais e revistas desde 0 início da pandemia do novo coronavírus (VITORIO, 2020).

Nos últimos anos, a produção e o consumo de conteúdo em áudio também vêm se intensificando. De acordo com o relatório Digital News (2020), os podcasts são um importante canal para as marcas jornalísticas construírem lealdade junto à audiência. Com um formato que permite discussões mais aprofundadas sobre os mais diversos temas da sociedade, os podcasts fazem sucesso principalmente entre pessoas que buscam informações com mais contexto. O público é, em sua maioria, formado por jovens adultos (18 a 34 anos), e o consumo se dá principalmente via fones de ouvido e smartphones, indicando a relação que mídias exclusivamente sonoras possuem com pessoas em deslocamento ou enquanto realizam outras atividades. Nos Estados Unidos, por exemplo, cerca de 59\% dos ouvintes gostam do formato porque ele permite um entendimento maior sobre questões complexas e, para $57 \%$, oferecem uma perspectiva mais ampla do que outras mídias (DIGITAL NEWS REPORT, 2020).

O "Café da manhã", podcast publicado de segunda à sexta pela Folha na plataforma de streaming Spotify é um exemplo de uso jornalístico desse tipo de formato para a contextualização de temas em alta. Em maio de $2020^{43}$, o programa abordou a iniciativa Sleeping Giants que atua expondo para o público no Twitter marcas que possuam anúncios em sites que distribuem fake news. O movimento, que começou nos Estados Unidos, chegou ao Brasil dias antes, quando foi criado na plataforma Twitter um perfil direcionado à cobertura local.

$42 \mathrm{O}$ conceito de engajamento, quando ligado ao mundo corporativo, está ligado às estratégias de marketing social e de comunicação organizacional com "estratégias empresariais para obter vantagem competitiva em um ambiente mercadológico de forte concorrência" (BASTOS, 2018, p. 9).

43 Os exemplos de stories apresentados nesse tópico foram obtidos durante a semana de coleta de documentos para a nossa análise exploratória, que será discutida no item 1.3 e no capítulo 2. 
Pressionadas por iniciativas como a Sleeping Giants e a ameaça organizada de boicote "Stop Hate for Profit" 44 , essa última encabeçada por grandes empresas anunciantes, as plataformas de mídias sociais passaram a criar estratégias para apagar um incêndio que elas próprias ajudaram a começar.

No caso do Instagram, em março de 2020 a plataforma chamou a atenção ao tirar do ar um vídeo da conta oficial do atual presidente brasileiro, Jair Bolsonaro, por conter informações nocivas e potencialmente perigosas. Nas imagens, o político aparecia fazendo um passeio e criando aglomerações por onde passava em plena crise do coronavírus e após o então ministro da Saúde, Luiz Henrique Mandetta, recomendar que as pessoas respeitassem a quarentena e o isolamento social (MARQUES, 2020). Na época, Bolsonaro afirmou que a COVID-19 tratava-se apenas de uma "gripezinha" (VANNUCHI, 2020, online).

Não é de hoje que a Pós-verdade apresenta graves reflexos no Brasil. Em 2018, durante a campanha à presidência do então candidato Jair Bolsonaro, as redes sociais foram inundadas com informações falsas e ataques a seus adversários, principalmente pela plataforma WhatsApp e, agora, averigua-se o quanto isso tenha influenciado nos resultados das eleições brasileiras. O Supremo Tribunal Federal (STF) investiga a existência de um "gabinete do ódio", um grupo ligado ao Planalto que comandaria uma rede de fake news (MELLO, 2020). A imprensa brasileira tem publicado, desde as primeiras ocorrências, reportagens especiais sobre o assunto, denunciando os envolvidos e acompanhando as investigações do STF e também da Comissão Parlamentar Mista de Inquérito (CPMI) das fake news.

O assunto foi amplamente divulgado e discutido nas mídias sociais. No final de maio de $2020^{45}$ houve o cumprimento de mandatos de busca e apreensão pela Polícia Federal contra suspeitos de envolvimento no esquema das fake news no Planalto. Devido à alta relevância do assunto, principalmente para o ambiente de plataformas de mídias sociais em que circulam a desinformação, tanto a Folha (figuras 1.10 e 1.11), quanto o Estadão (figuras 1.12 e 1.13), divulgaram a cobertura

\footnotetext{
44 A campanha "Stop Hate for Profit" ("Chega de ódio pelo lucro") começou nos Estados Unidos com algumas das maiores marcas do planeta forçando o Facebook a adotar políticas mais rígidas de controle de discursos de ódio, abarcando também o combate às fake news. A campanha nasceu na esteira das manifestações por justiça racial nos Estados Unidos após o assassinato de George Floyd em uma abordagem por um policial branco. Para saber mais: https://olhardigital.com.br/noticia/boicotede-anunciantes-coloca-facebook-em-risco-e-finalmente-pressiona-zuckerberg/102875

${ }^{45}$ Período que coincidiu com a semana de coleta dos stories nos perfis dos jornais analisados.
} 
jornalística dessa ação em seus stories, contextualizando o leitor a respeito do inquérito e de como isso poderia influenciar o cenário político (figura 1.14).

Figuras 1.10 e 1.11 - Cobertura nos stories da Folha de operação da Polícia Federal
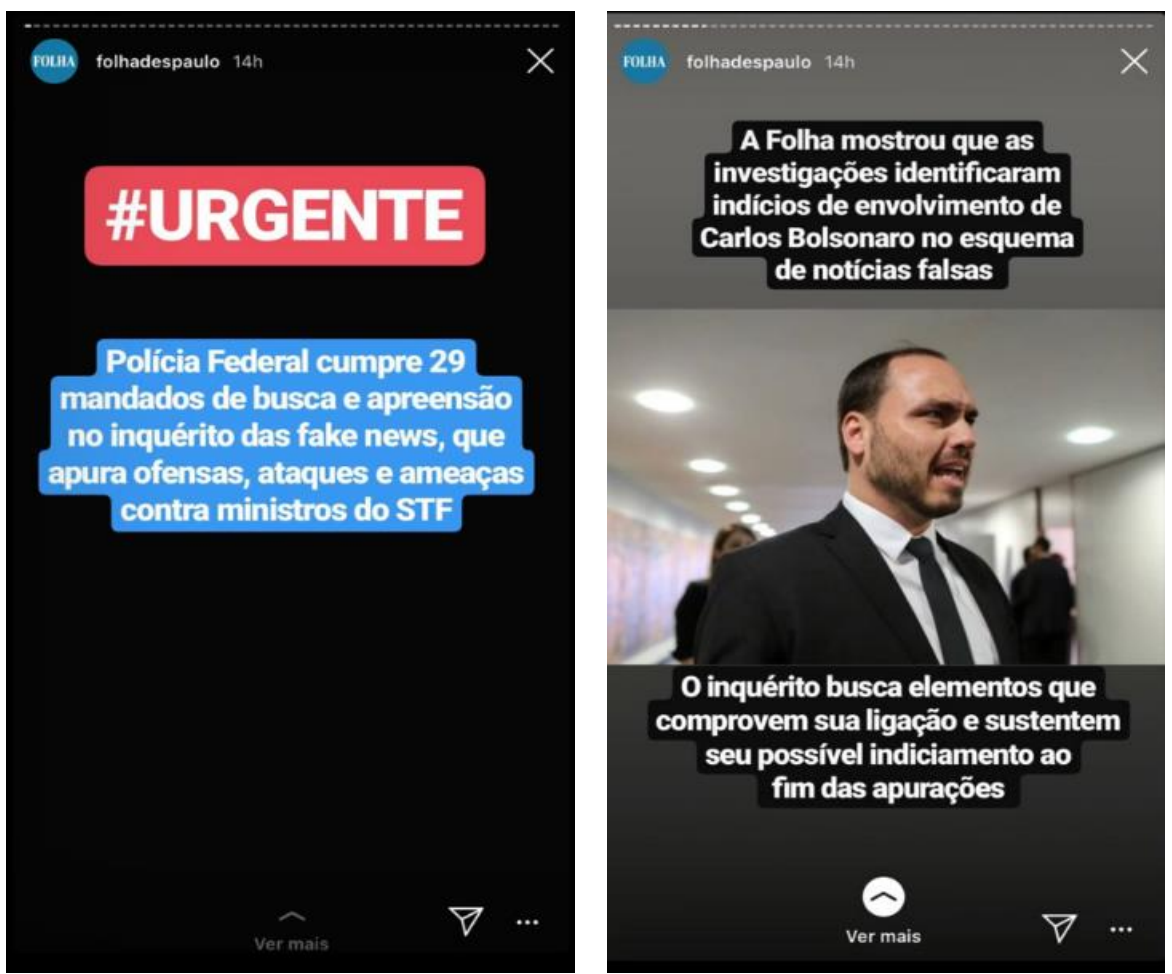

Fonte: captura de tela feita pela autora (2020)/ reprodução Instagram Stories da Folha

Figuras 1.12, 1.13 e 1.14 - Cobertura nos stories do Estadão de operação da Polícia Federal
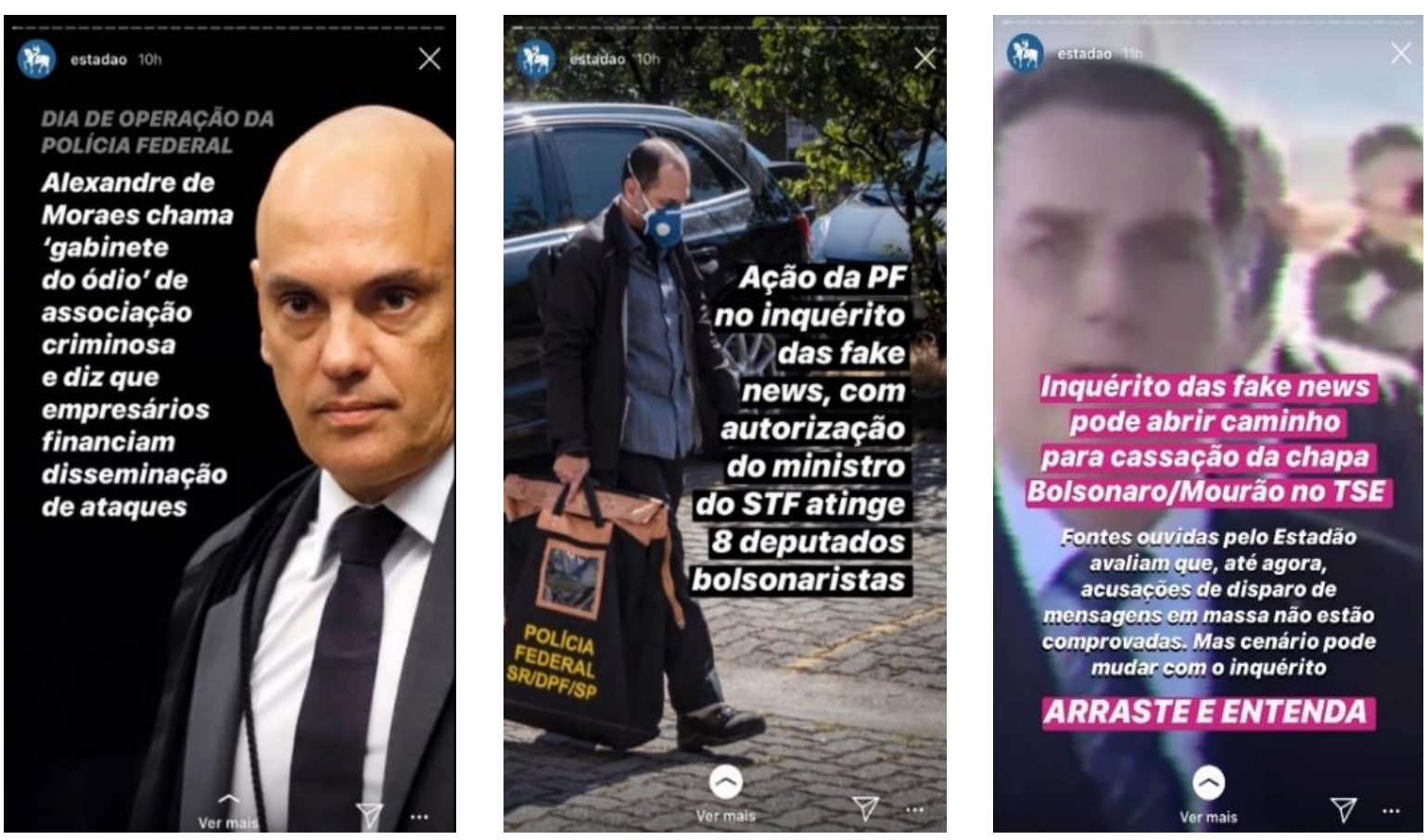

Fonte: captura de tela feita pela autora (2020)/ reprodução Instagram Stories do Estadão 
O avanço da desinformação tem se tornado assunto recorrente nos stories dos jornais. Ainda em maio, o perfil do Estadão no Instagram publicou uma notícia desmentindo uma informação falsa que circulou na Internet sobre Felipe Neto, influenciador digital brasileiro que possui uma das maiores bases de seguidores em redes sociais online, formada principalmente por crianças e jovens. Depois de fazer críticas a Bolsonaro em suas redes e para a mídia internacional, o youtuber foi vítima de uma intensa onda de ataques e de fake news que o acusavam de fazer apologia à pedofilia (AGUIAR, 2020).

Figura 1.15 - Story do Estadão desmentindo fake news envolvendo Felipe Neto

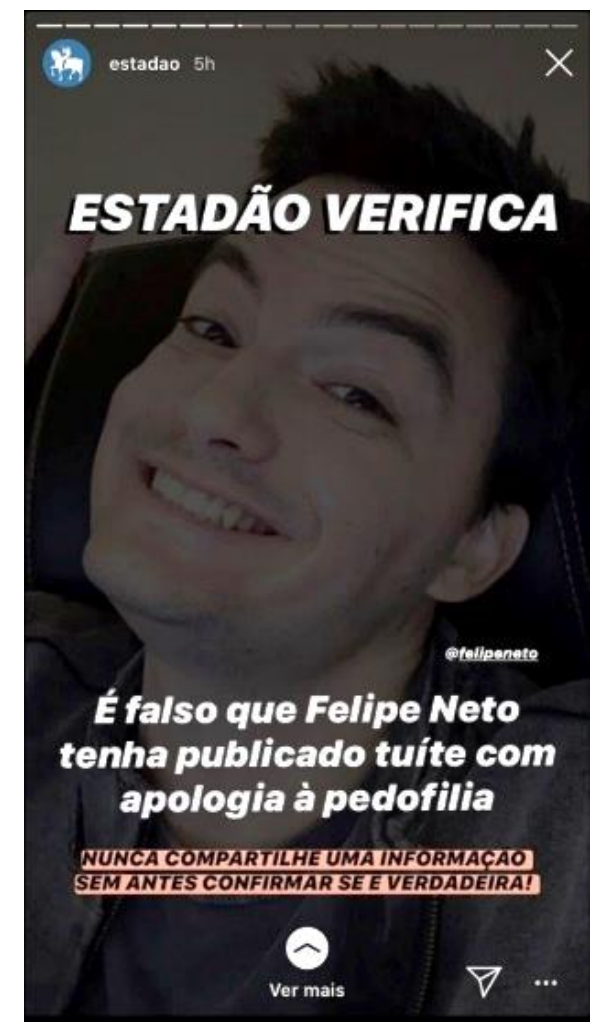

Fonte: captura de tela feita pela autora (2020)/ reprodução Instagram Stories do Estadão

O blog Estadão Verifica, do site do jornal, agrupa checagens de notícias e desmente boatos que circulam pela Internet. Assim como ele, atualmente existem muitas outras iniciativas jornalísticas no Brasil e no mundo fazendo o chamado factchecking - expressão em inglês para checagem de fatos -, que se tornou essencial para revelar notícias e declarações de políticos e autoridades com informações equivocadas ou mal intencionadas (SANTAELLA, 2019).

"Notícias falsas, estratégias sofisticadas de desinformação, manipulações políticas, descrédito da verdade e sequestro da legitimidade social corroem os 
alicerces do jornalismo como forma de conhecimento e como prática social", resume Christofoletti (2019, p. 93). As duas primeiras décadas do século XXI não foram brandas com o jornalismo e, muito menos, com a democracia. Mas ainda há estratégias que podem contribuir para o combate às fake news e a todo esse cenário de desinformação. Segundo o Christofoletti (2019), a crise do jornalismo afeta a todos:

Sua natureza é multidimensional, e sua complexidade exige o enfrentamento efetivo, imediato, contínuo e cooperado. Ainda é possível acreditar no jornalismo, mas essa credibilidade necessita de novos pactos, de maior abertura e transparência, de mais comprometimento comunitário e social. (CHRISTOFOLETTI, 2019, p. 95).

As características da crise expostas pelo autor nos levam a defender uma solução que não seja simplista ou reducionista. Nesse trabalho, usamos como base a abordagem sistêmica de Bertocchi (2016), que define narrativa digital jornalística como um sistema, um processo, um fluxo. Como sistema, ela passa a carecer de uma visão global de todos os envolvidos e de todo o seu entorno, processo que veremos em mais detalhes no segundo capítulo.

A seguir, trataremos da construção do processo metodológico para a exploração da presença jornalística nos Stories do Instagram. 


\subsection{A JORNADA METODOLÓGICA DE EXPLORAÇÃO DOS STORIES}

A importância do Instagram para conectar pessoas às empresas de jornalismo atualmente é indiscutível. Não à toa, a Folha e o Estadão, os jornais analisados nesse trabalho, fazem publicações diárias na plataforma, tanto no espaço de imagens permanentes - a galeria de fotos -, como no espaço temporário dos Stories. O Instagram, com seu forte apelo imagético e com informações que podem ser consumidas em curto espaço de tempo, possui um grande potencial para a aproximação de consumidores mais novos. Além de divulgarem notícias que levam aos seus sites, as empresas também aproveitam a ferramenta de hiperlink dos Stories para promover outros formatos de conteúdo jornalístico, como podcasts e lives.

Para contextualizar a escolha da metodologia e entender as peculiaridades do percurso de análise, traremos a seguir um panorama das pesquisas nacionais realizadas em mídias sociais efêmeras e as razões para termos adotado a análise de conteúdo (BARDIN, 2016) como instrumento metodológico.

Detalharemos também, nos próximos tópicos, a preparação para as etapas da nossa jornada exploratória a fim de caracterizar a presença da Folha e do Estadão nesse ambiente. $O$ estudo de publicações em mídias sociais efêmeras se efetivou, como veremos, por meio do desenvolvimento de uma metodologia adaptada de análise de conteúdo para o universo dos Stories.

\subsubsection{A PESQUISA ACADÊMICA EM MÍDIAS SOCIAIS EFÊMERAS}

A proliferação das mídias sociais no ambiente digital deu aos cientistas um ambiente fértil para análises de grandes volumes de informação, com o surgimento de técnicas e metodologias para a interpretação de big data. No entanto, no caso das mídias sociais efêmeras (BAYER et al, 2016), uma característica elementar de sua constituição coloca no caminho do investigador um obstáculo: a sua efemeridade. Depois de 24 horas, os dados desaparecem automaticamente, ao contrário das mídias permanentes, que armazenam suas informações por tempo indeterminado, o que torna difícil a coleta integral de conteúdo pelos pesquisadores (XU et al, 2016).

Dentre as fragilidades do objeto a serem superadas pelos pesquisadores, além do aspecto temporário das postagens, existe também a instabilidade da 
plataforma no qual ele se insere, já que o Instagram faz atualizações constantes em suas funcionalidades, com a adição e remoção de recursos de forma imprevisível. Assim, precisávamos de uma metodologia de pesquisa que possibilitasse a sua exploração de maneira abrangente e com maior flexibilidade de técnicas, tendo em mente as peculiaridades desse tipo de mídia. Todas essas preocupações, de ordem logística e operacional, influenciaram o nosso processo de investigação.

Ao nos deparamos com as principais descobertas e os desafios encontrados por outros pesquisadores, localizamos alguns estudos brasileiros que apresentam conclusões pertinentes para a discussão do nosso trabalho por terem como objeto também a questão do jornalismo dentro dessa ambiência.

Vasconcelos (2017) analisou a relação do jornalismo com a temporalidade, destacando que a efemeridade é um aspecto latente da prática jornalística desde a sua origem, chegando ao auge com os aplicativos Snapchat e Instagram. Conclusão semelhante também é dada por Assis et al. (2017), que buscou compreender a influência do desenvolvimento tecnológico nas relações entre efemeridade e permanência na produção midiática, em especial, no jornalismo para entender sua relação com as mídias sociais efêmeras.

Barros (2017), em análise sobre a compreensão da construção e do consumo de stories no Snapchat e no Instagram, evidenciou cinco características básicas que permeiam o formato: o caráter cotidiano, a efemeridade, o aspecto imagético, o caráter dialógico e o entretenimento. Adicionalmente, Alves (2018) descreveu as narrativas jornalísticas em formato Stories no Instagram e Snapchat, tendo identificado e caracterizado nove tipos: Narrativa Textual; Textual Hipermidiática; Chamada Hipermidiática; Convite; Convite Hipermidiática; Jornalista Selfie; Nota; Entrevista; e Múltiplos Formatos.

Lemos e Sampaio (2018), a partir de estudo dirigido no Instagram, obtiveram como resultado que, com os Stories,

[...] os usuários estão menos preocupados com a 'aprovação' dos outros, e isso tende a minimizar rigor nos critérios de seleção dos conteúdos publicados. O compartilhamento caracteriza-se por imagens 'mais espontâneas. No Stories, não são momentos especiais para o futuro, mas evento únicos, expressando a dimensão do "aqui e o agora". (LEMOS; SAMPAIO, 2018, p. 24) 
Já Kannemberg e Souza (2017), sobre os Stories do Snapchat, reforçam a característica narrativa e o potencial do uso da plataforma para o jornalismo. "A partir das categorias de análise criadas (periodicidade, tamanho, modalidade narrativa e formato), percebemos similaridades e particularidades nos conteúdos publicados na seção Stories, concluindo que se trata de uma ferramenta com potencial narrativo e de atrair novos públicos" (KANNENBERG; SOUSA, 2017, p. 151).

Com essa revisão, identificamos entre as principais metodologias aplicadas pelos pesquisadores o uso da análise de conteúdo, a partir da sistematização realizada pela pesquisadora Laurence Bardin (2016). Trata-se de um método empírico, composto por um conjunto de instrumentos metodológicos que se aplicam a objetos extremamente diversificados nas ciências humanas. Muito usada em pesquisas na área da comunicação, a análise de conteúdo permite não apenas a descrição, mas também a inferência, estudando as causas e interpretando os efeitos a partir de deduções lógicas.

\subsubsection{O CARÁTER VERSÁTIL DA ANÁLISE DE CONTEÚDO}

A análise de conteúdo, como ferramenta de estudo acadêmico, nasce no começo do século passado nos Estados Unidos e começa a ser usada por outros países com a popularização dessa metodologia após a Segunda Guerra Mundial (BARDIN, 2016). A linha que usaremos nasce no final da década de 1970, a partir da organização de técnicas de análise de conteúdo para as comunicações feita pela professora e pesquisadora da Universidade de Paris V, Laurence Bardin, que assim a define na versão mais atualizada de sua obra:

\footnotetext{
Um conjunto de técnicas de análise das comunicações visando obter por procedimentos sistemáticos e objetivos de descrição de conteúdo das mensagens indicadores (quantitativos ou não) quer permitam a inferência de conhecimentos relativos às condições de produção/recepção (variáveis inferidas) dessas mensagens. (BARDIN, 2016, p. 48)
}

Com abordagem bastante flexível e adaptável, o processo de análise, segundo Bardin (2016), é estruturado por três polos cronológicos: pré-análise, exploração do material e, por último, a análise quantitativa e qualitativa a partir do tratamento dos resultados. 
Ao pesquisarmos sobre a aplicação desse instrumento metodológico, descobrimos que, de acordo com um estudo conduzido por Seramim e Walter (2017), $75 \%$ de artigos que utilizam a análise de conteúdo não deixam claras as etapas definidas por Bardin. Isso se torna, portanto, um problema para os investigadores iniciantes, devido à dificuldade de visualizar a sua aplicação e os passos para a utilização dessa metodologia em trabalhos já publicados.

Em seu livro, a autora faz críticas aos pesquisadores que não compartilham os percalços da pesquisa e colocam apenas "a exposição rigorosa dos resultados finais" (BARDIN, 2016, p. 38). Por isso, para ir na contramão dos investigadores que têm "repugnância em descrever a sua hesitante alquimia" (BARDIN, 2016, p. 38), também decidimos explicar, em algumas notas de rodapé, um pouco das várias rotas do nosso percurso até conseguir formatar um conjunto coerente ${ }^{46}$ de variáveis para a análise apresentada nessa dissertação.

É importante lembrar que, para a pesquisadora, o melhor seria dizer "análises de conteúdo", pois trata-se de um método empírico que pode ser explorado de muitas formas.

Não existe coisa pronta em análise de conteúdo, mas somente regras de base, por vezes, dificilmente transponíveis. A técnica de análise de conteúdo adequada ao domínio e ao objetivo pretendidos tem de ser reinventada a cada momento [...] (BARDIN, 2016, p. 36).

Esse aprofundamento tem como intuito ampliar o acesso a métodos de observação e análise que possam servir de suporte para o estudo de novos formatos de mídia que ganham cada vez mais complexidade em seus modos de funcionamento.

Para Bardin (2016, p 38), "[...] quanto mais o código se torna complexo, ou instável, ou mal explorado, maior terá de ser o esforço do analista, no sentido de uma inovação com vista à elaboração de técnicas novas".

Com isso, identificamos a possibilidade de adaptação de suas técnicas para o estudo dos Stories dentro do ambiente jornalístico. A seguir, apresentaremos as

${ }^{46}$ Consideramos "coerente" dentro do período de duração de um mestrado. É comum que os anos iniciais da vida acadêmica tragam muitas angústias e dúvidas sobre a metodologia a ser seguida. Tivemos que percorrer um bom caminho com o auxílio do nosso orientador até sentir segurança em dose suficiente para aplicar a metodologia ao nosso objeto. Ter nos aprofundado na leitura do livro de Laurence Bardin nos fez pisar menos "em areia movediça". Quanto mais mergulhávamos, mais compreendíamos a formatação que aplicamos aqui. Descobrimos, além disso, que a profundidade desse "mergulho" deve ser sempre proporcional ao tempo disponível para a pesquisa, conscientes de suas limitações para preservar a nossa saúde mental. (:) 
definições de cada etapa proposta por esse conjunto de técnicas e a formatação que fizemos em sua estrutura para compreender a produção de Stories da Folha e do Estadão.

\subsubsection{A ESCOLHA DOS DOCUMENTOS E A CONSTITUIÇÃO DO CORPUS}

Durante a pré-análise, o pesquisador passa pelo "período de intuições" (BARDIN, 2016, p. 125), no qual ele faz a aproximação inicial ao objeto estudado e a composição do corpus da pesquisa. Essa fase é composta por três missões: a escolha dos documentos a serem analisados, a formulação de hipóteses e dos objetivos da pesquisa e, ainda, a formatação dos indicadores que nortearão a interpretação final.

De acordo com Bardin (2016), essas etapas não ocorrem necessariamente em ordem cronológica, apesar de estarem intrinsecamente interligadas. Muitas vezes, elas acabam acontecendo simultaneamente durante a pré-análise e costumam sofrer alterações conforme o avanço do processo.

Antes de explicar as missões colocadas pela autora, cabe esclarecer sobre a estratégia de aproximação ao objeto de pesquisa que ela caracteriza como "leitura flutuante", em analogia à postura de um psicanalista, pois "pouco a pouco, a leitura vai se tornando mais precisa" (BARDIN, 2016, p. 126). É o momento de fazer leituras bibliográficas, verificar teorias que poderão ser utilizadas no decorrer das discussões sobre os materiais, localizar trabalhos que já foram publicados sobre o assunto e pensar em quais documentos serão avaliados.

No período de abordagem inicial, durante o primeiro ano da pesquisa, criamos um perfil no Instagram (@mestradodacarol)47 para seguir exclusivamente empresas jornalísticas do Brasil e de outros países. Acompanhamos os tipos de publicações, os usos e as aplicações das funcionalidades dos Stories e nos familiarizamos com as contas que publicavam com mais frequência e regularidade no Brasil. Esse processo foi importante para a definição da escolha das empresas que seriam acompanhadas na análise.

Posto isso, partimos para a primeira missão da pré-análise, que é a escolha de documentos. De início, é necessário decidir sobre a natureza do documento que será considerado. No nosso caso, são as mídias sociais efêmeras presentes no

\footnotetext{
${ }^{47}$ No Apêndice A é possível ver a lista de todos os perfis jornalísticos seguidos pela conta.
} 
Instagram Stories, pelo fato de se tratar de uma funcionalidade dentro de uma plataforma que, como vimos no capítulo anterior, é mais estável e consolidada no Brasil quando comparada ao Snapchat. Isso fez com que as empresas de jornalismo do país cultivassem um interesse progressivo em seu uso, propiciando para a nossa pesquisa um campo mais vasto de exemplos da atuação jornalística dentro dessa mídia social efêmera.

Depois de decidir sobre o tipo de documento, é necessário constituir o corpus da pesquisa. "O corpus é o conjunto de documentos tidos em conta para serem submetidos aos procedimentos analíticos" (BARDIN, 2016, p. 126). Essa escolha deve ser pautada seguindo algumas regras, sendo as principais:

\footnotetext{
Regra da exaustividade: uma vez definido o campo do corpus [...], é preciso ter em conta todos os elementos desse corpus. Em outras palavras, não se pode deixar de fora qualquer um dos elementos por esta ou aquela razão [...] que não possa ser justificável no plano do rigor. Esta regra é completada pela de não seletividade.

$[\ldots]$

Regra da representatividade: $\mathrm{A}$ análise pode efetuar-se numa amostra desse material que a isso se preste. A amostragem diz-se rigorosa se a amostra for uma parte representativa do universo inicial. Neste caso, os resultados obtidos para a mostra serão generalizados ao todo.

[...]

Regra da homogeneidade: os documentos retidos devem ser homogêneos, isto é, devem obedecer a critérios precisos de escolha e não apresentar demasiada singularidade fora desses critérios.

$[\ldots]$

Regra da pertinência: os documentos retidos devem ser adequados enquanto fonte de informação, de modo a corresponderem ao objetivo que suscita a análise. (BARDIN, 2016, p. 126-128, grifos da autora)
}

Tendo em mente a regra de exaustividade, decidimos que coletaríamos todos os stories publicados durante o período de análise, considerando inclusive eventuais intervenções publicitárias, por entendermos que essa presença também faz parte da atividade de uma empresa de jornalismo e também nos oferece dados importantes para contextualizar o momento atual da comunicação.

Seguindo a regra da representatividade, escolhemos o período de sete dias para representar o universo amostral da pesquisa. Registramos as publicações de uma semana sem eventos midiáticos previstos de grandes proporções, como a transmissão do Carnaval ou de eventos esportivos, com o objetivo de apresentar uma 
maior diversidade de coberturas jornalísticas e com a possibilidade de observar as temáticas que são mais comuns nos stories ${ }^{48}$ dessas empresas.

Para respeitar a regra da homogeneidade, escolhemos duas empresas jornalísticas com abrangência nacional e um histórico de atuação próximos: Estadão e Folha de S. Paulo. Consolidadas no mercado de notícias, as duas empresas apresentaram regularidade de postagens em seus perfis no Instagram durante a nossa observação preliminar dentro da plataforma, o que nos deu maior segurança quanto à disponibilidade de stories, já que a probabilidade de ambas terem postagens em todos os sete dias da semana ${ }^{49}$ seria maior.

A última citada, a regra de pertinência, diz respeito à compatibilidade da amostra ao objetivo da análise. O recorte que fizemos, apesar de não ser muito amplo, serve ao propósito de fornecer uma visão do uso das funcionalidades e das características da atuação jornalística nas mídias sociais efêmeras.

A análise empírica complementa a nossa pesquisa bibliográfica de contextualização, fornecendo indicadores para a reflexão sobre o cenário atual do ecossistema de comunicação.

A coleta ocorreu entre os dias 25 de maio (uma segunda-feira) e 31 de maio (um domingo) de 2020. Uma vez por dia, durante esse período, coletamos todos os stories publicados pelos perfis do Estadão e da Folha de S. Paulo, por meio da

\footnotetext{
${ }^{48}$ Antes do exame de qualificação, fizemos um teste de coleta reunindo as publicações de cinco canais esportivos de televisão no Instagram Stories durante a Copa do Mundo de 2018. A intenção era estabelecer uma ligação entre o formato televisivo e os Stories. Esbarramos nos seguintes problemas: grande volume de dados para sistematização e foco direcionado exclusivamente ao futebol. Em vez de encontrarmos um aprofundamento e diversidade de ferramentas no uso da plataforma, observamos a repetição no uso de recursos durante os dias, seguindo a grade de cobertura do evento. Decidimos, após essa experiência, mudar o nosso recorte para veículos que fazem cobertura nacional e internacional de notícias e a diminuição do período de representatividade de um mês para uma semana a fim de possibilitar um melhor arranjo do corpus. No entanto, com a aproximação da fase de coleta no nosso cronograma, a cobertura da mídia passou a ser quase exclusivamente sobre o avanço da COVID-19. Aceitamos que essa realidade faz parte dos dados, tendo em vista a singularidade do momento que a humanidade vive durante a escrita dessa dissertação.
}

49 O cenário da pandemia também modificou a composição do nosso corpus. Nas etapas preliminares do projeto de pesquisa, o jornal $O$ Globo também integrava a lista de empresas selecionadas para o acompanhamento dentro do Instagram. Mas, durante o período de coleta, nenhum story foi criado pela empresa, que passou a utilizar apenas o espaço permanente da plataforma (feed) para publicação de imagens. Questionamos o jornal por mensagem direta no Instagram, mas não obtivemos esclarecimento sobre os motivos para essa abstenção do uso dos Stories. Existe a possibilidade de a mudança ter ocorrido em função da redistribuição de trabalho que todas as redações precisaram fazer em suas estruturas de colaboradores, já que muitas atividades passaram por modificações com a maioria dos jornalistas trabalhando dentro de suas casas. 
gravação de tela disponível nativamente no iPad, dispositivo móvel que utiliza o sistema operacional da empresa de tecnologia Apple.

Com a captura da tela do iPad, tal como exemplificado nas figuras 1 e 2 a seguir, gravamos a navegação pelos stories, observando e clicando em todas as funcionalidades aplicadas pelas empresas, no esforço de registrar o máximo de interação possível.

Figura 1.16 - Exemplo de captura de tela do iPad com reprodução de story do Estadão.

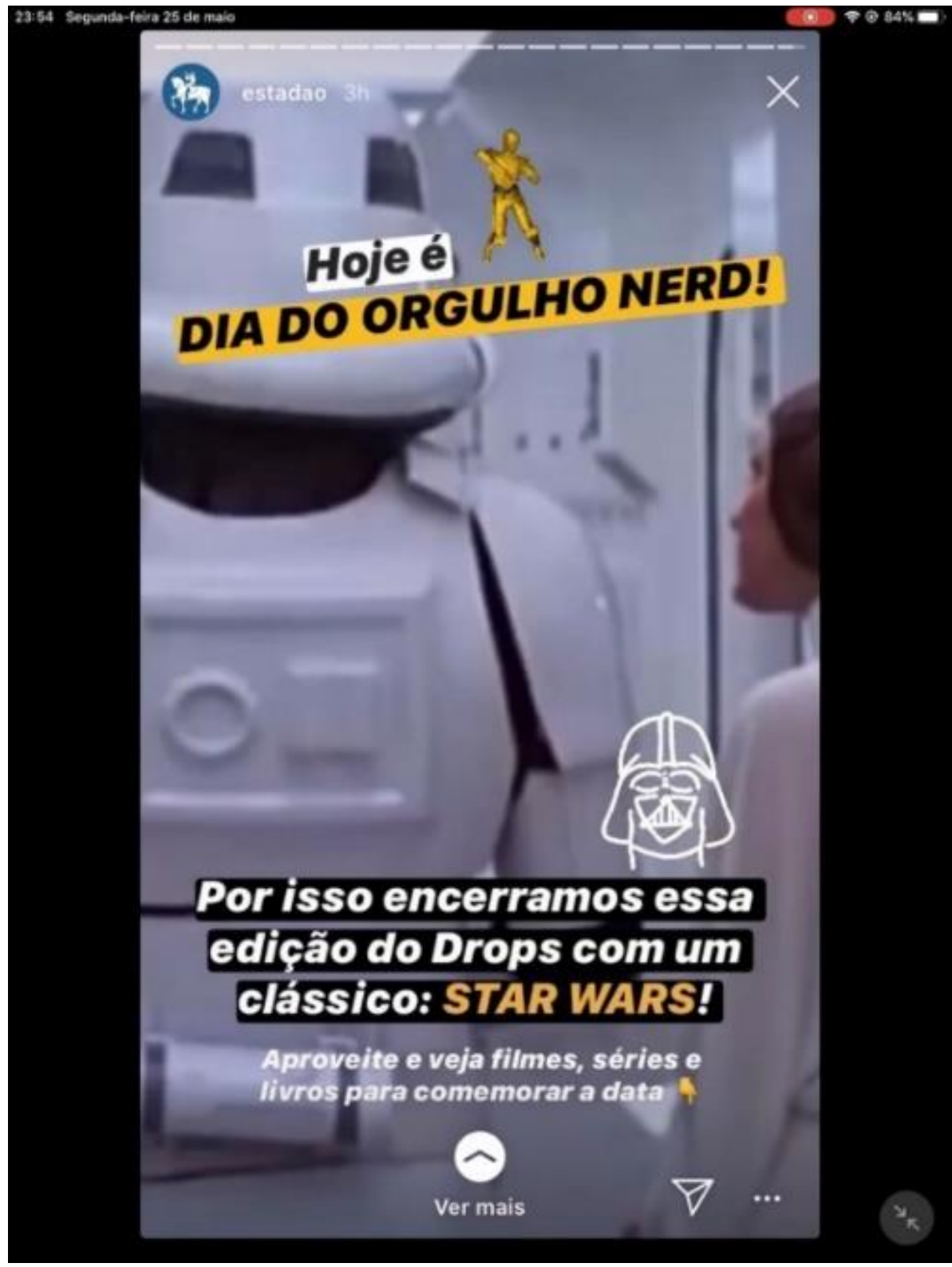

Fonte: a autora (2020). 
Figura 1.17 - Exemplo de captura de tela do iPad com reprodução de story da Folha de S. Paulo.

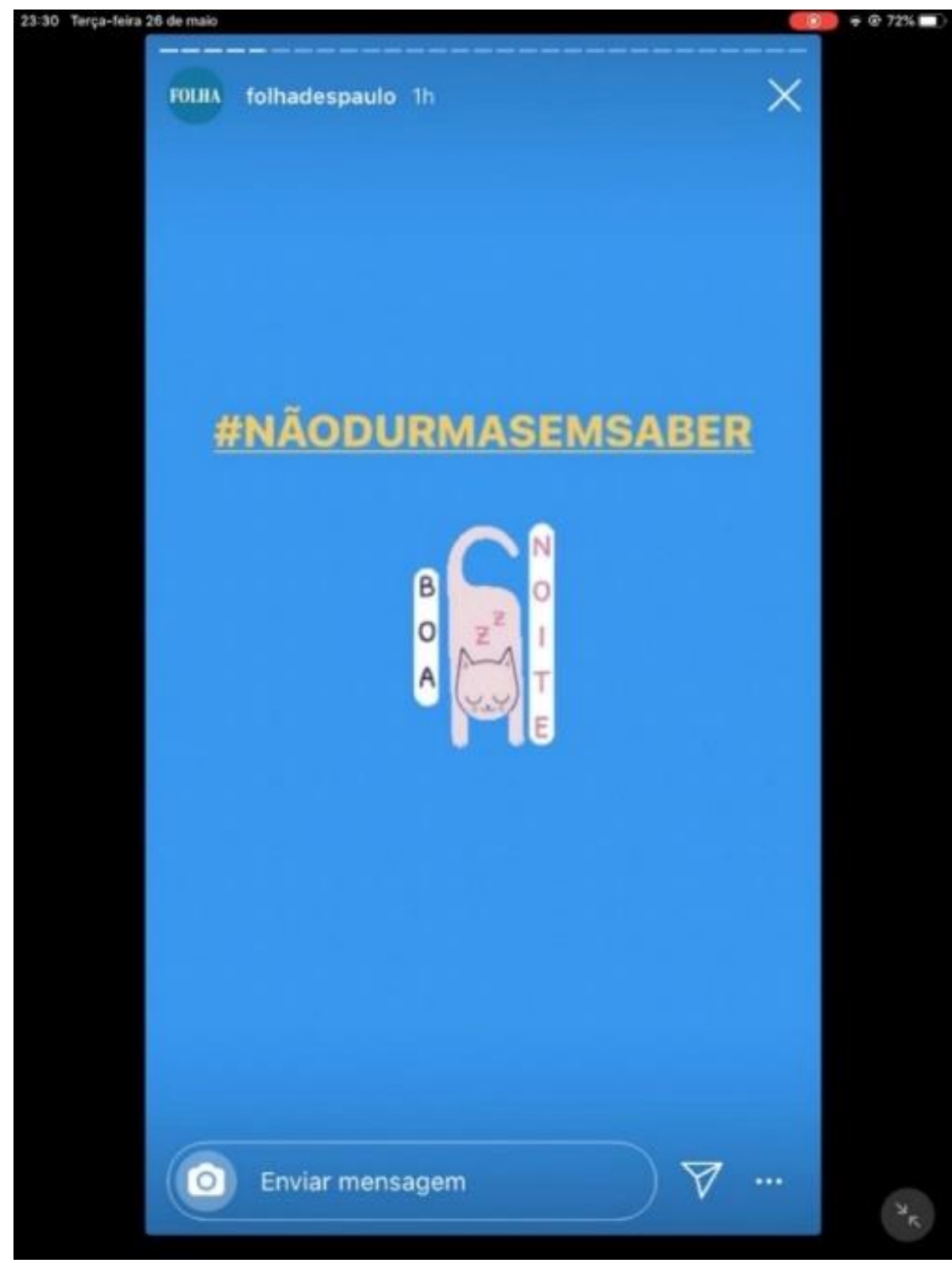

Fonte: a autora (2020).

\subsubsection{A FORMULAÇÃO DAS HIPÓTESES E DOS OBJETIVOS}

Nem todas as análises de conteúdo partem de hipóteses definidas, segundo Bardin (2016). Entretanto, na nossa pesquisa, a elaboração de interrogações iniciais foi tão importante quanto a escolha dos documentos para o direcionamento da análise. Bardin (2016, p. 128) define hipótese como sendo "uma afirmação provisória que nos propomos a verificar (confirmar ou infirmar), recorrendo a procedimentos de análise". 
Essas suposições surgem, muitas vezes, a partir da intuição do pesquisador depois de percorrer o assunto no período de leitura flutuante.

Abaixo, apresentamos as principais hipóteses ${ }^{50}$ que nortearam a escolha dos itens analisados na observação das amostras coletadas e, em seguida, os objetivos da análise:

a) a maioria dos stories são usados apenas como "iscas" para levar a audiência ao site da marca por meio de links integrados à imagem;

b) pela plataforma usar o celular na vertical e privilegiar a imagem no formato retrato, a presença humana existe na maioria dos stories;

c) a informação que é passada nos stories reproduz de forma muito semelhante ou igual o conteúdo do título e do subtítulo das matérias jornalísticas para onde os links levam;

d) os assuntos tratados variam conforme o dia da semana;

e) algumas editorias são mais privilegiadas do que outras na frequência de aparição nos stories;

f) fica claro para a audiência quando o jornal usa publicidade dentro dos stories;

g) mesmo em um contexto de grande circulação de fotos, de memes e de reproduções de vídeos, o jornalismo dá crédito para os autores ou indica a origem das imagens;

h) as empresas concentram a publicação dos stories em um horário específico;

i) as possibilidades de interação com a audiência nos stories são pouco exploradas pelos jornais.

Quanto aos objetivos dessa parte empírica da pesquisa, temos como principal meta descrever a produção de stories com o propósito de apresentar práticas usuais encontradas em perfis de jornais brasileiros dentro do Instagram Stories. A partir da exploração das amostras coletadas, também temos como objetivo interpretar os resultados da análise por meio de uma contextualização teórica, abrindo espaço para discutir os valores existentes no ecossistema dos Stories.

50 Possíveis respostas para as hipóteses aqui presentes foram formuladas após a análise e estão disponíveis no item 2.3.1 desse capítulo. 


\title{
1.3.5 OS CRITÉRIOS LOGÍSTICOS E OPERACIONAIS DA ANÁLISE
}

Também faz parte da pré-análise a escolha do recorte da amostra e a divisão dos dados originários da observação em itens, que Bardin (2016) denomina unidades de registro. Essas unidades são reunidas segundo suas similaridades ou necessidades específicas da análise em grupos maiores, as unidades de contexto. A partir dessa codificação, é possível desenvolver indicadores que detalham aspectos essenciais do objeto, capacitando o analista a classificar e a organizar os elementos da pesquisa em categorias. Bardin (2016) assim exemplifica o processo:

\begin{abstract}
A técnica consiste em classificar os diferentes elementos nas diversas gavetas segundo critérios suscetíveis de fazer surgir um sentido capaz de introduzir alguma ordem na confusão inicial. É evidente que tudo depende, no momento da escola dos critérios de classificação, daquilo que se procura ou que se espera encontrar. (BARDIN, 2016, p. 43, grifo da autora)
\end{abstract}

Utilizamos quatro operações para construir a nossa pré-análise: a identificação das unidades de registro (a), o agrupamento dos itens em unidades de contexto (b), a escolha dos critérios de contagem para as análises estatísticas (c) e a (d) preparação do material para o momento de exploração:

a) Unidades de registro

No quadro 1.1 (a seguir), apresentamos as quarenta unidades de registro ${ }^{51}$ que são utilizadas para a nossa análise. Para chegar a esse número, fizemos um préteste com uma parte da amostra - dois dias de coleta dos stories de cada jornal - para descobrir se o conjunto possuía coerência interna ${ }^{52}$ e para nos assegurar que seria possível responder às hipóteses da pesquisa.

A lista foi numerada e codificada a partir da aplicação do teste prévio, momento em que observamos a ordem que mais facilitaria o preenchimento de planilhas do Excel, programa de gerenciamento de dados que decidimos utilizar por

\footnotetext{
51 A aplicação das unidades de registro e suas conceituações serão detalhadas a partir do próximo item, na seção "b) Unidades de contexto".

52 Anteriormente, a lista era composta por 72 itens. No entanto, durante a avaliação, percebeu-se que algumas unidades se mostraram redundantes ou não relevantes para o nosso estudo. Outras também foram incluídas a partir de observações do conteúdo da coleta, como, por exemplo, a unidade F/E-40, que mapeia a presença ou ausência de palavras associadas a notícias urgentes no texto do story.
} 
ter a capacidade de armazenar informações e de processá-las estatisticamente por meio de fórmulas relativamente simples. O objetivo da codificação é facilitar a localização das informações durante o período de operações matemáticas.

\section{Quadro 1.1 - Unidades de registro construídas para o universo dos Stories}

\begin{tabular}{|l|l|l|l|}
\hline \multicolumn{4}{|c|}{ Unidades de registro para a Folha de S. Paulo (F) e para o Estadão (E) } \\
\hline $\begin{array}{l}\text { F/E-01 Breve descrição } \\
\text { da imagem }\end{array}$ & $\begin{array}{l}\text { F/E-11 Branded } \\
\text { content }\end{array}$ & $\begin{array}{l}\text { F/E-21 Etiqueta de } \\
\text { Localização }\end{array}$ & $\begin{array}{l}\text { F/E -31 Link para o site } \\
\text { sem paywall }\end{array}$ \\
\hline $\begin{array}{l}\text { F/E-02 Layout } \\
\text { personalizado com } \\
\text { design pré-produzido }\end{array}$ & $\begin{array}{l}\text { F/E -12 Conteúdo } \\
\text { editorial-noticioso }\end{array}$ & $\begin{array}{l}\text { F/E-22 Etiqueta de } \\
\text { Hashtag }\end{array}$ & $\begin{array}{l}\text { F/E-32 Link para outro } \\
\text { aplicativo }\end{array}$ \\
\hline $\begin{array}{l}\text { F/E-03 Layout } \\
\text { semelhante ao nativo do } \\
\text { Instagram }\end{array}$ & $\begin{array}{l}\text { F/E-13 Temática } \\
\text { central }\end{array}$ & $\begin{array}{l}\text { F/E-23 Etiqueta de } \\
\text { Música }\end{array}$ & $\begin{array}{l}\text { F/E-33 Link para } \\
\text { conteúdo publicitário }\end{array}$ \\
\hline $\begin{array}{l}\text { F/E-04 Imagem vertical } \\
\text { (full screen) }\end{array}$ & $\begin{array}{l}\text { F/E -14 Créditos de } \\
\text { imagens/textos }\end{array}$ & $\begin{array}{l}\text { F/E-24 Presença de } \\
\text { texto }\end{array}$ & $\begin{array}{l}\text { F/E-34 Link para } \\
\text { branded content }\end{array}$ \\
\hline $\begin{array}{l}\text { F/E-05 Imagem } \\
\text { predominantemente } \\
\text { horizontal }\end{array}$ & $\begin{array}{l}\text { F/E-15 Crédito de } \\
\text { produção dos stories }\end{array}$ & $\begin{array}{l}\text { F/E-25 Quantidade de } \\
\text { palavras }\end{array}$ & F/E-35 Repost \\
\hline $\begin{array}{l}\text { F/E-06 Imagem com } \\
\text { filtro }\end{array}$ & $\begin{array}{l}\text { F/E-16 Jornalista } \\
\text { selfie }\end{array}$ & $\begin{array}{l}\text { F/E-26 Texto } \\
\text { semelhante ao site }\end{array}$ & $\begin{array}{l}\text { F/E-36 Etiqueta de } \\
\text { pergunta }\end{array}$ \\
\hline $\begin{array}{l}\text { F/E-07 Imagem estática } \\
\text { F/E-17 Imagem de } \\
\text { origem jornalística }\end{array}$ & F/E-27 Palavras-chave & $\begin{array}{l}\text { F/E-37 Etiqueta de } \\
\text { menção }\end{array}$ \\
\hline $\begin{array}{l}\text { F/E-10 Conteúdo } \\
\text { publicitário } \\
\text { movimento Imagem com }\end{array}$ & $\begin{array}{l}\text { F/E-18 Imagem de } \\
\text { terceiros reproduzida }\end{array}$ & $\begin{array}{l}\text { F/E-28 Presença de } \\
\text { áudio }\end{array}$ & $\begin{array}{l}\text { F/E-38 Permite } \\
\text { mensagens diretas (DM) }\end{array}$ \\
\hline $\begin{array}{l}\text { F/E-09 Presença } \\
\text { humana na imagem }\end{array}$ & $\begin{array}{l}\text { F/E-19 Não é possível } \\
\text { identificar origem da } \\
\text { imagem (uso intenso } \\
\text { de filtro) }\end{array}$ & F/E-29 Link & $\begin{array}{l}\text { F/E-39 Período do dia } \\
\text { em que foi publicado }\end{array}$ \\
\hline forivo (gif ou & $\begin{array}{l}\text { F/E-30 Link para o site } \\
\text { com paywall }\end{array}$ & $\begin{array}{l}\text { F/E-40 Características } \\
\text { de breaking news }\end{array}$ \\
\hline
\end{tabular}

Fonte: elaborado pela autora (2020).

$\mathrm{O}$ "F" no início do código indica que os dados são referentes à amostra da Folha de S. Paulo. Para o Estadão, usamos a letra "E" em suas unidades de registro. Os códigos também auxiliam a organização da apresentação dos resultados do estudo por meio de gráficos e de outras modalidades de visualização de dados, que serão apresentados no item 2.4 deste capítulo. 
b) Unidades de contexto

A unidade de contexto ajuda a compreensão da unidade de registro, pois serve como uma caixa na qual podemos alocar os itens que têm relação direta entre si. Bardin (2016) explica as unidades de contexto usando como analogia a frase (unidade de contexto) para a palavra (unidade de registro), ou seja, dentro de uma frase podem existir várias classes de palavras: substantivo, verbo, adjetivo etc.

Nessa etapa, depois de listar todas as unidades de registro usando como ponto de partida a leitura flutuante e a formulação de hipóteses, partimos para a separação dos itens que pertenciam a tópicos similares. Percebemos que a distribuição poderia ser facilitada com o uso de algumas perguntas para guiar o processo, como, por exemplo: "quando o story foi ao ar?"; "o que é mostrado no story?". Para a criação dessas questões nos inspiramos nas perguntas que orientam a escrita dos parágrafos iniciais das notícias no jornalismo, espaço conhecido como lide, e que fornecem de forma rápida as principais informações do texto ao leitor: o quê (a ação), quem (o agente), quando (o tempo), onde (o lugar), como (o modo) e por que (o motivo) (PENA, 2012).

É importante apontar que, a depender do objetivo da análise conduzida, algumas unidades de registro podem variar quanto à escolha da unidade de contexto.

Durante a pré-análise, optamos pela distribuição das quarenta unidades de registro nas respectivas unidades de contexto, criadas durante a pré-análise e apresentadas a seguir: temporalidade, temática, referência, formato, finalidade, interatividade e hiperlink.

- Temporalidade (quadro 1.2): os indicadores temporais nos permitem aferir quais são os horários com maior frequência de publicação dos stories e verificar se existe uma relação direta entre algum tipo de conteúdo e o horário em que eles foram postados:

Quadro 1.2 - Unidades de temporalidade

\begin{tabular}{|c|}
\hline Quando o story foi ao ar? \\
\hline F/E-39 Período do dia em que foi publicado \\
\hline F/E-40 Características de breaking news \\
\hline
\end{tabular}

Fonte: elaborado pela autora (2020). 
- Temática (quadro 1.3): os indicadores temáticos possibilitam a descrição dos itens relacionados ao assunto tratado no story. A partir desses dados, é possível, por exemplo, entender os assuntos mais presentes nos stories ou os tópicos nos quais os tipos de adesivos aparecem com mais frequência:

\section{Quadro 1.3 - Unidades de temática}

\begin{tabular}{|l|}
\hline \multicolumn{1}{|c|}{ O que é mostrado no story? } \\
\hline F/E-01 Breve descrição da imagem \\
\hline F/E-09 Presença humana na imagem \\
\hline F/E-13 Temática central \\
\hline F/E-20 Adesivo (gif ou emoji) \\
\hline F/E-27 Palavras-chave \\
\hline
\end{tabular}

Fonte: elaborado pela autora (2020).

- Referência (quadro 1.4): os indicadores de referência nos dão pistas sobre a origem dos itens presentes no story. Entre outras informações, buscamos entender se a chamada de texto foi extraída diretamente do título da matéria ou do subtítulo para onde o link do story nos leva e se as imagens que os jornais usam são, em sua maioria, produzidas internamente ou reproduzidas a partir de fontes externas:

\section{Quadro 1.4 - Unidades de referência}

\begin{tabular}{|l|}
\multicolumn{1}{|c|}{ De onde vem o conteúdo do story? } \\
\hline F/E-02 Layout personalizado com design pré-produzido \\
\hline F/E-03 Layout semelhante ao nativo do Instagram \\
\hline F/E-14 Créditos de imagens/textos \\
\hline F/E-15 Crédito de produção dos stories \\
\hline F/E-17 Imagem de origem jornalística \\
\hline F/E-18 Imagem de terceiros reproduzida \\
\hline F/E-19 Não é possível identificar origem da imagem (uso intenso de filtro) \\
\hline F/E-26 Texto semelhante ao site \\
\hline
\end{tabular}

Fonte: elaborado pela autora (2020) 
- Formato (quadro 1.5): os indicadores de formato nos dão informações sobre o aspecto audiovisual dos stories e sobre a configuração das imagens utilizadas para estruturar e dar forma ao seu conteúdo:

Quadro 1.5 - Unidades de formato

\begin{tabular}{|l|}
\hline \multicolumn{1}{|c|}{ Como é configurado o story? } \\
\hline F/E-04 Imagem vertical (full screen) \\
\hline F/E-05 Imagem predominantemente horizontal \\
\hline F/E-06 Imagem com filtro \\
\hline F/E-07 Imagem estática \\
\hline F/E-08 Imagem com movimento \\
\hline F/E-16 Jornalista selfie \\
\hline F/E-24 Presença de texto \\
\hline F/E-25 Quantidade de palavras \\
\hline F/E-28 Presença de áudio \\
\hline
\end{tabular}

Fonte: elaborado pela autora (2020).

- Finalidade (quadro 1.6): os indicadores de finalidade apontam o propósito do story: publicitário, jornalístico ou para a promoção de conteúdo editorial feito a partir de demandas de marcas, o chamado branded content, cujos benefícios "estão na sua capacidade de não ser reconhecido pelo público como conteúdo patrocinado" (RIBEIRO JR., 2019, p. 367):

Quadro 1.6 - Unidades de finalidade

Por que o story foi feito?

F/E-10 Conteúdo publicitário

F/E-11 Branded content

F/E-12 Conteúdo editorial-noticioso

Fonte: elaborado pela autora (2020). 
- Interatividade (quadro 1.7): os indicadores de interatividade mostram se existe uma relação dialógica entre as partes, como em uma conversa. A intenção é verificar se existem elementos que convidam a participação do usuário, seja por meio de enquetes, seja por meio do uso de hashtags ou de outras funcionalidades disponíveis dentro da interface do Instagram Stories:

Quadro 1.7 - Unidades de interatividade

\begin{tabular}{|l|}
\hline \multicolumn{1}{|c|}{ Quem conversa no story? } \\
\hline F/E-21 Etiqueta de Localização \\
\hline F/E-22 Etiqueta de Hashtag \\
\hline F/E-23 Etiqueta de Música \\
\hline F/E-36 Etiqueta de pergunta \\
\hline F/E-38 Permite mensagens diretas (DM) \\
\hline
\end{tabular}

Fonte: elaborado pela autora (2020).

- Hiperlink (quadro 1.8): nos indicadores de hiperlink, além dos links que direcionam para ambientes externos, como sites e outros aplicativos, também adicionamos a essa unidade de contexto o uso de menções a outros perfis do Instagram e o uso da funcionalidade de repost dentro de um story, seja de outros stories externos, seja de publicações de feed, já que todos esses elementos têm por objetivo indicar um caminho alternativo para o usuário, diferente do fluxo natural da sequência de stories postada pelos jornais:

Quadro 1.8 - Unidades de hiperlink

\begin{tabular}{|l|}
\hline \multicolumn{1}{|c|}{ Para onde o story direciona? } \\
\hline F/E-29 Link \\
\hline F/E-30 Link para o site com paywall \\
\hline F/E-31 Link para o site sem paywall \\
\hline F/E-32 Link para outro aplicativo \\
\hline F/E-33 Link para conteúdo publicitário \\
\hline F/E-34 Link para branded content \\
\hline F/E-35 Repost \\
\hline F/E-37 Etiqueta de menção \\
\hline
\end{tabular}

Fonte: elaborado pela autora (2020). 
Os dados recolhidos em cada uma das unidades de contexto servirão para compor indicadores dentro do campo a que se destinam. Dentro da planilha do programa Excel, a partir da elaboração de operações estatísticas elementares, poderemos visualizar relações entre os dados e obter as possíveis respostas para as nossas hipóteses.

c) A matemática por trás dos dados

A identificação dos critérios utilizados para a análise quantitativa e qualitativa faz parte da etapa de pré-análise. Bardin (2016) recomenda estabelecer as regras de enumeração da pesquisa, ou seja, o modo como as unidades serão contadas. É a fase de desenvolver parâmetros estatísticos para descobrir o que os dados brutos podem revelar sobre o conteúdo da amostra.

Entre as opções disponíveis para a análise de conteúdo, a frequência geralmente é a mais usada, com a indicação da aparição dos elementos monitorados. Utilizamos esse modo de contagem para 35 unidades de registro. Deixamos de fora o indicador que mostra a quantidade de palavras em cada story (F/E-25) e os indicadores das unidades temáticas referentes à descrição da imagem (F/E-01), ao assunto central (F/E-13) e às palavras-chave (F/E-027). Nesses casos, aplicamos análises qualitativas, observando a especificidade de cada um.

\footnotetext{
A abordagem quantitativa funda-se na frequência de aparição de determinados elementos da mensagem. A abordagem não quantitativa recorre a indicadores não frequenciais suscetíveis de permitir inferências; por exemplo, a presença (ou a ausência) pode constituir um índice tanto (ou mais) frutífero que a frequência de aparição. (BARDIN, 2016, p.144)
}

Além desses, outros critérios de contagem úteis para a exploração do nosso material são a "ordem", que permite verificar se existe alguma preferência de distribuição na apresentação dos assuntos publicados diariamente pelos jornais, e a "coocorrência", que monitora os itens presentes simultaneamente dentro de um mesmo story. 
d) A conclusão da etapa preliminar

Por fim, a etapa de pré-análise se encerra com a preparação das amostras e dos instrumentos de interpretação que servirão de suporte para o próximo polo cronológico da análise, a "exploração do material” (BARDIN, 2016).

Após salvar os vídeos da captura de tela no armazenamento local do iPad, também subimos os arquivos em um serviço de armazenamento online. Posteriormente, os stories das duas empresas foram organizados em pastas separadas para facilitar a visualização e a sistematização dos dados.

Da mesma forma, as planilhas de Exce/ utilizadas para o registro das unidades na etapa de observação das amostras foram editadas com a opção de salvamento automático ativada, um serviço disponível no Office 365, da empresa Microsoft, que sincroniza os dados com uma cópia online. Apesar de esses processos de backup parecerem banais, entendemos que a fragilidade e a instabilidade dos arquivos digitais pedem uma cautela maior do pesquisador.

Com isso, na sequência mergulharemos no universo dos Stories do Estadão e da Folha. A partir de um panorama na história dos dois jornais, contextualizaremos a descrição e a classificação das amostras coletadas de cada um de seus perfis no Instagram. 


\section{OS STORIES DO ESTADÃO E DA FOLHA NO INSTAGRAM}

A Folha de S. Paulo e o Estadão são jornais com experiência consolidada no ramo jornalístico. A Folha completará 100 anos em 2021 e o Estadão já conta com 145 anos de história. Viram a ascensão do rádio, da televisão, da computação pessoal e da Internet, coexistindo com todas essas mídias e precisando se adaptar e inovar e para manter o interesse do público e a relevância no meio jornalismo. A chegada das mídias sociais efêmeras, assim como a das demais mídias citadas, trouxe também para os dois jornais um novo desafio: adequar o conteúdo jornalístico à essa mídia para captar a atenção do público que consome Stories.

De forma experimental, ambos passaram a usar o Instagram Stories após o seu lançamento, em agosto de 2016. A regularidade nas postagens passou a existir a partir do ano seguinte. O Estadão lançou, em julho de 2017, o "Estadão Drops", uma coleção de stories com os destaques do noticiário do dia e os bastidores da redação do jornal (ESTADÃO, 2017). No caso da Folha de S. Paulo, a rotina de stories começou em março de 2018 com o "Não Durma Sem Saber", um resumo das notícias mais importantes do dia, publicado à noite (CAMILLO, 2019).

Para entender a atuação dessas duas empresas jornalísticas dentro do Instagram Stories faremos, a seguir, um breve resumo da trajetória de cada uma delas, destacados os principais eventos de suas histórias a fim de oferecer contexto às observações e análises que serão realizadas nesse capítulo. 


\subsection{BREVE HISTÓRIA DOS JORNAIS: DO IMPRESSO AOS STORIES}

O Grupo OESP (Estado) e o Grupo Folha são dois dos maiores conglomerados de mídia do país e ocupam lugares de destaque na indústria das comunicações do Brasil. A seguir, destacamos alguns pontos importantes a respeito de seus empreendimentos.

\subsubsection{ESTADÃO}

Um dos primeiros jornais impressos a circular no Brasil, o Estadão nasce em 1875 com o nome de "A Província de São Paulo". Após a Proclamação da República, passa a se chamar "O Estado de S. Paulo".

Após mais de um século de vida no mercado impresso, a atuação no digital se intensifica em 2000, quando o portal estadao.com.br passou a reunir todo o conteúdo produzido pelo Grupo Estado - os jornais O Estado de S. Paulo e Jornal da Tarde, Agência Estado, Rádio Eldorado e Listas Oesp Estadão (figura 2.1) (MEDIA OWNERSHIP MONITOR BRASIL, 2017).

Figura 2.1 - Levantamento da MOM-Brasil que mostra as principais empresas do Grupo Estado

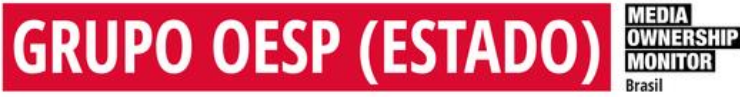

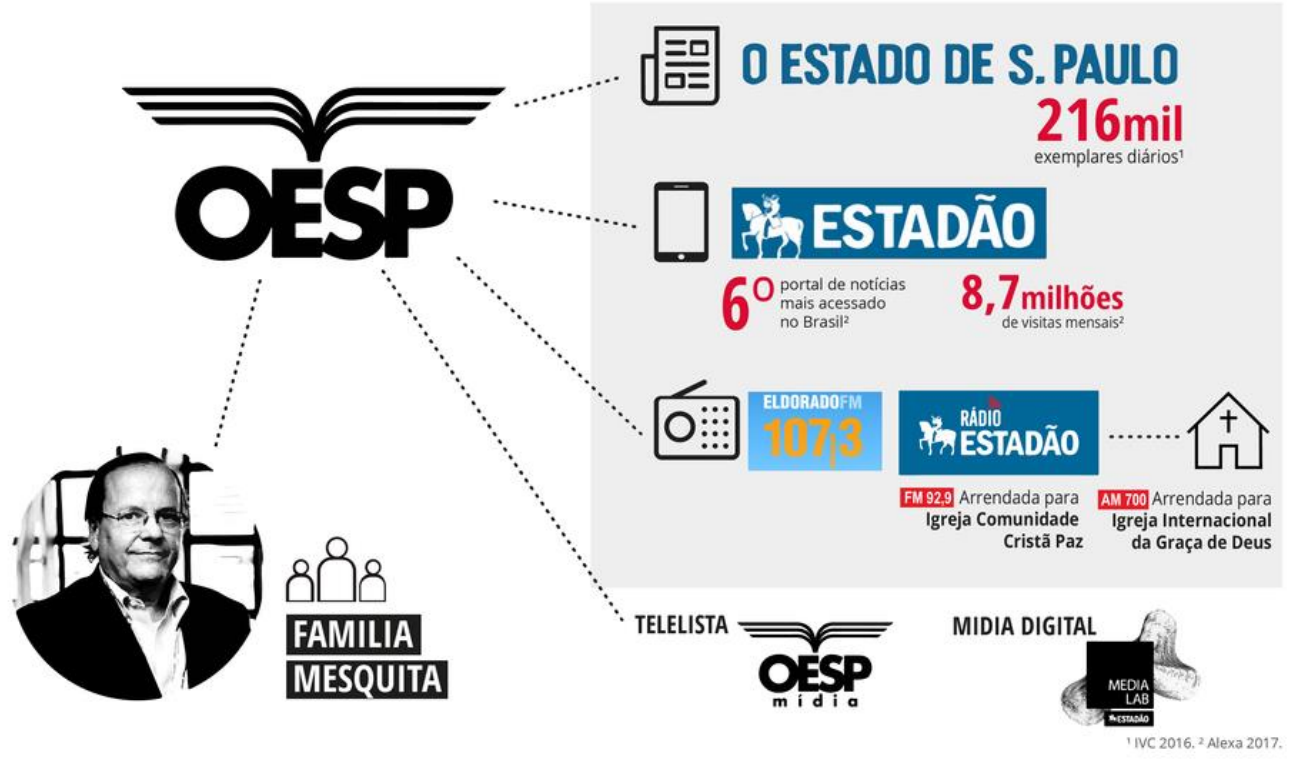


A partir de 2009 a edição digital do jornal passou a estar também nos dispositivos móveis, quando o Estadão lançou um aplicativo para o iPad. A versão para Android viria em 2011. Em 2014, o portal adotou o sistema de assinatura digital, com o uso de paywall e limite de visualizações gratuitas mensais.

Em 2017, o Grupo Estado lançou o Media Lab Estadão, divisão que reúne projetos especiais na área de publicidade e que oferece serviços para empresas como branded content (conteúdo de marcas), organização e divulgação de eventos, gerenciamento de redes sociais, mídia impressa, digital e rádio.

Nas mídias sociais, o Estadão está presente em diversas plataformas, como Facebook, YouTube e Instagram. A última rede social a ser adotada para produção e distribuição de conteúdo foi o TikTok, no final de 2019.

\subsubsection{FOLHA}

A história do jornal começa em 1921, mas é apenas em 1960 que o empreendimento passa a se chamar Folha de S. Paulo.

Com presença na Internet desde 1995, em 2010 as redações do jornal impresso e online são unificadas. O projeto gráfico revitaliza o jornal e seu site passa a se chamar Folha.com. Também em 2010 são lançados aplicativos para iPhone, iPad e Galaxy Tab.

Em 2012 a Folha se torna o primeiro veículo do Brasil a adotar o paywall poroso, um modelo de negócio para jornalismo digital que despontava no exterior no qual o acesso ao noticiário online é gratuito até certo limite de textos.

Presente em quase todas as mídias sociais mais populares da Internet, em fevereiro de 2018, o Grupo Folha (figura 2.1) deixou de usar o Facebook para distribuir notícias em protesto às mudanças do algoritmos da plataforma, que passariam a privilegiar postagens de amigos e de familiares em detrimento do conteúdo de páginas de empresas, incluindo as de jornalismo profissional. No entanto, a Folha permanece no Instagram, uma empresa que faz parte do Grupo Facebook, onde o jornal conta com mais de 2,4 milhões de seguidores. 


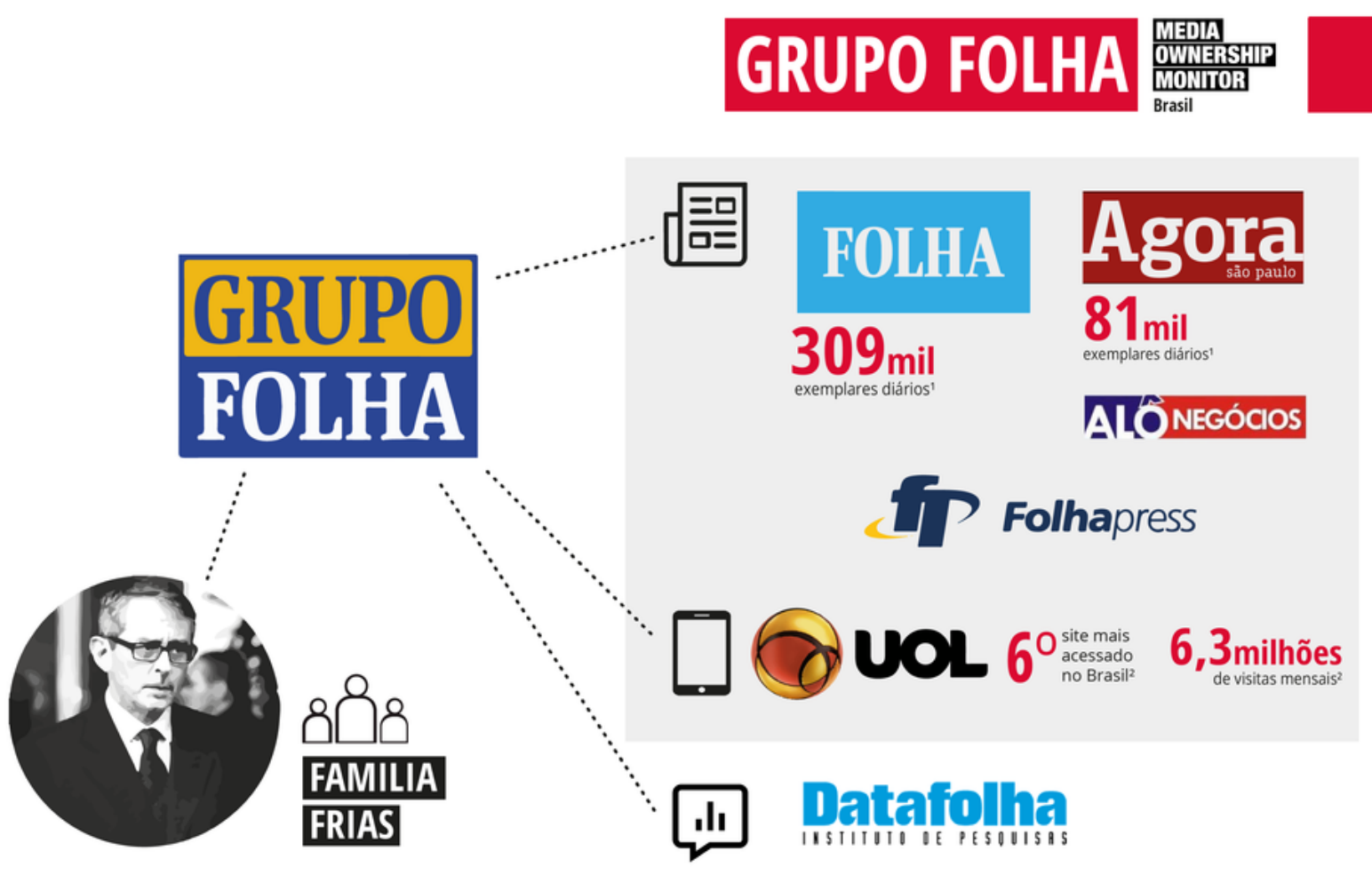

Fonte: MEDIA OWNERSHIP MONITOR BRASIL, 2017.

A seguir, veremos o detalhamento quantitativo das amostras de stories coletadas nos perfis das empresas jornalísticas selecionadas. 


\subsection{DE OLHO NOS DADOS: AS POSTAGENS NOS STORIES DOS JORNAIS}

Nesta seção, listamos observações e análises numéricas dos stories que foram ao ar nos perfis do Instagram do Estadão e da Folha, na semana de 25 a 31 de maio de 2020. Cada uma das postagens foi coletada e organizada conforme sistematização metodológica apresentada no primeiro capítulo.

A seguir, descrevemos as principais observações a respeito das amostras recolhidas. No item 2.4, faremos a interpretação dos dados sob o ponto de vista do aproveitamento dos recursos da plataforma pelas empresas, destacando os pontos mais relevantes para as hipóteses levantadas no começo da análise.

\subsubsection{ESTADÃO}

Durante a semana analisada, a conta oficial do Estadão no Instagram publicou 126 stories. O período do dia com mais postagens foi o da tarde, das $12 \mathrm{~h}$ às $18 \mathrm{~h}$, com $57,1 \%$ do total. À noite, após as $18 \mathrm{~h}$, foram publicados $41,3 \%$. A exceção ficou para $1,6 \%$ dos stories, no sábado, quando duas publicações foram ao ar de manhã. $A$ distribuição semanal de stories no perfil do Estadão mostra uma queda significativa de postagens no fim de semana (figura 2.3).

Figura 2.3 -Distribuição semanal dos stories no perfil do Estadão no Instagram

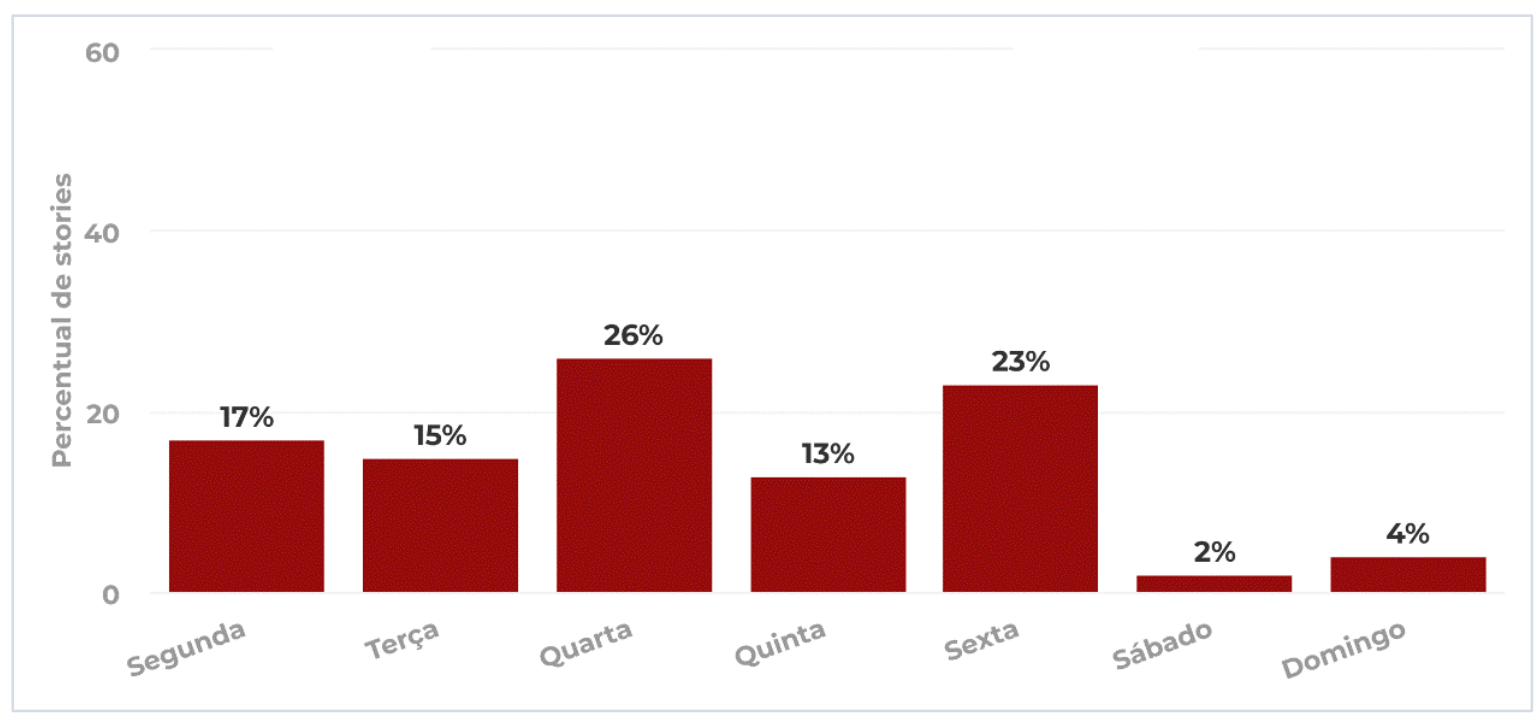

Fonte: elaborado pela autora (2020). 
No sábado e no domingo, a conta do jornal publicou apenas stories com conteúdo publicitário (figura 2.4), divulgando eventos em parceria com outras marcas e a divisão interna de projetos comerciais para anunciantes, o Estadão Media Lab.

Figura 2.4 - Finalidade dos stories do Estadão

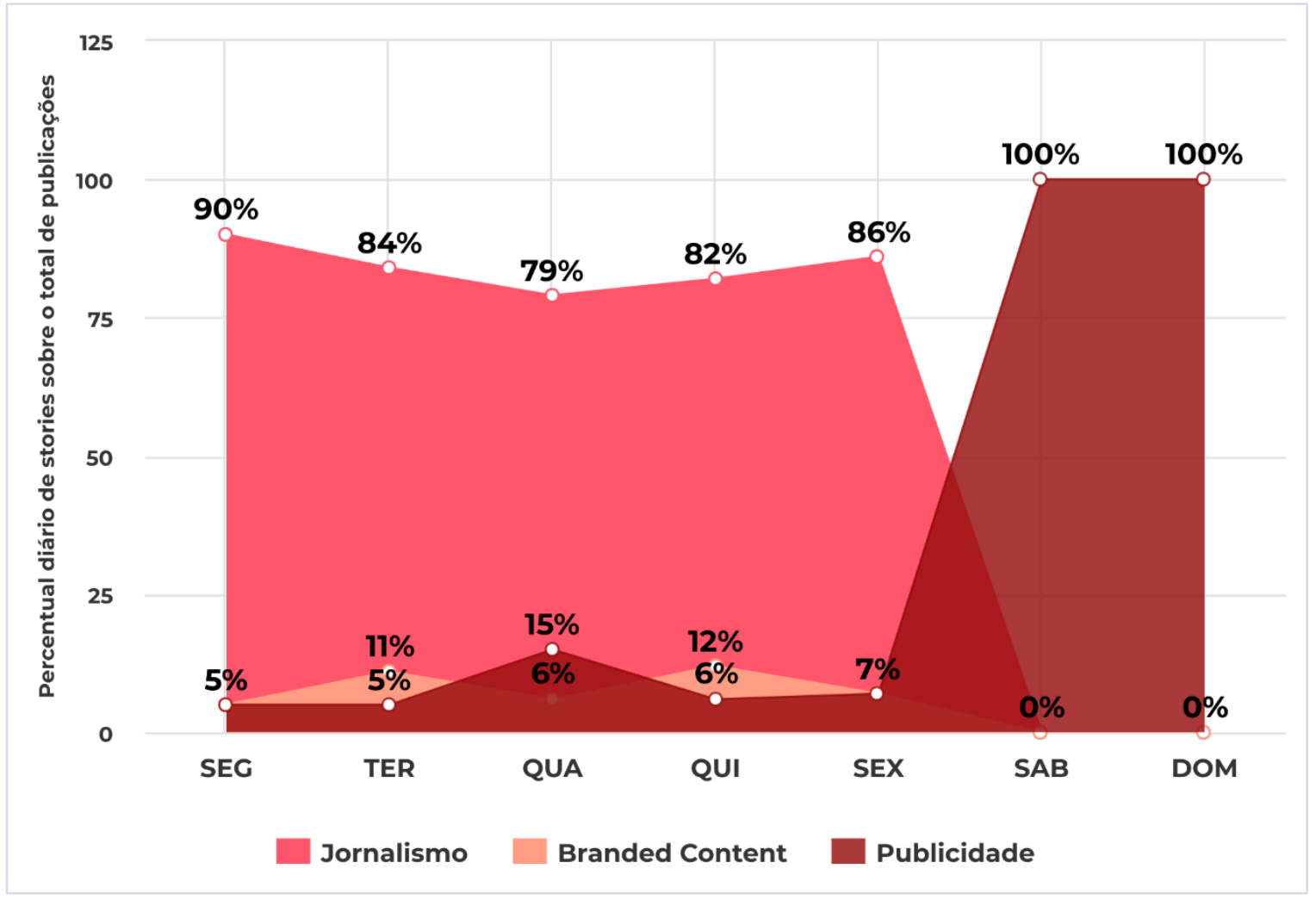

Fonte: elaborado pela autora (2020).

Dos 126 stories postados, 79,4\% eram referentes a conteúdo editorial, produzidos por jornalistas e sem aparente vínculo publicitário. Em segundo lugar, apareceram os stories explicitamente publicitários, correspondendo a $13,5 \%$ das publicações. Por último, apareceram os stories que divulgavam branded content $(7,1 \%$ do total).

Com relação à temática de conteúdo jornalístico e de branded content, houve uma predominância de stories ligados à cobertura da pandemia do novo coronavírus no Brasil e no mundo, com mais de um terço deles dedicados a isso. Política aparece em segundo lugar, presente em $22 \%$ das postagens e, em terceiro, cultura, com $18 \%$ do total (figura 2.5).

Quarta foi o dia com mais postagens, principalmente porque, apesar de haver proporcionalmente menos stories sobre política e economia, houve um aumento na 
presença de notícias internacionais e a respeito do coronavírus, com destaque para as mudanças da quarentena em São Paulo e a reabertura progressiva de estabelecimentos comerciais que estavam temporariamente suspensos desde março (RIBEIRO et al, 2020).

Figura 2.5 - Distribuição temática dos stories (jornalismo e branded content)

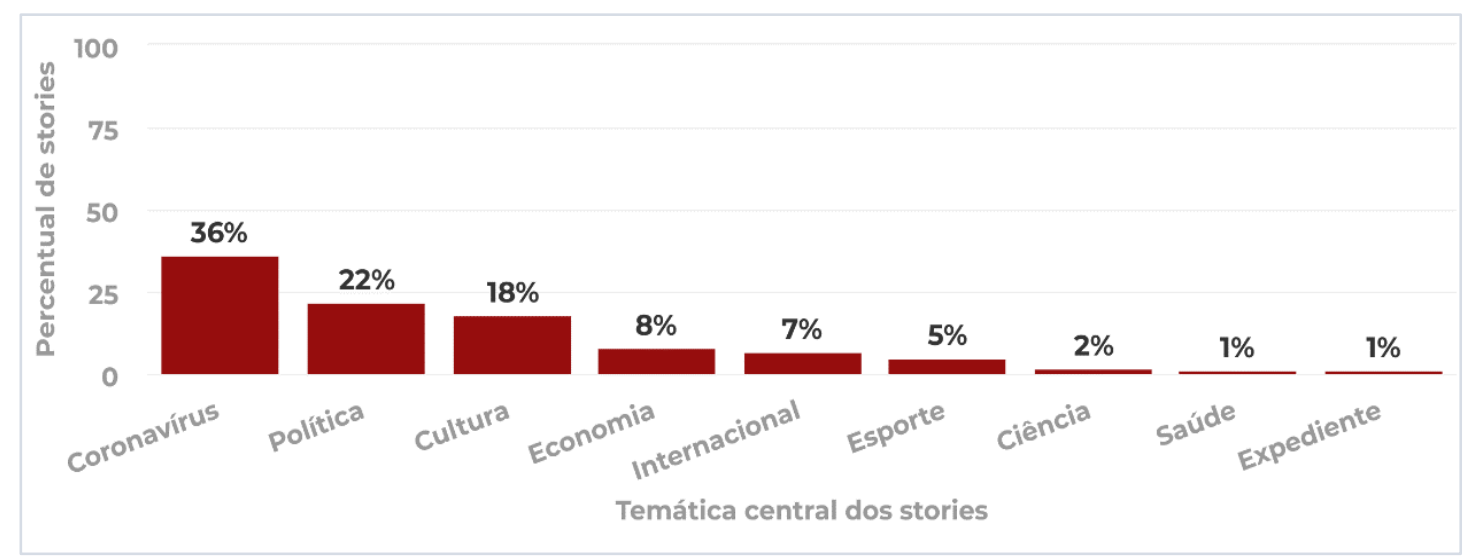

Fonte: elaborado pela autora (2020).

Como pode ser visto na figura 2.6, na quarta-feira o Estadão também fez mais postagens com temática cultural. Já na sexta-feira, segundo dia com mais postagens, percebeu-se a presença de conteúdos mais leves e direcionados ao entretenimento, com mais stories dedicados às editorias de cultura e assuntos internacionais.

Figura 2.6 - Percentual de stories diários das temáticas mais postadas no Estadão

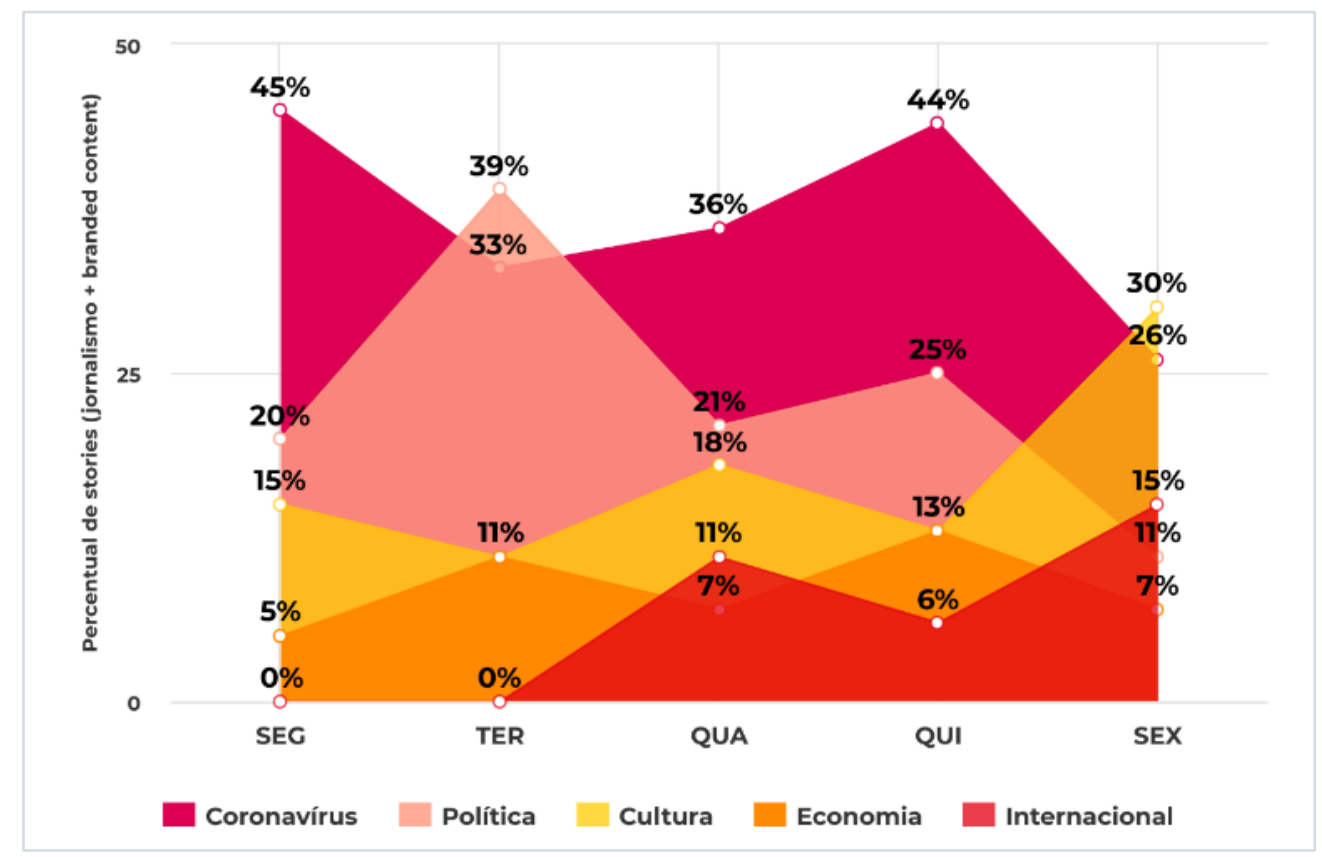

Fonte: elaborado pela autora (2020). 
O indicador E-27 nos deu um panorama dos assuntos mais abordados durante a semana. Com as principais palavras-chave presentes nos stories, montamos uma visualização fazendo uso de uma ferramenta gráfica chamada "nuvem de palavras" que mostra, a partir da recorrência de termos, quais são as expressões mais frequentes do conjunto.

A seguir, na figura 2.7, é possível ver que há um predomínio de termos ligados à pandemia ("COVID-19", "coronavírus", "quarentena") e, em seguida, à política ("Bolsonaro", "Trump”). "Brasil” aparece como uma das principais palavras-chave, assim como "Estadão".

Figura 2.7 - Recorrência de palavras-chave nos textos dos stories do Estadão

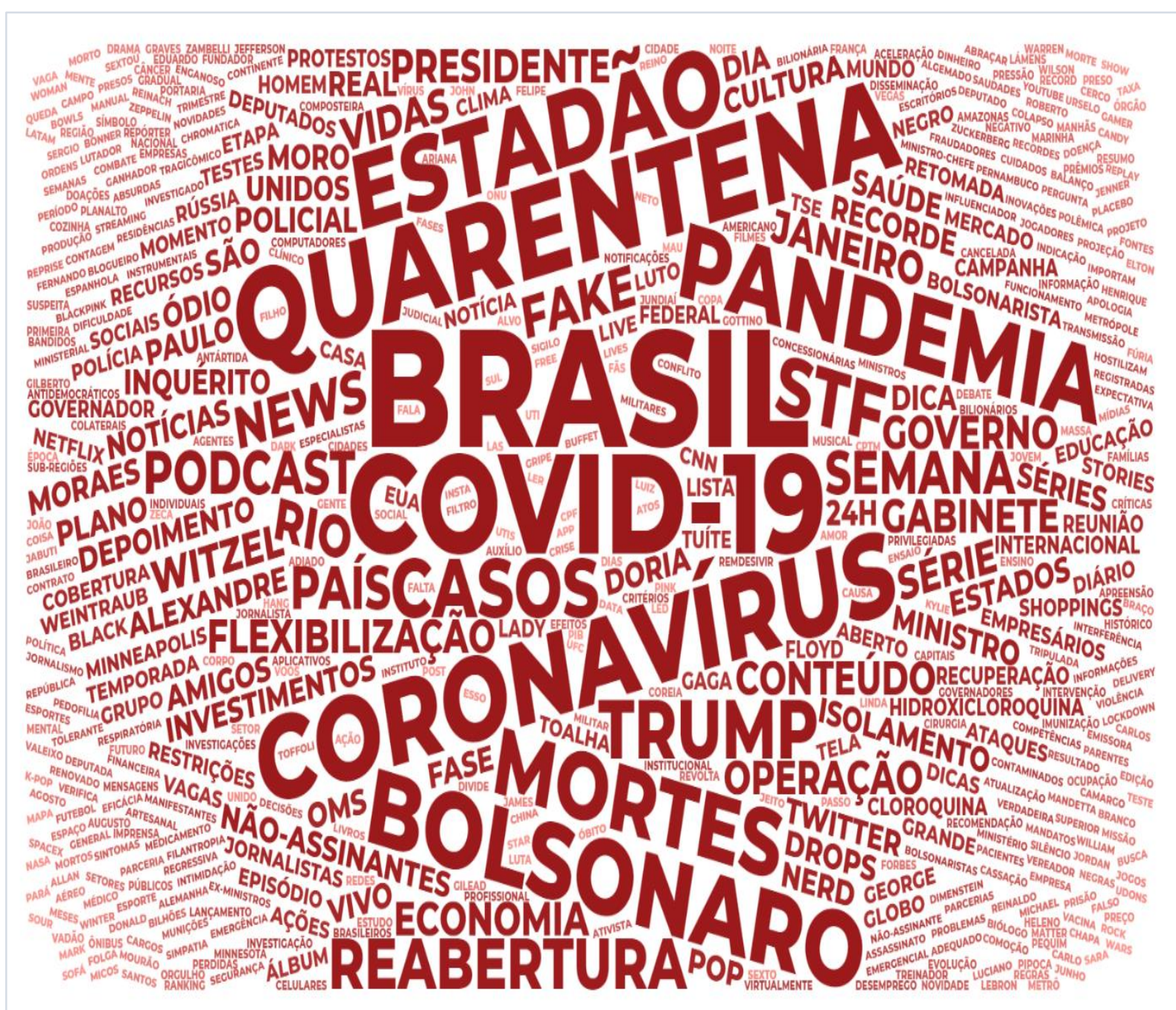

Fonte: elaborado pela autora (2020).

Quanto à aparência dos stories, no perfil do Estadão predominam as imagens com o estilo visualmente semelhante ao proporcionado pelo uso das ferramentas 
nativas de edição do Instagram (96\%) e na posição vertical em tela cheia (83\%), como pode ser visto na figura 2.8. Nela, percebe-se, com isso, uma preocupação em manter a aparência próxima a dos conteúdos costumeiramente produzidos pelos usuários do Instagram Stories, com um layout que acompanha a estética das ferramentas de edição disponíveis na própria plataforma.

Notamos, por outro lado, que os stories com design mais personalizado estão, em sua maioria, ligados à divulgação de conteúdos publicitários (fig. 2.9), com um layout mais complexo, mostrando um tratamento prévio de design gráfico para a promoção do evento anunciado.

Figura 2.8 e 2.9 - Tipos de layout presentes nos Stories do Estadão.

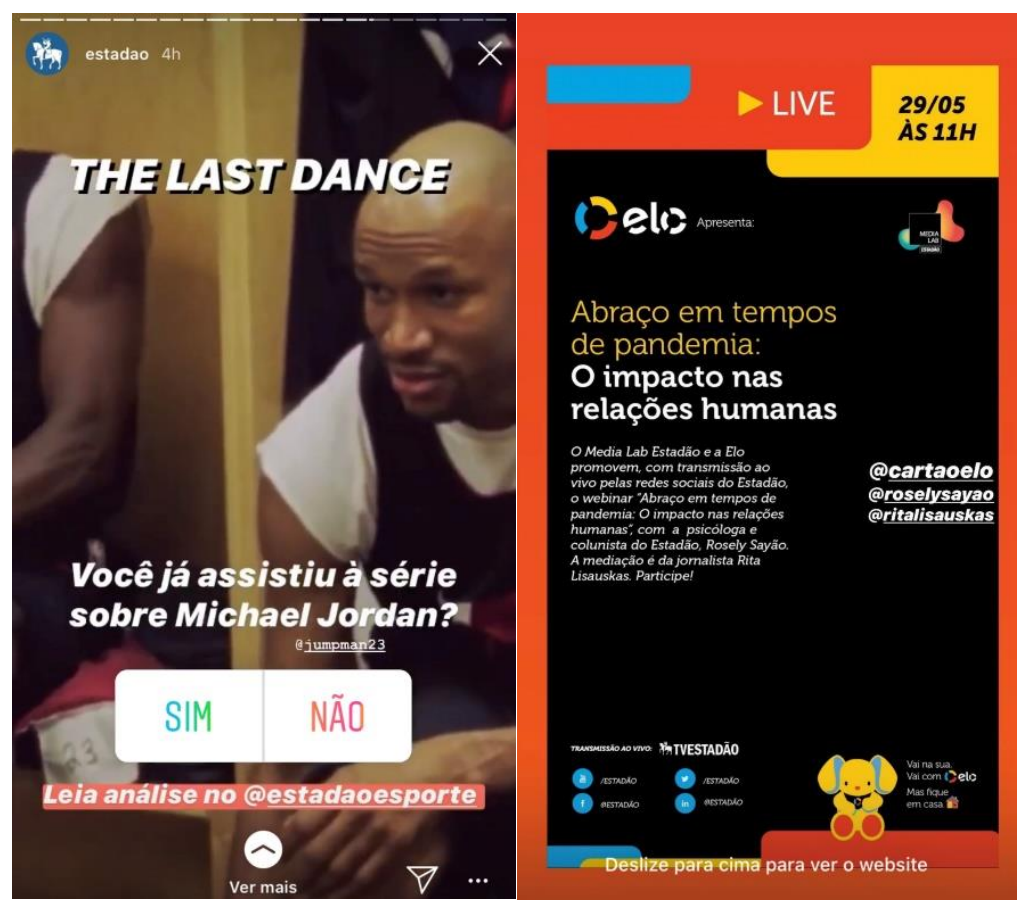

Fonte: captura de tela feita pela autora (2020)/ reprodução Instagram Stories do Estadão

No geral, não é possível afirmar que as edições de todas as imagens publicadas foram feitas exclusivamente dentro do aplicativo, uma vez que alguns stories possuíam vídeos com cortes que podem ter sido previamente editados em outros programas externamente.

Para entender o tipo de imagem utilizada pelos jornais, os indicadores $\mathrm{E}-17$, E-18 e E-19 versavam sobre a origem do material. A classificação foi feita a partir de dedução com base nas características da própria imagem e do texto que a acompanhava. Reconhecemos a fragilidade dessa classificação, visto que eram 
poucas (para não dizer praticamente inexistentes) as fotografias, vídeos e ilustrações que realmente continham o crédito com a fonte apropriada.

Usando esses parâmetros, percebemos que mais da metade das imagens utilizadas pelo perfil do Estadão (53\%), eram reproduzidas e não-originais: emojis, gifs, capturas de telas em sites de redes sociais ou mesmo do site do jornal. Cerca de $42 \%$ das figuras partiam de fontes jornalísticas, assim descritas por ter a aparência mais formal ou com maior resolução (qualidade de imagem).

Os vídeos gravados pelos próprios jornalistas para comentar as matérias também foram considerados material jornalístico por se tratar de conteúdo original e destinado a fins editoriais, apesar de apresentarem qualidade reduzida devido à captura com a câmera frontal de smartphones ${ }^{53}$.

$\mathrm{Na}$ coleta, observamos que $26 \%$ dos stories utilizavam filtros. Os filtros que modificam a aparência das imagens nem sempre colaboraram para a leitura das informações. Do total de stories publicados pelo Estadão, 11\% ficou de fora dessa classificação, pois eram imagens que continham filtros de fotos que impossibilitavam a identificação do conteúdo.

Mais de dois terços dos stories (67\%) possuíam a presença de pelo menos uma figura humana, seja em fotos, vídeos ou mesmo em gifs. Ainda sobre tipos de imagens, mais de $40 \%$ das publicações apresentaram pelo menos um gif ou emoji. Muitas dessas figuras eram animadas e, considerando conteúdo de vídeo também, vimos que $61 \%$ dos stories do Estadão exibiam algum tipo de movimento (imagens não-estáticas).

A média de palavras usadas em cada story ficou em 21,3 palavras por publicação. Entre texto e áudio, o texto sai na frente como a forma mais utilizada para transmitir informações, presente em todas as publicações, inclusive em stories com áudio.

Apesar de não chegar a $50 \%$ dos stories, o uso de som é significativo no perfil do Estadão, aparecendo em 44\% das postagens. Além da voz dos repórteres, observamos a utilização de músicas e de áudio original de vídeos reproduzidos de outras fontes.

Outra presença importante nos stories é a de links. Praticamente todos os stories do Estadão (97\%) possuíam a indicação de uma ligação externa à plataforma.

${ }^{53}$ No item 3.3.1 abordaremos o conceito de "jornalista selfie", relacionado a essa prática. 
A exceção, em $3 \%$ das postagens, deveu-se ao uso da caixa de mensagens diretas (que ocupa o mesmo espaço para links na parte inferior do story).

Um fato a se notar, com ocorrência em $65 \%$ dos stories com conteúdos jornalísticos e de branded content, é a semelhança entre o texto do story ao texto presente no site da marca. A análise de conteúdo mostrou que, em muitos casos, a escrita reproduzia literalmente a mesma chamada dos títulos e subtítulos das matérias (figura 2.10 e 2.11). À esquerda, na figura 2.10, aparece um story publicado com uma frase sobre a pandemia. Já na figura 2.11, à direita, vê-se que a mesma frase está também presente no título da matéria.

Figura 2.10 e 2.11 - Texto do Instagram semelhante ao texto do site do Estadão
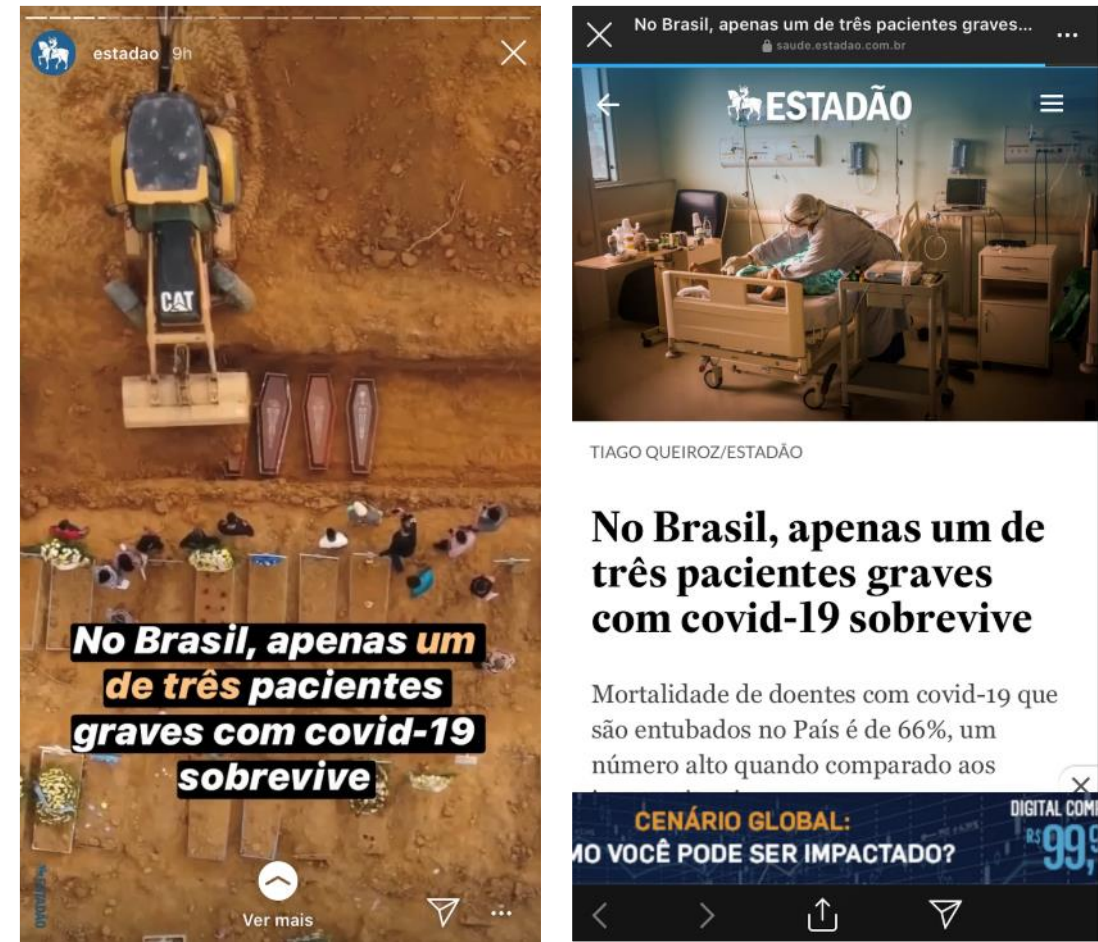

TIAGO QUEIROZ/ESTADĀO

No Brasil, apenas um de três pacientes graves com covid-19 sobrevive

Mortalidade de doentes com covid-19 que

são entubados no País é de $66 \%$, um número alto quando comparado aos

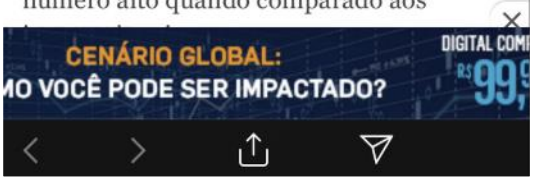

Fonte: captura de tela feita pela autora (2020)/ reprodução Instagram Stories do Estadão

Além dessa observação, durante a utilização da plataforma, acessamos todos os links e classificamos cada tipo dependendo da direção dada por eles (figura 2.12).

Cerca de $65 \%$ das publicações eram endereçadas a links com paywall. Com o objetivo de prestar informações à ampla população sobre a pandemia, o Estadão manteve parte de seus links sobre a temática sem o paywall (17\% dos stories). 
Também estavam abertas as publicações que direcionavam para conteúdos de branded content do E-Investidor ${ }^{54}$.

Para promover podcasts e outras maneiras de acessar o Estadão, cerca de 10\% dos links levavam a audiência para outros aplicativos (Spotify e App Store).

Figura 2.12 - Percentual de hiperlinks nos stories do Estadão (total semanal)

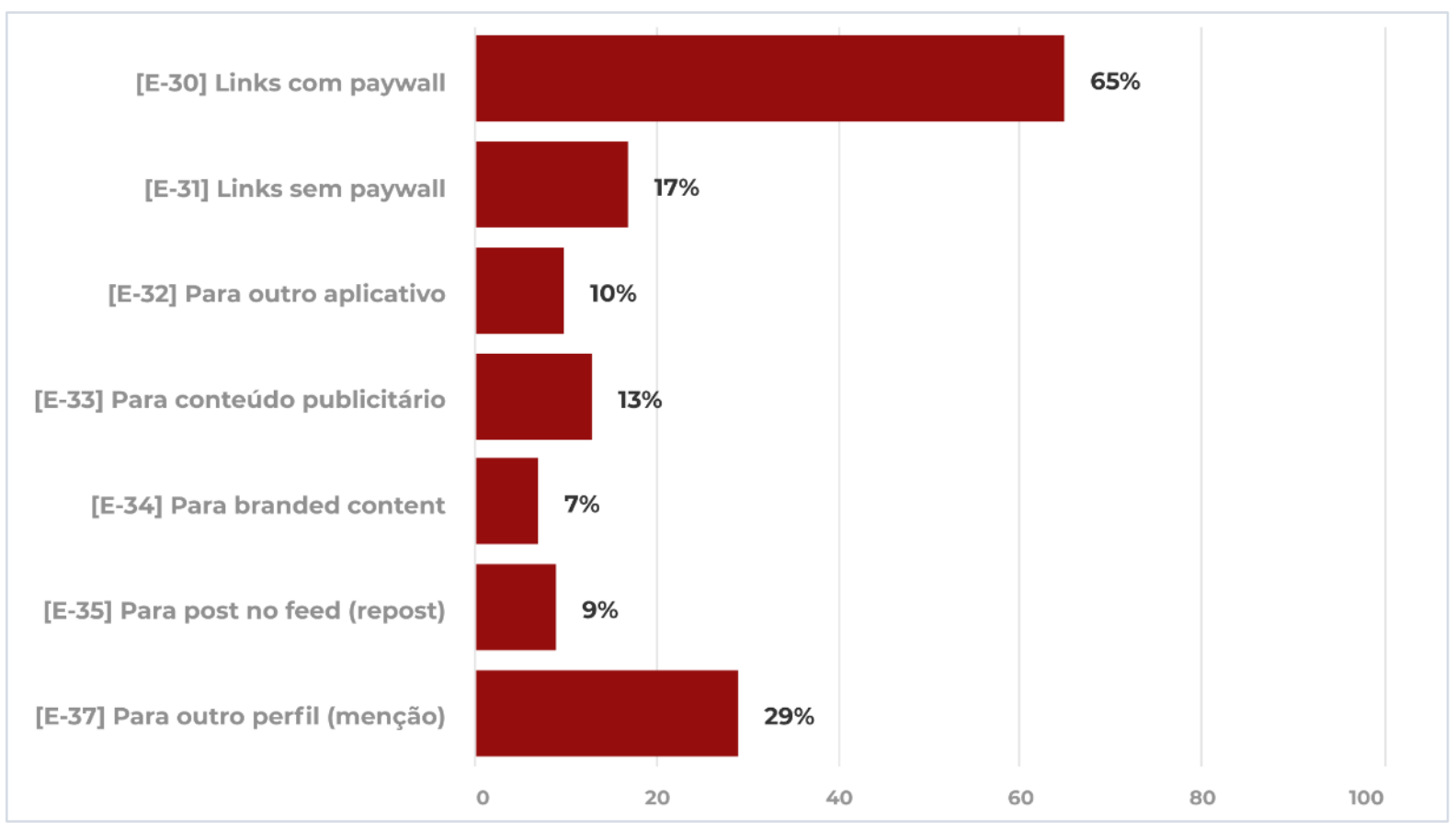

Fonte: elaborado pela autora (2020)

Todos os dias havia pelo menos um story que utilizava o recurso de repostagem (repost) e levava a audiência para a galeria permanente (feed) da marca. Esses stories também possuíam links para o site com conteúdo relacionado ao tema.

Outra aplicação de hiperlinks, através do recurso "menções", foi utilizada para direcionar a audiência para outros perfis dentro do próprio Instagram. Com essa ferramenta, o jornal marcou principalmente jornalistas da própria empresa, celebridades e outras marcas (quando se tratava de conteúdo publicitário).

Mais de $10 \%$ das postagens do Estadão envolviam publicidade, com grande parte delas integrada ao Instagram 55 . Apesar do grande potencial para a interatividade

$54 \mathrm{O}$ E-Investidor é um site de branded content com notícias sobre economia que o Estadão mantém em parceria com a empresa Ágora Investimentos. Mais informações disponíveis em: https://www.abcdacomunicacao.com.br/grupo-estado-e-agora-investimentos-se-unem-para-proverconteudo-financeiro-diferenciado-para-investidores/

${ }^{55}$ No terceiro capítulo aprofundaremos a questão do financiamento da atividade jornalística por meio dos stories no tópico 3.3. 
na plataforma, apenas $14 \%$ dos stories continham algum elemento que gerava engajamento e diálogo com o emissor, como as funções de enquetes, contagensregressiva ou etiquetas de perguntas. ${ }^{56}$

\subsubsection{FOLHA}

A conta oficial do jornal Folha de S. Paulo publicou, durante a semana analisada, 211 stories. O período do dia com mais postagens foi o da noite, após as $18 \mathrm{~h}$, com $65 \%$ do total. O segundo com mais publicações foi o da manhã, com $21 \%$. No período da tarde, das $12 \mathrm{~h}$ às $18 \mathrm{~h}$, o jornal postou $14 \%$ dos stories.

A distribuição semanal dos stories da Folha mostra um predomínio de postagens em dias úteis da semana e uma queda do percentual no sábado e no domingo (figura 2.13).

\section{Figura 2.13 - Gráfico de distribuição semanal dos stories da Folha}

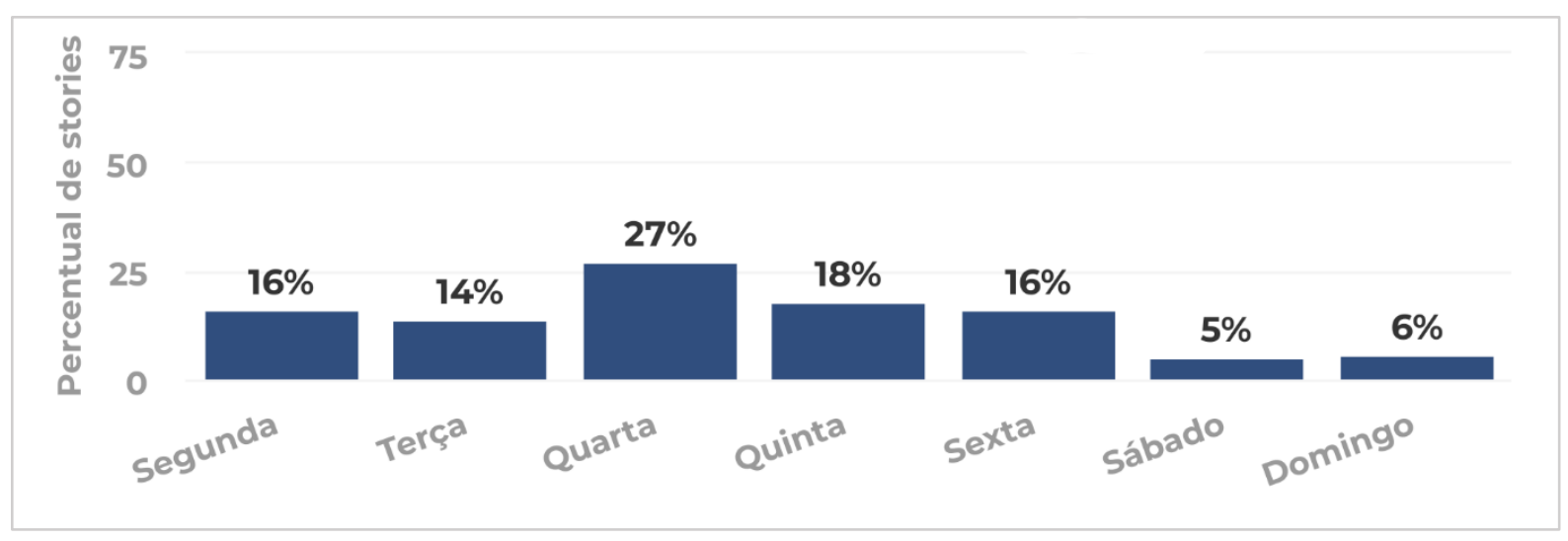

Fonte: elaborado pela autora (2020).

Quarta-feira foi o dia com mais postagens, principalmente porque a Folha divulgou a cobertura de uma operação da Polícia Federal envolvendo deputados federais em um esquema de fake news (FABRINI, 2020), publicada no período da manhã, fora da publicação habitual do resumo de notícias feito à noite. Foram 23 stories com links para notícias relacionadas ao fato, alguns deles com a palavra "urgente" junto ao texto da chamada. Somados às demais publicações, a quarta

56 Nesse indicador descartamos a função de "compartilhamento", representada pelo ícone de aviãozinho de papel localizado na parte inferior do story por esse recurso estar presente em todas as publicações analisadas, sendo adotado por padrão no perfil do jornal. Falaremos mais sobre interatividade no tópico 3.2 . 
totalizou 55 stories, enquanto a quantidade publicada nos outros dias úteis da semana variou de 28 a 37 stories.

Dos 211 stories postados, 86\% eram referentes a conteúdo editorial, produzidos por jornalistas e sem aparente vínculo publicitário. Em segundo lugar, aparecem os stories que divulgavam branded content ( $9 \%$ do total). Por último, os explicitamente publicitários, correspondendo a 5\% das publicações (figura 2.14).

Figura 2.14 - Finalidade dos stories da Folha por dia da semana

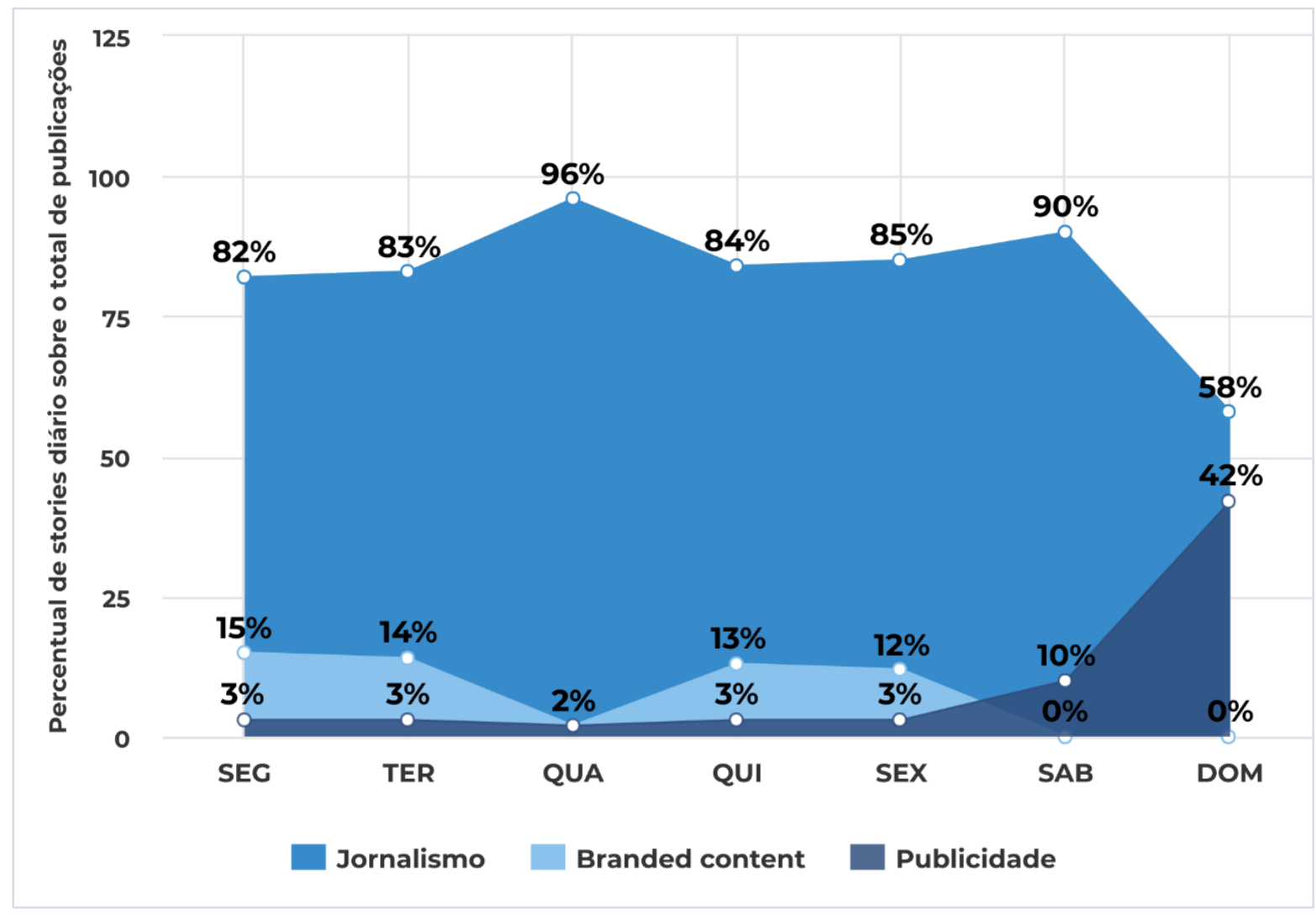

Fonte: elaborado pela autora (2020).

Com relação à temática de conteúdo jornalístico e de branded content, houve uma predominância de stories ligados à política, com $45 \%$ dos stories dedicados ao tema. A cobertura da pandemia do novo coronavírus no Brasil e no mundo ficou em segundo lugar, presente em $23 \%$ das postagens e, em terceiro, assuntos internacionais, com 13\% do total (figura 2.15). 
Figura 2.15 - Distribuição temática dos stories (jornalismo e branded content) da Folha

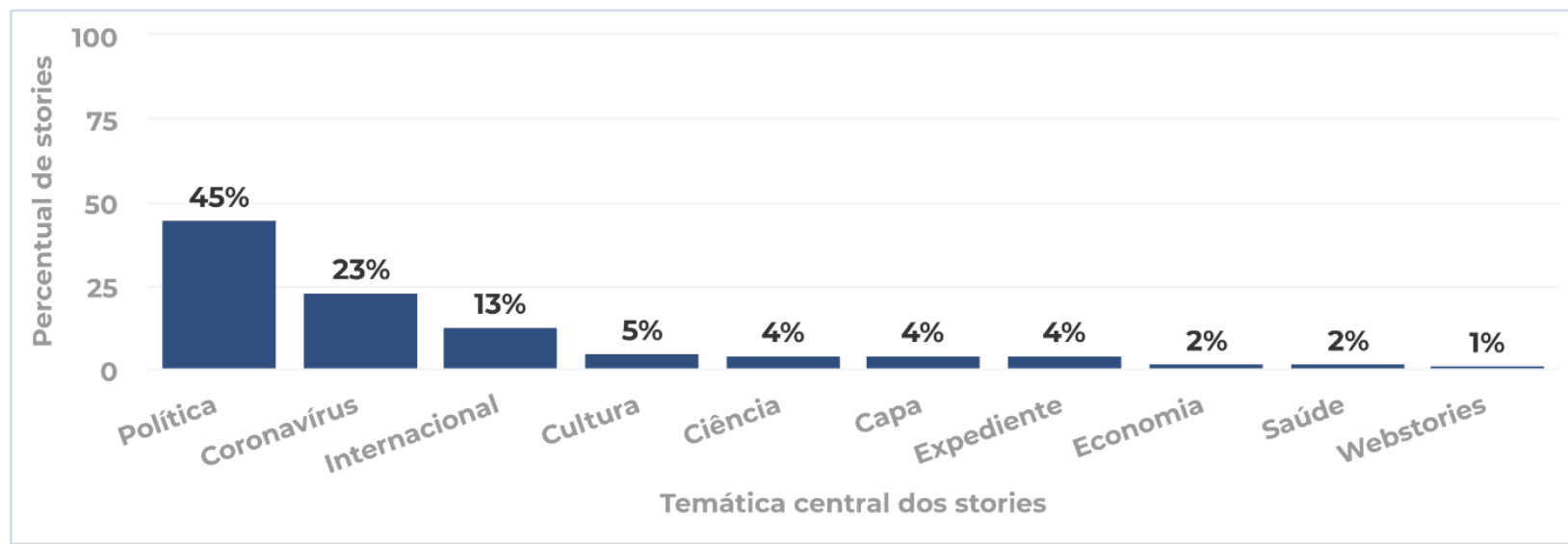

Fonte: elaborado pela autora (2020).

Como pode ser visto no gráfico a seguir (figura 2.16), na quinta-feira a Folha teve um pico de postagens sobre o coronavírus. Já na sexta, as temáticas mais exploradas foram relacionadas à cultura e a assuntos internacionais, principalmente sobre protestos após a morte brutal de um homem negro por um policial branco nos Estados Unidos (DIAS; BALAGO, 2020) ${ }^{57}$.

Figura 2.16 - Percentual de stories diários das temáticas mais postadas na Folha

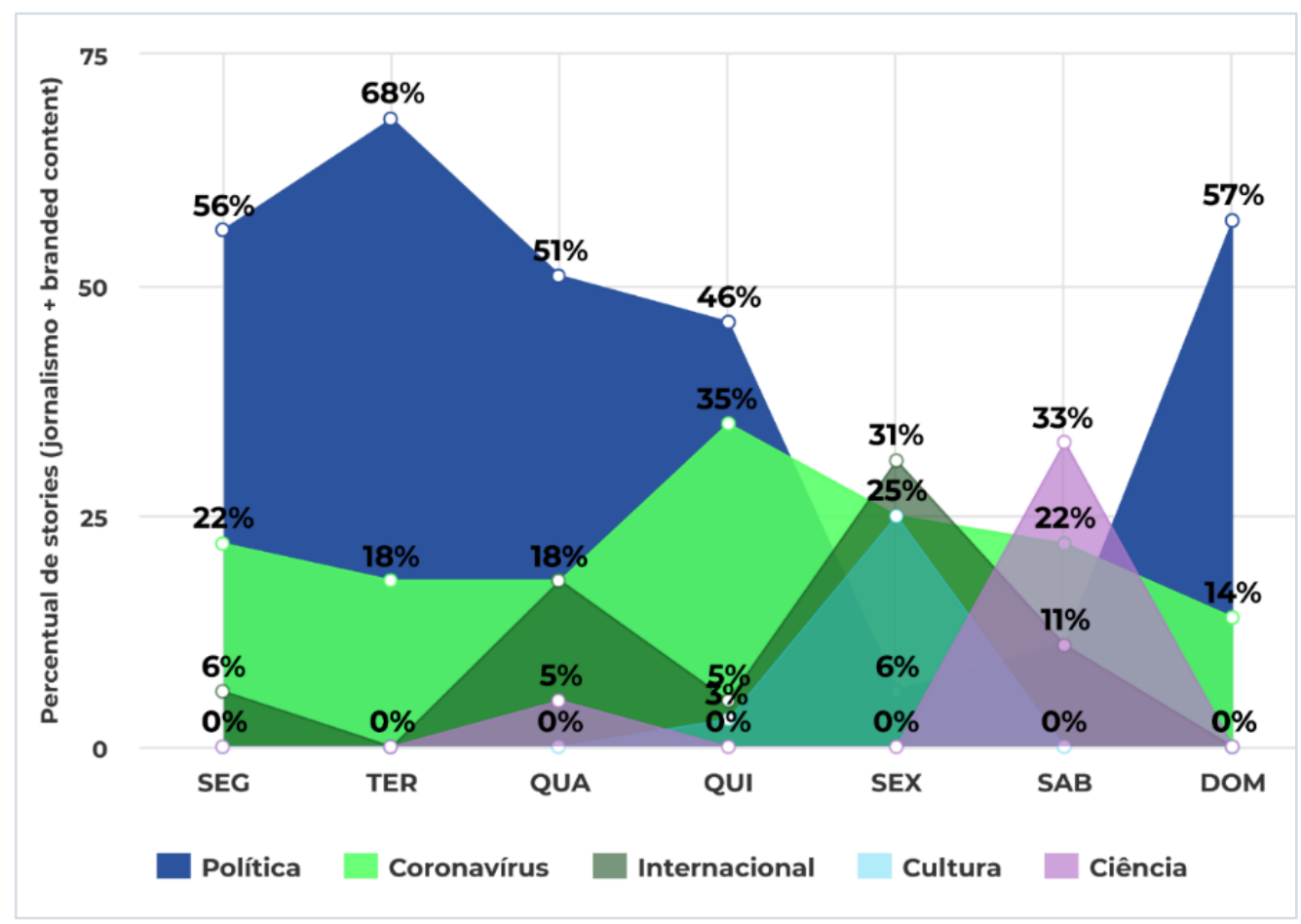

Fonte: elaborado pela autora (2020).

${ }^{57}$ Mais informações sobre elementos interativos na cobertura do caso serão tratadas no item 3.1.2. 
A figura 2.17, que mostra as palavras-chave mais repetidas durante a semana nos stories, mostra em destaque o nome da vítima, "George Floyd" e as palavras "manifestantes", "negro", "policial” e "Minneapolis". No sábado houve o predomínio de publicações relacionadas à ciência em função da cobertura do lançamento do foguete da SpaceX, que fez história por ter sido a primeira empresa privada a ter uma tripulação em órbita (FOLHA, 2020) ("SpaceX" e "astronautas" também aparecem como dois dos termos mais citados na semana).

No geral, é possível ver que há um predomínio de expressões ligadas à política nacional ("Bolsonaro", “operação”, "Witzel”, "Polícia Federal”) e, em seguida, à cobertura da pandemia ("coronavírus", "mortes", "casos", "COVID-19"). "Brasil" aparece como uma das principais palavras-chave, assim como "Folha".

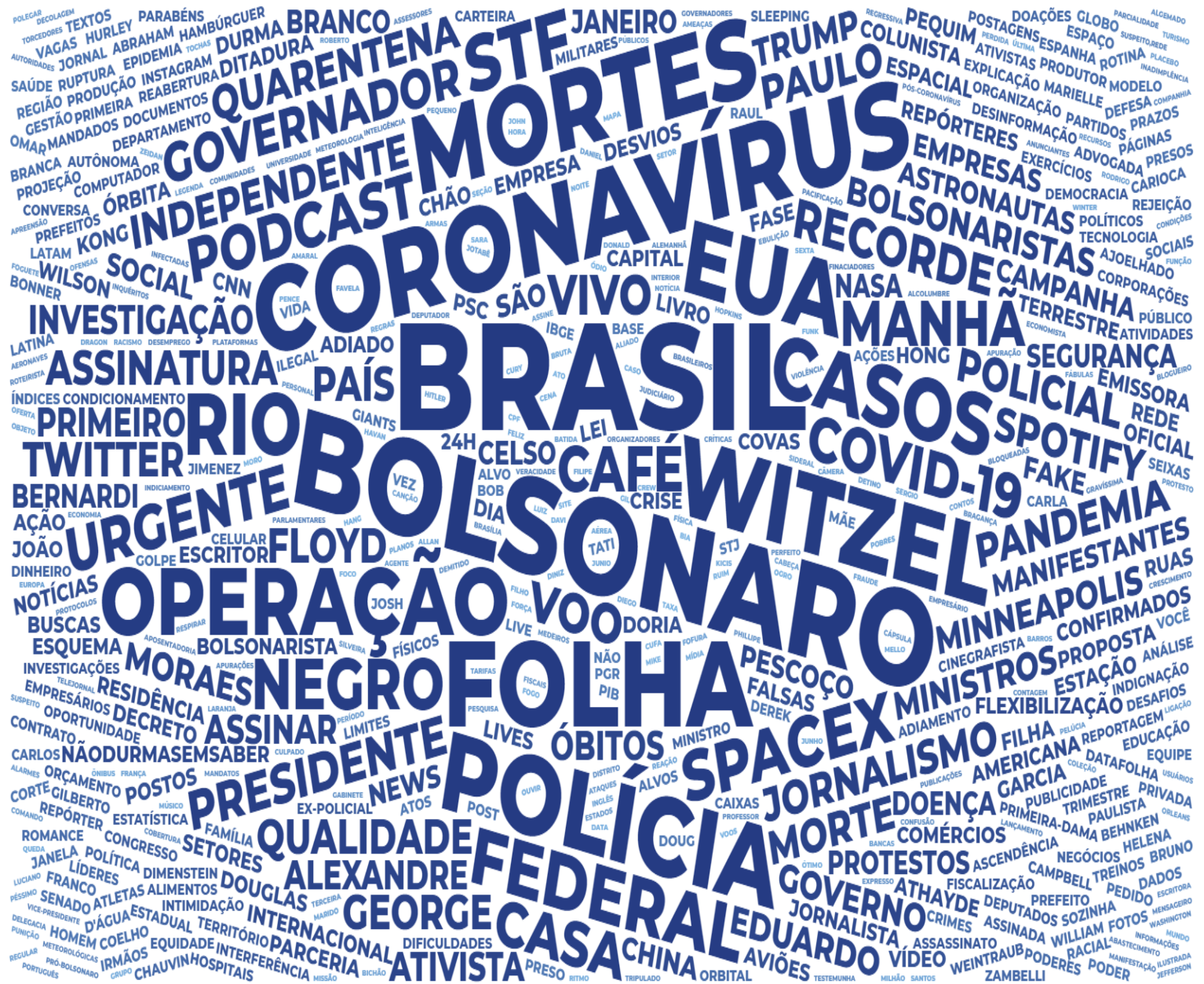

Fonte: elaborado pela autora (2020). 
No perfil da Folha, predominam as imagens com o estilo visualmente semelhante ao proporcionado pelo uso das ferramentas nativas de edição do Instagram (93\%) e com fotografias na posição horizontal/paisagem (59\%), como pode ser visto na figura 2.18), em que o layout do story acompanha a estética de publicações das ferramentas de edição da própria plataforma, com a imagem no formato paisagem/horizontal.

Notamos, também, que os stories com design mais personalizado estão, em sua maioria, ligados à divulgação de conteúdos especiais, como podcasts (figura 2.19) e entrevistas ao vivo transmitidas pelas redes sociais da marca, também conhecidas como lives (figura 2.20), contando com um tratamento prévio de design gráfico para a promoção dos temas anunciados.

Figura 2.18, 2.19 e 2.20 - Tipos de layout presentes nos Stories da Folha
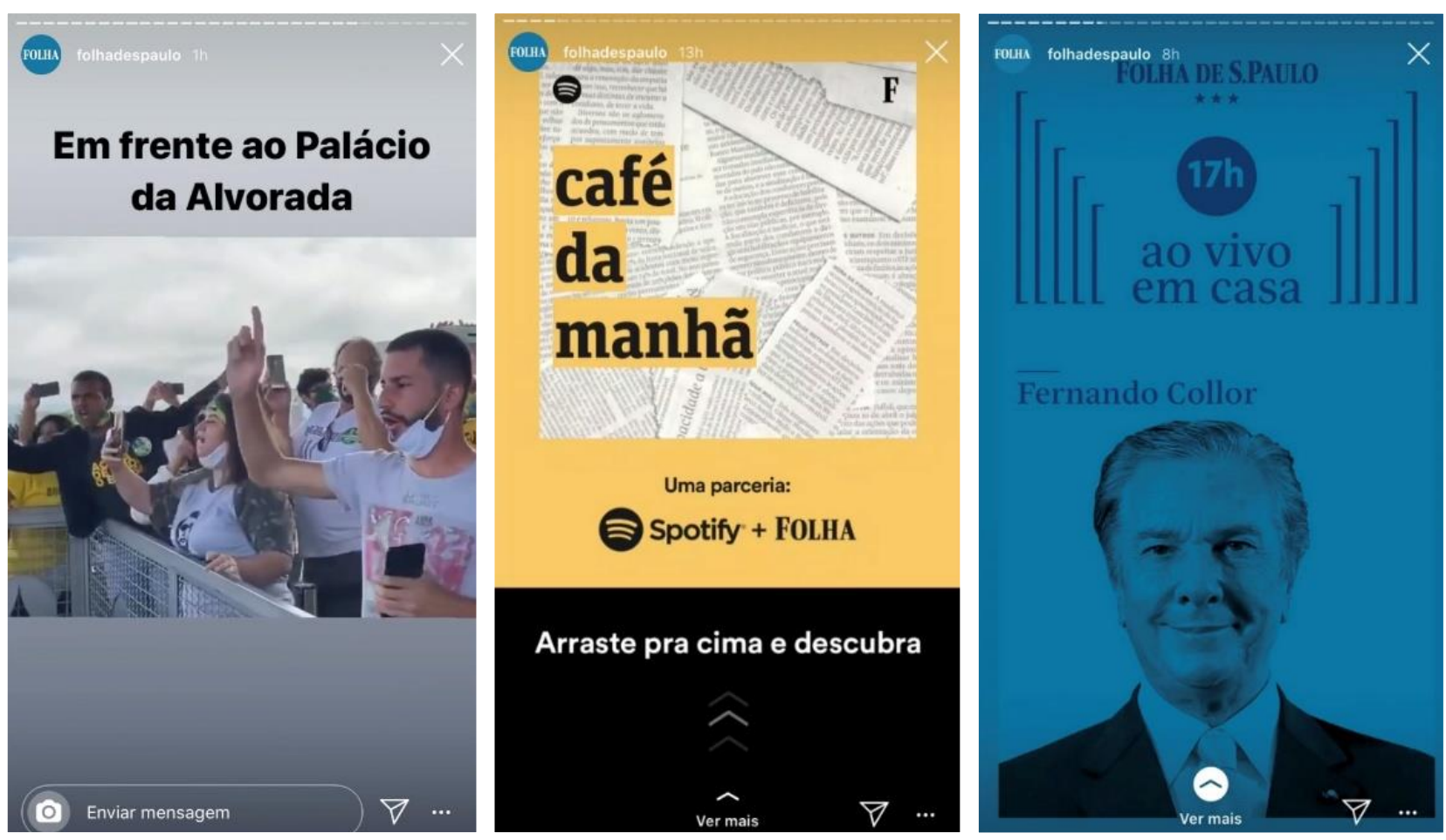

Fonte: captura de tela feita pela autora (2020)/ reprodução Instagram Stories da Folha 
Percebemos que $26 \%$ das imagens utilizadas pelo perfil da Folha eram reproduzidas e não-originais: emojis, gifs, capturas de telas em sites de redes sociais online ou mesmo do site do jornal. Cerca de 60\% das figuras partiam de fontes jornalísticas, assim descritas por ter a aparência mais formal ou com maior resolução (qualidade de imagem). Do total, 9\% ficou de fora dessa classificação, pois eram imagens que continham filtros que impossibilitavam a identificação do conteúdo.

$\mathrm{Na}$ coleta, observamos que $16 \%$ do total de stories utilizavam filtros. Apenas cerca de $7 \%$ do total de stories continham algum elemento interativo, como as funções de enquete ou de mensagem direta. ${ }^{58}$

Dois terços dos stories (66\%) possuíam a presença de pelo menos uma figura humana, seja em fotos, vídeos ou mesmo em gifs.

Observando apenas os elementos imagéticos, vimos que $19 \%$ das publicações apresentaram pelo menos um gif ou emoji. Algumas dessas figuras eram animadas e, considerando conteúdo de vídeo também, vimos que apenas $21 \%$ dos stories do Folha exibiam algum tipo de movimento. A maioria era composta por stories estáticos, apenas com fotografias.

Somadas as palavras do texto das publicações, a Folha teve uma média de 20,5 palavras por story. O uso de texto aparece em $100 \%$ das postagens da Folha, inclusive em stories com áudio.

Houve apenas um dia com conteúdo audiovisual, com dois vídeos que mostravam pessoas em frente ao Palácio do Planalto e ao Ministério da Defesa, em Brasília, lançando ofensas a jornalistas (FOLHA, 2020b). Comparado à amostra total, essa ocorrência não chega a 0,5\%.

Uma importante função utilizada nos stories da Folha é a de links (figura 2.21). Mais de $90 \%$ dos stories possuíam a indicação de uma ligação externa à plataforma. A exceção, em aproximadamente $7 \%$ das postagens, deveu-se ao uso da caixa de mensagens diretas (que ocupa o mesmo espaço para links na parte inferior do story). 
Figura 2.21 - Percentual de hiperlinks nos stories da Folha (total semanal)

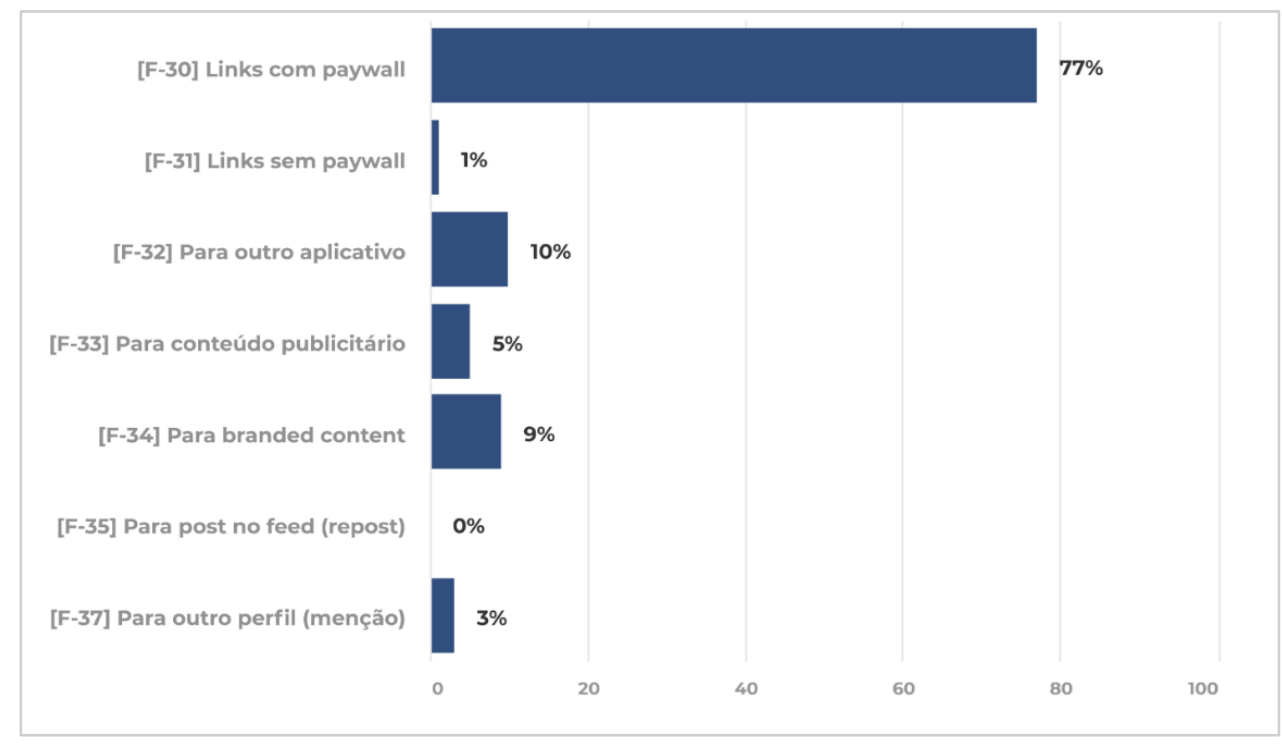

Fonte: elaborado pela autora (2020).

Cerca de $77 \%$ das publicações eram endereçadas a links com paywall. Dos 181 stories que possuíam conteúdos jornalísticos ao site da Folha, apenas dois estavam fora do paywall e correspondiam a uma chamada para um formato recente de visualização de notícias, as web stories ${ }^{59}$ (figura 2.22).

Figura 2.22- As web stories no site da Folha
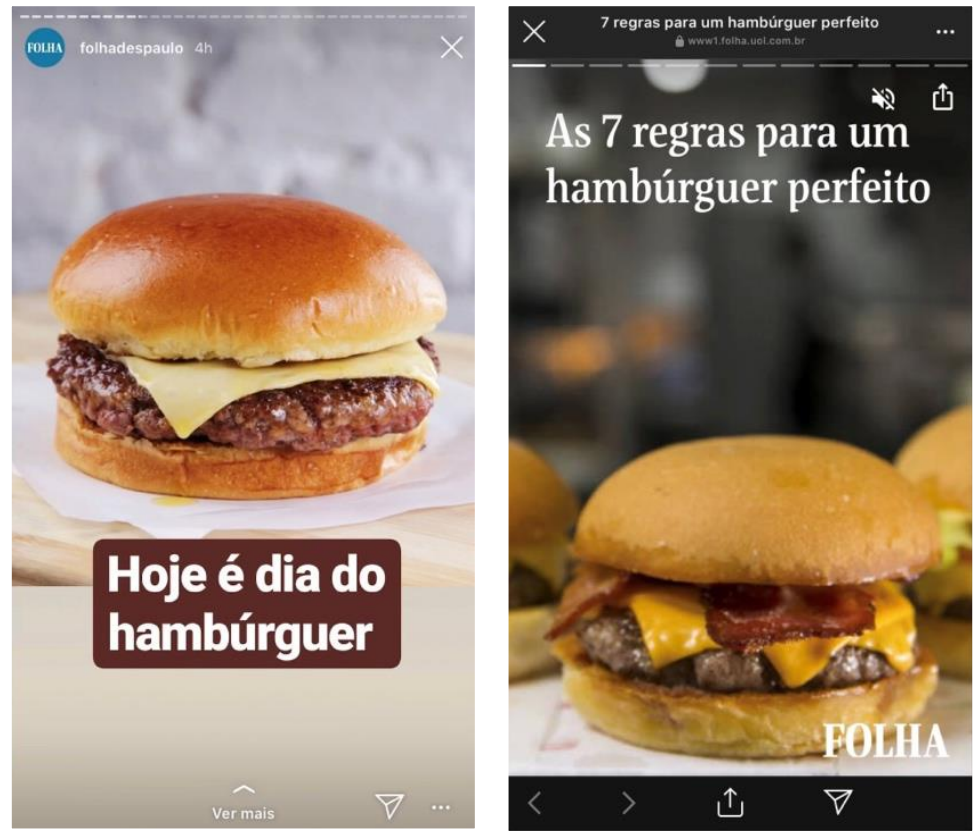

Fonte: captura de tela feita pela autora (2020)/ reprodução Instagram Stories da Folha

59 Lançado em 2018 e antes conhecido como AMP Stories, os Web Stories são os stories do Google. "Como se fossem slides verticais e com o uso de recursos como vídeos, animações, gifs, áudios, fotos e textos, os Web Stories permitem contar histórias de uma maneira mais dinâmica e imersiva" (FOLHA, 2020c). 
Com o recurso "menções", que direciona a audiência para outros perfis do Instagram, o jornal marcou em $3 \%$ das suas postagens jornalistas da própria empresa.

Outro dado relevante é o direcionamento para aplicativos de terceiros. Para promover podcasts e outras maneiras de acessar o conteúdo da Folha, cerca de 10\% dos links levavam a audiência ao Spotify60.

Apenas 11 stories da Folha envolviam publicidade: um story diário que direcionava para a página de assinatura do jornal e quatro stories publicados no domingo que divulgavam uma coleção de livros infantis.

A respeito dos textos presentes nos stories com conteúdos jornalísticos e de branded content, existe semelhança entre o conteúdo do textual do story e o do site. A análise de conteúdo mostrou que em $59 \%$ das postagens a escrita reproduzia totalmente ou parcialmente os títulos e subtítulos das matérias (figura 2.23).

Figura 2.23 - Texto do Instagram semelhante ao texto do site da Folha
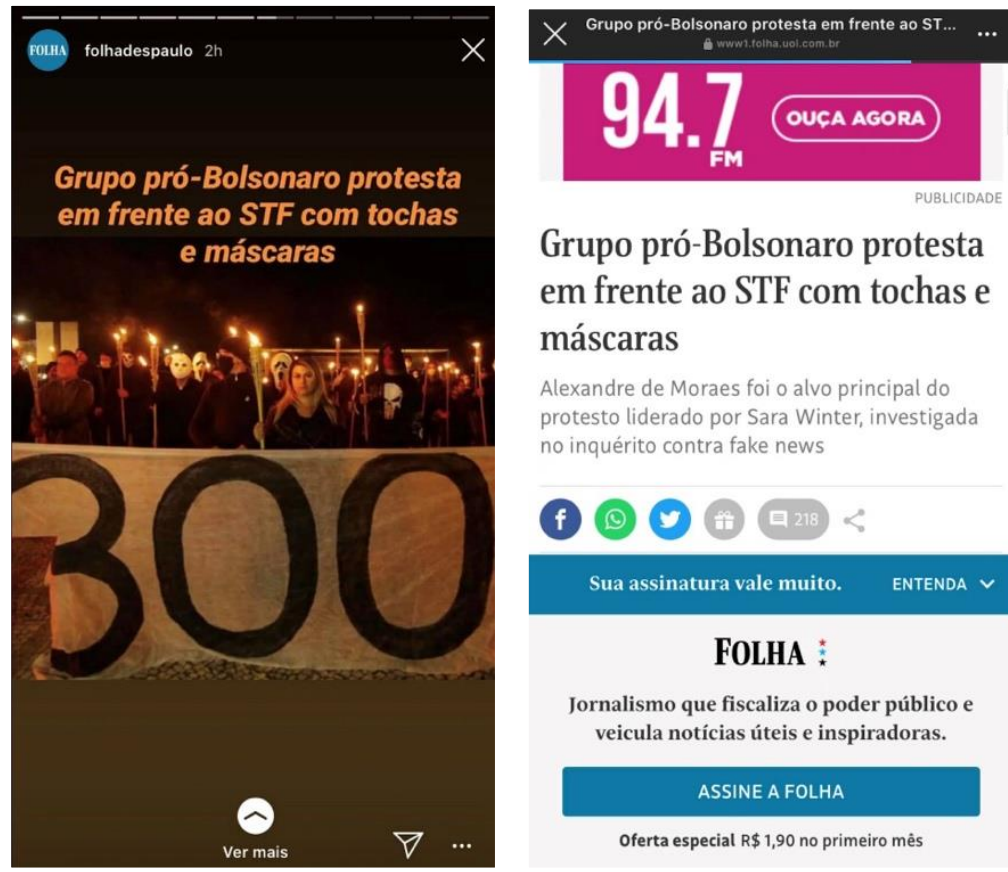

Grupo pró-Bolsonaro protesta em frente ao STF com tochas e máscaras

Alexandre de Moraes foi o alvo principal do protesto liderado por Sara Winter, investigada no inquérito contra fake news

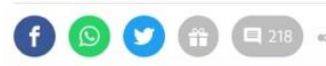

Sua assinatura vale muito. ENTENDA $\checkmark$

FOLHA :

Jornalismo que fiscaliza o poder público e veicula notícias úteis e inspiradoras.

\section{ASSINE A FOLHA}

Oferta especial $R \$ 1,90$ no primeiro mès

No próximo tópico examinaremos os dados da análise qualitativa, dando respostas às hipóteses iniciais, e apresentaremos as categorias criadas a partir das informações obtidas na coleta das amostras de stories dos dois jornais. 


\subsection{CARACTERÍSTICAS DA PRESENÇA JORNALÍSTICA NOS STORIES}

No tópico anterior, dispusemos os dados brutos de forma ordenada e condensada, respeitando os aspectos quantitativos da nossa análise para que tivéssemos condições de realizar a leitura das informações.

Após a etapa de exploração, Bardin (2016) aponta que o passo seguinte é o tratamento dos resultados. Caminhamos, portanto, para a inferência e a interpretação dos dados tabulados, construindo observações a partir de uma abordagem mais qualitativa das amostras.

Apresentaremos, a seguir, respostas para as hipóteses levantadas no início da análise de conteúdo. Mais à frente, encerraremos o segundo capítulo com a classificação das unidades de registro em categorias.

Figura 2.24 - Breve panorama da coleta de stories dos jornais

\section{Breve panorama da coleta de stories dos jornais}

FOLHA

\begin{tabular}{r|c|c} 
& & \\
211 stories & total & 156 stories \\
\hline + stories pela manhã e à noite & horário & + stories à tarde e à noite \\
\hline $93 \%$ dos stories & links & $97 \%$ dos stories \\
\hline + stories de política e coronavírus & assuntos & + coronavírus/política/entretenimento \\
\hline + foto, texto e imagem horizontal & formato & + vídeo, texto, áudio e imagem vertical \\
\hline $19 \%$ dos stories & emojis/gifs & $40 \%$ dos stories \\
\hline $7,1 \%$ dos stories & interação & $14 \%$ dos stories \\
\hline $16 \%$ dos stories & filtro & $26 \%$ dos stories \\
\hline $5 \%$ dos stories & publicidade & $13 \%$ dos stories
\end{tabular}

25-31 de maio de 2020

Fonte: elaborado pela autora (2020) 


\subsection{1 - RESPOSTAS ÀS HIPÓTESES DA ANÁLISE DE CONTEÚDO}

A partir do panorama dos dados obtidos na coleta, obtivemos algumas respostas ${ }^{61}$ para as hipóteses lançadas no item 2.2.2. Levamos em consideração uma síntese dos indicadores ${ }^{62}$ para formular as inferências aqui apresentadas.

Hipótese (a): A maioria dos stories são usados apenas como "iscas" para levar a audiência ao site da marca por meio de links integrados à imagem (indicadores F/E 29, 30, 31, 32, 33 e 34).

Dos 337 stories publicados nos sete dias de análise pela Folha e pelo Estadão, $94,6 \%$ possuíam links, sendo que $84,3 \%$ desse total direcionavam para os sites dos jornais. Com isso, podemos dizer que os stories são usados, em sua maioria, para levar o usuário do Instagram aos sites das marcas, mas não podemos dizer que essa é a única razão dessas publicações. Havia links que também direcionavam para outros aplicativos ou para conteúdos patrocinados.

Além disso, os dois jornais também apresentaram resumos das principais notícias, o que já oferecia alguma informação para a audiência sem a necessidade de abrir o link. Não conseguimos identificar todas as motivações que levam as empresas a publicarem na plataforma devido às limitações de nosso escopo de trabalho. É possível afirmar, por conta da alta incidência de links, que uma das principais razões é a capacidade de estender a presença da audiência nos stories para seus sites.

Hipótese (b): Pela plataforma usar o celular na vertical e privilegiar a imagem no formato retrato, a presença humana existe na maioria dos stories (indicadores F/E 04, 05 e 09).

Quando consideramos os stories que apresentam imagens verticais e que ocupam toda a tela do celular, vemos que $83 \%$ das postagens do no Estadão seguem essa característica. A ocorrência de figuras humanas nos stories da empresa corresponde a $67 \%$. Já a Folha, apesar de não apresentar a mesma quantidade de

\footnotetext{
${ }^{61}$ As respostas se aplicam às hipóteses construídas no período de análise, mas temos consciência de que o recorte de uma semana é limitado para explicações totalizantes ou permanentes a respeito da produção dos dois jornais. Reforçamos, ainda, que essas respostas não esgotam o campo de pesquisa para o objeto, principalmente porque o ambiente de stories, como vimos, é instável e sofre mudanças constantes.

62 Dos 40 indicadores analisados, apenas 27 respondem às hipóteses. Os demais foram utilizados para compor a descrição das amostras.
} 
imagens completamente verticais (apenas $41 \%$, os demais stories mostravam imagens predominantemente horizontais), demonstrou ter uma proporção de presença humana bem similar à do Estadão: $66 \%$.

Não conseguimos afirmar, entretanto, se isso se trata de um padrão dentro do ambiente dos stories ou mesmo no ambiente jornalístico, mas a semelhança entre os valores das duas empresas chamou a nossa atenção. Por meio dos dados analisados, não conseguimos dizer se existe uma relação direta entre a quantidade de imagens no formato retrato e a quantidade de presença humana na tela.

Hipótese (c): A informação que é passada nos stories reproduz de forma muito semelhante ou igual o texto do título e do subtítulo das matérias jornalísticas para onde os links levam (indicador F/E 26).

Descobrimos na análise que existe uma similaridade significativa entre a quantidade de stories que fazem uso de textos semelhantes nos perfis dos dois jornais. No Estadão foram 65\%, na Folha, 59\%. Quando consideramos apenas os stories editoriais e de branded content, esse número sobe para $75 \%$ e $62 \%$, respectivamente.

Hipótese (d): Os assuntos tratados variam conforme o dia da semana (indicador F/E 13).

Essa hipótese se mostrou verdadeira. De fato, notamos a diferença de assuntos principalmente na sexta-feira e no final de semana. De sexta, em ambos os jornais há maior proporção de stories dedicados à cultura (com temas relacionados ao lazer e ao entretenimento) e ao noticiário internacional, com queda na proporção de temas políticos e sobre o coronavírus.

No final de semana analisado, houve a diminuição de assuntos jornalísticos abordados e o aumento de postagens de cunho comercial. No caso do Estadão, não houve conteúdo editorial no sábado e no domingo, apenas publicitário. Já a Folha utilizou, no domingo, o espaço para divulgar uma coleção de livros à venda. O jornal manteve o conteúdo jornalístico, mas em menor quantidade se comparado aos dias de semana. 
Hipótese (e): Algumas editorias são mais privilegiadas do que outras na frequência de aparição nos stories. (indicador F/E 13).

Constatamos que houve o predomínio de publicações relacionadas à política e à cobertura do coronavírus em ambos os jornais. As duas temáticas ocuparam as primeiras posições na lista de assuntos mais abordados na semana. Considerando apenas o conteúdo editorial e de branded content, o Estadão apresentou 36\% de stories sobre a pandemia e $22 \%$ sobre política. Na Folha a situação é semelhante, mas as posições se invertem. Foram $45 \%$ dos stories sobre política e $23 \%$ sobre o avanço da COVID-19 pelo mundo. Acrescentamos o fato de que o Estadão também possui relevância quanto à quantidade de stories publicados sobre entretenimento dentro da editoria de cultura, com $20 \%$.

Hipótese (f): Fica claro para a audiência quando o jornal usa publicidade dentro dos stories (indicadores F/E 10, 11, 12)

No geral, todos os stories publicitários apresentaram marcas visuais que indicavam a relação com anunciantes. Porém, no caso de branded content, essa linha fica mais tênue e nem todas as parcerias são indicadas, como é o caso, já citado no tópico anterior, da produção de branded content para a empresa Ágora Investimentos por meio do portal E-investidor do Estadão. É possível encontrar a informação de produção patrocinada apenas em seu site (ESTADÃO, 2020b) ${ }^{63}$. No caso da Folha, durante a semana o jornal divulga os principais temas abordados pelo podcast "Café da Manhã", cuja transmissão é feita exclusivamente na plataforma Spotify, indicando uma possível parceria comercial que não chega a ser clara ${ }^{64}$, já que vemos apenas o logotipo do Spotify no story, mas nenhuma menção a uma produção de conteúdo patrocinado. O conteúdo, entretanto, pode ser acessado por não-assinantes da plataforma de streaming.

63 "O E-Investidor é um produto do Grupo Estado, com patrocínio da Ágora Investimentos, sobre finanças pessoais e investimentos voltado para pessoa física. O conteúdo entregue em diferentes plataformas é produzido por uma equipe exclusivamente dedicada ao projeto" (ESTADÃO, 2020b, online).

64 "Disponibilizado apenas no Spotify, Café da Manhã terá uma edição a cada dia, liberada sempre as 6h." (MEIO\&MENSAGEM, 2019) 
Hipótese (g): Mesmo em um contexto de grande circulação de fotos, de memes e de reproduções de vídeos, o jornalismo dá crédito para os autores ou indica a origem das imagens (indicadores F/E 14 e 15).

As duas empresas apresentam lacunas com relação à autoria de imagens utilizadas nos stories. A Folha faz referência aos autores de material fotojornalístico no último story de suas publicações diárias. No entanto, imagens reproduzidas de terceiros não levaram crédito. Já no caso do Estadão, praticamente nenhuma imagem apresenta créditos ou a fonte de onde foi extraída. Apenas três stories indicaram o origem do material audiovisual, sendo todos reproduções de trechos de séries da empresa Netflix.

Hipótese (h): As empresas concentram a publicação dos stories em um horário específico (indicadores F/E 39 e 40).

Percebemos a recorrência de publicação em certos períodos do dia nos dois jornais. De segunda à sexta, o Estadão não fez postagens no período da manhã. $O$ horário preferido do jornal foi o da tarde (12h às $18 \mathrm{~h}$ ), que contou com $67 \%$ dos stories, principalmente após as $15 \mathrm{~h}$. Os outros $44 \%$ foram ao ar à noite.

No caso da Folha, predominaram as postagens no período da noite por ser esse o horário do giro de notícias "Não durma sem saber", publicado diariamente. No total, $65 \%$ dos stories foram ao ar após as $18 \mathrm{~h}$. Em segundo lugar, o período da manhã ficou com $21 \%$ das publicações, principalmente com stories sobre o podcast "Café da Manhã".

Hipótese (i): As possibilidades de interação com a audiência nos stories são pouco exploradas pelos jornais (indicadores F/E 21, 22, 23, 29, 35, 36, 37, 38).

Nessa hipótese, é necessário fazer algumas considerações antes de dar uma resposta afirmativa ou negativa. Todos os stories publicados, pelos dois jornais, apresentavam o botão de compartilhamento (ícone de avião no canto inferior direito da tela). Como essa ferramenta aparece em todos as postagens, assumimos que essa função não deveria fazer parte das estatísticas para medição de interatividade da nossa amostra.

Temos, também, a predominância de postagens com links, em mais de $90 \%$ dos stories de ambas as empresas. É possível considerar essa uma ferramenta de 
interatividade por ser uma função do Instagram do estilo "call to action" (CTA) ${ }^{65}$, na qual o usuário pode tomar uma decisão sobre acessar ou não o site externo indicado. Mas, como essas duas formas de interação (compartilhamento e acesso a links) oferecem uma interatividade limitada, decidimos investigar a ocorrência de outras formas de interação mais dialógicas e descobrimos que as duas empresas utilizam poucos recursos que estabelecem de fato uma conversa ou conexão mais aprofundada com o leitor.

A função interativa que mais aparece é a de mensagens diretas (também conhecida como DM, do inglês, direct messages). A Folha usou a caixa para DM em $6,6 \%$ de suas postagens. Já o Estadão, em 3\%. Outra opção de interação é a partir de etiquetas de enquetes e de perguntas de múltipla escolha ou abertas.

A Folha utilizou a função uma vez, em um story de divulgação da coleção de livros no domingo. Já o Estadão utilizou, durante a semana, a caixa de perguntas em duas ocasiões e realizou uma enquete.

Outro recurso apresentado foi um story com etiqueta de contagem regressiva, usada para lembrar o usuário de um evento da marca. Além dessas ocorrências, outras dez completam a interatividade do jornal: cinco stories com etiqueta de geolocalização, três com etiqueta de hashtag e dois com etiqueta de música (nenhuma dessas utilizadas pela Folha).

Portanto, descartando as funções de compartilhamento e links, a Folha apresentou 7\% de stories com outros tipos de interação e o Estadão 14\%. Podemos dizer, com isso, que as duas empresas exploram pouco as possibilidades de interação disponibilizadas pelo Instagram para se relacionar com o usuário.

\subsection{2 - AS CATEGORIAS DE ELEMENTOS NA ESTRUTURA DOS STORIES}

Chegamos, neste tópico, ao momento de classificar os elementos do nosso conjunto por meio da categorização. Bardin define categorias como

[...] rubricas ou classes, as quais reúnem um grupo de elementos (unidades de registro, no caso da análise de conteúdo) sob um título genérico, agrupamento esse efetuado em razão das características comuns destes elementos (BARDIN, 2016, p. 147).

65 Call-to-action (CTA) é uma ferramenta de marketing que pode ser traduzida como "chamada para ação", um convite para que o usuário atue de uma determinada maneira, em geral, para acessar links. 
Quadro 2.1 - Objetivos de cada campo de análise para o estudo de stories, definidos a partir das unidades de contexto, e sua aplicação a partir de perguntas-chave

\begin{tabular}{|l|l|l|}
\hline $\begin{array}{c}\text { Campos para } \\
\text { análise de stories }\end{array}$ & \multicolumn{1}{|c|}{$\begin{array}{c}\text { Pergunta- } \\
\text { chave }\end{array}$} & \multicolumn{1}{c|}{ Objetivos } \\
\hline Temporalidade & $\begin{array}{l}\text { Quando o story } \\
\text { foi ao ar? }\end{array}$ & $\begin{array}{l}\text { Verificar o período do dia em que o story foi } \\
\text { publicado e se ele possui características de breaking } \\
\text { news }\end{array}$ \\
\hline Temática & $\begin{array}{l}\text { O que é } \\
\text { mostrado no } \\
\text { story? }\end{array}$ & $\begin{array}{l}\text { Fazer uma breve descrição da imagem para localizar } \\
\text { a temática central, principais palavras-chave do } \\
\text { texto, elementos humanos e emocionais (gifs ou } \\
\text { emojis) }\end{array}$ \\
\hline Referência & $\begin{array}{l}\text { De onde vem o } \\
\text { conteúdo do } \\
\text { story? }\end{array}$ & $\begin{array}{l}\text { Identificar se o layout do story é personalizado ou se } \\
\text { é semelhante ao estilo de edição nativa do } \\
\text { Instagram. Localizar créditos de imagens ou textos e } \\
\text { da produção dos stories. Observar o tipo de imagem } \\
\text { e sua possível origem (jornalística ou reproduzida a } \\
\text { partir de terceiros) e verificar se o texto do story é } \\
\text { semelhante ao texto do site para onde o link leva. }\end{array}$ \\
\hline Formato & $\begin{array}{l}\text { Como é } \\
\text { configurado o } \\
\text { story? }\end{array}$ & $\begin{array}{l}\text { Observar o estilo das imagens utilizadas (se são } \\
\text { predominantemente verticais ou horizontais, se } \\
\text { possuem filtro fotográfico, se são estáticas ou com } \\
\text { movimento). Avaliar se há texto e/ou áudio, a } \\
\text { quantidade de palavras e a presença de um } \\
\text { jornalista selfie. }\end{array}$ \\
\hline Finalidade & $\begin{array}{l}\text { Quem conversa } \\
\text { no story? }\end{array}$ & $\begin{array}{l}\text { Para onde o } \\
\text { story direciona? } \\
\text { etiquetas de Localização, de Hashtag, de Música, de } \\
\text { Pergunta etc. Verificar se o story permite o envio de } \\
\text { mensagens diretas (DM). }\end{array}$ \\
\hline foi feito?
\end{tabular}

Fonte: elaborado pela autora (2020).

Para Bardin (2016), a análise de conteúdo se fundamenta na articulação entre a superfície dos textos (o que pode ser descrito) e os fatores que tenham determinado essas ocorrências (o que pode ser obtido a partir da dedução lógica). Reconhecemos, com isso, a necessidade de uma leitura dos dados obtidos no processo de descrição para entender o que eles podem dizer sobre o contexto de produção da mídia analisada e, assim, partir para a identificação das categorias. O objetivo de analisar o 
conteúdo, muito mais do que obter uma fotografia que revele o evento, é encontrar padrões capazes de oferecer respostas a situações correlatas.

Após a leitura dos dados numéricos, dos gráficos e da rotina de publicação de cada empresa no espaço dos stories, reorganizamos as unidades de registro em novas "caixas", isto é, em áreas mais amplas segundo a sua função dentro da publicação.

Os aspectos identificados estão mais ligados ao empreendimento jornalístico nos Stories como um todo e não apenas aos jornais aqui analisados. Diferentemente das unidades de contexto (quadro 2.1), que contribuíram para a organização dos dados durante a coleta, esses novos grupos se relacionam às práticas encontradas tanto no perfil do Estadão, quanto no perfil da Folha.

Como elementos fundamentais para a sua construção, reconhecemos que esses cinco pilares se mostram essenciais para se pensar a estrutura dos stories. Juntos, caracterizam funções-chave no formato e podem ser avaliados pelo emissor da mensagem durante a formulação de estratégias para as publicações.

Assim, as unidades de registro foram redistribuídas nas seguintes categorias: elementos narrativos, elementos visuais, elementos interativos, elementos jornalísticos e elementos comerciais.

a) Elementos narrativos (quadro 2.2): os stories são um ambiente construído em sua essência para contar histórias. A forma de narrar, os ganchos entre os stories e demais aspectos narrativos são levados em conta no planejamento de publicações.

Quadro 2.2 - Elementos narrativos

\begin{tabular}{|l|l|}
\hline F/E-01 Breve descrição da imagem & F/E-24 Presença de texto \\
\hline $\begin{array}{l}\text { F/E-02 Layout personalizado com } \\
\text { design pré-produzido }\end{array}$ & F/E-25 Quantidade de palavras \\
\hline $\begin{array}{l}\text { F/E-03 Layout semelhante ao } \\
\text { nativo do Instagram }\end{array}$ & F/E-27 Palavras-chave \\
\hline F/E-20 Adesivo (gif ou emoji) & F/E-28 Presença de áudio \\
\hline
\end{tabular}

Fonte: Elaborado pela autora (2020) 
b) Elementos visuais (quadro 2.3): nesta categoria se enquadram os aspectos visuais do story e os tipos de imagem escolhidos para compor a publicação.

Quadro 2.3 - Elementos visuais

\begin{tabular}{|l|l|}
\hline F/E-04 Imagem vertical (full screen) & F/E-08 Imagem com movimento \\
\hline $\begin{array}{l}\text { F/E-05 Imagem predominantemente } \\
\text { horizontal }\end{array}$ & F/E-09 Presença humana na imagem \\
\hline F/E-06 Imagem com filtro & F/E-16 Jornalista Selfie \\
\hline F/E-07 Imagem estática & $\begin{array}{l}\text { F/E-19 Não é possível identificar origem da } \\
\text { imagem (uso intenso de filtro) }\end{array}$ \\
\hline
\end{tabular}

Fonte: elaborado pela autora (2020)

c) Elementos interativos (quadro 2.4): essa categoria agrega todos os itens que de alguma forma estabelecem uma relação dialógica com a audiência ou que solicitam uma ação do usuário. Por meio da interatividade, o perfil da empresa jornalística pode estabelecer uma conversa com o público e também fortalecer a relação das pessoas com a marca através do engajamento na plataforma.

Quadro 2.4 - Elementos interativos

\begin{tabular}{|l|l|}
\hline F/E-21 Etiqueta de Localização & F/E-35 Repost \\
\hline F/E-22 Etiqueta de Hashtag & F/E-36 Etiqueta de pergunta \\
\hline F/E-23 Etiqueta de Música & F/E-37 Etiqueta de menção \\
\hline F/E-29 Link & F/E-38 Permite mensagens diretas (DM) \\
\hline
\end{tabular}

Fonte: elaborado pela autora (2020)

d) Elementos jornalísticos (quadro 2.5): Os stories aparecem como mais um meio para distribuir notícias e demais conteúdos editoriais. O texto jornalístico, assim como em outras mídias, apresenta especificidades que o diferencia do texto publicitário. Apesar de as fronteiras entre um e outro estarem cada vez menos visíveis, aspectos do gênero jornalístico encontram espaço para serem trabalhados, como identificado nos indicadores dessa categoria. 
Quadro 2.5 - Elementos jornalísticos

\begin{tabular}{|l|l|}
\hline F/E-12 Conteúdo editorial-noticioso & F/E-17 Imagem de origem jornalística \\
\hline F/E-13 Temática central & F/E-18 Imagem de terceiros reproduzida \\
\hline F/E-14 Crédito de imagens/textos & F/E-26 Texto semelhante ao site \\
\hline F/E-15 Crédito de produção dos stories & F/E-40 Características de breaking news \\
\hline
\end{tabular}

Fonte: Elaborado pela autora (2020)

e) Elementos comerciais (quadro 2.6): De maneira mais explícita (nem tanto, no caso do branded content), encontramos nos stories itens que indicam a produção de conteúdo com finalidade publicitária ou comercial, ou relacionados à estratégia de publicações, como os melhores horários do dia para publicar.

Quadro 2.6 - Elementos comerciais

\begin{tabular}{|l|l|}
\hline F/E-10 Conteúdo publicitário & F/E-32 Link para outro aplicativo \\
\hline F/E-11 Branded content & F/E-33 Link para conteúdo publicitário \\
\hline F/E-30 Link para o site com paywall & F/E-34 Link para branded content \\
\hline F/E-31 Link para o site sem paywall & F/E-39 Período do dia em que foi publicado \\
\hline
\end{tabular}

Fonte: Elaborado pela autora (2020)

No próximo capítulo, complementaremos e aprofundaremos as discussões iniciadas com as categorias aqui postas, trazendo referências teóricas e contextualizando os campos da comunicação a partir da análise das relações (BARDIN, 2016) dos elementos apresentados na prática jornalística dos dois jornais nos Stories do Instagram. 


\section{A INFLUÊNCIA DE VALORES DOS STORIES DO INSTAGRAM NOS STORIES JORNALÍSTICOS}

Fazer jornalismo hoje não é a mesma coisa que fazer jornalismo no século XIX ou no século XX. O fim do milênio trouxe muitas mudanças no cenário da comunicação e isso teve um forte impacto para o mercado de notícias. Como vimos pela trajetória do Estadão e da Folha, ambas as empresas começaram a informatizar suas redações na década de 1990, mas nem isso garantiu que as duas conseguissem acompanhar o bonde da revolução digital, visto que o modelo comercial jornalístico ainda padece com as instabilidades financeiras globais.

Por mais que nos esforcemos em seguir as novas tendências, a sensação é a de que estamos sempre um passo atrás de todas as transformações tecnológicas. Principalmente agora, quando encontramos a inteligência artificial vinculada a quase todas as áreas da sociedade. Para que o jornalismo encontre formas alternativas de romper as bolhas criadas pelos algoritmos refinados das plataformas digitais e sobreviver às suas regras, uma das opções é hackear essa corrida, ou melhor dizendo, entender os atalhos disponíveis para o ser humano se adaptar e melhorar sua relação com elas. Esses caminhos podem ser descobertos por meio do estudo aprofundado dos mecanismos presentes nas empresas de tecnologia e, inclusive, pela observação de como a própria mente humana funciona. Afinal, não entregamos notícias para máquinas, mas sim, para pessoas. As máquinas apenas transportam as informações. Entretanto, um dos principais problemas é que, no momento, são elas que estão decidindo para quem as notícias serão entregues, com critérios de seleção contaminados por vieses políticos, econômicos e sociais, criados segundo os interesses das Big Techs e de seus acionistas.

Com o propósito de auxiliar o jornalismo diante dos desafios atuais, vimos nos capítulos anteriores que os Stories são mais uma via midiática de acesso para o diálogo com a sua audiência. No segundo capítulo fizemos a análise categorial, que se baseou, principalmente, na classificação e na frequência de ocorrência de determinadas unidades definidas para o estudo dos stories. Com isso, após o agrupamento dos itens, chegamos às seguintes categorias de elementos: narrativos, visuais, interativos, jornalísticos e comerciais (quadro 3.1). 
Quadro 3.1 - Divisão em categorias dos elementos que compõem os stories jornalísticos a partir de suas funções

\begin{tabular}{|l|l|}
\hline \multicolumn{1}{|c|}{ Componentes } & \multicolumn{1}{c|}{ Funções no story } \\
\hline Elementos narrativos & Definem a forma de narrar, os ganchos entre os stories demais aspectos narrativos. \\
\hline Elementos visuais & $\begin{array}{l}\text { Constituem os aspectos visuais do story e os tipos de imagens escolhidos para a } \\
\text { composição. }\end{array}$ \\
\hline Elementos interativos & $\begin{array}{l}\text { Agrega todos os itens que de alguma forma estabelecem uma relação dialógica } \\
\text { com a audiência ou que solicitam uma ação do usuário. Fortalece a relação das } \\
\text { pessoas com a marca através do engajamento na plataforma. }\end{array}$ \\
\hline $\begin{array}{l}\text { Elementos } \\
\text { jornalísticos }\end{array}$ & $\begin{array}{l}\text { O texto jornalístico, assim como em outras mídias, apresenta especificidades que o } \\
\text { diferencia do texto publicitário. Os elementos dessa categoria caracterizam aspectos } \\
\text { do gênero jornalístico. }\end{array}$ \\
\hline Elementos comerciais & $\begin{array}{l}\text { Indicam a produção de conteúdo com finalidade publicitária e comercial, ou aspectos } \\
\text { relacionados à estratégia de marketing das publicações, como a análise dos } \\
\text { melhores dias e horários para divulgação. }\end{array}$ \\
\hline
\end{tabular}

Fonte: elaborado pela autora (2020).

Seguimos, neste terceiro capítulo, a discussão dos elementos que compõem os Stories, cujas características foram identificadas durante a etapa de categorização na análise de conteúdo (BARDIN, 2016), e que são compartilhados tanto pelo Estadão, como pela Folha.

Para complementar a categorização, Bardin (2016) relata uma série de técnicas, dentre as quais está a análise "estrutural". A autora explica que a análise de conteúdo recebeu contribuições importantes a partir da década de 1960 com as ideias dos pesquisadores estruturalistas, que tinham em mente a insuficiência que muitas vezes havia em análises com classificações simples de frequências de itens. Avaliar a estrutura, explica Bardin, significa se debruçar sobre o arranjo dos elementos, "tentando descobrir as constantes significativas nas suas relações (aparentes ou latentes) que organizam esses itens entre si” (2016, p. 267).

Bardin ressalta a importância da noção de sistema para avaliar as estruturas, pois a modificação de um ou mais mecanismos pode interferir em toda a cadeia de elementos interligados. Nessa abordagem, consonante com o conceito de ecossistema de mídias compartilhado pela sociedade, é possível formar modelos operatórios, ampliando o campo de visão das especificidades que os compõem.

Este termo de "análise estrutural" engloba um número de técnicas que tentam passar do nível atômico da análise a um nível molecular, e central os seus procedimentos, mesmo num plano muito elementar, mais nos laços que unem os componentes do discurso, do que nos próprios componentes. (BARDIN, 2016, p. 268). 
Sem a pretensão de fazer uma análise estrutural totalizante e universal, por conta da limitação do corpus da nossa amostra, decidimos destacar o campo jornalístico dentre as categorias identificadas e trabalhar na contextualização dos demais elementos observando o presente cenário da atividade via Instagram Stories. Demos a esse grupo a denominação "stories jornalísticos" e reagrupamos ao seu redor as outras categorias após as nossas leituras sistematizadas da coleta.

Com os dados obtidos, elaboramos um modelo gráfico (figura 3.1) para facilitar a visualização dos campos que influenciam a atuação das empresas de jornalismo dentro dos Stories no Instagram. Baseado em um diagrama de Venn (MARTINS, 2014), os stories jornalísticos aparecem ao centro. Organizamos as informações em conjuntos circulares com as possíveis relações e intersecções entre um ou mais elementos, localizando cada um deles dentro do universo da plataforma - indicado pelo retângulo -, que no nosso caso é o Instagram.

Figura 3.1 - Representação dos valores estruturantes dos stories jornalísticos

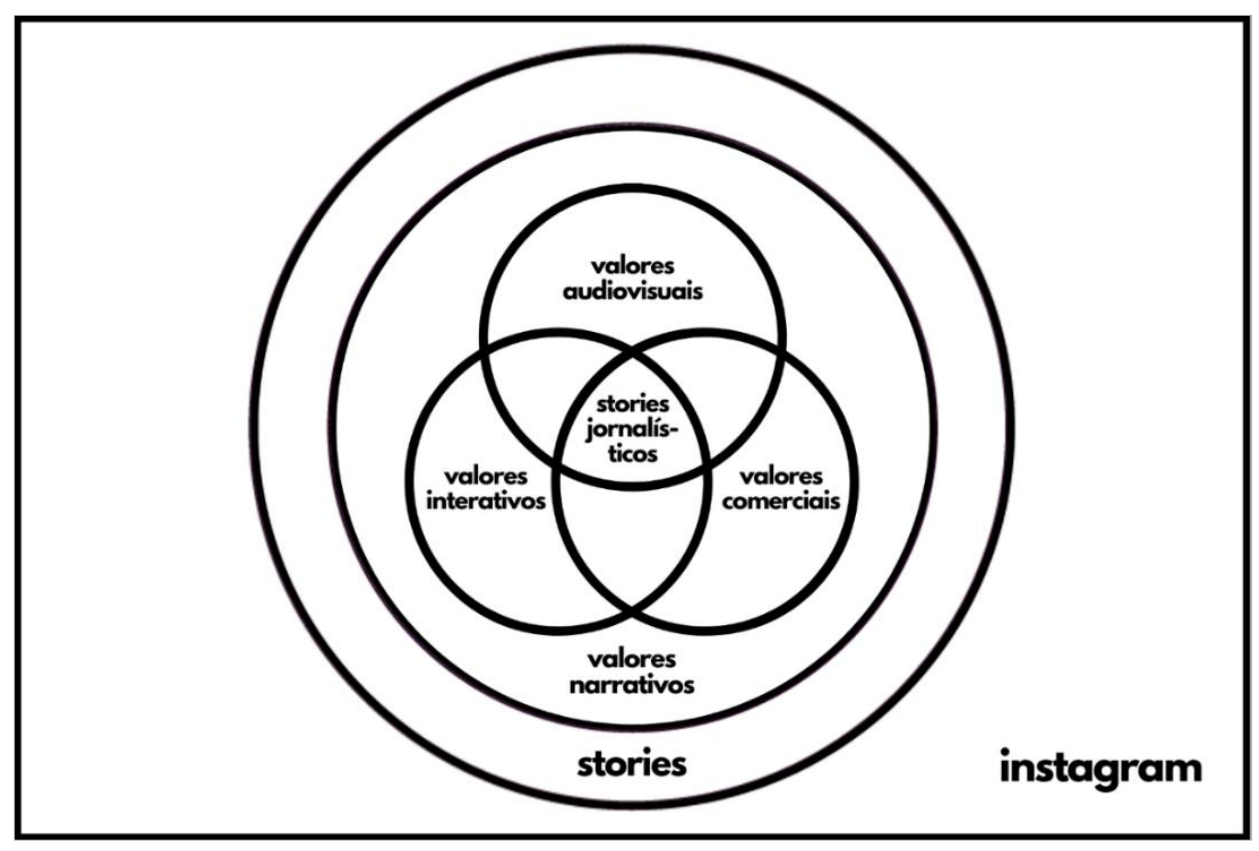

Fonte: elaborado pela autora (2020)

Percebemos, como pode ser visto no diagrama, que os stories jornalísticos são influenciados simultaneamente por valores audiovisuais, comerciais e interativos dentro da lógica de funcionamento da plataforma Instagram, a partir de valores narrativos próprios da construção do formato de apresentação de mídias dos Stories (quadro 3.2). Decidimos utilizar a nomenclatura "valores" por uma proximidade com a noção de valor-notícia, componente da noticiabilidade que é definido por Wolf (2006) 
como sendo o conjunto de critérios de relevância utilizados na seleção de notícias, presentes em todo o processo de produção jornalístico, e que servem de guias para selecionar os acontecimentos que serão trabalhados pelo jornalistas.

Assim como a definição de Wolf (2006), que afirma que os valores-notícia funcionam de maneira complementar uns aos outros, os valores aqui apresentados também se articulam de maneira similar, guiando a estruturação do conteúdo nos Stories das empresas jornalísticas.

Quadro 3.2 - Valores dos Stories do Instagram, suas características e suas influências sobre os stories jornalísticos

\begin{tabular}{|c|c|c|}
\hline $\begin{array}{l}\text { Valores dos } \\
\text { Stories }\end{array}$ & Características & Tipos de influência \\
\hline $\begin{array}{l}\text { Valores } \\
\text { interativos }\end{array}$ & $\begin{array}{l}\text { A partir do uso de elementos interativos nos } \\
\text { stories, esses parâmetros abrem espaço para } \\
\text { os leitores serem ouvidos e participarem do } \\
\text { jornal e, também, transitar entre outras } \\
\text { publicações e perfis da plataforma. }\end{array}$ & $\begin{array}{l}\text { Influenciam o engajamento dos } \\
\text { seguidores com a marca. Quanto mais } \\
\text { uma pessoa interage com um perfil no } \\
\text { Instagram, maior a chance de o } \\
\text { conteúdo produzido por essa conta ser } \\
\text { entregue novamente para essa mesma } \\
\text { pessoa e para outras, de forma } \\
\text { orgânica. }\end{array}$ \\
\hline $\begin{array}{l}\text { Valores } \\
\text { comerciais }\end{array}$ & $\begin{array}{l}\text { A presença de ferramentas como as } \\
\text { parcerias pagas integradas à plataforma } \\
\text { permite ações de marketing direto. A } \\
\text { monetização pode ser potencializada de } \\
\text { acordo com o objetivo e metas do } \\
\text { anunciante. }\end{array}$ & $\begin{array}{l}\text { Oferecem fontes de renda alternativas } \\
\text { para as empresas a partir de novas } \\
\text { estratégias de publicidade. Tornam as } \\
\text { fronteiras entre informação jornalística e } \\
\text { publicidade cada vez mais indefinidas, } \\
\text { principalmente com o uso de branded } \\
\text { content e de branded entertainment. }\end{array}$ \\
\hline $\begin{array}{l}\text { Valores } \\
\text { audiovisuais }\end{array}$ & $\begin{array}{l}\text { Uso de recursos visuais como filtros de } \\
\text { realidade aumentada, de conteúdos voltados } \\
\text { para o entretenimento e o infotenimento. } \\
\text { Mescla de formatos diferentes, apelos } \\
\text { emocionais e assuntos mais leves. } \\
\text { Valorização da cultura dos fãs, com a } \\
\text { exploração de assuntos relacionados à } \\
\text { nichos específicos. }\end{array}$ & $\begin{array}{l}\text { Oferecem caminhos para a expressão } \\
\text { de novas formas de visibilidade nas } \\
\text { redes. Aumentam o acesso à intimidade } \\
\text { dos profissionais da imprensa e } \\
\text { potencializa a sua atuação como } \\
\text { influenciadores digitais. Estimulam o } \\
\text { envolvimento do público e a } \\
\text { identificação das pessoas com a marca. }\end{array}$ \\
\hline $\begin{array}{l}\text { Valores } \\
\text { narrativos }\end{array}$ & $\begin{array}{l}\text { Os Stories possuem potencial para uso de } \\
\text { técnicas de arte sequencial, que podem ser } \\
\text { apropriadas das histórias em quadrinhos } \\
\text { (HQs), cinema e televisão. Os Stories } \\
\text { também permitem a construção de histórias } \\
\text { seguindo padrões narrativos, muito utilizados } \\
\text { pelo teatro e pela literatura, como o arco } \\
\text { narrativo. As histórias podem ser construídas } \\
\text { a partir de ferramentas pré-programadas de } \\
\text { design presentes na plataforma. }\end{array}$ & $\begin{array}{l}\text { A apropriação de técnicas narrativas } \\
\text { favorece e intensifica a sensação de } \\
\text { imersão nas histórias retratadas e } \\
\text { potencializa o interesse das pessoas } \\
\text { pelas publicações. O uso de ferramentas } \\
\text { de design simplificadas mobiliza as } \\
\text { emoções das pessoas e contribui para o } \\
\text { sucesso do processo de comunicação. }\end{array}$ \\
\hline
\end{tabular}

Fonte: elaborado pela autora (2020).

Nos próximos quatro tópicos do capítulo, aprofundaremos as discussões dos valores que influenciam o relacionamento entre plataformas, empresas de jornalismo e audiência, apresentando em cada um exemplos dos Stories do Estadão e da Folha. 


\title{
3.1 VALORES INTERATIVOS: O DIÁLOGO ENTRE AUDIÊNCIA E JORNAIS
}

O Instagram pode ter nascido como um aplicativo móvel para amantes de fotografia, mas hoje ele vai bem além disso, principalmente quando estamos falando de interatividade ${ }^{66}$. Como plataforma, ele congrega diversos tipos de mídia e de possibilidades de troca de informação entre os seus usuários, muitos deles úteis para a atuação jornalística.

Os Stories do Instagram foram criados após a plataforma já adotar algoritmos personalizados para apresentar as publicações aos usuários. Até 2016, todos as postagens ainda eram mostradas cronologicamente, diretamente no feed das pessoas (anteriormente conhecido como timeline, justificando o uso do termo linha do tempo em inglês). Apesar de não haver uma explicação detalhada do Instagram sobre as regras que definem esses algoritmos, sabemos que três categorias principais podem influenciar a ordem e a prioridade de conteúdos apresentados aos usuários: o interesse percebido pelo Instagram do quanto o usuário gostaria de ver aquela postagem, baseado em consumo de conteúdo similar; a atualidade da postagem, pois quanto mais recente, mais relevante se torna para a plataforma; e o relacionamento do usuário com o perfil que postou o conteúdo, que é determinado por uma gama de fatores, dentre os quais estão a frequência de curtidas, comentários e compartilhamentos do usuário com o perfil (LEAVER; HIGHFIELD; ABIDIN, 2020). Essa conduta é um típico exemplo do processo de dataficação da sociedade (VAN DIJCK; POELL; WALL, 2018).

\begin{abstract}
Mais especificamente no que diz respeito às plataformas online, todas as formas de interação do usuário podem ser capturadas como dados: classificações, pagamentos, inscrições, visualizações, relacionamentos e buscas, mas também amizades, interesses, curtidas, postagens, comentários e compartilhamentos. Nos primeiros estudos, esses dados eram frequentemente considerados um subproduto das plataformas online; à medida que as plataformas amadureciam, as empresas de tecnologia gradualmente se transformavam em empresas de dados, transformando dados em fontes de recursos primários. A dataficação confere às plataformas o potencial de desenvolver técnicas de análise preditiva e em tempo real, que são vitais para o fornecimento de publicidade direcionada e serviços em uma
\end{abstract}

66 A interatividade sempre existiu entre as pessoas e os meios de comunicação, mas em níveis diferentes. A partir da inserção das tecnologias digitais, as possibilidades de interação se ampliaram consideravelmente, ganhando destaque na relação entre o emissor-meio-receptor. No presente trabalho usaremos a explicação dada por Rost (2014) para o conceito de interatividade, que o define como "a capacidade gradual que um meio de comunicação tem para dar maior poder aos utilizadores" (ROST, 2014, p. 55). Esse potencial pode ser exercido tanto na seleção de conteúdos ("interatividade seletiva") como nas condições de expressão e comunicação ("interatividade comunicativa"). 
ampla variedade de setores econômicos. (VAN DIJCK; POELL; WALL, 2018, p. 33, tradução nossa $)^{67}$.

Ou seja, quanto mais uma pessoa interage com um perfil no Instagram, maior a chance de o conteúdo produzido por essa conta ser entregue novamente para essa mesma pessoa e para outras, de forma orgânica ${ }^{68}$. Portanto, além de abrir espaço para os leitores serem ouvidos e participarem do jornal, os elementos de interatividade nos Stories também são essenciais para as empresas jornalísticas sobreviverem frente ao jogo imposto pelos algoritmos, já que são eles os responsáveis por definirem as publicações apresentadas com mais frequência aos usuários em sua navegação no Instagram.

\subsubsection{AS FERRAMENTAS DE INTERAÇÃO DENTRO DOS STORIES}

Os smartphones guardam muitas similaridades com os avanços trazidos pela introdução do controle remoto para a televisão e a prática do zapping, definida por Machado (1985) como a "a mania de mudar de canal a qualquer pretexto, na menor queda de ritmo ou de interesse do programa e, sobretudo, quando entram os comerciais" (MACHADO, 1985. p. 113). Jenkins (2009) relata que, com frequência, a indústria de mídia classifica os consumidores televisivos a partir de categorias, segundo a sua relação com a programação televisiva: zapeadores, casuais e fiéis.

Fiéis assumem compromissos de longo prazo; zapeadores são como
pessoas que, nas festas, estão sempre olhando para trás, para ver se alguém
mais interessante acabou de chegar. Os casuais estão em algum ponto entre
os fiéis e os zapeadores; assistem a uma determinada série quando se
lembram dela ou quando não têm nada melhor para fazer. Geralmente
assistem do começo ao fim, mas são mais propensos a abandonar o
programa se começarem a ficar entediados. [...] Nenhum espectador é
exclusivamente fiel, casual ou zapeadores; [...] ninguém sabe ao certo, ainda,
se o novo ambiente de mídia produziu mais zapeadores, casuais ou fiéis.
(JENKINS, 2009, p. 111-112)

67 No original: "More specifically with regard to online platforms, every form of user interaction can be captured as data: rating, paying, enrolling, watching, dating, and searching but also friending, following, liking, posting, commenting, and retweeting. In early studies, such data were often considered a byproduct of online platforms; as platforms matured, technology companies gradually transformed into data firms, turning data into prime resources. Datafication endows platforms with the potential to develop techniques for predictive and real- time analytics, which are vital for delivering targeted advertising and services in a wide variety of economic sectors".

${ }^{68}$ No mundo do marketing e das redes sociais, orgânico diz respeito ao conteúdo de uma marca que chega ao usuário sem o artifício do impulsionamento pago, de maneira natural ou voluntária. 
Além da cultura do zapping herdada graças à televisão, outros elementos interferem na relação entre usuário e conteúdo, dentre eles, o fato de o smartphone fundir, em apenas um dispositivo, o controle e a tela por meio de sua configuração sensível ao toque. Como a tela está próxima ao corpo do usuário, o aspecto remoto se dilui, tornando-se presente o caráter instantâneo do toque dos dedos à tela na navegação entre hiperlinks. Com a introdução de dispositivos móveis sensíveis ao toque, Palacios e Cunha (2012) acrescentam a tactilidade ${ }^{69}$ como um elemento fundamental na relação entre usuários e empresas jornalísticas que atuam na Internet.

Dentro do ambiente dos Stories, os gestos tornam a experiência de trocar de canal incrivelmente sutil: um toque na lateral direita faz avançar um story, já na lateral esquerda, faz retroceder um story; deslizar para a esquerda avança para os stories do próximo perfil, e, para lateral direita, volta para o último perfil visto; deslizar para cima acessa um link externo e deslizar para baixo fecha a janela de stories. Tal qual em um passe de mágica, o usuário tem, na palma da mão e na ponta dos dedos, a possibilidade de praticar o zapping de maneira muito mais fluída e ágil. Isso coloca uma intensa pressão em quem produz conteúdo, uma vez que é necessário ser cada vez mais criativo e continuar dando razões suficientes para o usuário permanecer engajado à marca e interessado em consumir seus stories.

Na classificação mostrada por Jenkins (2009), percebe-se que usuários fiéis são muito mais valiosos do que os zapeadores, do ponto de vista comercial, de acordo com um estudo conduzido pela Initiative Media. A probabilidade de os fiéis prestarem atenção aos anúncios é duas vezes maior, e a de se lembrarem de categorias de produtos é duas ou três vezes maior do que a de espectadores casuais e, "à medida que a pesquisa impacta as decisões de programação, a indústria midiática tenta gerar conteúdos que atraiam fiéis, que diminuam a velocidade dos zapeadores e que transformem casuais em fãs" (JENKINS, 2009, p. 115).

Esses dados demonstram a importância de conquistar e, mais do que isso, fidelizar o público que transita pelos Stories. Dentre as opções de interatividade com a audiência (figura 3.2) disponibilizadas pela própria plataforma, o Estadão e a Folha deram prioridade a alguns recursos durante a semana de stories analisados.

69 "Vários termos são utilizados para descrever aquilo que pode ser sentido por meio do tato, como tateabilidade, tatibilidade e tatilidade. Optamos pela utilização da palavra tactilidade, por se aproximar do termo inglês tactility e do latim tactilis, que descrevem algo tangível, sentido pelo toque." (PALACIOS; CUNHA, 2012, p. 669) 
Figura 3.2 - Exemplo de etiquetas de interação disponíveis para personalização dos stories

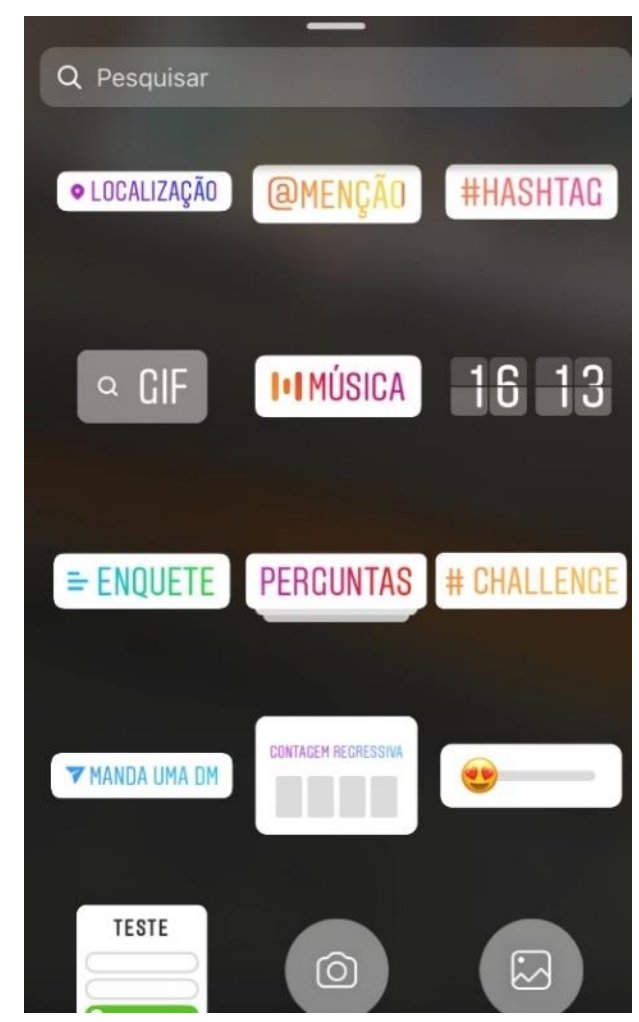

Fonte: captura de tela feita pela autora (2020)/ Reprodução Instagram

Além dos recurso de compartilhamento e de links externos, as interações mais utilizadas foram as etiquetas de (a) enquete, (b) perguntas, (c) contagem regressiva e de (d) mensagem direta (DM).

$\mathrm{Na}$ sequência, apresentaremos exemplos de como esses elementos foram utilizados:

a) Perguntas: oferece uma caixa de texto (figura 3.3), na qual é possível fazer uma pergunta ou outro tipo de solicitação aos usuários. As respostas recolhidas ficam armazenadas de forma privada no perfil do jornal. Na figura 3.4, o Estadão publicou no dia seguinte uma seleção de respostas enviadas pelos leitores. 
Figuras 3.3 e 3.4- Uso do recurso Perguntas para interação com a audiência

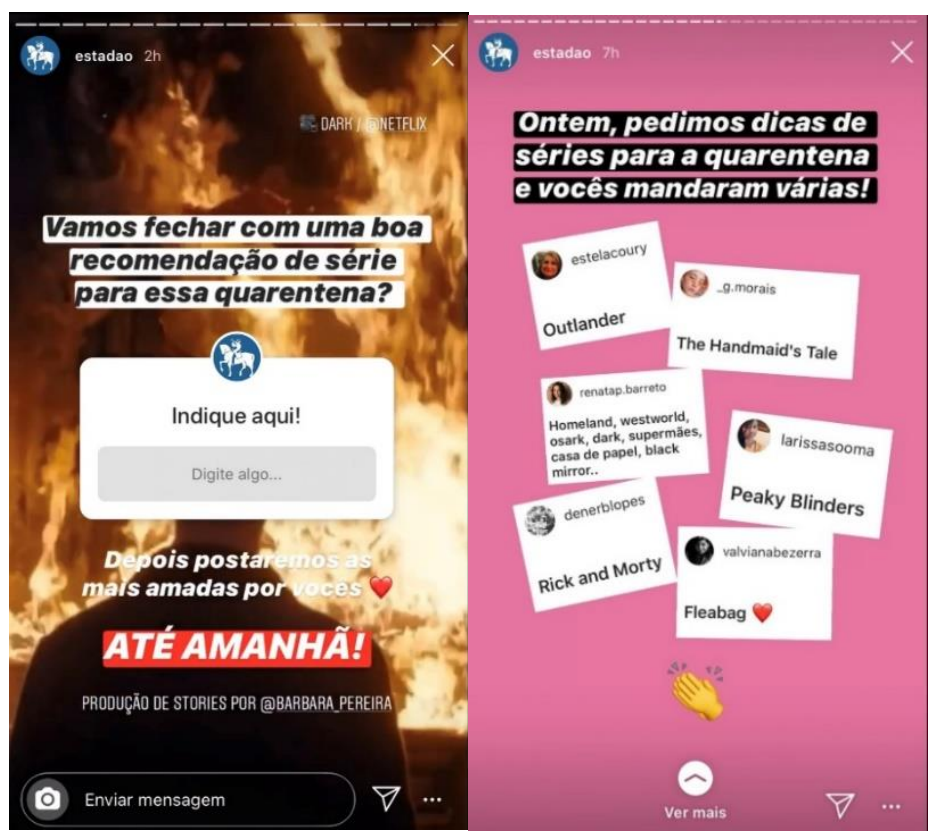

Fonte: captura de tela feita pela autora (2020)/ Reprodução Instagram

b) Enquete: a Folha utilizou uma enquete para engajar os leitores na divulgação de uma coleção de livros (figura 3.5). A plataforma, por meio dessa função, oferece a opção de interação do tipo "ou isso ou aquilo". Permite apenas duas opções de resposta (figura 3.6) e apresenta automaticamente o resultado geral logo depois que o usuário faz a sua escolha (figura 3.7).

Figuras 3.5 a 3.7- Uso da Enquete para interação com a audiência

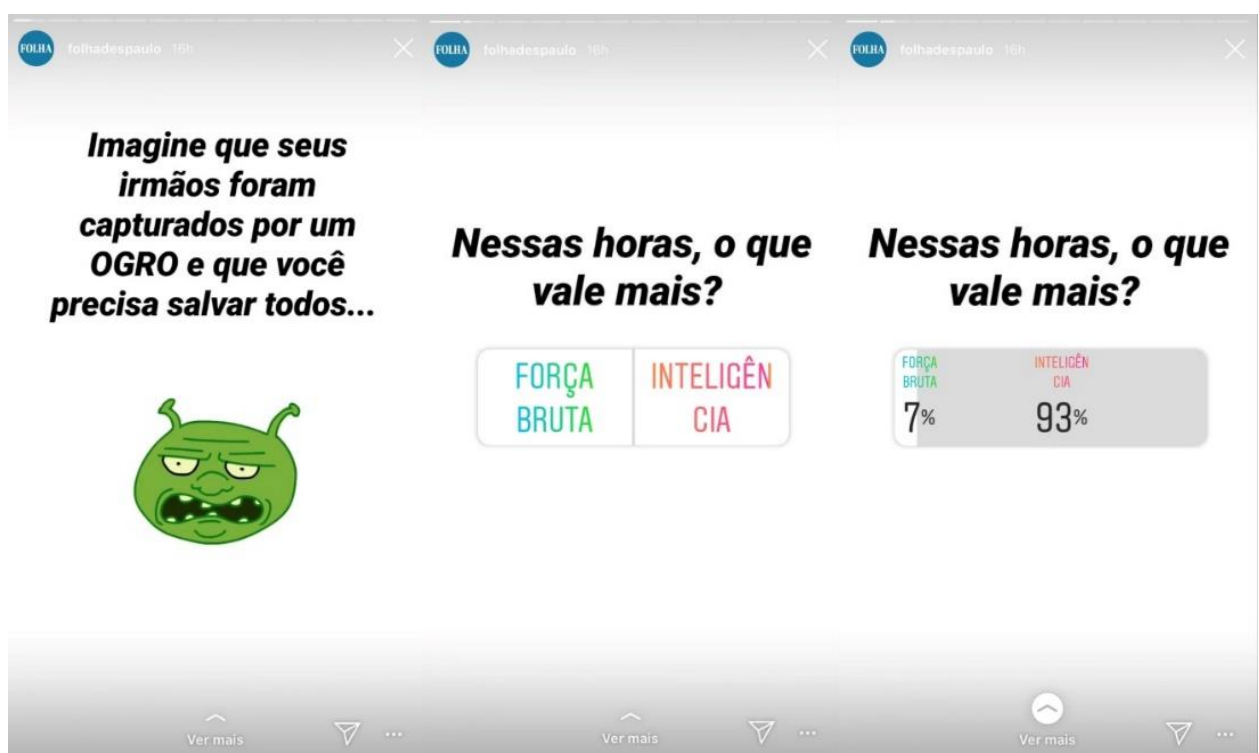

Fonte: captura de tela feita pela autora (2020)/ Reprodução Instagram 
c) Contagem regressiva: A ferramenta permite que o usuário receba uma notificação no smartphone quando a contagem regressiva (figura 3.8) termina para lembrá-lo de um evento. Ao clicar na etiqueta (figura 3.9), o usuário recebe um aviso informando que o dono do perfil, no caso, o Estadão, poderá ver que a pessoa ativou o lembrete. Uma mensagem de confirmação aparece após clicar no botão com o sino (figura 3.10).

Figuras 3.8 a 3.10- Uso da Contagem Regressiva para interação com a audiência

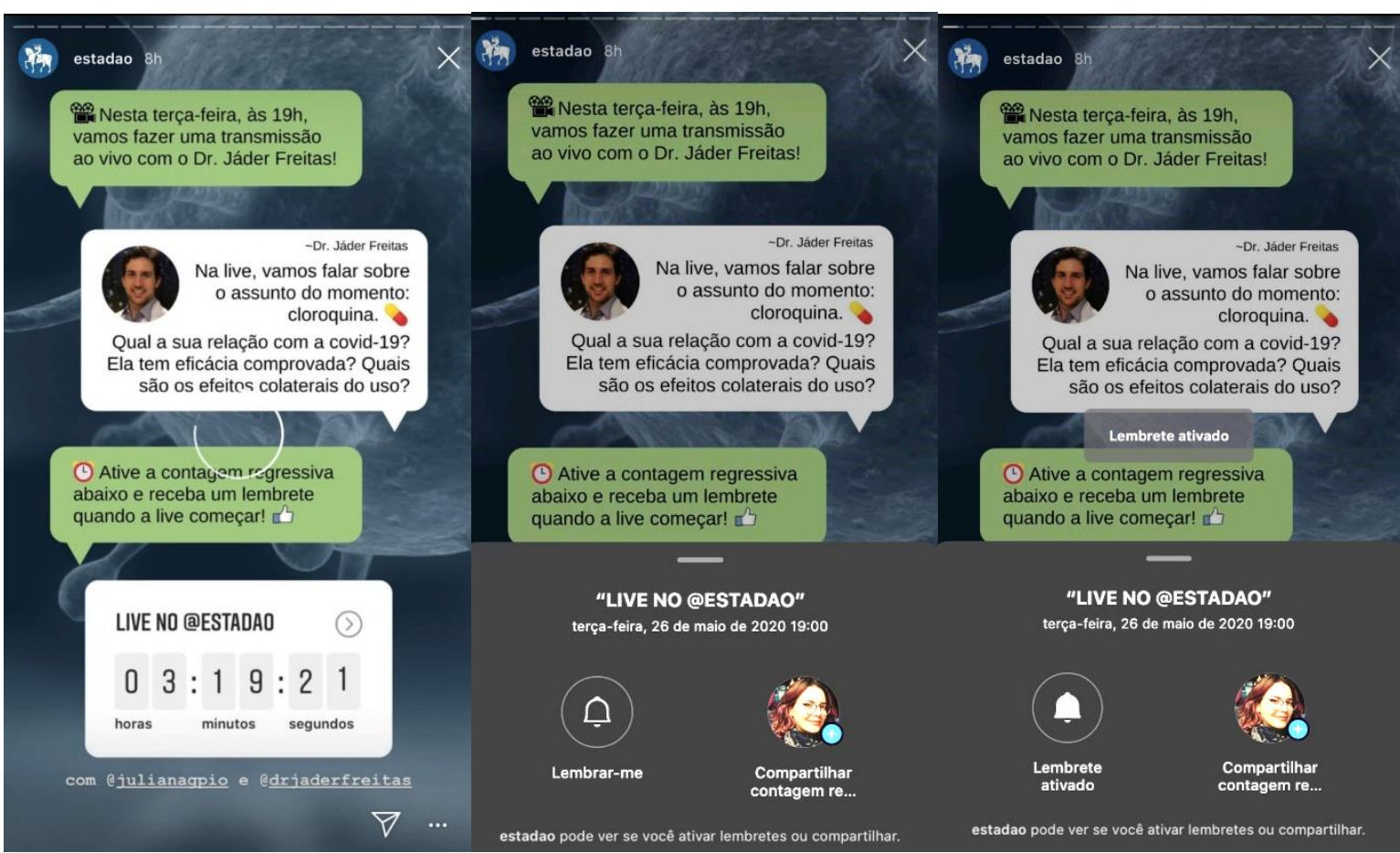

Fonte: captura de tela feita pela autora (2020)/ Reprodução Instagram

d) Mensagem direta (DM): Por esse espaço, os usuários podem enviar comentários e sugestões, de maneira privada. A empresa tem acesso às mensagens, podendo estabelecer um diálogo com o remetente. No exemplo, o perfil da Folha deixou a opção de envio de mensagens diretas aberta ao público na primeira (figura 3.11) e na última (figura 3.12) postagem do Não Durma Sem Saber, na parte inferior dos stories. Além dessa opção nativa de DM nos stories, também é possível usar uma etiqueta para essa mesma função. 


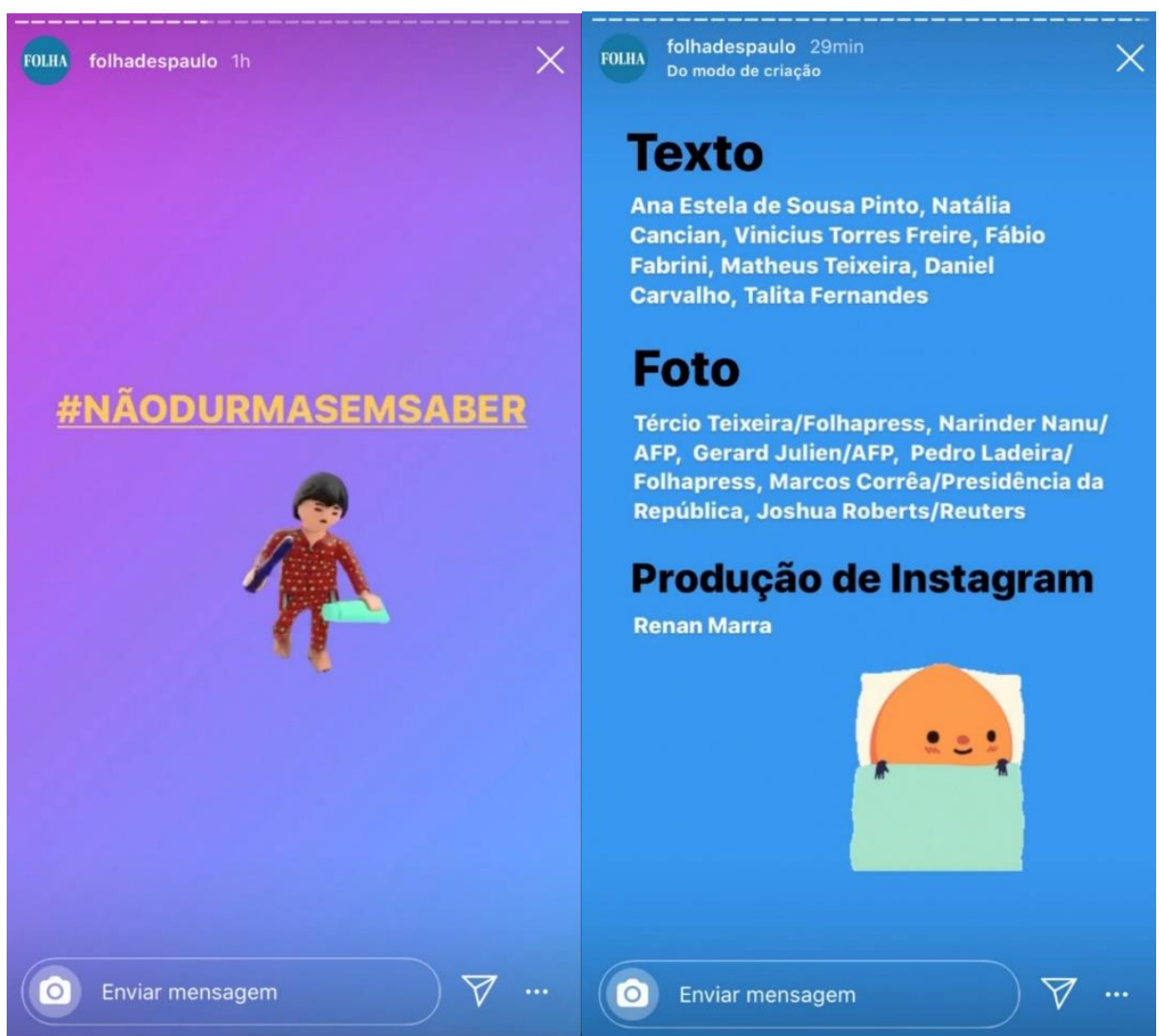

Fonte: captura de tela feita pela autora (2020)/ Reprodução Instagram

Outras ferramentas de interação disponíveis são as etiquetas de teste e de escala de intensidade com emoji, que não foram utilizadas na semana de coleta. A primeira permite fazer perguntas de múltipla escolha com a resposta dada imediatamente e, a segunda, oferece uma escala de intensidade com espaço para texto e com a possibilidade de personalizar o emoji utilizado. No próximo tópico abordaremos as etiquetas de Localização e Hashtag.

\subsubsection{O USO DE ETIQUETAS DE METADADOS NO INSTAGRAM}

Apesar de reconhecer os avanços da participação do público na rotina de produção das notícias, Rost (2014, p. 55) acredita que a cultura da participação ainda está distante de uma "horizontalidade total" entre usuários e os meios de comunicação ou os seus jornalistas. Há de se reconhecer, no entanto, que nos últimos anos os leitores tiveram uma amplificação de suas vozes, principalmente nos ambientes de redes sociais online. Rost (2014) afirma que essa maior visibilidade modifica todo o 
ecossistema de mídias, principalmente porque os veículos jornalísticos pautam os assuntos mais comentados na Internet, produzindo notícias sobre o que está em alta entre os usuários. O monitoramento das tendências em tempo real é feito pelas plataformas digitais através do rastreamento do uso de metadados a partir de informações adicionais disponibilizadas pelos usuários em suas postagens, como palavras-chaves dotadas de hiperlinks - as hashtags -, ou etiquetas de geolocalização. Para o jornalismo praticado dentro do Instagram Stories, o uso de metadados é simplificado pela presença de etiquetas que oferecem essa personalização nas publicações.

Silveira (2016), ao explorar as diversas características possíveis do jornalismo ubíquo, destaca que a permanente relação entre pessoas e dispositivos móveis influencia a maneira como o produto jornalístico será recepcionado, visto que "o contexto da interação é fortemente importante, na medida em que auxilia na determinação do tipo de conteúdo que se quer consumir e do tipo de ação que se fará com aquela informação" (SILVEIRA, 2016, p. 257), a depender de sua localização ou situação.

Sobre a geolocalização, Ramos (2016) afirma que a questão do grande volume de dados atualmente demanda uma preocupação para além da distribuição de notícias, adicionando a possibilidade de pensar também em quais experiências serão proporcionadas pelas notícias no espaço em que a pessoa se encontra no momento. Com isso, um story publicado com o uso de uma etiqueta de localização pode se tornar um vetor de novas informações para o leitor, a fim de que ele navegue pela plataforma e faça conexões a partir da contextualização oferecida pelo produtor dos stories.

Entretanto, em nossa coleta os dados mostraram que tais recursos interativos foram pouco explorados pelos dois jornais analisados. Um fato notório envolvendo o uso de metadados de maneira estruturada povoou as mídias sociais e a sua cobertura, que se ampliaria nas semanas subsequentes, teve início na semana da nossa coleta. Em 25 de maio de 2020, George Floyd, um cidadão negro, foi brutalmente assassinado por um policial branco, em Minneapolis, nos Estados Unidos. O caso ganhou repercussão na quarta-feira, dia 27 , depois da divulgação de um vídeo que mostrava o policial ajoelhado em seu pescoço, apesar de a vítima dizer repetidamente "I can't breathe" ("Não consigo respirar", em português). Imediatamente, uma onda de protestos tomou diversas cidades dos Estados Unidos (e também de outros países), 
utilizando a hashtag \#BlackLivesMatter" ("Vidas Negras Importam") durante as manifestações nas ruas e nas redes sociais online. Usuários famosos e anônimos começaram a usar a hashtag em apoio ao movimento antirracista, como uma forma de cobrar as autoridades por medidas que protejam a população negra.

Sobre o fortalecimento do uso de metadados na organização e estruturação de movimentos sociais por meio das mídias sociais, Castells (2013) pontua o papel da mídia tradicional na visibilidade desses levantes populares. A respeito da cobertura jornalística da Primavera Árabe, a partir de 2010, o pesquisador acredita que os veículos de imprensa criaram "uma espécie de manto de proteção para movimento contra a repressão violenta", já que as autoridades "tentaram evitar embaraços em relação à opinião pública global, em função das injustificadas ações repressivas" (CASTELLS, 2013, p. 44). Criando um espaço público híbrido,

\begin{abstract}
a conexão entre a mídia social da Internet, as redes sociais das pessoas e a mídia tradicional tornou-se possível pela existência de um território ocupado que ancorava o novo espaço público na interação dinâmica entre ciberespaço e espaço urbano. [...]. A revolução da Internet não nega o caráter territorial das revoluções ao longo da história. Em vez disso, ela o estende do espaço dos lugares para o espaço dos fluxos. (CASTELLS, 2013, p. 44)
\end{abstract}

Como já citamos no segundo capítulo, tanto o Estadão, quanto a Folha, destinaram espaço para a cobertura dos protestos. Na quarta, cada perfil postou dois stories sobre o assunto e, na sexta, dia 29, com o crescimento das manifestações, os jornais estenderam a cobertura na plataforma. A Folha fez 10 postagens com informações sobre o caso, mas nenhuma delas possuía elementos de metadados, tais como a hashtag \#BlackLivesMatter ou a geolocalização dos protestos. No perfil do Estadão, foram publicados quatro stories sobre o assunto e, apesar de não terem hashtags, dois deles contavam com a etiqueta de geolocalização marcando a cidade de Minneapolis.

Nas figuras 3.13 a 3.15, é possível ver um exemplo de navegação em um cenário no qual o usuário decidisse explorar o hiperlink dentro da plataforma a partir dos stories publicados pelo perfil do Estadão. Ao clicar na etiqueta, o leitor é convidado a ver mais informações sobre a localização (fig. 3.13). Um clique em "ver localização"

70 O BLM, como também é conhecido o movimento, nasceu em 2013, após a absolvição de um vigia branco acusado de assassinar com um tiro no peito o adolescente negro Trayvon Martin, que voltava para casa após comprar doces no estado da Flórida. Desde então, o movimento tem organizado protestos, manifestações e ações nas mídias sociais 
leva a pessoa a uma página com um mapa da região e outras publicações que também utilizaram a mesma geolocalização (fig. 3.14), no feed e nos stories. Ao entrar na área de stories, uma sequência de publicações de outros usuários são mostradas. No exemplo (fig. 3.15), vemos um usuário que, além da localização, também utilizou a hashtag \#JusticeForGeorgeFloyd ("Justiça para George Floyd").

Figuras 3.13 a 3.15 - Stories sobre as manifestações do movimento Black Lives Matter

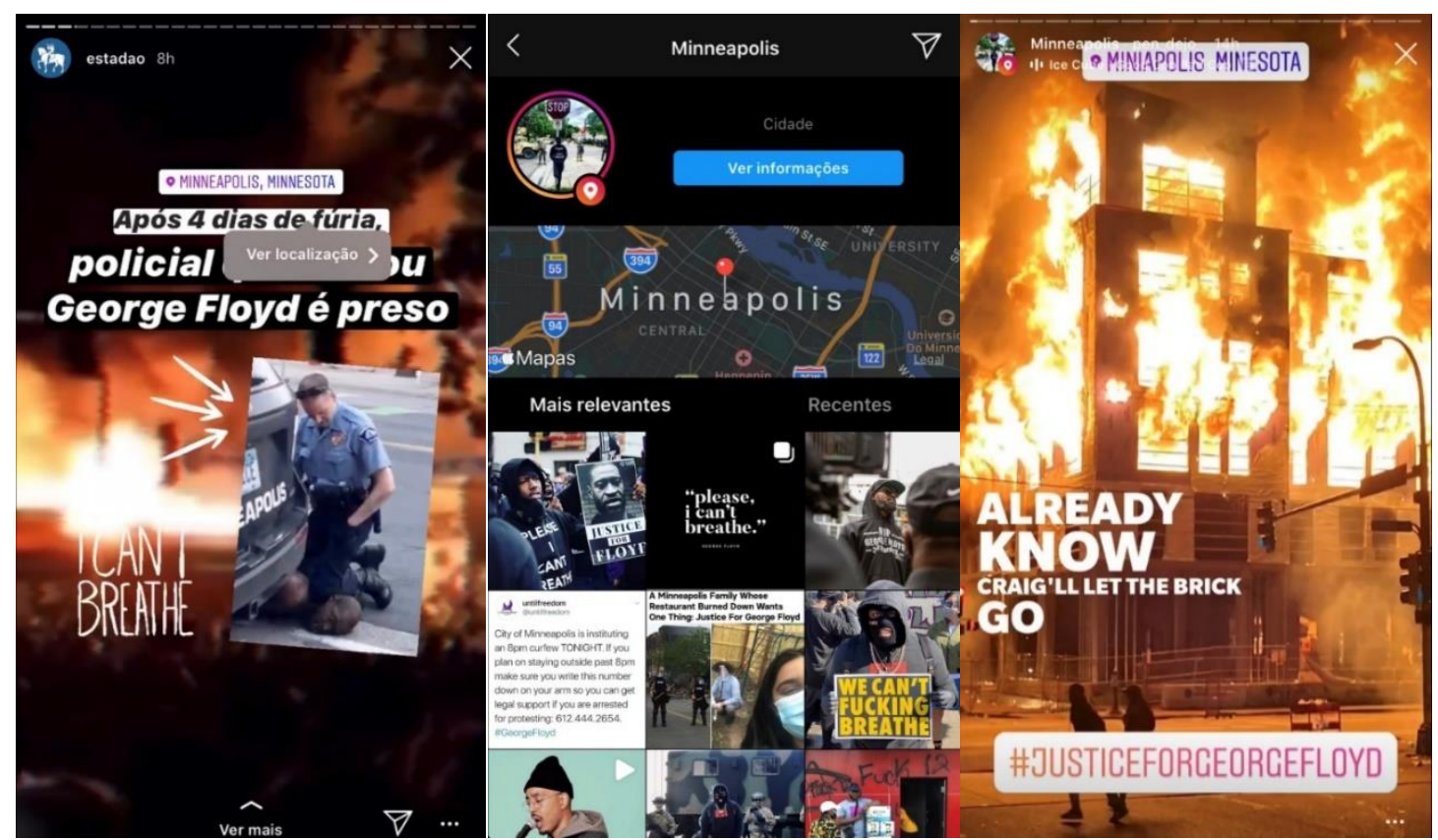

Fonte: captura de tela feita pela autora (2020)/ Reprodução Instagram

Além dos recursos interativos apresentados nesse tópico, os Stories oferecem outras funções relevantes para a prática jornalística. No próximo tópico abordaremos os valores comerciais presentes na produção de stories das empresas jornalísticas, tendo em vista as atuais formas de financiamento da cadeia de notícias. Veremos também como esses valores são apresentados e gerenciados através de ferramentas da plataforma, apropriadas pelos jornais para a geração de renda. 


\subsection{VALORES COMERCIAIS: RELAÇÕES HÍBRIDAS COM A PUBLICIDADE}

Muita coisa mudou dentro dos modelos de financiamento do jornalismo, principalmente nas duas últimas décadas. Bell e Owen (2017) citam três mudanças importantes no modelo de negócios e de distribuição do jornalismo: a migração do analógico para o digital, o advento de mídias sociais e, hoje, a primazia dos dispositivos móveis. Foi justamente nessa última virada que as grandes empresas de tecnologia passaram a dominar o mercado de audiência e publicidade. Todas essas transformações forçaram o jornalismo a criar novas fontes de renda, obrigando os veículos a reavaliarem seus processos e estruturas.

Com a necessidade de conduzir as pessoas das plataformas aos seus sites, justamente pelo fato de as empresas dependerem fortemente das receitas geradas pelos cliques de seus leitores, começou a crescer a necessidade de competir com os demais sites pela atenção do público.

Para atrair os leitores a clicarem em um artigo e, posteriormente, visitarem o
site da mídia, os meios de comunicação costumam apresentar manchetes
cativantes que acompanham os links do artigo, que induzem os leitores ao
clique. Esses títulos são conhecidos como Clickbaits. [...] a longo prazo, os
clickbaits geralmente não correspondem às expectativas dos leitores e os
deixam desapontados. ${ }^{71}$ (CHAKRABORTY et al, 2016, p. 9, tradução nossa)

A cultura dos cliques, que contribuiu para o fenômeno do clickbait, foi uma das responsáveis pela propagação de desinformação na última década. Contudo, como aponta Bradshaw (2014), a evolução das métricas de publicidade mostra que a qualidade do consumo vem se tornando mais relevante para os anunciantes do que a quantidade de pessoas alcançadas a partir da contabilização de visualizações. Nos últimos anos, cresceu o apelo ao engajamento, ou seja, ao relacionamento entre jornais e audiência. Uma prova disso é o que vimos no tópico anterior, já que a interação passou a ser um fator essencial para a atuação dos jornais nas redes online.

Em 2019, em mais um relatório da Tow Center for Digital Journalism, mesma instituição que publicou o estudo de Bell e Owen (2017), observamos um novo capítulo na relação entre jornalistas e plataformas. Com o título "Plataformas e publishers: o

71 "To attract the readers to click on an article and subsequently visit the media site, the outlets often come up with catchy headlines accompanying the article links, which lure the readers to click on the link. Such headlines are known as Clickbaits. While these baits may trick the readers into clicking, in the long-run, clickbaits usually don't live up to the expectation of the readers, and leave them disappointed." 
fim de uma era", a pesquisa mostra que as organizações de notícia estão cada vez mais focadas em atender a seus leitores regulares, e a tendência é trazê-los para os canais de propriedade dos veículos, ao invés dos canais via redes sociais online (RASHIDIAN et al, 2019).

Em conjunto com esse fenômeno, vemos outras mudanças na relação entre jornalistas e anunciantes, que estão tornando as fronteiras entre informação jornalística e publicidade cada vez mais indefinidas.

\subsubsection{OS STORIES E O FINANCIAMENTO DO JORNALISMO}

A busca por fontes de renda alternativas fez com que as empresas jornalísticas desenvolvessem novas estratégias de distribuição de notícias e novas táticas de publicidade. Uma das mais populares é o paywall, um "muro" metafórico em seus sites, que funciona como barreira e bloqueia a visualização das notícias na íntegra, a não ser que o leitor assine um dos planos oferecidos para acessar o conteúdo.

Além dessa estratégia, as empresas ampliaram as abordagens publicitárias para geração de renda por meio de ações de marketing direto (GABRIEL; RISO, 2020), um sistema interativo de marketing que faz uso de uma ou mais mídias para obter respostas dos consumidores na forma de dados ou de outras informações mensuráveis. Ao contrário da propaganda, que utiliza o marketing de interrupção, no marketing direto marcas e público-alvo formam um relacionamento e interagem. No Instagram, a principal ferramenta de "chamada para ação" (ou CTA, sigla em inglês para call-to-action) são os links. Os jornais analisados utilizam esse recurso para transportar a audiência dos stories para seus sites e também para outros formatos de atividades patrocinadas. Destacamos algumas a seguir:

a) Paywall e assinatura digital: enquanto o Estadão adota o paywall total ${ }^{72}$ (fig. 3.16 e 3.17), a Folha possui o modelo de paywall "poroso" (fig. 3.18 e 3.19), ou seja, oferece o acesso a um número limitado de notícias por um período e, ao encerrar

72 Estadão e a Folha utilizam essa estratégia em seus sites, mas, durante o período de pandemia, os jornais abriram algumas exceções em notícias com informações essenciais para o público. Para saber mais: https://propmark.com.br/midia/jornais-derrubam-paywall-em-materias-sobre-coronavirus/ 
essa quantidade, o usuário é impedido de prosseguir lendo, sendo então convidado a assinar um dos planos de assinatura disponibilizados;

Figura 3.16 a 3.19 - Exemplos de usos do paywall e de anúncios de assinatura

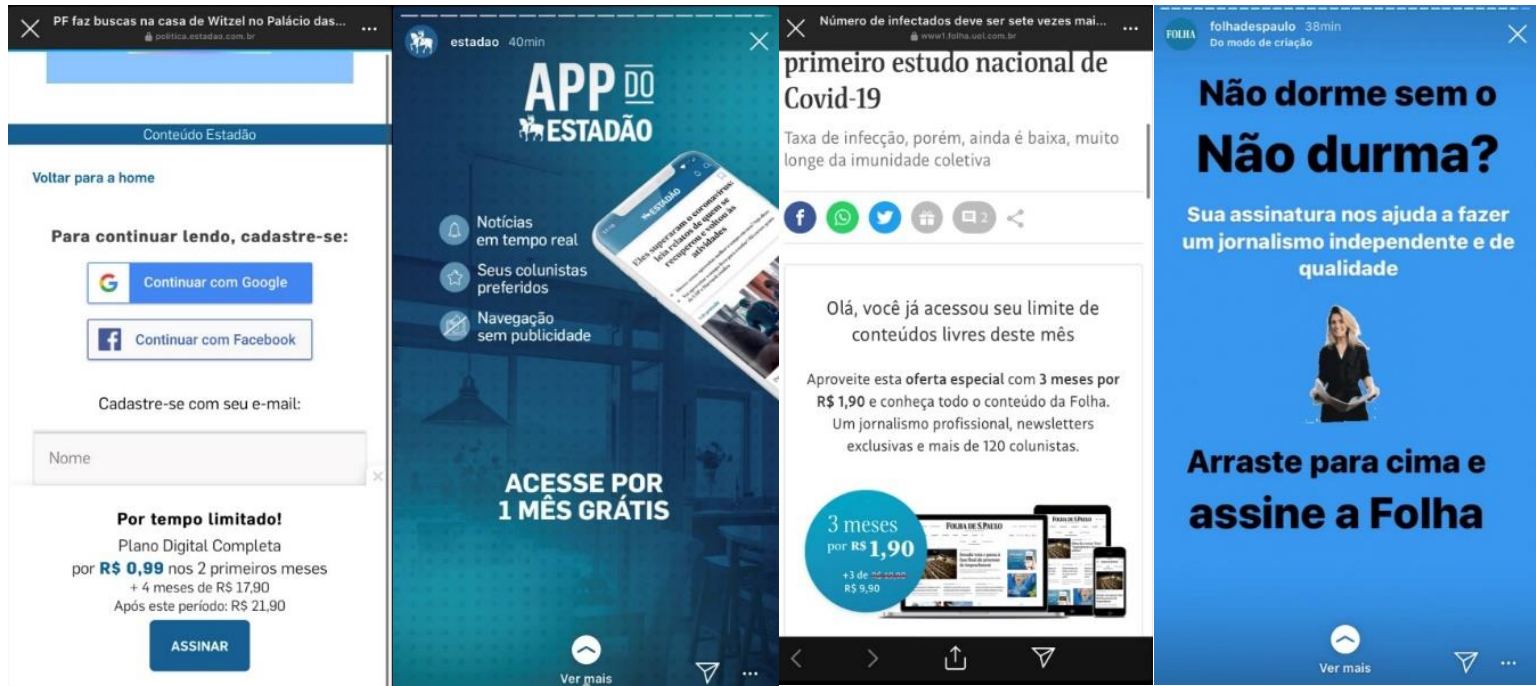

Fonte: captura de tela feita pela autora (2020)/ Reprodução Instagram

b) Branded content: o branded content é uma forma relativamente nova de publicidade online, em que a informação do anunciante é formatada para ser uma peça publicitária com a aparência similar ao do conteúdo não publicitário da mídia em que foi publicada que, no nosso exemplo, é o jornalismo do Estadão. Por ser parecido com o conteúdo jornalístico, o branded content não interrompe a experiência do usuário e não possui apelo de venda direta, pois trata-se de uma mistura entre jornalismo e publicidade, tornando indiscerníveis as fronteiras entre as duas áreas (RIBEIRO JR., 2019). Como já mostrado no segundo capítulo, a parceria de branded content entre o jornal e a Ágora Investimentos é responsável por parte dos stories publicados sobre finanças e economia. Na figura 3.20, o jornalista apresenta a notícia com menção integrada ao story para o perfil @estadaoinvestidor (fig. 3.21) e com um link para ver mais no site. Dentro do link, no final da matéria, existe uma frase (fig. 3.22) que incentiva o cadastro na Ágora Investimentos, mas não é claro o relacionamento entre as duas empresas. Descobrimos a natureza comercial da parceria apenas na página de expediente do site (fig. 3.23); 
Fig. 3.20 a 3.23 - E-Investidor nos stories e no site do Estadão

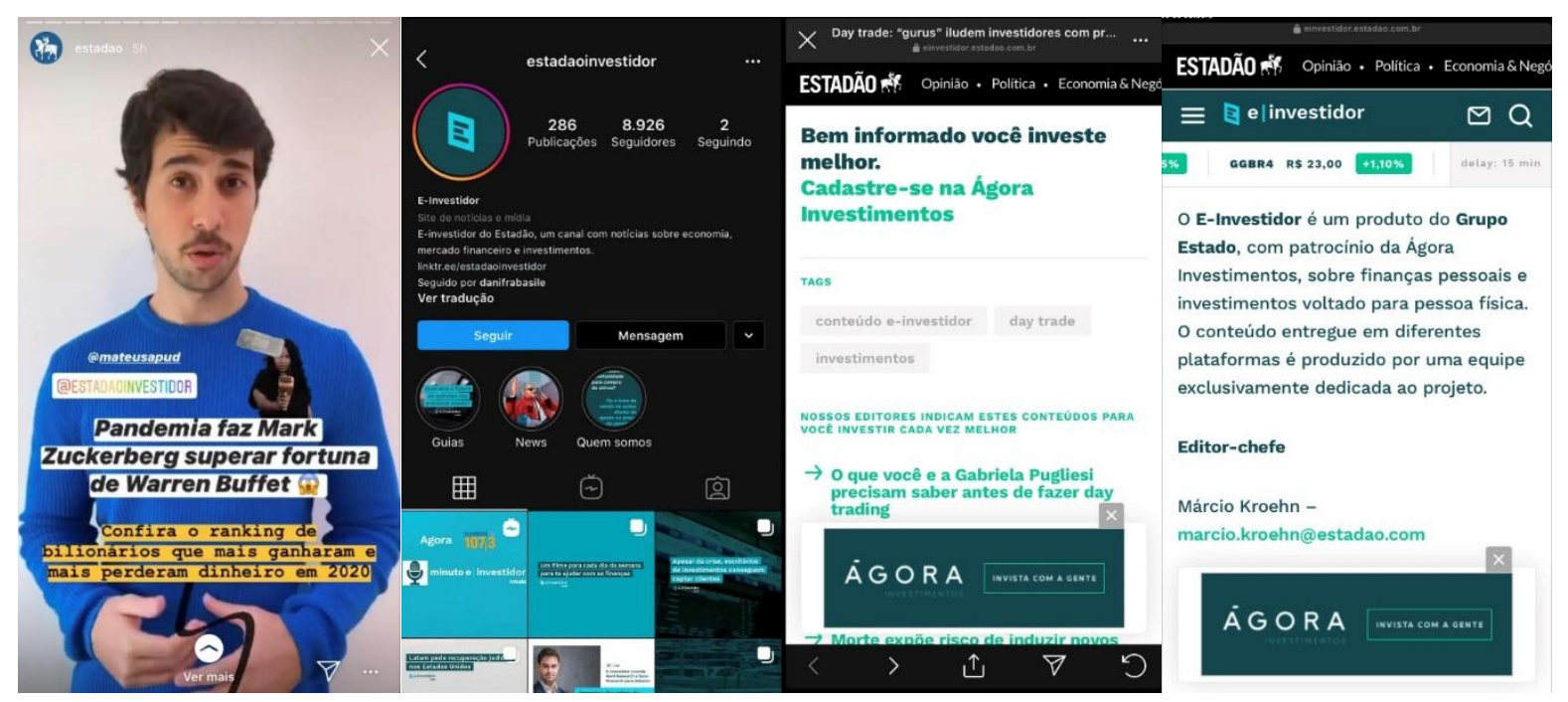

Fonte: captura de tela feita pela autora (2020)/ Reprodução Instagram

c) Eventos patrocinados: o Media Lab Estadão organiza e divulga eventos de empresas dentro das mídias sociais do jornal, como visto na figura 3.24. Além de promover as marcas, também existe a captação de dados pessoais de usuários (fig. 3.25) por meio de cadastros para ter acesso aos eventos, um ativo precioso dentro do mundo do marketing digital;

Fig. 3.24 e 3.25 - Eventos patrocinados nos stories do Estadão

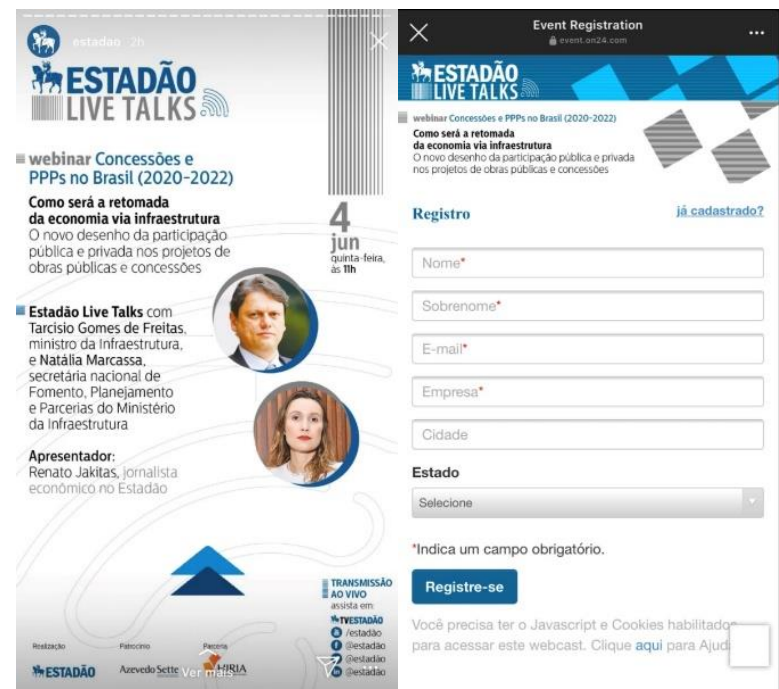

Fonte: captura de tela feita pela autora (2020)/ Reprodução Instagram

d) Coleções: na década de 1990, para incentivar o aumento das tiragens de jornal impresso, a Folha passou a encartar nas edições de domingo fascículos e outros itens colecionáveis (CHRISTOFOLETTI, 2019). Essa forma de financiamento 
continua ativa, agora também no digital, a partir do site Coleções Folha. Seguindo a tradição, o jornal promoveu uma coleção de livros nos stories de domingo (fig. 3.26), colocando links externos (fig. 3.27) e também para o perfil @colecoesfolha (fig. 3.28).

Fig. 3.26 a 3.28 - Coleções Folha nos stories do jornal

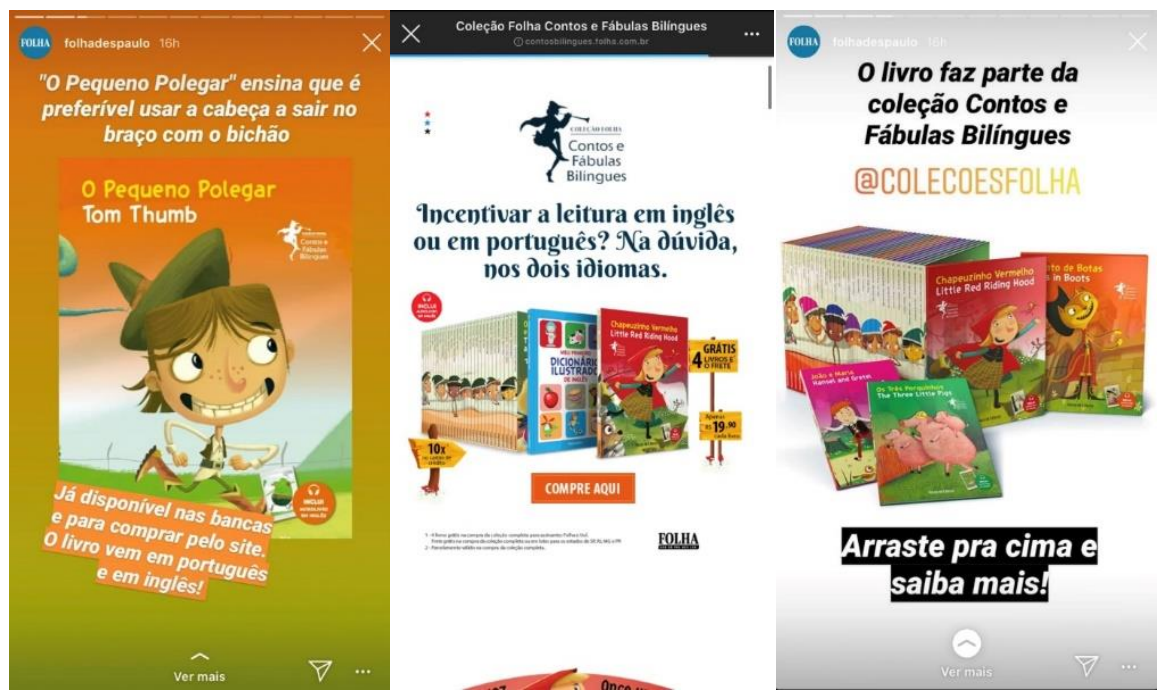

Fonte: captura de tela feita pela autora (2020)/ Reprodução Instagram

Além desses exemplos citados, existem muitas outras possibilidades de captação de recursos financeiros com o auxílio dos Stories. A seguir, veremos como funciona a função parceria paga, integrada à plataforma.

\subsubsection{AS PARCERIA PAGAS E A MONETIZAÇÃO VIA STORIES}

Em 2017 o Instagram criou o selo de "parceria paga", tanto para as publicações do feed da galeria tradicional, como para os stories. A ferramenta, segundo o Instagram ${ }^{73}$, foi lançada para dar mais opções para criadores e marcas, além de estimular a transparência dentro da plataforma, pois a marcação serviria também para ajudar o público a identificar quando uma postagem é patrocinada. Por outro lado, o mecanismo também aumenta a exposição da marca patrocinadora e inclui um hiperlink direto para o perfil do anunciante. 
Com o selo, o perfil do anunciante também tem acesso às estatísticas relacionadas à publicação dos veículos, como número de pessoas alcançadas, número de cliques, entre outras. Durante a coleta, não encontramos no perfil da Folha postagens com o recurso de parceria paga. Já no Estadão, a ferramenta foi utilizada em algumas ocasiões. Destacamos a seguir três ocorrências que exemplificam o seu uso:

a) Podcasts: o "Notícia no seu tempo" é um podcast publicado de segunda à sábado, às $5 \mathrm{~h}$ nas principais plataformas de streaming na Internet ${ }^{74}$. No exemplo destacado (fig. 3.29), a imagem mostra o logotipo da CCR, Mitsubishi, Veloe e Estadão. As duas primeiras empresas aparecem apenas em uma citação textual, enquanto a Veloe ganhou também espaço no hiperlink da ferramenta do Instagram para parcerias pagas, na parte superior do story. Ao clicar no nome da empresa, a pessoa é direcionada para o perfil da Veloe (fig. 3.30) dentro do Instagram;

Figura 3.29 e 3.30 - Monetização de podcasts divulgados nos stories

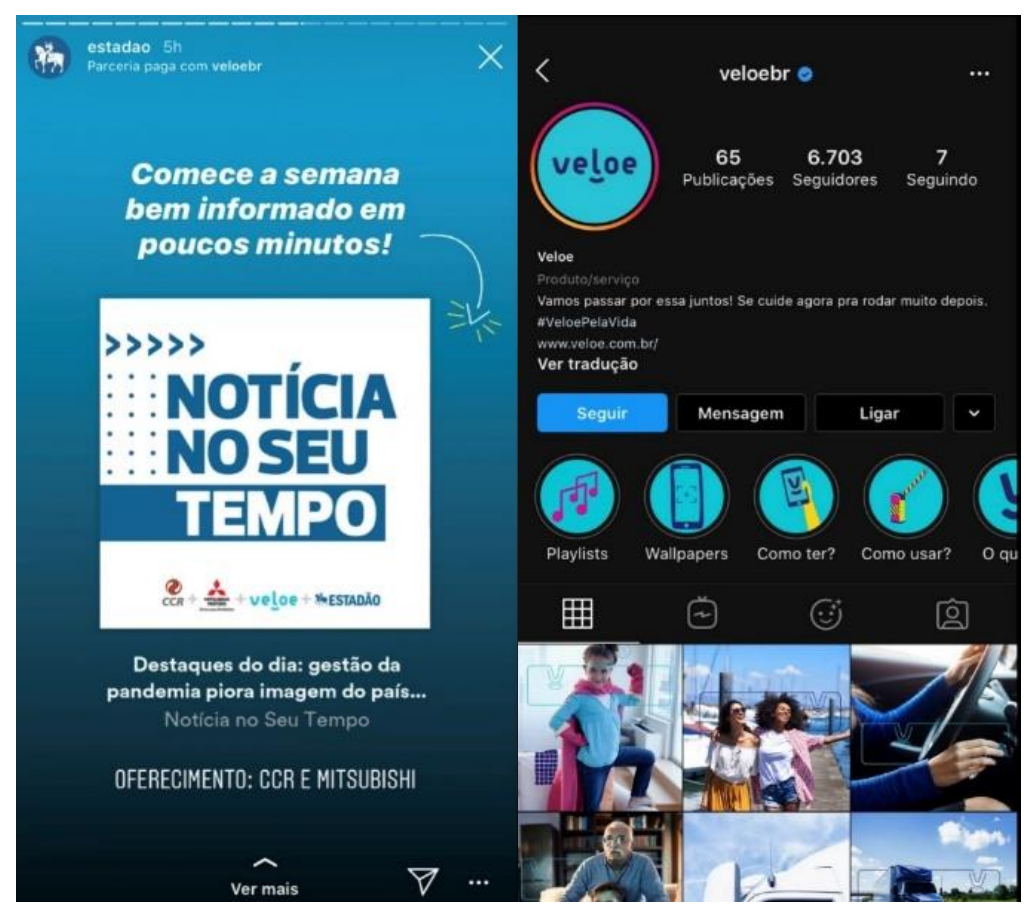

Fonte: captura de tela feita pela autora (2020)/ Reprodução Instagram

74 O link no story direciona o usuário para a plataforma Spotify. No entanto, segundo o site do Estadão, ele também está disponível em outras empresas de streaming. Para saber mais: https://economia.estadao.com.br/noticias/geral,quer-ficar-bem-informado-ouca-o-podcast-noticia-noseu-tempo,70002891139 
b) Repostagem: o recurso de parceria paga, como explicamos, pode ser utilizado tanto nos stories como no feed dos perfis do Instagram. No exemplo a seguir (fig. 3.31), o jornal promoveu em seu espaço temporário uma publicação de sua galeria permanente por meio do recurso de repost (repostagem). Quando o usuário clica na imagem, ele é direcionado para a postagem (fig. 3.32). Outra opção seria acessar o link na parte inferior do story, que levava a audiência ao site do Media Lab Estadão (fig. 3.33).

Figura 3.31 a 3.33 - Divulgação de postagens patrocinadas nos Stories

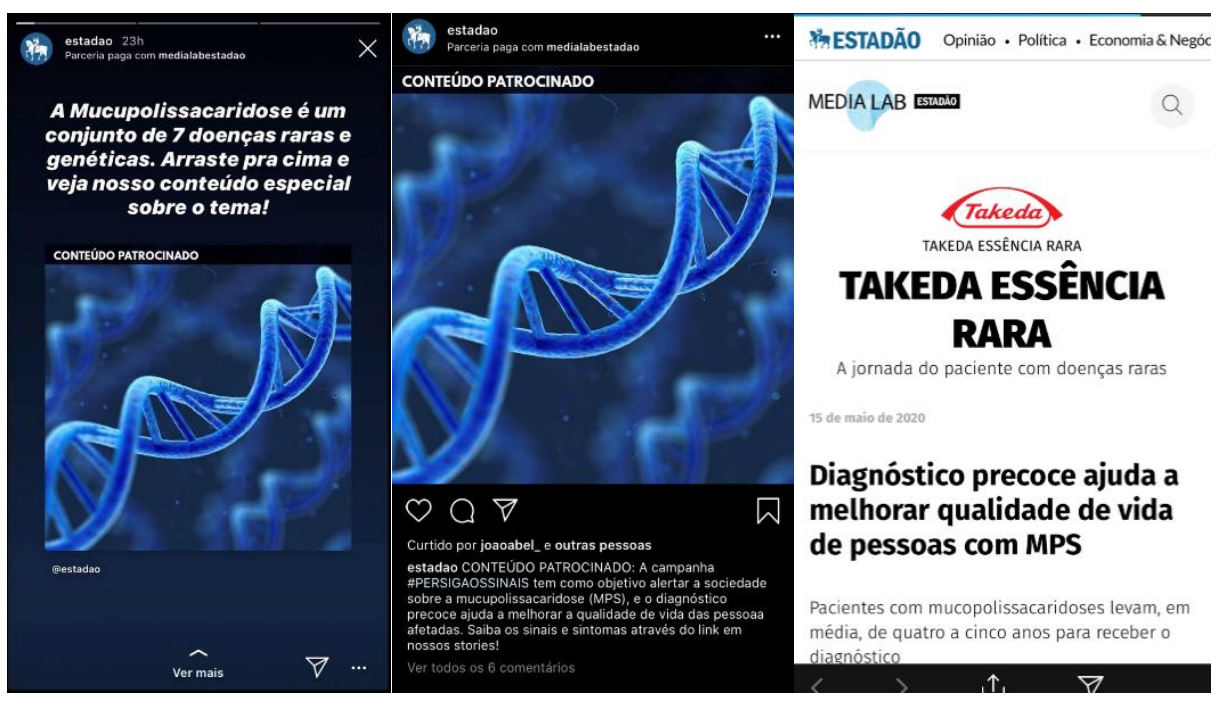

Fonte: captura de tela feita pela autora (2020)/ Reprodução Instagram

c) Realidade aumentada: o Instagram permite a criação colaborativa de filtros de realidade aumentada ${ }^{75}$. Essa ferramenta é usada por usuários da plataforma e também por marcas. No exemplo selecionado, a empresa Cielo lançou uma campanha em uma parceria paga com o perfil do Estadão. Com a intenção de promover valores como a união entre amigos e familiares durante o período da pandemia, a ação incentivava o uso do filtro personalizado do mascote da Cielo, com a hashtag \#sintaseabraçado e as menções aos perfis do @estadao e @cartaoelo, além dos perfis do jornalista e de sua sobrinha (figuras 3.34 a 3.36).

${ }^{75}$ Realidade aumentada é uma tecnologia utilizada para unir o mundo real com o virtual, através da inserção de objetos virtuais no ambiente físico, mostrada ao usuário em tempo real na tela de um dispositivo móvel, como um smartphone. 
Figura 3.34 a 3.36 - Parceria com a Cielo com uso de filtro de realidade aumentada

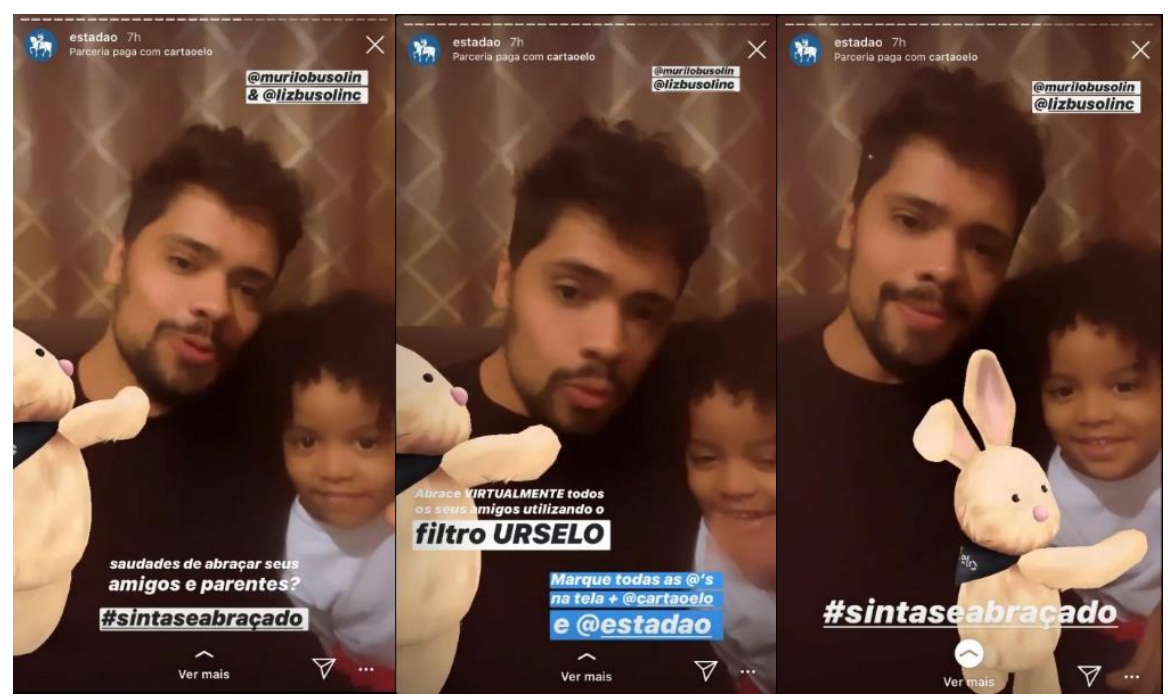

Fonte: captura de tela feita pela autora (2020)/ Reprodução Instagram

Vimos, no exemplo anterior, um profissional do Estadão com a sua sobrinha fazendo um anúncio publicitário envolvendo um urso de pelúcia virtual e uma campanha incentivando abraços feita pela Cielo, uma empresa de serviços financeiros. Apesar de parecer inusitada e inesperada, essa parceria paga ilustra uma prática típica da economia afetiva (JENKINS, 2009).

Dentro desse novo contexto, as empresas buscam se aproximar do público estimulando sentimentos e interações quem criem conexões emocionais com os consumidores. Com elementos de entretenimento, o branded entertainment (GABRIEL; KISO, 2020) é uma estratégia que torna a publicidade uma experiência mais imersiva e menos interruptiva como nos anúncios tradicionais.

Com a reconfiguração do cenário de mídias, as empresas de jornalismo começam a enxergar nesses espaços emergentes uma oportunidade para se aproximarem de novos públicos, especialmente por entenderem que o cenário de convergência oferece um fluxo de conteúdos que percorrem múltiplos canais de comunicação (JENKINS, 2009). Assim, estar presente nos Stories ultrapassou o propósito de simples vitrine e tomou contornos estratégicos, transformando-se em um importante canal para o ecossistema jornalístico como um todo.

No próximo tópico, abordaremos com mais profundida a influência do entretenimento e da cultura audiovisual nas postagens jornalísticas dentro dos Stories. 


\subsection{VALORES AUDIOVISUAIS: O CULTO AO ENTRETENIMENTO}

Os efeitos da cultura da convergência e da plataformização não chegaram apenas ao jornalismo, mas também à publicidade, como vimos nos tópicos anteriores, através da observação de valores interativos e comerciais que coexistem no ambiente dos Stories. O conjunto que analisaremos agora é o dos valores audiovisuais, um aspecto que não é restrito ao mundo dos smartphones, mas que também perpassa todos os demais suportes telemidiáticos, seguindo as características de cada um. Nos Stories, esses valores ganham um protagonismo sem precedentes.

No último tópico, demos como exemplo um anúncio publicitário, nos Stories do Estadão, feito com um urso de pelúcia virtual abraçado a um profissional do Grupo, graças a uma camada de realidade aumentada de um filtro criado por uma empresa de serviços financeiros. Em 2017, o jornalista que aparece nas imagens, Murilo Busolin, foi o responsável pela criação do Drops, o programa diário publicado no Instagram Stories do perfil do jornal Estadão, no qual também era apresentador. Atualmente, Busolin é coordenador no Media Lab Estadão e publica textos sobre cultura e entretenimento na coluna No Sofá, do blog Divirta-se, do Estadão. Busolin ainda faz aparições periódicas nas postagens dos Stories, que agora segue sob a apresentação e produção dos jornalistas João Abel e Bárbara Pereira. Durante uma entrevista para uma publicação acadêmica, Busolin falou sobre o novo perfil do profissional do jornalismo na era das plataformas digitais:

[...] acho que é o futuro do jornalismo ser multimídia. Estou vendo muito lugar colocar vaga para criação de conteúdo que envolve tudo, envolve site, envolve texto, envolve redes sociais principalmente. Mas o que eu mais vejo da evolução do jornalista é como um profissional multimídia. Se você não está antenado com as redes sociais no momento, não está sabendo o que está nos Trending Topics, se você não está conectado com as redes, você fica um pouco para trás. (SERPA, 2019, p. 87)

A exigência de um perfil multimídia dos profissionais é um dos reflexos das constantes hibridizações sofridas pelas redações das empresas de jornalismo, que cada vez mais buscam produtos multiplataformas com atrativos para a audiência. Com a exposição de seu perfil pessoal nos Stories do Estadão, Busolin, assim como os demais jornalistas da equipe, obteve em sua conta pessoal o selo de autenticidade 
(figuras 3.37), dado pelo Instagram ao usuário que necessitam comprovar a "presença autêntica da figura pública, da celebridade ou da marca global que representa"76.

Os aspectos dos valores audiovisuais, disponíveis nos recursos e ferramentas dentro dos Stories, também funcionam como caminho para expressar novas formas de visibilidade nas redes. Na figura 3.37, Busolin faz uma participação pontual ao fim do Drops de sexta, 29 de maio, indicando uma música para fechar a edição do dia. jornalista aparece usando um filtro de realidade aumentada com o nome do novo álbum da cantora Lady Gaga, Chromatica, por conta de sua escolha musical. Antes desse story, o jornalista João Abel (fig. 3.38), havia destacado na edição do dia o lançamento do disco, também fazendo uso de um filtro e da hashtag \#sextou ${ }^{77}$.

\section{Figura 3.37 - Menção nos Stories do @estadao do perfil de @murilobusolin, criador do Drops e, ao lado, duas capturas de tela que mostram o perfil do jornalista sem (parte superior) e com (parte inferior) o selo de autenticidade do Instagram.}
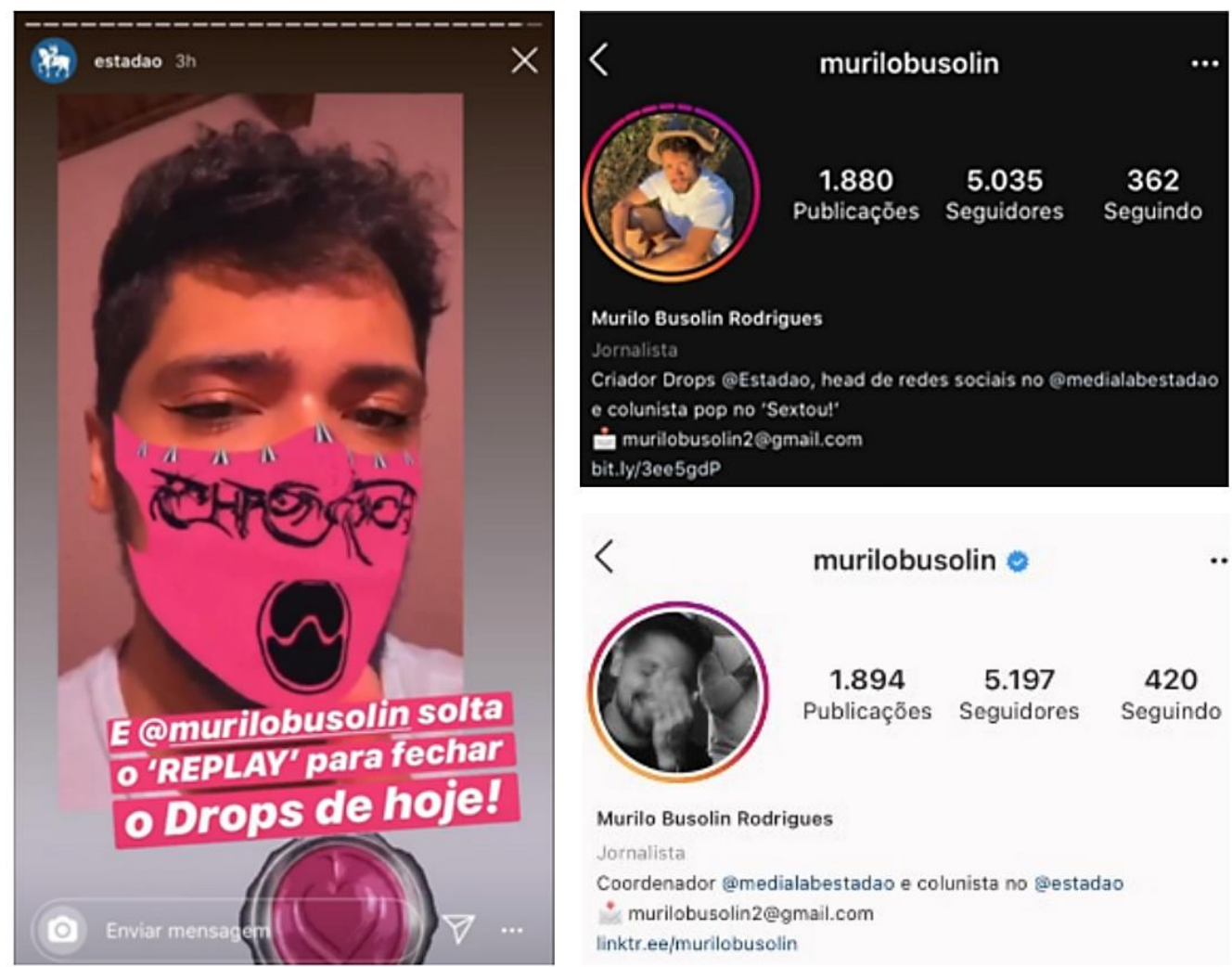

Fonte: captura de tela feita pela autora (2020)/ Reprodução Instagram

${ }^{76}$ O selo de autenticidade, representado por uma marcação azul, foi atribuído aos profissionais após o mês de maio, época em que foi feita a coleta da nossa pesquisa e a primeira captura de tela com o perfil da equipe. As imagens dos perfis com o selo foram registradas em novembro. Para saber mais: "O que é um selo de autenticidade no Instagram?" Disponível em: https://help.instagram.com/733907830039577

77 Os usuários brasileiros de redes sociais na Internet utilizam a hashtag \#sextou para comemorar a chegada da sexta-feira e a proximidade do fim de semana 
Figura 3.38 - Menção nos Stories do @estadao do perfil de @joaoabel_, editor do Drops e, ao lado, duas capturas de tela que mostram o perfil do jornalista sem (parte superior) e com (parte inferior) o selo de autenticidade do Instagram.

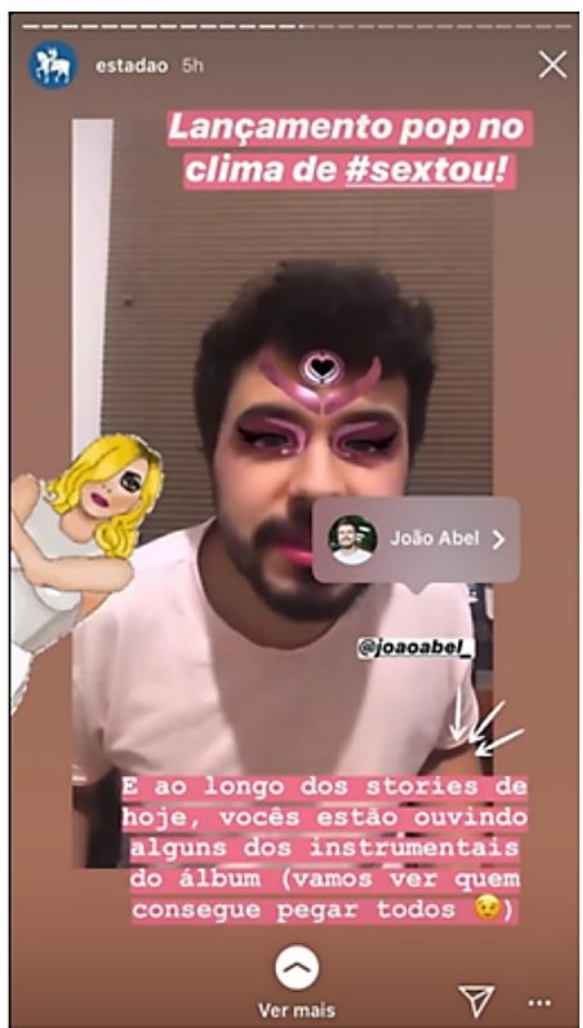

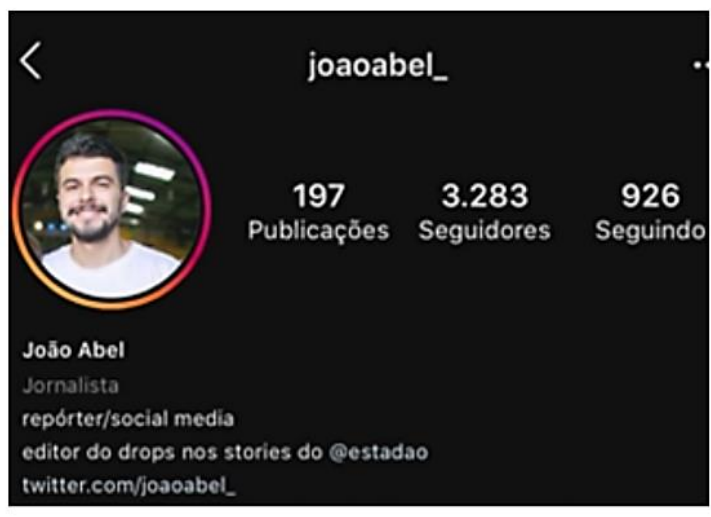

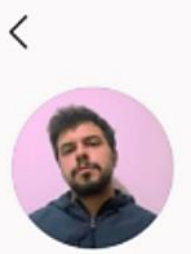

joaoabel_e

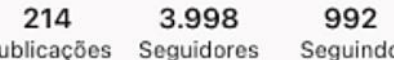

João Abel

Jornalista

repórter/social media

editor do drops nos stories do @estadao

autor de 'bicha' e coautor de 'o contra-ataque'

www.edprimeirolugar.com.br/bicha

Os perfis dos jornalistas servem como exemplo de um fenômeno que atinge não apenas os profissionais do jornalismo, mas todas as pessoas que possuem perfis públicos nas redes sociais online, que é a exibição da intimidade, estudada pela pesquisadora Paula Sibilia (2016). Com a expansão do campos da visibilidade por meio das telas, aparecer passa a ter cada vez mais importância para ser. As vidas cotidianas são coloridas com comportamentos antes restritos às celebridades e a personalidades da área do entretenimento, ampliando os indivíduos dispostos a performar "suas personalidades e encenar suas vidas na visibilidade das telas interconectadas" (SIBILIA, 2016, p. 31).

No compasso de uma cultura que se ancora crescentemente em imagens, desmonta-se o velho império da palavra e proliferam fenômenos nos quais as lógicas da visibilidade e da conexão constante desempenham papéis primordiais na construção de si e da própria vida como um relato. (SIBILIA, 2016, p. 79) 
Com um ambiente repleto de influenciadores digitais (KARHAWI , 2016) e com o peso colocado pelo capitalismo artista (LIPOVETSKY; SERROY, 2015) na criatividade e na expressão dos indivíduos na esfera midiática, o esforço para obter sucesso no Instagram é maior. É preciso realçar a personalidade e um dos modos de fazer isso é a partir do uso de imagens e sons para chamar a atenção do público, principalmente os mais jovens: vídeo, música, filtros de realidade aumentada e gifs. Os recursos de metadados complementam o ambiente de conexões entre as figuras públicas, através das etiquetas de menção aos jornalistas, e o conteúdo gerado pelo usuário, a partir da hashtag \#sextou ${ }^{78}$.

Percebemos, com isso, a materialização digital do desejo de transformar em espetáculos fascinantes os simples momentos cotidianos da vida, por meio do uso de ferramentas que simplificam o design e de filtros de realidade aumentada que modificam rostos e ambientes. Isso nos permite pensar na possibilidade de uma "aparelhagem técnica da visibilidade" (SIBILIA, 2016, p. 312) mais acessível às pessoas, antes restrita apenas às celebridades do cinema e da televisão.

Hoje, "a realidade se apresenta ela mesma como um efeito especial do entretenimento" (HAN, 2019, p. 9, grifo do autor). Para além de um simples passatempo, as práticas de entretenimento passam a ocupar um papel de destaque na sociedade. Segundo o filósofo Byung-Chul Han (2019), a ubiquidade do entretenimento tem causado uma mudança fundamental na forma como as pessoas compreendem o mundo e a realidade.

O entretenimento se eleva a um novo paradigma, a uma nova fórmula de mundo e de ser. Para ser, para pertencer ao mundo, é preciso ser algo que entretém. Apenas aquilo que entretém é real ou efetivo. [...] A própria realidade parece ser um efeito do entretenimento. (HAN, 2019, p. 206)

Em vez de se tratar de uma atividade com horário e funções definidas, o fenômeno do entretenimento ultrapassa a fronteira do tempo livre e se torna um novo modo de viver a vida, em todos os momentos. Han (2019) afirma que o entretenimento, atualmente, perpassa todo o sistema social, incluindo as áreas de educação, política, saúde e, como não poderia ser diferente, da comunicação e do jornalismo. Ao entrar em contato com essas outras instâncias, surgem formatos

\footnotetext{
${ }^{78}$ Cabe pontuar que a hashtag \#sextou foi banida do Instagram em 2018 após ter sido "reinterpretada" por perfis estrangeiros para postagem de conteúdo pornográfico (a gíria "sex to u", em inglês, significa "sexo para você"). Ver mais: https://claudia.abril.com.br/noticias/hashtag-sextou-banida-instagram/
} 
híbridos como, por exemplo, o infotenimento, que mescla entretenimento às notícias. O neologismo não é um conceito recente, mas tem encontrado terreno fértil dentro do ambiente das redes sociais online. Surgiu na década de 1980 e se espalhou pela imprensa mundial nas décadas seguintes (DEJAVITE, 2007). O jornalismo de infotenimento pode ser definido como um

[...] espaço destinado às matérias que visam informar e entreter, como, por exemplo, os assuntos sobre estilo de vida, as fofocas e as notícias de interesse humano. Esse termo sintetiza, de maneira clara e objetiva, a intenção editorial do papel de entreter no jornalismo, pois segue seus princípios básicos que atende às necessidades de informação do receptor de hoje. Enfim, manifesta aquele conteúdo que informa com diversão. (DEJAVITE, 2007, p. 2)

A seguir, vamos explorar o contexto no qual se inserem esses exemplos, trazendo para a nossa discussão conceitos sobre a cultura dos influenciadores digitais e sobre o uso de temas ligados ao entretenimento audiovisual como estratégia para atrair consumidores mais jovens para o espaço jornalístico.

\subsubsection{O JORNALISMO SELFIE NO MUNDO DOS INFLUENCIADORES DIGITAIS}

As selfies são um dos fenômenos mais notáveis dentro do ambiente de mídia digital atual, local em que se popularizou, principalmente devido ao avanço das tecnologias dos dispositivos digitais com câmera integrada (em especial, os smartphones) e das mídias sociais online. "Era apenas uma questão de tempo até que as selfies fossem incorporados às práticas jornalísticas atuais", defende Maniou e Veglis (2016, p. 111, tradução nossa ${ }^{79}$ ), a partir de estudos sobre o jornalismo selfie, termo traduzido do inglês selfie journalism.

O jornalismo selfie pode ser descrito como uma nova tendência do jornalismo participativo e cidadão, exercida via dispositivos móveis e baseada na prática de postar autorretratos (e/ou vídeos) nas redes sociais e - desta forma reproduzir conteúdo, não baseados em objetos / pessoas / imagens isolados etc., mas em artefatos que enquadram o 'autor' da fotografia; na maioria das vezes, esses artefatos (sejam objetos / premissas ou outras pessoas) constituem elementos da vida privada do autor, que, assim, tornam-se intencionalmente públicos, com o objetivo de atrair a atenção de outras pessoas e provocar reações (positivas) em público. (MANIOU; PANAGIOTIDIS; VEGLIS, 2019, p. 585, tradução nossa ${ }^{80}$ ).

79 "it was only a matter of time for selfies to be incorporated in the current journalistic practices"

80 "Selfie Journalism could be described as a new tendency in participatory and citizens journalism, exercised via mobile devices and based on the practice of posting self-photographs (and/or videos) in 
Apesar de recente, o jornalismo selfie já é utilizado pelos principais veículos do mundo, principalmente porque as mídias sociais apresentam potencialidades para a apropriação desse tipo de jornalismo na transmissão de notícias (ALVES; SILVA, 2018). Além de passar um aspecto mais pessoal e mais íntimo, essa modalidade de fotografia, feita principalmente com a câmera frontal dos smartphones, também serve para transmitir dados de contexto, à medida em que ela também é usada para mostrar a presença da pessoa em um evento ou local específico, se ela está sozinha ou acompanhada, entre outras informações.

Tendo em vista as novas possibilidades de produção de conteúdo, observamos que o Estadão utilizou a modalidade de jornalismo selfie em algumas ocasiões. Devido à limitação imposta pelo isolamento social durante a quarentena e a transferência de atividades presenciais para o ambiente de home office, os apresentadores do Drops passaram a divulgar as notícias diretamente de suas casas. Fora do cenário de trabalho da redação jornalística, os elementos imagéticos adicionados à imagem ganham ainda mais destaque.

$\mathrm{Na}$ figura 3.39, destacamos uma passagem em que a apresentadora Bárbara Pereira aparece comentando uma notícia sobre o embate entre o presidente dos Estados Unidos, Donald Trump, e a plataforma Twitter, publicada na semana analisada de maio. As capturas de tela das mensagens trocadas pelos dois envolvidos na rede social enriqueceram o conteúdo do story, ampliando o contexto informativo para além da simples ilustração. Compõem a imagem também os gifs e a etiqueta de menção com o nome de usuário da jornalista no Instagram. Além de identificá-la, o recurso oferece um hiperlink para que a audiência do jornal visite o seu perfil público, onde ela se define como "criadora de conteúdo digital", posição que engloba as suas atividades como jornalista e blogueira.

social media and - in this way - reproducing content, not based on isolated objects/people/images, etc., but on artefacts framing the 'author' of the photograph; most of the times, these artefacts (either objects/premises or other people) constitute elements of the author's private life, which, thus, becomes intentionally public, aiming to attract other people's attention and provoke (positive) reactions in public." 
Figura 3.39 - Menção nos stories do @estadao do perfil de @barbara_pereira, apresentadora do Drops e, ao lado, duas capturas de tela que mostram o perfil da jornalista sem (parte superior) e com (parte inferior) o selo de autenticidade do Instagram.
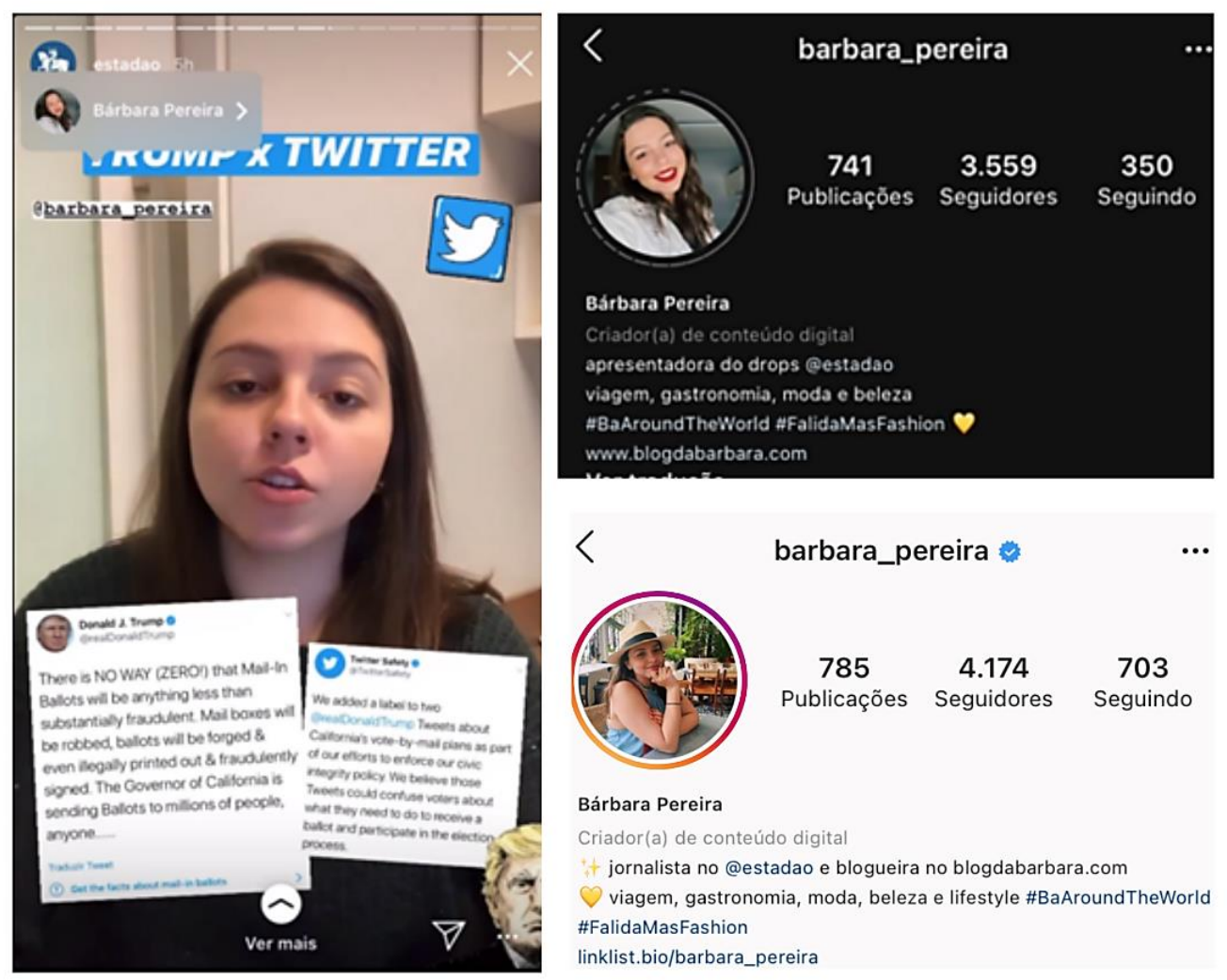

Fonte: captura de tela feita pela autora (2020)/ Reprodução Instagram

Influenciadores digitais, atletas e outras celebridades também marcaram presença comentando a produção jornalística e convidando a audiência para participar de eventos ou conteúdos que tiveram as suas colaborações (figuras 3.40). Essa ação interliga os leitores do jornal aos seus seguidores, por meio de condutas valorizadas dentro do âmbito do marketing de influência, como a credibilidade, a autenticidade e a confiança que são passadas pela imagem que constroem nas redes sociais (SIBILIA, 2016).

Dentro da cultura do jornalismo selfie, não são apenas os profissionais da notícia que podem praticá-lo. A revolução digital possibilitou que cidadãos comuns se convertessem em potenciais criadores de imagens com valor-notícia, transformando o jornalismo selfie em uma das modalidades de jornalismo participativo e cidadão (MANIOU; PANAGIOTIDIS; VEGLIS, 2019, p. 579). 


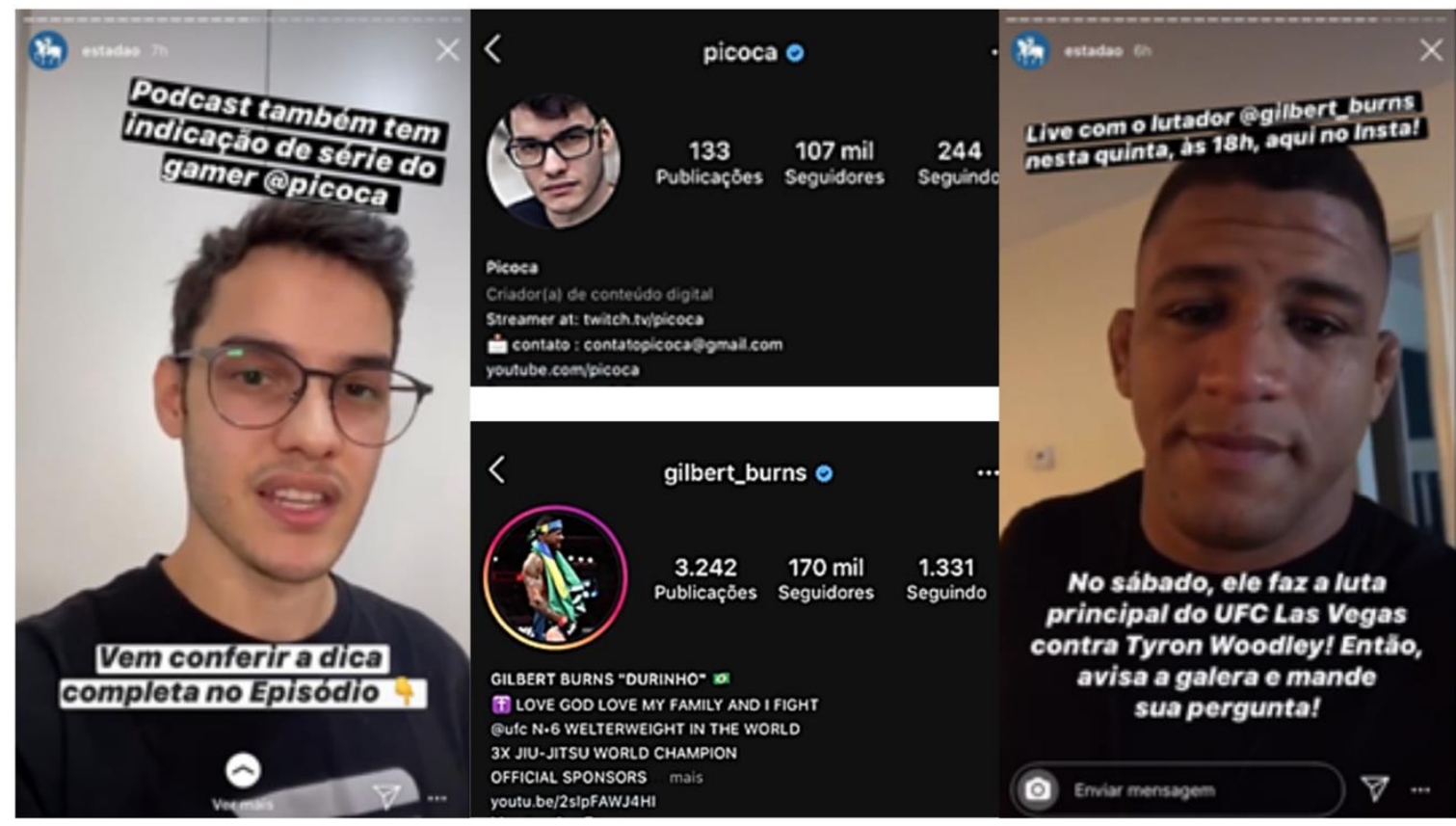

Fonte: captura de tela feita pela autora (2020)/ Reprodução Instagram

\subsubsection{A BUSCA PELA ATENÇÃO DOS USUÁRIOS NO INSTAGRAM}

Respondendo ao aumento do poder das plataformas, as organizações de notícias dobraram a produção de infotenimento e notícias de última hora, exatamente por entender que esse tipo de conteúdo gera um grande volume de tráfego de usuários aos sites dos jornais (VAN DIJCK; POELL; DE WALL, 2018). A produção e distribuição de tal conteúdo é especialmente orientada pelos dados da plataforma, a partir da análise dos assuntos que mais chamam a atenção da audiência.

Além da cobertura típica de hard news ${ }^{81}$, com as notícias urgentes, destacamse nos Stories a cobertura de assuntos do mundo do entretenimento tais como estilos musicais, lançamentos de séries e esportes (fig. 3.41 e 3.42). No caso do Estadão, esse conteúdo aparece com mais frequência ao final dos stories diários, principalmente às sextas.

81 Hard news é um jargão utilizado no jornalismo para temáticas relacionadas a questões mais duras como política, saúde, educação, segurança, infraestrutura pública, economia etc. Já Soft News é utilizado para classificar as notícias que possuem maior intuito de entreter e com maior apelo humano. 
Figuras 3.41 e 3.42 - Exemplos de soft news ligadas ao infotenimento nos Stories dos jornais

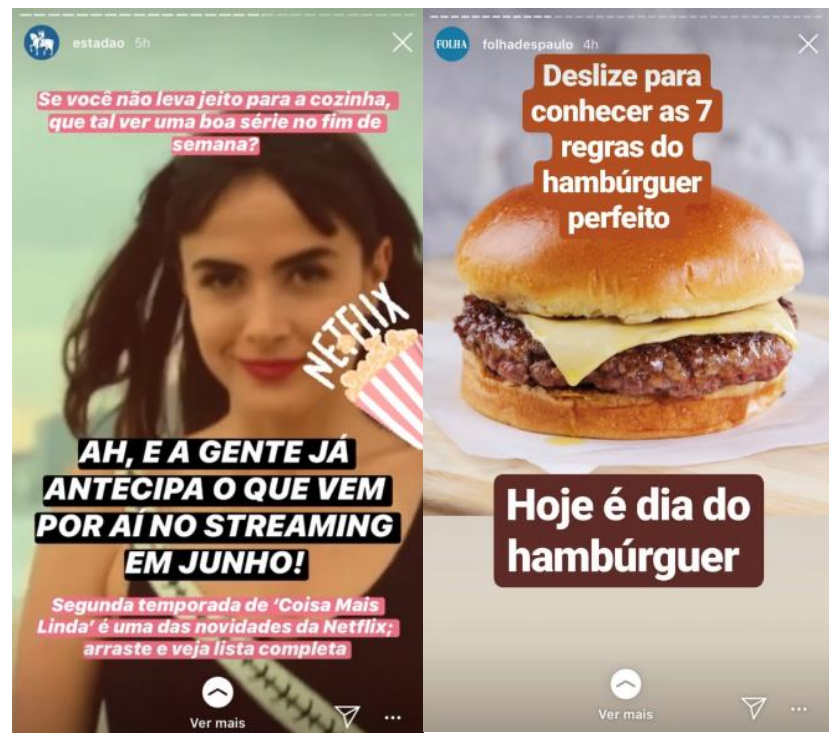

Fonte: captura de tela feita pela autora (2020)/ Reprodução Instagram

No ambiente dos Stories, essa abordagem temática também está intrinsecamente relacionada à valorização dos fãs, que desempenham um papel importante na cultura da convergência (JENKINS, 2009) ao criarem e compartilharem informações sobre suas produções midiáticas favoritas. O infotenimento presente nos Stories reforça o engajamento da audiência no perfil da empresa jornalística através da postagem com notícias para públicos mais segmentados, como o público nerd, e os fãs de estilos musicais como rock, funk ou pop (figuras 3.43 a 3.44).

Figuras 3.43 e 3.44 - Exemplos de soft news ligadas à cultura dos fãs.
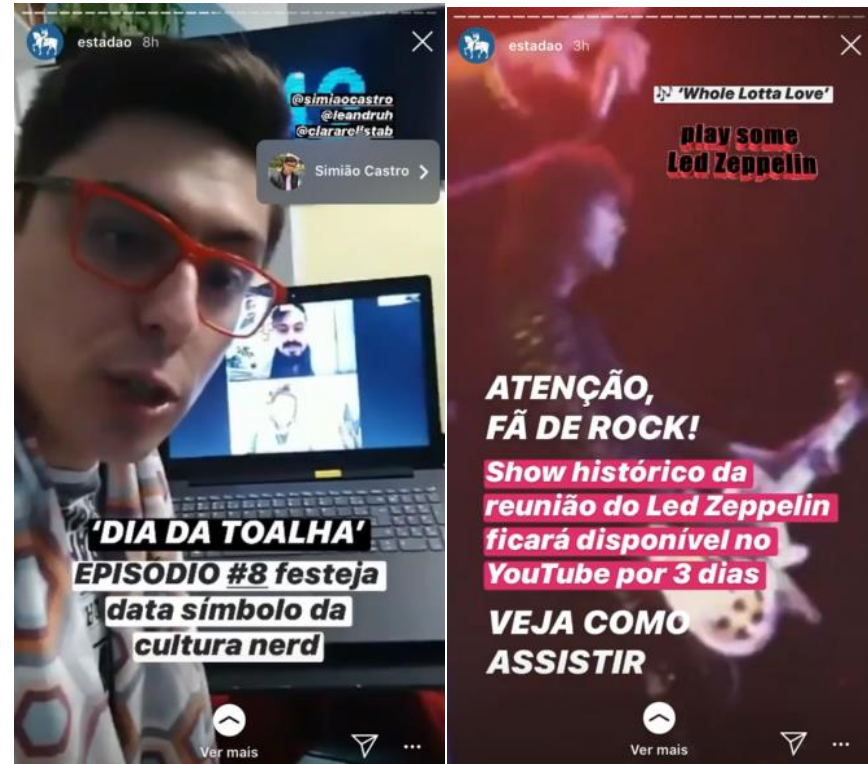

Fonte: captura de tela feita pela autora (2020)/ Reprodução Instagram 
Figuras 3.45 e 3.46 - Exemplos de soft news ligadas à cultura pop.

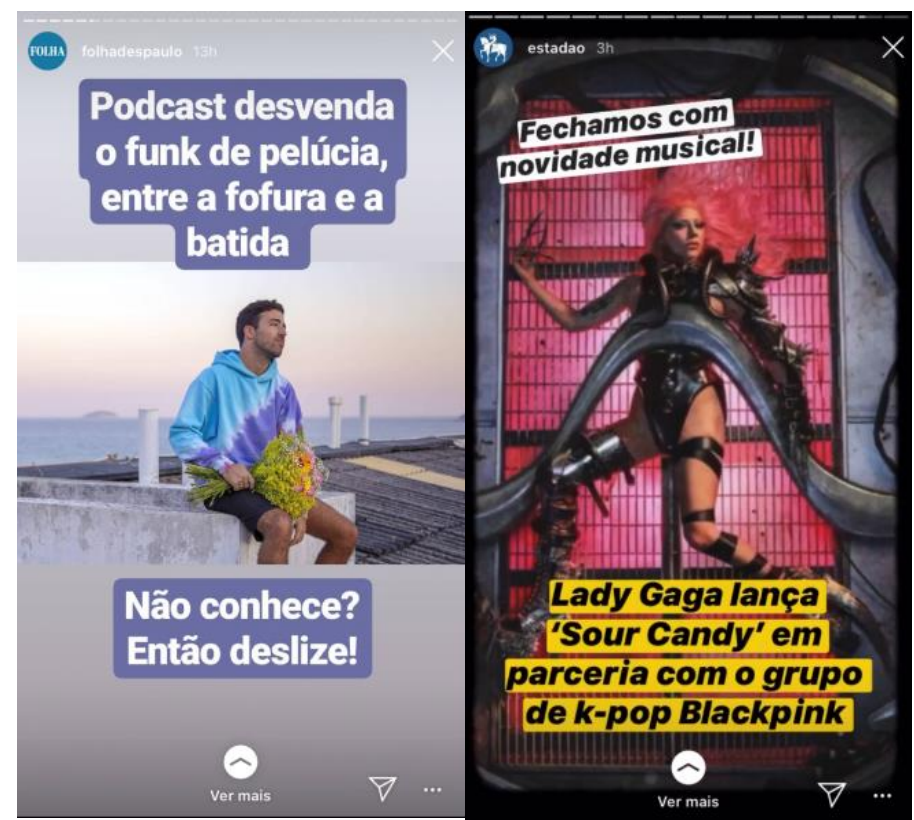

Fonte: captura de tela feita pela autora (2020)/ Reprodução Instagram

Ainda sobre as abordagens para entreter e chamar a atenção, os Stories possibilitam a exploração de narrativas que fogem do contexto do noticiário tradicional. Por meio de narrativas que aproximam a audiência do cotidiano dos jornalistas nos bastidores e em sua intimidade, as marcas jornalísticas fortalecem as imagens públicas dos apresentadores e também estreitam laços com o público.

$\mathrm{Na}$ semana analisada, o perfil oficial do Estadão repostou um vídeo do canal pessoal da jornalista Bárbara Pereira no qual ela ensinava o preparo de um bolo de cenoura enquanto aproveitava um dia de "folga" do trabalho (figuras 3.46 a 3.50).

Apesar de parecerem banais, temáticas como as apresentadas nesse tópico sobre entretenimento estimulam o envolvimento do público e a identificação das pessoas com a marca, justamente por mesclarem formatos diferentes, apelos emocionais e assuntos mais leves. 
Figuras 3.46 a 3.50 - Receita de bolo de cenoura publicada originalmente no perfil pessoal da jornalista @barbara_pereira e republicada pelo perfil oficial do Estadão
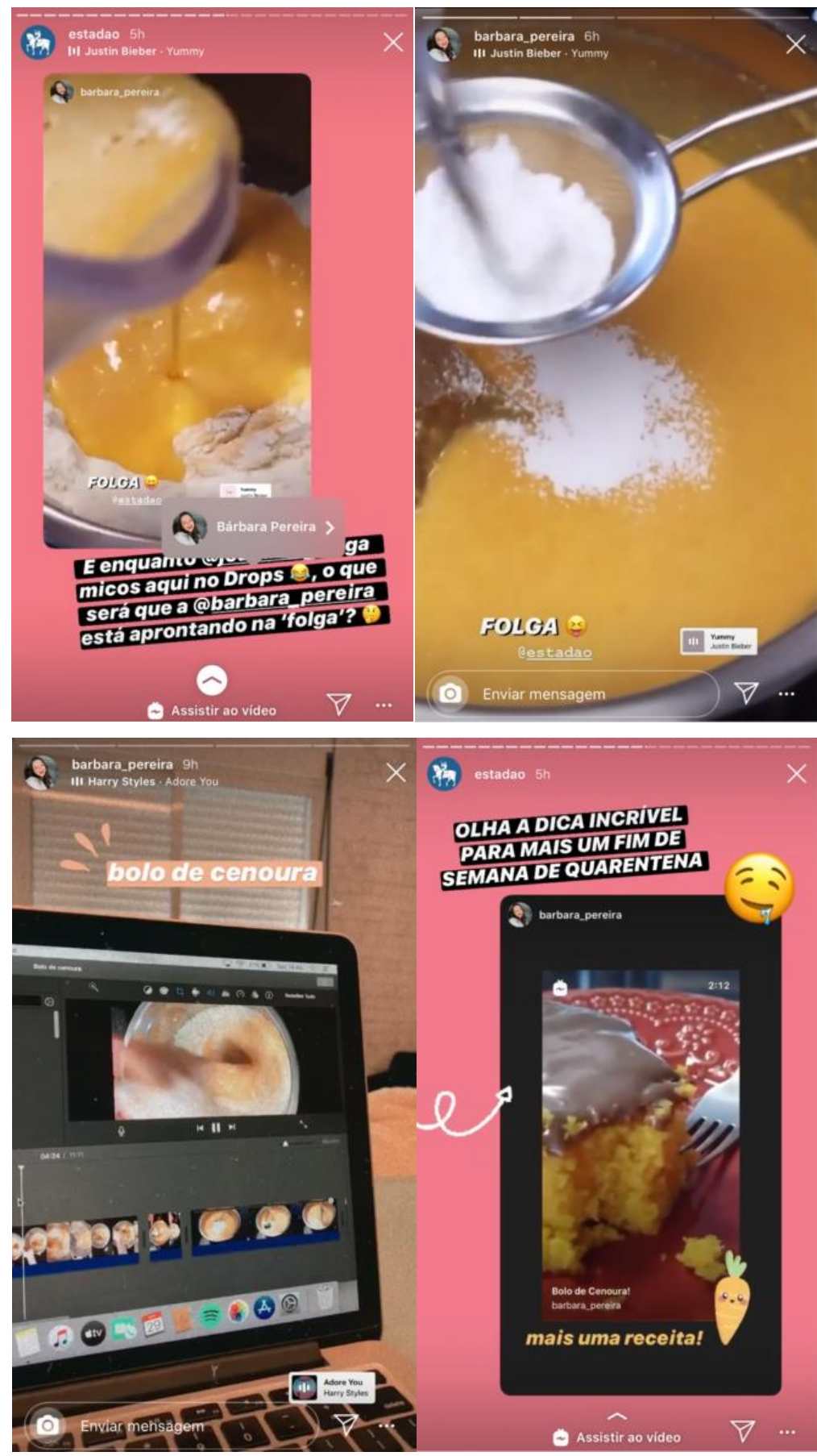

Fonte: captura de tela feita pela autora (2020)/ Reprodução Instagram

No próximo tópico aprofundaremos os valores narrativos dos Stories e a sua relevância para a produção jornalística, destacando o papel das emoções no jornalismo (BECKETT; DEUZE, 2016). 


\subsection{VALORES NARRATIVOS: A CONEXÃO EMOCIONAL PELOS STORIES}

Chegamos ao último conjunto do nosso diagrama, a estrutura de valores narrativos intrinsecamente ligada ao formato Stories e que, de maneira decisiva, influencia todos os outros componentes dessa mídia: os valores comerciais, os valores interativos e os valores audiovisuais.

Os Stories derivam de uma longa tradição audiovisual nos campos da arte, comunicação e tecnologia. Novas perspectivas e usos para o seu formato podem surgir com a observação de seus ancestrais a partir da comparação de familiaridades em suas interfaces. No primeiro capítulo, discutimos a questão das imagens e das comunicações principalmente a partir da imagem técnica (FLUSSER, 2018), momento em que acompanhamos a progressão de telas eletrônicas até a criação do smartphone. Agora, para pensar em seu potencial narrativo para a prática jornalística, gostaríamos de chamar ao palco uma mídia analógica que tem em seu DNA a estrutura sequencial baseada em quadros e que também une palavra e imagem para narrar: as histórias em quadrinhos, ou como popularmente são conhecidas, as HQs.

As HQs possuem um grande potencial para transformar a narração de histórias complexas em uma experiência imersiva mais acessível. Um exemplo disso pode ser visto através do historiador Yuval Harari, que se uniu ao escritor David Vandermeulen e ao ilustrador Daniel Casaneveautor para adaptar e lançar seu livro best-seller "Sapiens: Uma breve história da humanidade" no formato de uma graphic nove/82 para levar a ciência a mais pessoas.

Num livro de história acadêmico, você pode até contar uma piada, mas o tom geral tem que ser sério. Numa $\mathrm{HQ}$, há espaço para o humor. [...] Cientistas geralmente repetem números, fatos e estatísticas, mas a maioria das pessoas gostam de histórias. Então, tentamos contar histórias científicas. [...] Sou um novato no mundo das HQs e trabalhar em colaboração com o ilustrador me fez admirar a complexidade do formato. (HARARI, 2020, online)

É pertinente, inclusive, lembrarmos que os quadrinhos e o jornalismo possuem uma estreita ligação, já que foi através da publicação em jornais impressos, a partir do final do século XIX, que o gênero começou a circular nas cidades e a se popularizar entre as pessoas, ajudando, inclusive, a impulsionar as vendas de exemplares, o que contribuiu para a manutenção da atividade jornalística graças ao

82 Graphic novel é um tipo de história em quadrinho que apresenta uma narrativa completa, geralmente em formato de livro impresso. 
seu grande sucesso (CAMPOS, 2015). Com mais de 150 anos de história, Campos (2015) afirma que a linguagem e a estrutura das HQs modernas influenciaram outros formatos de narrativas na literatura, no teatro, no cinema, na televisão, nos vídeos games, nas artes plásticas e até no jornalismo. "Quando os primeiros cineastas pegaram suas primeiras câmeras, tinham na cabeça uma ideia de modo de narrar já bem desenvolvida pelos quadrinistas" (CAMPOS, 2015, p. 18). Enquadramento que se popularizaram nos filmes já eram usados nos quadrinhos no século XIX.

Também é consenso entre os pesquisadores que rastrear as origens dos quadrinhos e a sua "invenção" é praticamente impossível, uma vez que a gênese dos quadrinhos apresenta traços transnacionais e transculturais, fazendo com que nenhum país possa, de fato, reivindicar a propriedade dos quadrinhos (MAZUR; DANNER, 2014, p. 7).

\begin{abstract}
A propensão a contar histórias com figuras, combinando imagem e texto, parece universal: a Coluna de Trajano, pergaminhos asiáticos, tapeçarias medievais e retábulos, os jornais broadsheet do século XVIII e as gravuras japonesas feitas a partir de pranchas de maneira podem sem sombra de dúvida ser identificados como "pré-história" dos quadrinhos. (MAZUR; DANNER, 2014, p. 7).
\end{abstract}

Ao tentar nos aproximarmos de uma visão que explique essa tendência, encontramos Brunetti (2013), que relaciona a arte de quadrinizar ao impulso humano de desenhar de forma espontânea.

\footnotetext{
Rabiscamos para extravasar a raiva, aplacar a ansiedade ou o medo, nos divertir, mitigar a tristeza, expressar a frustração sexual, aliviar o tédio ou nos 'desligarmos' e fazermos elucubrações mentais. Todo rabisco, todo desenho, toda história tem uma base emocional. (BRUNETTI, 2013, p. 71)
}

Todos esses fatos evidenciam a relevância das narrativas em quadrinhos para a construção do imaginário das pessoas e também para a comunicação. Will Eisner, um dos precursores das graphic novels, foi um dos artistas que mais contribuíram para a volta da procura de quadrinhos pelo público adulto. Em seu livro sobre a "arte sequencial", o cartunista defende que os quadrinhos sejam levados "a sério" como formato capaz de levar informações por meio de técnicas que integram palavras e imagens para comunicar. "O rápido avanço da tecnologia de impressão e o surgimento de uma era em grande parte dependente da comunicação visual tornam isso inevitável" (EISNER, 2010, p. IX). 
Em sua expressão mais simples, os quadrinhos empregam uma série de imagens repetitivas e símbolos reconhecíveis. Quando são usados vezes e mais vezes para expressar ideias semelhantes, tornam-se linguagem [...]. E é essa aplicação disciplinada que cria a "gramática" da arte sequencial. (EISNER, 2010, p. 2).

Como lembra Eisner, é possível criar toda uma história apenas através de imagens. A tipografia das letras também é capaz de transmitir emoção e as imagens e palavras, quando colocadas de certas maneiras, podem inclusive passar a ideia de som aos quadrinhos. "A codificação, nas mãos do artista, transforma-se num alfabeto que servirá para expressar certo contexto, tecendo toda uma trama de interação emocional" (EISNER, 2010, p. 10).

Transpondo os ensinamentos de Eisner para a "gramática" dos Stories, observamos que, a depender do enquadramento e do uso específico de uma imagem, por meio do repertório do próprio leitor, é possível "invocar uma nuance de emoção e dar inflexão audível à voz falante" (2010, p. 106). Na figura 3.51, por exemplo, reconhecemos essa propriedade no uso da fotografia de Jair Bolsonaro com a boca aberta e os "balões de fala" próximos a ela. Pela sua expressão facial, conota-se um sentimento de raiva e de exaltação. O rosto é um terreno familiar para a maioria das pessoas. Nele somos capazes de ler emoções com facilidade, mesmo que não estejam explicitamente mostradas no texto, pois o "rosto também dá sentido à palavra escrita" (EISNER, 2010, p. 114).

\section{Figura 3.51 - Exaltação emocional no rosto de Bolsonaro acrescenta informação ao texto}
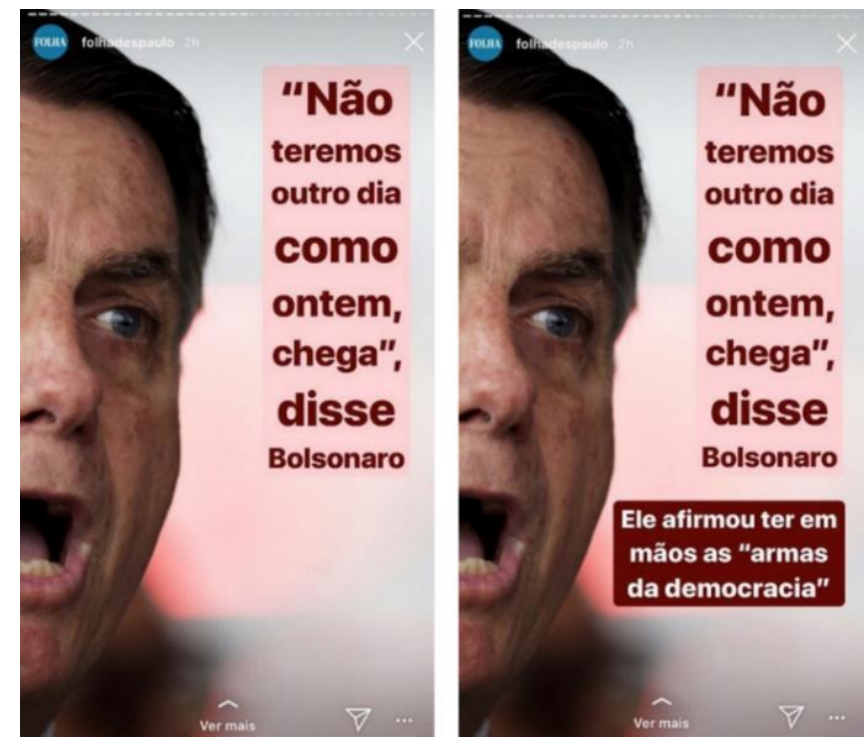

Fonte: captura de tela feita pela autora (2020)/ Reprodução Instagram Stories da Folha 
Além das técnicas de arte sequencial que podem ser apropriadas das HQs, os Stories também permitem a construção de histórias seguindo padrões narrativos, muito utilizados pelo teatro e pela literatura. Um dos mais conhecidos é o arco narrativo, criado em 1863, pelo dramaturgo e romancista alemão Gustav Freytag, que divide as obras dramáticas em cinco fases: exposição, aumento da ação, clímax, declínio da ação e conclusão (ou desfecho). De forma mais simples, o arco pode ser resumido "no padrão início/meio/fim" (LUPTON, 2020, p. 24).

Um conjunto de três stories capaz de exemplificar uma adaptação do conceito de arco narrativo para o formato é o que aparece na figura 3.25. Para quem estivesse com o som habilitado, a trilha sonora era de rock progressivo. No primeiro, a ação é apresentada com uma chamada textual sobre a "Operação Placebo". Nessa cena, o Estadão utilizou imagens aéreas e uma etiqueta de localização, intensificando a sensação de imersão na história. Em seguida, o story do meio mostra a movimentação de carros e policiais chegando ao local, com a revelação de que "computadores e celulares" do então governador do Rio de Janeiro, Wilson Witzel, foram apreendidos na ação. O desfecho, sobre os "indícios de desvios de recursos públicos", aparece no terceiro story em conjunto com uma pergunta para despertar a curiosidade do leitor a continuar lendo sobre a notícia no site do jornal.

Figura 3.52 - Cenas da Operação Placebo com começo, meio e fim.
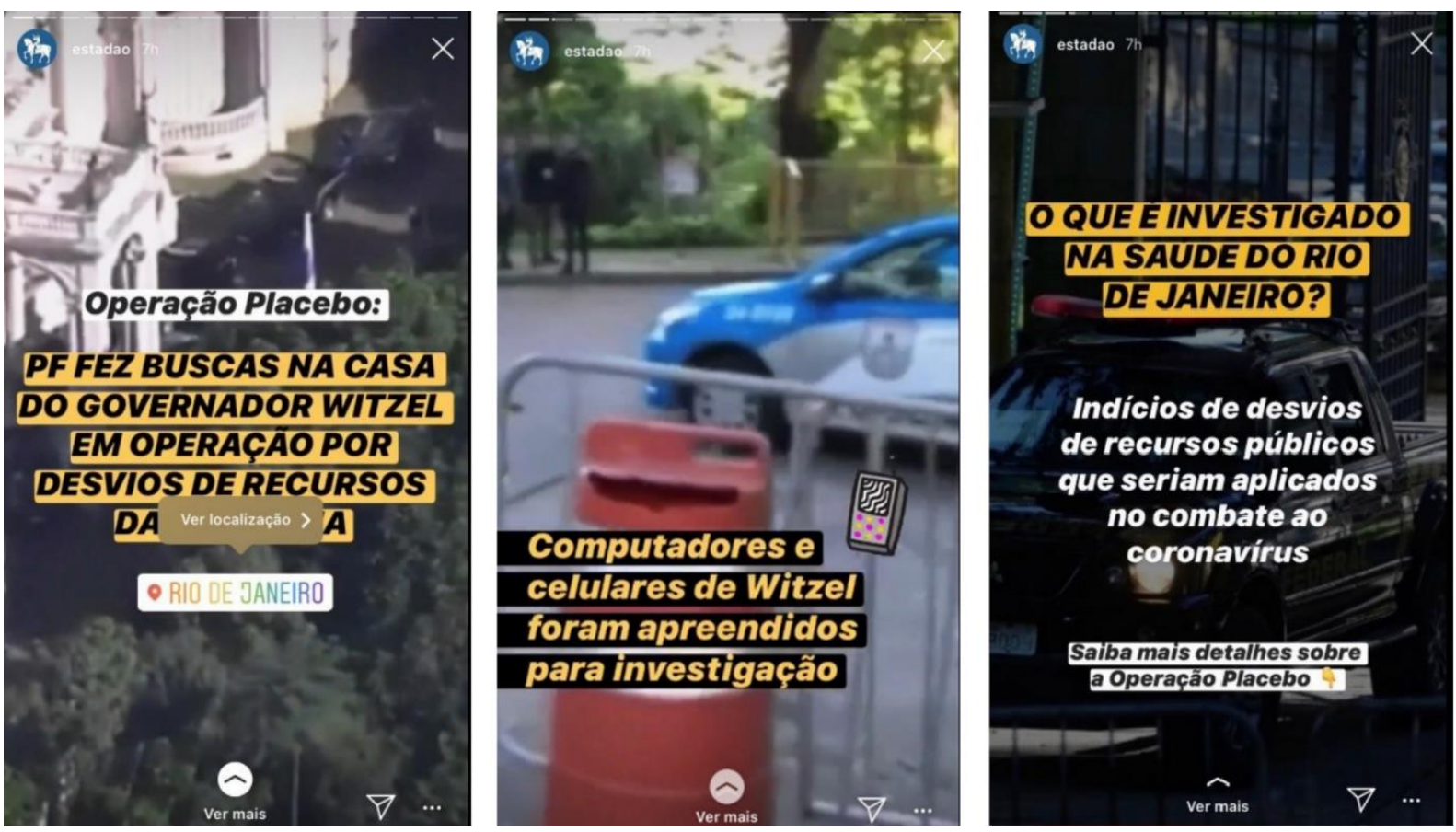

Fonte: captura de tela feita pela autora (2020)/ Reprodução Instagram 
Ellen Lupton (2020) pesquisadora que estuda as conexões entre storytelling e design, afirma que "o design de qualquer coisa, desde instruções de passo a passo até uma manchete atraente [...] pode iniciar uma curva dramática que vai do baixo ao alto, do desejo à satisfação" (LUPTON, p. 24) Essa sensação de satisfação viria, segundo a autora, através do senso de conclusão da história.

\subsubsection{O PAPEL DO DESIGN NOS STORIES PARA A ATIVAÇÃO DE EMOÇÕES}

Para Ramirez (2019), faz sentido pensar que os leitores de notícia demandem conteúdos mais elaborados e com estratégias de design multissensoriais, visto que "estão se tornando cada vez mais alfabetizados em narrativas multimídia" (RAMIREZ, 2019, online) ao serem expostos constantemente a mídias como os Stories. A facilitação do acesso às ferramentas de criação e edição de imagens dentro dos Stories possibilita que o público em geral atue potencialmente como designers visuais (RAMIREZ, 2019).

De acordo com Lupton (2020), o trabalho dos designers é capaz de mobilizar as emoções das pessoas, desencadeando sentimentos como os de prazer ou confiança, além de incorporar valores e ilustrar ideias em suas criações. Para a especialista, tanto as histórias como o processo de design conseguem mover as pessoas e contribuir para o processo de comunicação.

\footnotetext{
A palavra 'ação' está no cerne da 'interação'. 'Design' é verbo, além de substantivo. [...] Assim como uma história envolvente, um produto, imagem ou local bem projetado se desenrola ao longo do tempo. Ajuda a criar memórias e estabelecer conexões. Contém personagens, objetivos, conflitos e vívidos cenários sensoriais. (LUPTON, 2020, p. 21)
}

O jornalista, com isso, necessita se aproximar cada vez mais do design para entender e conhecer modos de ativar as emoções nos leitores. A pesquisadora da área de comunicação, Daniela Bertocchi (2016), que estuda a construção de narrativas no jornalismo digital, coloca o jornalista como um "designer de experiência narrativa, como um profissional que tem protagonismo na modelagem do sistema narrativo, contribuindo com insumos ao longo de todo o processo" (BERTOCCHI, 2016, p. 72).

Isso nos leva a enxergar a profissão do jornalista além das tradicionais etapas de apuração e de produção do texto jornalístico, entendendo globalmente toda a 
cadeia produtiva, não apenas até a chegada do conteúdo à audiência, mas também em sua recepção e reverberação.

Beckett e Deuze (2016) pontuam que a tendência dos meios de comunicação de se tornarem cada vez mais móveis, personalizados e movidos por emoções colocam um desafio claro para o jornalismo: "encontrar a melhor forma de sustentar o valor ético, social e econômico do jornalismo neste novo ambiente emocionalmente conectado" (BECKETT; DEUZE, 2016, p. 5, tradução nossa ${ }^{83}$ ).

De acordo com algumas das mais recentes descobertas da neurociência, informações que carregam conteúdo com alta carga emocional e provocativa têm maior chance de permanecerem em nossas mentes e serem incorporadas a bancos de memória de longo prazo (BARR, 2019).

A indústria de fake news utiliza as estratégias ligadas ao nosso desejo inato de ser bem informado para nos manipular e chamar a nossa atenção.

\begin{abstract}
Em um mundo cheio de surpresas, os humanos desenvolveram uma habilidade requintada de detectar e se orientar rapidamente em relação a informações ou eventos inesperados. A novidade é um conceito essencial subjacente à base neural do comportamento e desempenha um papel em quase todos os estágios do processamento neural. [...] A própria novidade está relacionada à motivação. A dopamina, um neurotransmissor associado à antecipação de recompensas, aumenta quando somos confrontados com novidades. Quando vemos algo novo, reconhecemos seu potencial para nos recompensar de alguma forma. Estudos demonstraram que a capacidade do hipocampo de criar novas conexões sinápticas entre os neurônios (um processo conhecido como plasticidade) é aumentada pela influência da novidade. Ao aumentar a plasticidade do cérebro, o potencial para aprender novos conceitos também é aumentado. (BARR, 2019, online, tradução nossa) ${ }^{84}$
\end{abstract}

Segundo Barr (2019), o mero fato de sermos expostos a uma manchete de notícia falsa pode aumentar a crença posterior nessa manchete. Com o uso crescente das mídias sociais carregadas de conteúdo altamente emocional, também cresce o acesso das pessoas a esse tipo de publicação, visto que a desinformação ainda é um problema a ser superado.

83 "The challenge for the networked journalist is clear: how best to sustain the ethical, social, and economic value of journalism in this new emotionally networked environment."

84 "In a world full of surprises, humans have developed an exquisite ability to rapidly detect and orient towards unexpected information or events. Novelty is an essential concept underlying the neural basis of behavior, and plays a role at nearly all stages of neural processing. [...] Novelty itself is related to motivation. Dopamine, a neurotransmitter associated with reward anticipation, increases when we are confronted by novelty. When we see something new, we recognize its potential to reward us in some way. Studies have shown that the hippocampus' ability to create new synaptic connections between neurons (a process known as plasticity) is increased by the influence of novelty. By increasing the brain's plasticity, the potential to learn new concepts is also increased." 
Retomando a história do repórter Alex Zdan e a sua reação inesperada dirigida ao eleitor de Trump durante uma transmissão ao vivo na TV, contada no tópico 1.2.1, conseguimos entender que estamos cada vez mais distantes da ideia de que o jornalismo é uma instituição rígida e imutável. Ao contrário, o exemplo da repercussão positiva de sua atitude entre a audiência nas redes sociais nos incentiva a refletir sobre as mudanças na área.

Para Beckett e Deuze (2013), esse fenômeno é uma consequência do desejo que as pessoas expressam em ver no jornalismo histórias que contenham toda uma gama de emoções (como amor e desejo, espanto e surpresa, diversão, raiva e medo), assim como narrativas confiáveis e com um propósito claro.

A confiabilidade na era do jornalismo em rede é cada vez mais determinada por sua autenticidade emocional. Esse jornalismo tem o fator humano em seu centro, até porque o público agora faz parte do processo. (BECKETT; DEUZE, 2016, p. 4-5)

À medida que essas mudanças avançam no cenário de mídias, conseguimos observar o surgimento de novos estilos de narrativas e formatos jornalísticos, como os Stories aqui apresentados, capazes de integrar vozes locais de comunidades, relatos pessoais ou narrativas visuais com um estilo mais informal, fugindo das fórmulas tradicionais de construção das notícias.

Deuze (2019), ao avaliar o panorama atual da comunicação, acredita que não será a indústria de notícias que "salvará" o jornalismo da crise ou que o fará encontrar a sua "essência". Para o pesquisador, o que de fato garantirá que o jornalismo permaneça relevante para a vida das pessoas é a atuação dos próprios profissionais, isto é, aqueles que o exercem, através de uma conexão cognitiva e afetiva com o campo. 85

[...] o que explica o "jornalismo" são os laços afetivos e cognitivos que os profissionais (ou seja, aqueles que ganham a vida com isso e se orgulham de sua atuação, o que lhes dá algum senso de propriedade sobre sua identidade de trabalho) vinculam a ele (Beckett \& Deuze, 2016). Os jornalistas se preocupam com seu trabalho, muitas vezes amam o que fazem (e por que 0

85 " [...] what explains "journalism" are the affective and cognitive ties that professionals (i.e., those who earn their living from it and take pride in their craftsmanship of it, which gives them some sense of ownership over their professional identity) bind to it (Beckett \& Deuze, 2016). Journalists care about their work, often love what they do (and why they are doing it), and this translates into a particular perspective on what journalism is and should be. 
fazem), e isso se traduz em uma perspectiva particular sobre o que é o jornalismo e o que deveria ser. [...] (DEUZE, 2019, p. 3)

A chave para combater as fake news e restabelecer a confiança do público na imprensa passa pela necessidade de pautar a subjetividade humana, reconhecendo as emoções, na expressão de maneira transparente desse aspecto no ecossistema de notícias, conforme sugerem Beckett e Deuze (2016):

\begin{abstract}
Uma maneira de colocar a emoção em primeiro plano no jornalismo em rede de hoje de maneira profissional e com princípios é por meio da transparência. Transparência é a moeda de troca e validação para um ecossistema de notícias afetivas, e argumentamos que tem o potencial de evitar a armadilha de um jornalismo de emoção ser acusado de simples subjetividade e preconceito. A abertura, incluindo a abertura ao papel central da emoção em conectar o conteúdo aos produtores e ao público, será a força animadora na era conectada das mídias sociais. (BECKETT; DEUZE, 2016, p. 4-5, tradução nossa $\left.{ }^{86}\right)$
\end{abstract}

Dessa forma, também entendemos ser importante ter um olhar para além dos aspectos sociais, culturais, históricos ou políticos das pessoas, a fim de também contemplar aspectos psicológicos e neurobiológicos para entender como as narrativas podem influenciar a própria química do corpo humano.

Já se sabe que, na raiz do processo da criação de confiança, está a liberação de ocitocina, um hormônio produzido pelo hipotálamo relacionado ao bem-estar (Kosfeld et al, 2005). Ainda no mesmo campo, neurocientistas descobriram que histórias que são mais pessoais e mais emocionais são capazes de engajar mais 0 cérebro e, assim, serem mais lembradas do que fatos contados aleatoriamente (Glaser et al., 2009; Hong; Lin-Siegler, 2012).

Apesar da importância das histórias em nosso cotidiano, a neurociência da narrativa só recentemente começou a ser uma área de pesquisa ativa Martinez-Conde et al, 2019). Já se sabe, porém, que parte do prazer que sentimos com as narrativas está em seu potencial de evocar imagens mentais:

Não apenas processamos as palavras e frases em uma página, mas podemos experimentar o que acontece na história de forma vívida, simulando mentalmente o conteúdo de uma narrativa. Podemos ver o que está sendo

86 "A way to put emotion front and center in today's networked journalism in a principled and professional manner is through transparency. Transparency is the trading and validating currency for an affective news ecosystem, and we argue it has the potential to prevent the pitfall of a journalism of emotion to be accused of simple subjectivity and bias. Openness, including openness to the central role of emotion in connecting content to producers and the public will be the animating force in the connected age of social media". 
descrito, e até mesmo sentir o que os personagens sentem, usando nossas próprias mentes para viver o mundo da ficção. (Martinez-Conde et al, 2019, p. 8287, tradução nossa ${ }^{87}$ )

Para pensar em um ecossistema de comunicação que ative o potencial das narrativas, é preciso integrar não apenas os jornalistas, mas também o entorno, pois o sistema narrativo demanda uma visão holística de todo o processo (BERTOCCHI, 2016). Os levantes populares que tomaram conta das notícias na semana analisada - um processo que se estende desde o início da Primavera Árabe - destacam o papel decisivo da participação efetiva do público no processo narrativo.

Com o propósito de ter um olhar mais humano, o jornalismo precisa olhar diretamente para as pessoas e não apenas para os números de audiência construídos por meio de algoritmos em no mundo cada vez mais cercado de big data. Para ultrapassar a bolha algorítmica (PARISER, 2012) e chegar às pessoas, o jornalista também terá que intensificar a sua competência como comunicador-curador (SAAD CORRÊA; BERTOCCHI, 2012) de informações, através de competências já exercidas, porém ainda mais exigidas devido à abundância informativa, tais como "seleção, filtragem, agregação e, mais importante, remediação de conteúdos para partilha em rede, inclusive com auxílio de algoritmos" (SAAD CORREAA; BERTOCCHI, 2012, p. 1).

Para Deuze (2019), a grande preocupação do campo jornalístico está em encontrar maneiras de treinar e capacitar toda e qualquer pessoa a pensar e a agir como um jornalista em potencial, ou seja, capaz de verificar rigorosamente informações através de múltiplas fontes, de buscar diferentes pontos de vista e de dominar a arte de contar histórias que sejam importantes para a vida das pessoas.

Uma das sugestões do pesquisador é o investimento em pesquisas na comunicação e em alfabetização midiática para incentivar o pensamento crítico e criativo. Outra maneira de colaborar para esse processo é o entendimento da atuação do jornalista como designer de experiências narrativas (BERTOCCHI, 2016), que filtra, edita, formata e apresenta informações de uma maneira relevante para a vida das pessoas.

87 " $P$ art of the pleasure that we derive from engaging with narratives lies in their potential to evoke mental images. We do not just process the words and sentence on a page, but we can experience what happens in the story in a vivid manner, by mentally simulating the content of a narrative. We can see what is being described, and even feel what the characters feel, using our own minds to live the fiction world." 
Com isso, podemos conceber um presente (e um futuro) em que os Stories sirvam como um ambiente de trocas contínuas entre o jornalismo e as diversas vozes presentes nos contextos locais. 


\section{CONCLUSÃO}

Rastreamos em nossa pesquisa algumas das principais estratégias de divulgação de conteúdo jornalístico nos Stories da Folha e do Estadão no Instagram. A fim de levar esse procedimento para um universo comunicacional mais amplo, também trouxemos discussões sobre valores coexistentes dentro do espaço midiático dos Stories que influenciam a prática jornalística nesse contexto. A partir da observação da estrutura dos elementos que juntos formam os stories jornalísticos, conseguimos descrever o protagonismo de alguns valores que são reforçados pela plataforma: valores interativos, valores comerciais, valores audiovisuais e valores narrativos. Pela grande complexidade do tema, assumimos que esse é um estudo preliminar e de caráter introdutório, que pede a sua continuidade e a sua complementaridade através da análise e da investigação também a partir de outras pesquisas.

As características temporais e espaciais dos Stories podem nos levar a imaginar que se trata de uma mídia superficial (como se informar com profundidade em 15 segundos?) e aparentemente descartável (qual a razão de produzir conteúdo para essa mídia se em 24 horas ninguém mais conseguirá acessá-lo?). Em nossa análise de conteúdo, apresentada no segundo capítulo, percebemos que o Estadão e a Folha esforçam-se para contornar esses "supostos obstáculos" apresentados pelo formato justamente aproveitando sua versatilidade e temporalidade. As empresas oferecem uma seleção de conteúdos com os assuntos mais relevantes e atrativos do momento, de modo que a audiência possa encontrar o aprofundamento de acordo com seus gostos e preferências em outras mídias, a partir de fontes internas ou externas aos jornais.

O papel curador do jornalismo é um fenômeno já observado em outras mídias, mas, nos Stories, encontramos algumas especificidades. Ele se comporta como um espaço multimídia interativo para a distribuição de conteúdo informativo. Tal qual numa vitrine, é possível localizar nas publicações diárias os destaques da cobertura midiática e, posteriormente, escolher se aprofundar ou não sobre o que for mostrado. Dentro da plataforma, o usuário atua como protagonista e possui autonomia para se guiar pelos caminhos disponíveis. Pode criar e recriar identidades dentro de seu perfil pessoal e as opções de interatividade passam a sensação de estar no controle. Mas 
existe uma limitação muitas vezes invisível para aqueles que estão nesse ambiente: as regras algorítmicas definidas pelos donos do negócio.

A onda de exposição das fragilidades das plataformas vem aumentando cada vez mais a desconfiança do público e dos anunciantes com relação às empresas de tecnologia. Para melhorar o relacionamento com as plataformas digitais, o caminho pode estar justamente na transparência e na pressão social e política a partir de aspectos econômicos e de regulamentação do mercado. Além disso, ao contrário do que se pensava - que as plataformas de mídias sociais estão "engolindo" a atividade jornalística - acreditamos que, apesar dos problemas a serem superados, elas oferecem um terreno fértil para a exploração de recursos visuais na construção de narrativas jornalísticas, já que é possível criar desde experiências mais cinematográficas até formatos mais simples, como memes e gifs.

Atentos às mudanças, outros produtores de conteúdo e empresas do setor de comunicação tentam se adequar ao contexto tecnológico e sociocultural, já que o surgimento de novas mídias costuma provocar alterações no ecossistema midiático. Uma amostra de como o formato Stories reconfigurou o cenário de mídias é o fato de que diversas outras plataformas digitais também incorporaram modelos semelhantes em suas estruturas: Facebook, Twitter, Linkedln, YouTube, Netflix...

Ainda vivemos em mundo que passa por uma pandemia com o novo coronavírus, temos diversas democracias que estão passando por sérios abalos e a crise climática global bate à nossa porta devido à destruição incessante da natureza. O avanço da desinformação coloca todas essas questões em discussão com o apoio de negacionistas. Apesar disso, os dados apresentados nessa dissertação mostram que as futuras gerações possuem condições de aprender a administrar a avalanche de informações para identificar com mais facilidade o que é falso do que é verdadeiro ${ }^{88}$. Para que isso aconteça, antes de pensar no jornalismo do futuro, é preciso transformar o jornalismo feito no presente para posteriormente colher os frutos dessa semeadura. Composto por estruturas muito mais flexíveis, instáveis e dinâmicas (e precárias), o trabalho do jornalista no século XXI se difere drasticamente do trabalho feito pelo profissional da notícia na época em que apenas as ondas do rádio e as páginas do jornal impresso imperavam. Apesar disso, vimos que algumas

88 Sem entrar no mérito filosófico da definição do conceito de Verdade, recorremos a "uma noção comum de que notícia verdadeira é aquela que corresponde aos fatos, que pode ser verificada ou provada, e que está escorada por outras certezas" (CHRISTOFOLETTI, 2019, p. 55). 
semelhanças entre as duas atuações persistem e podem, inclusive, nos oferecer respostas sobre o jornalismo do futuro. Dessa forma, é fundamental conhecer e entender os formatos de mídia que estão em alta entre as pessoas.

Por fim, tendo em mente que a negação das emoções no ambiente jornalístico não é sinônimo de objetividade ou imparcialidade, compreendemos que os Stories se mostram como um forte aliado para que essa questão seja desmistificada. Negar a influência das emoções sobre o comportamento das pessoas contribui para a falsa ilusão de que o jornalismo não inclui o viés de quem o produz. Saber que um produto jornalístico possui um ponto de vista não tira o valor da apuração de um fato e isso pode ser apresentado pelos próprios jornalistas ao compartilharem os bastidores das notícias com o público nos Stories. Essa postura adiciona valor à informação e empodera quem a consome, justamente por reforçar a ideia de que é necessário ter um olhar crítico para os conteúdos que circulam nas plataformas digitais e para a produção jornalística como um todo.

Assim, após explorar as potencialidades dos Stories para o jornalismo, finalizamos ressaltando a importância da transparência nas relações entre jornalistas e sociedade. Levando em conta o grande público que consome informações jornalísticas pelo Instagram Stories, incentivamos a educação midiática dentro desse universo como uma das maneiras de esclarecer a distinção entre opiniões e fatos, e entre notícias e desinformação. 


\section{REFERÊNCIAS}

AGUIAR, T. Felipe Neto é novamente alvo de boato falso que o associa à pedofilia. 27 jul. 2020. Disponível em: https://politica.estadao.com.br/blogs/estadao-verifica/felipe-neto-e-novamente-alvo-deboato-falso-que-o-associa-a-pedofilia/ Acesso em: 19 set. 2020.

ALDAMA, Frederick Luis. The Science of Storytelling: Perspectives from Cognitive Science, Neuroscience, and the Humanities. Projections, v. 9, n. 1, p. 80, 2015.

ALVES, Y. M. Jornalismo em mídias sociais de imagens instantâneas: as narrativas jornalísticas em formato de stories no Snapchat e Instagram. Orientadora: Edna de Mello Silva. 2018. 167 f. Dissertação (Mestrado em Comunicação e Sociedade) - Universidade Federal do Tocantins, Palmas, 2018.

ANDREASSA, L. O que é polarização e por que é prejudicial à democracia? 30 jul 2020. Disponível em: https://www.politize.com.br/o-que-e-polarizacao/ Acesso em: 16 nov 2020.

ASSIS, I. P.; BETTI, J. G.; GOBBI, M. C. Efemeridade e permanência: a tecnologia na construção de uma memória jornalística. RAZÓN Y PALABRA, v. 21, p. 346-360, 2017.

BAITELLO JUNIOR, N. A Era da Iconofagia: Reflexões sobre imagem, comunicação, mídia e Cultura. São Paulo: Paulus, 2014.

BARR, R. Galaxy brain: The neuroscience of how fake news grabs our attention, produces false memories, and appeals to our emotions. Nov 2019. https://www.niemanlab.org/2019/11/galaxy-brainthe-neuroscience-of-how-fake-news-grabs-our-attention-produces-false-memories-and-appeals-toour-emotions/ Acesso em 15 nov. 2020.

BARROS, L. S. Narrativas efêmeras do cotidiano: um estudo das stories no Snapchat e no Instagram. Orientador: Alex Fernando Teixeira Primo. 2017. 208 f. Dissertação (Mestrado em Comunicação e Informação) - Universidade Federal do Rio Grande do Sul, Porto Alegre, 2017.

BAUMAN, Z. Modernidade Líquida. Rio de Janeiro: Zahar, 2001.

BAYER, J. B.; ELLISON, N.; SCHOENEBECK, S. Y.; FALK, E. B. Sharing the Small Moments: Ephemeral Social Interaction on Snapchat. In: Information Communication and Society, 2016. Disponível em: https://doi.org/10.1080/1369118X.2015.1084349 . Acesso em: 10 jan. 2018.

BECKETT, C.; DEUZE. M. On the Role of Emotion in the Future of Journalism. Social Media + Society, Jul 2016. Disponível em: https://doi.org/10.1177/2056305116662395.

BERTOCCHI, D. D. Dados aos formatos: a construção de narrativas no jornalismo digital. 1. ed. Curitiba: Appris 2016. 
BERTOCCHI, Daniela. A Narrativa Jornalística no Ciberespaço: transformações, conceitos e questões. Departamento de Ciências da Comunicação, Universidade do Minho, Braga, 2006.

GARTSBEYN, M. Remembering Betty Sushman, the elderly woman who 'lived in the moment' in viral photo. Maio 2018. Disponível em: https://www.boston.com/news/obituaries/2018/05/31/obituary-bettysushman-living-in-the-moment-viral-black-mass-photo Acesso em 8 dez 2019.

BORGES, A. Blog: uma ferramenta para o jornalismo. In: FERRARI, P. Hipertexto, hipermídia: as novas ferramentas da comunicação digital. São Paulo: Contexto, 2016.

BRADSHAW, Paul. Snapchat for Journalists. Leanpub, 2016. Disponível em: https://leanpub.com/snapchatforjournalists/. Acesso em: 20 mai. 2017.

BRIDGER, D. Neuromarketing: como a neurociência aliada ao design pode aumentar o engajamento e a influência sobre os consumidores. 1. ed.; 3. reimp. São Paulo: Autêntica Business, 2020.

BROOKER, C. Charlie Brooker: the dark side of our gadget addiction. dez 2011. Disponível em: https://www.theguardian.com/technology/2011/dec/01/charlie-brooker-dark-side-gadget-addictionblack-mirror Acesso em: 12 out 2020.

BRUNER, J. A interpretação narrativa da realidade. In: A cultura da educação. Porto Alegre: Artmed, 2001.

BRUNER, J. Realidade mental, mundos possíveis. 2. ed. Porto Alegre: Artes Médica, 2002.

BRUNETTI, I. A arte de quadrinizar : filosofia e prática. São Paulo: WMF Martins Fontes, 2013.

BULKELEY, William M. Ten Breakthrough Technologies. MIT Technology Review, mai./jun. 2010. Disponível em: http://www2.technologyreview.com/article/418541/tr10-social-tv\&gt;. Acesso em: 21 abr. 2012.

CAMILLO, M. (2018). Jornalista da Folha lança manual com dicas para produção de conteúdo no Instagram Stories. Disponível em: https://novoemfolha.blogfolha.uol.com.br/2018/04/25/jornalista-dafolha-lanca-manual-com-dicas-para-producao-de-conteudo-no-instagram-stories/. Acesso em: 30 abr. 2018

CAMILLO, M. Conheça o 'Não Durma Sem Saber', o resumo de notícias diário do Instagram da Folha. Folha de São Paulo, São Paulo, 14 de jan. de 2019. Poder. Disponível em: https://www1.folha.uol.com.br/poder/2019/01/conheca-o-nao-durma-sem-saber-o-resumo-de-noticiasdiario-do-instagram-da-folha.shtml. Acesso em: 15 de agosto de 2020.

CAMILLO, M. Por que o chinês TikTok bombou e incomoda Trump e Zuckerberg. 25 jul 2020. Disponível em: https://www1.folha.uol.com.br/ilustrissima/2020/07/por-que-o-chines-tiktok-bombou-e-incomodatrump-e-zuckerberg.shtml Acesso em 16 nov 2020. 
CAMPOS, R. Imageria: o nascimento das histórias em quadrinhos. São Paulo: Veneta, 2015.

CASTELLS, M. A sociedade em rede. São Paulo: Paz e Terra, 1999.

CASTELLS, Manuel. Redes de indignação e esperança: movimentos sociais na era da internet. Rio de Janeiro: Zahar, 2013

CHAKRABORTY et al. "Stop Clickbait: Detecting and prevent clickbaits in online news media", 2016 IEEE / ACM International Conference on Advances in Social Networks Analysis and Mining (ASONAM) , São Francisco , CA, 2016, p. 9-16, doi: 10.1109 / ASONAM.2016.7752207.

CHRISTOFOLETTI, R. A crise do jornalismo tem solução?. Barueri, SP: Estação das Letras e cores, 2019.

COULDRY, N.; MEJIAS, U. A. The costs of connection: How data is colonizing human life and appropriating it for capitalism. Stanford, CA: Stanford University Press, 2019.

COULDRY, N.; YU, J. Deconstructing datafication's brave new world. new media \& society 1-19, 2018. Disponível em https://doi.org/10.1177/1461444818775968. Acesso em: 15 ago. 2020.

DEJAVITE, F. A. A Notícia light e o jornalismo de infotenimento. Trabalho apresentado no VI Encontro de Núcleo de Pesquisa - NP - Jornalismo. XXX CONGRESSO BRASILEIRO DE CIÊNCIAS DA COMUNICAÇÃO, promovido pela Intercom: Santos/SP, 29 de agosto a 2 de setembro de 2007.

DELBONI, C. Estudo revela o que pensam os jovens sobre a pandemia. Disponível em: https://emais.estadao.com.br/blogs/kids/estudo-revela-o-que-pensam-os-jovens-sobre-a-pandemia/ Set 2020. Acesso em nov. 2020.

DIAS, M.; BALAGO, R. Protestos por morte de homem negro se espalham pelos EUA e fecham Casa Branca. 29 mai. 2020. Disponível em: https://www1.folha.uol.com.br/mundo/2020/05/protestos-emwashington-por-morte-de-george-floyd-fecham-a-casa-branca.shtml Acesso em: 15 ago. 2020.

DIGITAL NEWS REPORT. Reuters Institute Digital News Report 2020. Disponível em: https://reutersinstitute.politics.ox.ac.uk/sites/default/files/2020-06/DNR_2020_FINAL.pdf Acesso em: 20 nov 2020.

E-INVESTIDOR. Expediente do Site. O Estado de S.Paulo, São Paulo, 21 de março de 2020. Disponível em: https://einvestidor.estadao.com.br/2020/03/21/equipe-e-investidor/. Acesso em: 15 de agosto de 2020.

EISNER, W. Quadrinhos e arte sequencial: princípios e práticas do lendário cartunista. 4. ed. São Paulo: WMF Martins Fontes, 2010. 
ERSTAD, O. e WERTSCH, J. V. Tales of mediation: Narrative and digital media as cultural tools. In Knut Lundby (ed) Digital Storytelling, Mediatized Stories. New York: Peter Lang, p. 21-40, 2008.

ESTADÃO (2020). 'Estadão Drops' alcança 3 milhões de visualizações. O Estado de S.Paulo, São Paulo, 12 de agosto de 2017. Disponível em: https://economia.estadao.com.br/noticias/geral,estadaodrops-alcanca-3-milhoes-de-visualizacoes,70001934017. Acesso em: 15 de agosto de 2020.

ESTADÃO (2020b). Expediente. Disponível em: https://einvestidor.estadao.com.br/2020/03/21/equipee-investidor/ Acesso em: 15 ago. 2020.

ETHERINGTON, D. Snapchat Gets Its Own Timeline With Snapchat Stories, 24-Hour Photo \& Video Tales. 3 Out. 2013. Disponível em: https://techcrunch.com/2013/10/03/snapchat-gets-its-own-timelinewith-snapchat-stories-24-hour-photo-video-tales/ Acesso em: 12 out. 2020.

FABRINI, Fábio. "Operação da Polícia Federal contra fake news mira oito deputados bolsonaristas". Folha de São Paulo, São Paulo, 27 de mai. de 2020. Poder. Disponível em: https://www1.folha.uol.com.br/poder/2020/05/operacao-da-policia-federal-contra-fake-news-mira-oitodeputados-bolsonaristas.shtml. Acesso em: 15 de agosto de 2020.

FLUSSER, V. Filosofia da caixa preta : ensaios para uma filosofia da fotografia. 1. ed. São Paulo: É Realizações, 2018.

FOLHA (2020). Após mau tempo, lançamento do SpaceX acontece neste sábado. https://www1.folha.uol.com.br/ciencia/2020/05/apos-mau-tempo-lancamento-do-spacex-aconteceneste-sabado.shtml Acesso em: 15 ago. 2020.

FOLHA (2020b). Folha suspende temporariamente cobertura no Alvorada por falta de segurança. Disponível em: https://www1.folha.uol.com.br/poder/2020/05/folha-suspende-temporariamentecobertura-no-alvorada-por-falta-de-seguranca.shtml Acesso em: 15 ago. 2020.

FOLHA (2020c). Folha lança Web Stories em parceria com o Google. 27 abr 2020. Disponível em: https://www1.folha.uol.com.br/webstories/2020/04/folha-lanca-web-stories-em-parceria-com-ogoogle.shtml Acesso em: 16 nov 2020.

FONTCUBERTA, J. La fúria de las imágenes: Notas sobre la postfotografía. Barcelona: Galaxia Gutemberg, 2016.

FORNASIER, M.; BECK, C. CAMBRIDGE ANALYTICA: ESCÂNDALO, LEGADO E POSSÍVEIS FUTUROS PARA A DEMOCRACIA. Revista Direito em Debate, v. 29, n. 53, p. 182-195, 26 maio 2020.

GABRIEL, M.; KISO, R. Marketing na era digital : conceitos, plataformas e estratégias. 2, ed. São Paulo: Atlas, 2020.

HAN, B. No enxame: perspectivas do digital. Petrópolis, RJ: Editora Vozes, 2018. 
HAN, B.C. Bom entretenimento: uma desconstrução da história da paixão ocidental. Petrópolis, RJ: Vozes, 2019.

HARARI, Y. 21 lições para o século 21. São Paulo: Companhia das Letras, 2018.

HARARI, Y. Yuval Harari: 'Temos conhecimento para derrotar a Covid-19. Se falharmos, é culpa dos políticos'. Nov. 2020. Disponível em: https://oglobo.globo.com/cultura/yuval-harari-temosconhecimento-para-derrotar-covid-19-se-falharmos-culpa-dos-politicos-24733189 Acesso em: 15 nov 2020.

HJARVARD, S. A midiatização da cultura e da sociedade. São Leopoldo, Ed. Unisinos, 2014.

INSTAGRAM (2016). Introducing Instagram Stories. Disponível em: https://instagrampress.com/br/blog/2016/08/02/introducing-instagram-stories/ . Acesso em: 1 ago. 2017.

INSTAGRAM (2019). Our Story. Disponível em: <https://instagram-press.com/our-story/>. Acesso em: 25 mai 2019.

ISAAC, M. Instagram Takes a Page From Snapchat, and Takes Aim at It, Too. The New York Times, 2 ago 2016. Disponível em: https://www.nytimes.com/2016/08/03/technology /instagram-storiessnapchat-facebook.html. Acesso em: 1 jul 2018.

JENKINS, Henry. Cultura da convergência. São Paulo: Aleph, 2009.

JENKINS, Henry; FORD, Sam; GREEN, Joshua. Cultura da Conexão: criando valor e significado por meio da mídia propagável. Tradução Patrícia Arnaud. São Paulo: Aleph, 2014.

KANNENBERG, V. Conteúdo jornalístico no Snapchat: apropriação do aplicativo pelo Portal UOL. Orientadora: Luciana Mielniczuk. 2018. 158 f. Dissertação (Mestrado em Comunicação e Informação) - Universidade Federal do Rio Grande do Sul, Porto Alegre, 2018.

KANNENBERG, Vanessa; SOUSA, Maíra Evangelista de. O fantasmagórico site de rede social: como - Snapchat está sendo apropriado para a circulação de conteúdo jornalístico. Intercom, Rev. Bras. Ciênc. Comun., São Paulo , v. 40, n. 3, p. 151-167, Dec. 2017 . Available from . access on 12 Nov. 2020. https://doi.org/10.1590/1809-5844201739.

KARHAWI, I.. Influenciadores digitais: o Eu como mercadoria. In. SAAD-CORREAA, E. N.. SILVEIRA, S. C. Tendências em Comunicação Digital. São Paulo: ECA-USP, 2016.

KIGHT, S. W. Gen $Z$ is eroding the power of misinformation. Set 2020. Disponível em: https://www.axios.com/gen-z-is-eroding-the-power-of-misinformation-5940e3cd-e3d0-44a1-b66c93be45fe1d2c.html Acesso em 10 nov. 2020. 
LACERDA, I. A cultura do efêmero: o formato Snapchat nas redes sociais, a vontade de exposição e a construção da imagem individual. In: XXII Congresso de Ciências da Comunicação na Região Sudeste - Intercom Sudeste, 2017, Volta Redonda, RJ. XXII Congresso de Ciências da Comunicação na Região Sudeste - Anais, 2017.

LAMBERT, N. M., Gwinn, A. M., Baumeister, R. F., Strachman, A., Washburn, I. J., Gable, S. L., \& Fincham, F. D. (2012). A boost of positive affect: The perks of sharing positive experiences. Journal of Social and Personal Relationships, 30(1), 24-43. doi:10.1177/0265407512449400

LAURENT, O. (2017). How Snapchat, Instagram and Apple Are Reinventing Photography Forever, 24 fev 2017. Disponível em: http://time.com/4659058/ napchat-instagram-apple-photography/ Acesso em: 1 jul 2018.

LEMOS, A., SAMPAIO, C. Mais livre para publicar: Efemeridade da Imagem nos modos Galeria e Stories do Instagram, Revista Mídia e Cotidiano, RJ, UFF, Volume 12, Número 2, agosto de 2018. Disponível em: http://periodicos.uff.br/midiaecotidiano/article/view/ 10035/8493 . Acesso em: 7 jan. 2019.

LIPOVETSKY, G.; SERROY, J. A estetização do mundo: viver na era do capitalismo artista. São Paulo: Companhia das Letras, 2015.

LUPTON, E. O design como storytelling. Osasco, SP: Gustavo Gili, 2020.

MACHADO, Arlindo. A arte do vídeo. 3. Ed. São Paulo: Brasiliense, 1995.

MACHADO, Arlindo. Pré-cinemas e pós cinemas. 2 ed. Campinas: Papiros, 2002.

MACHADO, Arlindo. Máquina e Imaginário: o Desafio das Poéticas Tecnológicas. $3^{a}$ edição. São Paulo: Editora da Universidade de São Paulo, 2001.

MADRIGAL, A. C.The Hashtag Is About to Roll Out to a Billion People, and This One Guy Invented It. 12 jun 2013. Disponível em: https://www.theatlantic.com/technology/archive/2013/06/the-hashtag-isabout-to-roll-out-to-a-billion-people-and-this-one-guy-invented-it/276811/ Acesso em 16 nov 2020.

MANIOU, A.T. AND VEGLIS, A., 2016. 'Selfie Journalism': Current Practices in Digital Media. Studies in Media and Communication, 4(1), pp.111-118.

MANIOU, T., PANAGIOTIDIS, K. AND VEGLIS, A., 2019, The Politicization of Selfie Journalism: An Empirical Study to Parliamentary Elections, chapter in Mehdi Khosrow-Pour (Ed) Journalism and Ethics: Breakthroughs in Research and Practice, IGI, pp 579-596.

MANOVICH, L. (2016). Instagram "stories" casual vs. Professional visual communication and study of visual culture. 2 ago 2016. Disponível em: https://www.facebook.com/notes/lev-manovich/instagram- 
stories-casual-vs-professional-visual-communication-and-study-of-visua/10153716718623456/.

Acesso em: 1 jul 2018.

MANOVICH, Lev. A interação como evento estético. Lumina: revista da Faculdade de Comunicação da UFJF, Juiz de Fora: UFJF, v.1, n.1. Disponível em: http://ojs2.ufj.emnuvens.com.br/lumina/article/view/20988. Acesso em: 15 jan 2019.

MARITZ, W. The most profound photo l've seen for a long time... Be. In. The. Moment. Maio 2018. Disponível em: https://www.facebook.com/willie.maritz/posts/10155495387377335 Acesso em 8 dez 2019.

MARQUES, J. Depois do Twitter, Facebook e Instagram também apagam post de Bolsonaro. 31 mar. 2020. Disponível em: https://www1.folha.uol.com.br/poder/2020/03/depois-do-twitter-facebooktambem-apaga-post-de-bolsonaro.shtml Acesso em: 20 set. 2020.

MARTINS, E.G.M. (2014) Diagrama de Venn. Rev. Ciência Elem., V2(01):020. doi.org/10.24927/rce2014.020

MAZUR, D.; DANNER, A. Quadrinhos: História Moderna de uma arte global. São Paulo: WMF Martins Fontes, 2014.

MEDIA OWNERSHIP MONITOR BRASIL (Estadão), 2017. Levantamento da MOM-Brasil que mostra as principais empresas do Grupo Estado. Disponível em: https://brazil.momrsf.org/br/proprietarios/empresas/detail/company/company/show/grupo-oesp-estado/ Acesso em: 10 jun. 2020.

MEDIA OWNERSHIP MONITOR BRASIL, (Folha) 2017. Levantamento da MOM-Brasil que mostra as principais empresas do Grupo Folha. Disponível em: https://brazil.momrsf.org/br/proprietarios/empresas/detail/company/company/show/grupo-folha/ Acesso em: 10 jun. 2020.

MEIO\&MENSAGEM (2019). Folha e Spotify lançam podcast diário com notícias. 2 jan. 2019. Disponível em: https://www.meioemensagem.com.br/home/ultimas-noticias/2019/01/02/folha-e-spotify-lancampodcast-diario-com-noticias.html Acesso em: 15 ago. 2020.

MELLO, P. C. Operação contra fake news reforça suspeitas das eleições de 2018. 1 jun 2020. Disponível em: https://www1.folha.uol.com.br/poder/2020/06/operacao-contra-fake-news-reforcasuspeitas-das-eleicoes-de-2018.shtml Acesso em 15 set. 2020.

MOROZOV, Evgeny. Big Tech. São Paulo: Ubu Editora, 2018.

MONTEIRO. Formato Stories conquista todas as redes sociais. 14 abr 2020. Disponível em: https://www.meioemensagem.com.br/home/midia/2020/04/14/formato-stories-conquista-as-maioresredes-sociais.html Acesso em: 15 set 2020. 
MUNGIOLI, M. C. Apontamentos para o estudo da narrativa. Comunicação \& Educação, n. 23, p. 4956, 30 abr. 2002.

MURRAY, J. Hamlet no Holodeck: o futuro da narrativa no ciberespaço. São Paulo: Itaú Cultural/Unesp, 2003.

PALACIOS, Marcos Silva; CUNHA, Rodrigo do Espírito Santo da. A tactilidade em dispositivos móveis: primeiras reflexões e ensaio de tipologias. Contemporânea, v. 10, p. 668-685, 2012.

PARISER, Eli. O filtro invisível: o que a internet está escondendo de você. Rio de Janeiro: Zahar, 2012 PIWEK, Lukasz; JOINSON, Adam. "What do they snapchat about?" Patterns of use in time-limited instant messaging service. Computers in Human Behavior. v. 54. p. 358 - 367. Jan 2016. Disponível em: https://doi.org/10.1016/j.chb.2015.08.026. Acesso em: 23 mar 2019.

POST-TRUTH. Oxford Dictionaries Word of the Year 2016. Disponível em: https://languages.oup.com/word-of-the-year/2016/～Acesso em: 11 de out. 2020

QUEIROZ, S. Emojis, gifs e engajamento. Quando e por que utilizá-los? 2 mai 2019. Disponível em: http://automacaodevendas.com/emojis-e-gifs-quando-utiliza-los/ Acesso em: 10 set 2020.

RASHIDIAN et al. Platforms and Publishers: The End of an Era. Nov 2019. Disponível em: https://www.cjr.org/tow_center_reports/platforms-and-publishers-end-of-an-era.php Acesso em: 20 nov 2020.

RAMOS, D. O. A expansão do jornalismo para o ambiente numérico. 1. ed. Curitiba: Appris, 2016.

REDDIT. The Difference Between Generations. Set. 2015. Disponível em: https://www.reddit.com/r/pics/comments/3lpwj6/the_difference_between_generations/ Acesso em 8 dez 2019.

RIBEIRO, Bruno; VENCESLAU, Pedro; et al. "Doria permite reabertura de shoppings e lojas na cidade de SP a partir de junho". O Estado de S.Paulo, São Paulo, 27 de maio de 2020. Disponível em: https://saude.estadao.com.br/noticias/geral,doria-anuncia-retomada-consciente-a-partir-de-1-dejunho-quarentena-e-prorrogada-ate-dia-15,70003316259. Acesso em: 15 de agosto de 2020.

RIBEIRO, Bruno; VENCESLAU, Pedro; et al. "Doria permite reabertura de shoppings e lojas na cidade de SP a partir de junho". O Estado de S.Paulo, São Paulo, 27 de maio de 2020. Disponível em: $<$ https://saude.estadao.com.br/noticias/geral,doria-anuncia-retomada-consciente-a-partir-de-1-dejunho-quarentena-e-prorrogada-ate-dia-15,70003316259>. Acesso em: 15 de agosto de 2020.

RYAN, Kathleen M. Vertical video: rupturing the aesthetic paradigm. Visual Communication. Maio 2018 v. 17, n. 2, p. 245-261. Disponível em: https://journals.sagepub.com/doi/10.1177/1470357217736660. Acesso em: 15 abr 2019. 
RUKEYZER, Muriel. The Speed of Darkness. Nova York: Random House, 1968.

SAAD CORREAA, Elizabeth; BERTOCCHI, Daniela. O algoritmo curador: o papel do comunicador num cenário de curadoria algorítmica de informação. 2012. Disponível em: https://bibliodigital.unijui.edu.br:8443/xmlui/handle/123456789/2852 Acesso em 10 nov 2020.

SAAD CORRÊA, Elizabeth; CARLAN DA SILVEIRA, Stefanie. Proposta teórico-metodológica para a pesquisa de objetos no jornalismo. Matrizes. V.11 - № 2 maio/ago. 2017, p. 163-182.

SANTAELLA, L. A Pós-Verdade é verdadeira ou falsa?. Barueri, SP: Estação das Letras e cores, 2019. SANTAELLA, L. Cultura das Mídias. São Paulo: Experimento, 1996.

SANTAELLA, L. Os jovens como termômetros do Zeitgeist. In: ROCHA, C; SANTAELLA, L. (Org.). A onipresença dos jovens nas redes. 1ed. Goiânia: Editora da Universidade Federal de Goiás, 2015, v. 1 , p. 31-46.

SERPA, F. Redes Sociais: O Uso Do Instagram Stories Pelo Drops Estadão. https://www.univates.br/bdu/bitstream/10737/2712/1/2019FrancielendeGoisSerpa.pdf Acesso em 07 out. 2020.

SIBILIA, P. O show do Eu: a intimidade como espetáculo. Rio de Janeiro: Contraponto, 2016.

SILVEIRA, S. C. da. Além do jornalismo móvel: o jornalismo ubíquo e o contexto de consumo de informação. Trabalho apresentado no V CONGRESSO INTERNACIONAL DE CIBERJORNALISMO. Universidade do Porto, Portugal, 2016. Disponível em: https://cobciber5.files.wordpress.com/2017/05/atas_5cobciber.pdf

SNAP (2013). Surprise. Disponível em: https://www.snap.com/en-US/news/post/surprise/. Acesso em 7 mai 2018.

SNAP (2015). Introducing Discover. Disponível em: https://www.snap.com/enUS/news/post/introducing-discover/. Acesso em 7 mai 2018.

SOUZA E SILVA, W. (2015b). Fotografia e interfaces digitais: convergência entre produção, comunicação e significação. REVISTA GEMInIS, v. 6, p. 329-340, 2015.

SOUZA E SILVA, W.; VELLEI, C. S. . O Corpo Protagonista nas Telas Verticais: a Influência do Enquadramento Retrato dos Smartphones no Universo Imagético. COMUNICAÇÃO \& INOVAÇÃO (ONLINE), v. 21, p. 28-45, 2020.

TERRA, A. \#NãoÉSóUmaHashtag. 14 jan. 2019. Disponível em: https://tab.uol.com.br/edicao/hashtag/ Acesso em: 10 nov. 2020. 
TIC KIDS ONLINE BRASIL. TIC KIDS ONLINE BRASIL 2019: Principais resultados. 2020. Disponível em: https://cetic.br/pt/pesquisa/kids-online/analises/ Acesso em: 10 nov. 2020.

VAN DIJCK, J. Digital photography: communication, identity, memory. In: Visual Communication, 7(1). 2008. p. 57-76. Disponível em: http://hdl.handle.net/11245/2.67164. Acesso em: 2 de janeiro de 2019.

VAN DIJCK, J. The Culture of Connectivity: A Critical History of Social Media. Nova York: Oxford University Press, 2013.

VAN DIJCK, J.; POELL, T.; DE WAAL, M.C. Revista Fronteiras - estudos midiáticos. 22(1):2-10 janeiro/abril 2020. Unisinos - doi: 10.4013/fem.2020.221.01

VAN DIJCK, J.; POELL, T.; DE WAAL, M.C. The Platform Society: Public Values in a Connected World. Nova York: Oxford University Press, 2018.

VANNUCHI, C. A pandemia de Covid-19 segundo Bolsonaro: da "gripezinha" ao "e daí?". 30 abr. 2020. Disponível em: https://noticias.uol.com.br/colunas/camilo-vannuchi/2020/04/30/a-pandemia-de-covid19-segundo-bolsonaro-da-gripezinha-ao-e-dai.htm Acesso em: 20 set. 2020.

VASCONCELOS, E. L. Do impresso ao Snapchat: a efemeridade enquanto característica essencial do jornalismo. Revista Comunicação, Cultura e Sociedade , v. 7, p. 89-102, 2017. Disponível em: https://periodicos.unemat.br/index.php/ccs/article/view/2204. Acesso em: 15 jun 2018.

VELLEI, C. A Hora E A Vez Do Instantâneo: Estratégias De Gerenciamento Da Memória Nas Mídias Sociais Efêmeras. III Simpósio Internacional de Comunicação e Cultura: aproximações com a memória e com a história oral. São Caetano do Sul, 2019.

VITORIO, T. Não é só selfie: Instagram vira fonte de informação. Out. 2020. Disponível em: https://exame.com/tecnologia/nao-e-so-selfie-instagram-vira-fonte-de-informacao/ Acesso em: Nov. 2020.

WE ARE SOCIAL, Global digital overview 2020 - Hootsuite. Disponível em: https://wearesocial.com/digital-2020 Acesso em 14 nov 2020.

WOLF, Mauro. Teorias da Comunicação. Lisboa: Editora Presença, 2006.

XU, B.; CHANG, P.; WELKER, C.L.; BAZAROVA, N. N.; COSLEY, D. Automatic archiving versus default deletion: what Snapchat tells us about ephemerality in design. In: Proceedings of the 19th ACM Conference on Computer-Supported Cooperative Work \& Social Computing. San Francisco: ACM, p. 1662-1675, 2016. Disponível em: https://dl.acm.org/citation.cfm?id=2819948. Acesso em: 10 jan. 2018.

ZDAN, A. (@ActualAlexZ). “So THAT's what it's like to go viral...” 7 nov 2020. Tweet. 


\section{APÊNDICE A - LISTA DE PERFIS SEGUIDOS PELA CONTA @MESTRADODACAROL}

\author{
@abcnews \\ @afpphoto \\ @agazetaes \\ @ajplus \\ @aljazeeraenglish \\ @anistiabrasil \\ @apnews \\ @aventurasnahistoria \\ @bandsports \\ @bandtv \\ $@ b b c$ \\ @bbc_culture \\ @bbc_travel \\ @bbcafrica \\ @bbcamerica \\ @bbcbrasil \\ @bbcbritain \\ @bbcearth \\ @bbcfood \\ @bbciplayer \\ @bbclearningenglish \\ @bbcnews \\ @bbcnewsbeat \\ @bbcradio1 \\ @bbcradio2 \\ @bbcsounds \\ @bbcsport \\ @bbctheoneshow \\ @bbcthree \\ @bbctwo \\ @besidone \\ @brasildefato \\ @buzzfeed \\ @buzzfeednews \\ @canalbrasil \\ @canalhistory \\ @carasbrasil \\ @cartacapital \\ @catracalivre \\ @cbcnews \\ @cbctoronto \\ @cbsnews \\ @cbssports \\ @cnbc \\ @cnn \\ @cnnpolitics \\ @cultrevista \\ @dailymail \\ @dailymirror \\ @desimpedidos \\ @diariodopoder \\ @discovery
}

@discoverybr

@dqker.nation

@elpaisbrasil

@enews

@epocanegocios

@espn

@espnbrasil

@espndeportes

@esporteinterativo

@estadao

@estadaocultura

@estadaoesporte

@exame

@financialtimes

@folhadespaulo

@forbes

@forbesbr

@foxsports

@foxsportsbrasil

@ge.globo

@gettyentertainment

@gettyimages

@gettyreportage

@globointernacional

@globonews

@globoreporter

@gnt

@gshow

@guardian

@guiafolha

@gzhdigital

@history

@infomoney

@instagram

@itvnews

@jornalextra

@jornalhoje

@jornalistaslivres

@jornaloglobo

@life

$@$ midianinja

@mundoestranho

@natgeo

@natgeoadventure

@natgeobrasil

@natgeochannel

@natgeointhefield

@natgeotravel

@natgeowild

@nbcnews

@nbcsports

@nexojornal @nowthisearth

@nowthisentertainment

@nowthisher

@nowthisnews

@nytimes

@ok_mag

@omelete

@portalg1

@portalr7

@recordtvoficial

@redeglobo

@redetv

@reuters

@reuterssport

@revistaepoca

@revistaforum

@revistagalileu

@revistaistoe

@revistapegn

@revistasuper

@sbtonline

@showdavida

@skynews

@sportscenter

@sportv

@telegraph

@terrabrasil

@thedailyshow

@thedailyvox

@theeconomist

@thesun

@thetimes

@time

@timelightbox

@universa_uol

@uolesporte

@uoloficial

@usatodaysports

@usweekly

@vejanoinsta

@vejasp

@viagemeturismo

@vice

@vicetv

@voguemagazine

@voxdotcom

@warphotoagency

@washingtonpost

@whatsupnorthtv

@worldpressphoto

@wsj 


\section{APÊNDICE B - PANORAMA NUMÉRICO DA ANÁLISE DO ESTADÃO}

\begin{tabular}{|c|c|c|c|c|c|c|c|c|}
\hline Indicadores Estadão & Segunda & $17 \%$ & Terça & $15 \%$ & Quarta & $26 \%$ & Quinta & $13 \%$ \\
\hline Total de stories & 21 & $100 \%$ & 19 & $100 \%$ & 33 & $100 \%$ & 17 & $100 \%$ \\
\hline \multicolumn{9}{|l|}{ Temporalidade } \\
\hline \multicolumn{9}{|l|}{ E-39 Período do dia } \\
\hline Manhã & 0 & $0 \%$ & 0 & $0 \%$ & 0 & $0 \%$ & 0 & $0 \%$ \\
\hline Tarde & 12 & $57 \%$ & 7 & $37 \%$ & 28 & $85 \%$ & 6 & $35 \%$ \\
\hline Noite & 9 & $43 \%$ & 12 & $63 \%$ & 5 & $15 \%$ & 11 & $65 \%$ \\
\hline E-40 Urgente & 0 & $0 \%$ & 0 & $0 \%$ & 0 & $0 \%$ & 0 & $0 \%$ \\
\hline \multicolumn{9}{|l|}{ Temática } \\
\hline E-09 Presença humana & 17 & $81 \%$ & 13 & $68 \%$ & 23 & $70 \%$ & 12 & $71 \%$ \\
\hline E-20 Adesivo & 8 & $38 \%$ & 11 & $58 \%$ & 4 & $12 \%$ & 4 & $24 \%$ \\
\hline \multicolumn{9}{|l|}{ E-13 Assunto central } \\
\hline Política & 4 & $20 \%$ & 7 & $39 \%$ & 6 & $21 \%$ & 4 & $25 \%$ \\
\hline Coronavírus & 9 & $45 \%$ & 6 & $33 \%$ & 10 & $36 \%$ & 7 & $44 \%$ \\
\hline Internacional & 0 & $0 \%$ & 0 & $0 \%$ & 3 & $11 \%$ & 1 & $6 \%$ \\
\hline Economia & 1 & $5 \%$ & 2 & $11 \%$ & 2 & $7 \%$ & 2 & $13 \%$ \\
\hline Saúde & 1 & $5 \%$ & 0 & $0 \%$ & 0 & $0 \%$ & 0 & $0 \%$ \\
\hline Ciência & 0 & $0 \%$ & 0 & $0 \%$ & 1 & $4 \%$ & 0 & $0 \%$ \\
\hline Capa & 0 & $0 \%$ & 0 & $0 \%$ & 0 & $0 \%$ & 0 & $0 \%$ \\
\hline Expediente & 0 & $0 \%$ & 0 & $0 \%$ & 0 & $0 \%$ & 0 & $0 \%$ \\
\hline Webstories & 0 & $0 \%$ & 0 & $0 \%$ & 0 & $0 \%$ & 0 & $0 \%$ \\
\hline Cultura & 3 & $15 \%$ & 2 & $11 \%$ & 5 & $18 \%$ & 2 & $13 \%$ \\
\hline \multirow[t]{2}{*}{ Esporte } & 2 & $10 \%$ & 1 & $6 \%$ & 1 & $4 \%$ & 0 & $0 \%$ \\
\hline & 20 & $100 \%$ & 18 & $100 \%$ & 28 & $100 \%$ & 16 & $100 \%$ \\
\hline \multicolumn{9}{|l|}{ Referência } \\
\hline E-02 Layout personalizado & 0 & $0 \%$ & 2 & $11 \%$ & 1 & $3 \%$ & 1 & $6 \%$ \\
\hline E-03 Layout nativo & 21 & $100 \%$ & 17 & $89 \%$ & 32 & $97 \%$ & 16 & $94 \%$ \\
\hline E-17 Imagem jornalística & 9 & $43 \%$ & 5 & $26 \%$ & 17 & $52 \%$ & 10 & $59 \%$ \\
\hline E-18 Imagem reproduzida & 11 & $52 \%$ & 8 & $42 \%$ & 14 & $42 \%$ & 6 & $35 \%$ \\
\hline E-19 Não é possível saber & 1 & $5 \%$ & 6 & $32 \%$ & 2 & $6 \%$ & 3 & $18 \%$ \\
\hline E-15 Créditos dos stories & 0 & $0 \%$ & 1 & $5 \%$ & 0 & $0 \%$ & 0 & $0 \%$ \\
\hline E-14 Créditos das imagens & 2 & $10 \%$ & 1 & $5 \%$ & 0 & $0 \%$ & 0 & $0 \%$ \\
\hline E-26 Texto semelhante & 14 & $67 \%$ & 15 & $79 \%$ & 18 & $55 \%$ & 14 & $82 \%$ \\
\hline Texto semelhante $(B C+E d)$ & ó bc+ed & $70 \%$ & bcted & $83 \%$ & ó bcted & $64 \%$ & só bc+ed & $88 \%$ \\
\hline \multicolumn{9}{|l|}{ Formato } \\
\hline E-04 vertical/full screen & 19 & $90 \%$ & 18 & $95 \%$ & 28 & $85 \%$ & 15 & $88 \%$ \\
\hline E-05 quadrada/horizontal & 2 & $10 \%$ & 1 & $5 \%$ & 5 & $15 \%$ & 2 & $12 \%$ \\
\hline \multicolumn{9}{|l|}{ E-06 Filtro } \\
\hline Com filtro & 6 & $29 \%$ & 8 & $42 \%$ & 8 & $24 \%$ & 5 & $29 \%$ \\
\hline Sem filtro & 15 & $71 \%$ & 11 & $58 \%$ & 25 & $76 \%$ & 12 & $71 \%$ \\
\hline E-07 Imagem estática & 6 & $29 \%$ & 7 & $37 \%$ & 22 & $67 \%$ & 7 & $41 \%$ \\
\hline E-08 Com movimento & 15 & $71 \%$ & 12 & $63 \%$ & 11 & $33 \%$ & 10 & $59 \%$ \\
\hline E-16 Jornalista selfie & 2 & $10 \%$ & 2 & $11 \%$ & 6 & $18 \%$ & 4 & $24 \%$ \\
\hline E-24 Texto & 21 & $100 \%$ & 19 & $100 \%$ & 33 & $100 \%$ & 17 & $100 \%$ \\
\hline
\end{tabular}




\begin{tabular}{|c|c|c|c|c|c|c|c|c|}
\hline E-28 Áudio & 10 & $48 \%$ & 8 & $42 \%$ & 8 & $24 \%$ & 8 & $47 \%$ \\
\hline E-25 Palavras por story & 21,5 & média & 26,1 & média & 19,6 & média & 20,8 & média \\
\hline Finalidade & & & & & & & & \\
\hline E-10 Publicidade & 1 & $5 \%$ & 1 & $5 \%$ & 5 & $15 \%$ & 1 & $6 \%$ \\
\hline E-11 Branded content & 1 & $5 \%$ & 2 & $11 \%$ & 2 & $6 \%$ & 2 & $12 \%$ \\
\hline E-12 Editorial - Jornalismo & 19 & $90 \%$ & 16 & $84 \%$ & 26 & $79 \%$ & 14 & $82 \%$ \\
\hline BC + Editorial & 20 & & 18 & & 28 & & 16 & \\
\hline Interatividade & & & & & & & & \\
\hline E-21 Localização & 2 & $10 \%$ & 1 & $5 \%$ & 0 & $0 \%$ & 0 & $0 \%$ \\
\hline E-22 Hashtag \# & 0 & $0 \%$ & 0 & $0 \%$ & 2 & $6 \%$ & 0 & $0 \%$ \\
\hline E-23 Tag de Música & 0 & $0 \%$ & 0 & $0 \%$ & 0 & $0 \%$ & 0 & $0 \%$ \\
\hline E-36 Interação (enquete) & 1 & $5 \%$ & 3 & $16 \%$ & 0 & $0 \%$ & 0 & $0 \%$ \\
\hline E-38 Mensagens diretas & 0 & $0 \%$ & 1 & $5 \%$ & 1 & $3 \%$ & 0 & $0 \%$ \\
\hline Hiperlink & & & & & & & & \\
\hline E-29 Com link & 21 & $100 \%$ & 18 & $95 \%$ & 32 & $97 \%$ & 17 & $100 \%$ \\
\hline E-30 Com paywall & 18 & $86 \%$ & 14 & $74 \%$ & 19 & $58 \%$ & 14 & $82 \%$ \\
\hline E-31 Sem paywall & 2 & $10 \%$ & 3 & $16 \%$ & 4 & $12 \%$ & 3 & $18 \%$ \\
\hline E-32 Aplicativo & 1 & $5 \%$ & 1 & $5 \%$ & 5 & $15 \%$ & 0 & $0 \%$ \\
\hline E-33 Publicidade & 1 & $5 \%$ & 1 & $5 \%$ & 5 & $15 \%$ & 1 & $6 \%$ \\
\hline E-34 branded content & 1 & $5 \%$ & 2 & $11 \%$ & 2 & $6 \%$ & 2 & $12 \%$ \\
\hline E-35 Repost & 1 & $5 \%$ & 1 & $5 \%$ & 2 & $6 \%$ & 1 & $6 \%$ \\
\hline E-37 Menção @ & 4 & $19 \%$ & 5 & $26 \%$ & 9 & $27 \%$ & 5 & $29 \%$ \\
\hline
\end{tabular}




\begin{tabular}{|c|c|c|c|c|c|c|}
\hline Indicadores Estadão & Sexta & $23 \%$ & Sábado & $2 \%$ & Domingo & $4 \%$ \\
\hline Total de stories & 29 & $100 \%$ & 2 & $100 \%$ & 5 & $100 \%$ \\
\hline \multicolumn{7}{|l|}{ Temporalidade } \\
\hline \multicolumn{7}{|l|}{ E-39 Período do dia } \\
\hline Manhã & 0 & $0 \%$ & 2 & $100 \%$ & 0 & $0 \%$ \\
\hline Tarde & 14 & $48 \%$ & 0 & $0 \%$ & 5 & $100 \%$ \\
\hline Noite & 15 & $52 \%$ & 0 & $0 \%$ & 0 & $0 \%$ \\
\hline E-40 Urgente & 0 & $0 \%$ & 0 & $0 \%$ & 0 & $0 \%$ \\
\hline \multicolumn{7}{|l|}{ Temática } \\
\hline E-09 Presença humana & 17 & $59 \%$ & 0 & $0 \%$ & 3 & $60 \%$ \\
\hline E-20 Adesivo & 22 & $76 \%$ & 0 & $0 \%$ & 2 & $40 \%$ \\
\hline \multicolumn{7}{|l|}{ E-13 Assunto central } \\
\hline Política & 3 & $11 \%$ & 0 & $0 \%$ & 0 & $0 \%$ \\
\hline Coronavírus & 7 & $26 \%$ & 0 & $0 \%$ & 0 & $0 \%$ \\
\hline Internacional & 4 & $15 \%$ & 0 & $0 \%$ & 0 & $0 \%$ \\
\hline Economia & 2 & $7 \%$ & 0 & $0 \%$ & 0 & $0 \%$ \\
\hline Saúde & 0 & $0 \%$ & 0 & $0 \%$ & 0 & $0 \%$ \\
\hline Ciência & 1 & $4 \%$ & 0 & $0 \%$ & 0 & $0 \%$ \\
\hline Capa & 0 & $0 \%$ & 0 & $0 \%$ & 0 & $0 \%$ \\
\hline Expediente & 1 & $4 \%$ & 0 & $0 \%$ & 0 & $0 \%$ \\
\hline Webstories & 0 & $0 \%$ & 0 & $0 \%$ & 0 & $0 \%$ \\
\hline Cultura & 8 & $30 \%$ & 0 & $0 \%$ & 0 & $0 \%$ \\
\hline \multirow[t]{2}{*}{ Esporte } & 1 & $4 \%$ & 0 & $0 \%$ & 0 & $0 \%$ \\
\hline & 27 & $100 \%$ & 0 & $100 \%$ & 0 & $100 \%$ \\
\hline \multicolumn{7}{|l|}{ Referência } \\
\hline E-02 Layout personalizado & 0 & $0 \%$ & 1 & $50 \%$ & 0 & $0 \%$ \\
\hline E-03 Layout nativo & 29 & $100 \%$ & 1 & $50 \%$ & 5 & $100 \%$ \\
\hline E-17 Imagem jornalística & 11 & $38 \%$ & 0 & $0 \%$ & 0 & $0 \%$ \\
\hline E-18 Imagem reproduzida & 21 & $72 \%$ & 2 & $100 \%$ & 5 & $100 \%$ \\
\hline E-19 Não é possível saber & 2 & $7 \%$ & 0 & $0 \%$ & 0 & $0 \%$ \\
\hline E-15 Créditos dos stories & 1 & $3 \%$ & 0 & $0 \%$ & 0 & $0 \%$ \\
\hline E-14 Créditos das imagens & 0 & $0 \%$ & 0 & $0 \%$ & 0 & $0 \%$ \\
\hline E-26 Texto semelhante & 21 & $72 \%$ & 0 & $0 \%$ & 0 & $0 \%$ \\
\hline Texto semelhante $(B C+E d)$ & só bc+ed & $78 \%$ & só bc+ed & $0 \%$ & só bc+ed & $0 \%$ \\
\hline \multicolumn{7}{|l|}{ Formato } \\
\hline E-04 vertical/full screen & 24 & $83 \%$ & 1 & $50 \%$ & 0 & $0 \%$ \\
\hline E-05 quadrada/horizontal & 5 & $17 \%$ & 1 & $50 \%$ & 5 & $100 \%$ \\
\hline \multicolumn{7}{|l|}{ E-06 Filtro } \\
\hline Com filtro & 6 & $21 \%$ & 0 & $0 \%$ & 0 & $0 \%$ \\
\hline Sem filtro & 23 & $79 \%$ & 2 & $100 \%$ & 5 & $100 \%$ \\
\hline E-07 Imagem estática & 5 & $17 \%$ & 1 & $50 \%$ & 1 & $20 \%$ \\
\hline E-08 Com movimento & 24 & $83 \%$ & 1 & $50 \%$ & 4 & $80 \%$ \\
\hline E-16 Jornalista selfie & 3 & $10 \%$ & 0 & $0 \%$ & 0 & $0 \%$ \\
\hline E-24 Texto & 29 & $100 \%$ & 2 & $100 \%$ & 5 & $100 \%$ \\
\hline
\end{tabular}




\begin{tabular}{|c|c|c|c|c|c|c|}
\hline E-28 Áudio & 18 & $62 \%$ & 1 & $50 \%$ & 2 & $40 \%$ \\
\hline E-25 Palavras por story & 22,7 & média & 18 & média & 21 & média \\
\hline \multicolumn{7}{|l|}{ Finalidade } \\
\hline E-10 Publicidade & 2 & $7 \%$ & 2 & $100 \%$ & 5 & $100 \%$ \\
\hline E-11 Branded content & 2 & $7 \%$ & 0 & $0 \%$ & 0 & $0 \%$ \\
\hline E-12 Editorial - Jornalismo & 25 & $86 \%$ & 0 & $0 \%$ & 0 & $0 \%$ \\
\hline BC + Editorial & 27 & & 0 & & 0 & \\
\hline \multicolumn{7}{|l|}{ Interatividade } \\
\hline E-21 Localização & 2 & $7 \%$ & 0 & $0 \%$ & 0 & $0 \%$ \\
\hline E-22 Hashtag \# & 1 & $3 \%$ & 0 & $0 \%$ & 0 & $0 \%$ \\
\hline E-23 Tag de Música & 2 & $7 \%$ & 0 & $0 \%$ & 0 & $0 \%$ \\
\hline E-36 Interação (enquete) & 0 & $0 \%$ & 0 & $0 \%$ & 0 & $0 \%$ \\
\hline E-38 Mensagens diretas & 2 & $7 \%$ & 0 & $0 \%$ & 0 & $0 \%$ \\
\hline \multicolumn{7}{|l|}{ Hiperlink } \\
\hline E-29 Com link & 27 & $93 \%$ & 2 & $100 \%$ & 5 & $100 \%$ \\
\hline E-30 Com paywall & 17 & $59 \%$ & 0 & $0 \%$ & 0 & $0 \%$ \\
\hline E-31 Sem paywall & 6 & $21 \%$ & 1 & $50 \%$ & 3 & $60 \%$ \\
\hline E-32 Aplicativo & 2 & $7 \%$ & 1 & $50 \%$ & 2 & $40 \%$ \\
\hline E-33 Publicidade & 2 & $7 \%$ & 2 & $100 \%$ & 5 & $100 \%$ \\
\hline E-34 branded content & 2 & $7 \%$ & 0 & $0 \%$ & 0 & $0 \%$ \\
\hline E-35 Repost & 3 & $10 \%$ & 1 & $50 \%$ & 3 & $60 \%$ \\
\hline E-37 Menção @ & 9 & $31 \%$ & 0 & $0 \%$ & 4 & $80 \%$ \\
\hline
\end{tabular}




\begin{tabular}{|c|c|c|c|c|c|c|}
\hline Indicadores Estadão & SEMANAL & $\%$ total & SEG-SEX & $\%$ total & $\begin{array}{l}\text { FIM DE } \\
\text { SEMANA }\end{array}$ & $\%$ total \\
\hline Total de stories & 126 & $100 \%$ & 119 & $100 \%$ & 7 & $100 \%$ \\
\hline \multicolumn{7}{|l|}{ Temporalidade } \\
\hline \multicolumn{7}{|l|}{ E-39 Período do dia } \\
\hline Manhã & 2 & $1,59 \%$ & 0 & $0 \%$ & 2 & $29 \%$ \\
\hline Tarde & 72 & $57,14 \%$ & 67 & $56 \%$ & 5 & $71 \%$ \\
\hline Noite & 52 & $41,27 \%$ & 52 & $44 \%$ & 0 & $0 \%$ \\
\hline E-40 Urgente & $0 \%$ & $0 \%$ & 0 & $0 \%$ & 0 & $0 \%$ \\
\hline \multicolumn{7}{|l|}{ Temática } \\
\hline E-09 Presença humana & 85 & $67 \%$ & 82 & $69 \%$ & 3 & $43 \%$ \\
\hline E-20 Adesivo & 51 & $40 \%$ & 49 & $41 \%$ & 2 & $29 \%$ \\
\hline \multicolumn{7}{|l|}{ E-13 Assunto central } \\
\hline Política & 24 & $22 \%$ & 24 & $22 \%$ & 0 & $0 \%$ \\
\hline Coronavírus & 39 & $36 \%$ & 39 & $36 \%$ & 0 & $0 \%$ \\
\hline Internacional & 8 & $7 \%$ & 8 & $7 \%$ & 0 & $0 \%$ \\
\hline Economia & 9 & $8 \%$ & 9 & $8 \%$ & 0 & $0 \%$ \\
\hline Saúde & 1 & $1 \%$ & 1 & $1 \%$ & 0 & $0 \%$ \\
\hline Ciência & 2 & $2 \%$ & 2 & $2 \%$ & 0 & $0 \%$ \\
\hline Capa & 0 & $0 \%$ & 0 & $0 \%$ & 0 & $0 \%$ \\
\hline Expediente & 1 & $1 \%$ & 1 & $1 \%$ & 0 & $0 \%$ \\
\hline Webstories & 0 & $0 \%$ & 0 & $0 \%$ & 0 & $0 \%$ \\
\hline Cultura & 20 & $18 \%$ & 20 & $18 \%$ & 0 & $0 \%$ \\
\hline \multirow[t]{2}{*}{ Esporte } & 5 & $5 \%$ & 5 & $5 \%$ & 0 & $0 \%$ \\
\hline & 109 & $100 \%$ & 109 & $100 \%$ & 0 & $0 \%$ \\
\hline \multicolumn{7}{|l|}{ Referência } \\
\hline E-02 Layout personalizado & 5 & $4 \%$ & 4 & $3 \%$ & 1 & $14 \%$ \\
\hline E-03 Layout nativo & 121 & $96 \%$ & 115 & $97 \%$ & 6 & $86 \%$ \\
\hline E-17 Imagem jornalística & 52 & $41 \%$ & 52 & $44 \%$ & 0 & $0 \%$ \\
\hline E-18 Imagem reproduzida & 67 & $53 \%$ & 60 & $50 \%$ & 7 & $100 \%$ \\
\hline E-19 Não é possível saber & 14 & $11 \%$ & 14 & $12 \%$ & 0 & $0 \%$ \\
\hline E-15 Créditos dos stories & 2 & $2 \%$ & 2 & $2 \%$ & 0 & $0 \%$ \\
\hline E-14 Créditos das imagens & 3 & $2 \%$ & 3 & $3 \%$ & 0 & $0 \%$ \\
\hline E-26 Texto semelhante & 82 & $65 \%$ & 82 & $69 \%$ & 0 & $0 \%$ \\
\hline Texto semelhante $(B C+E d)$ & só bc+ed & $75 \%$ & só bcted & $75 \%$ & só bc+ed & $0 \%$ \\
\hline \multicolumn{7}{|l|}{ Formato } \\
\hline E-04 vertical/full screen & 105 & $83 \%$ & 104 & $87 \%$ & 1 & $14 \%$ \\
\hline E-05 quadrada/horizontal & 21 & $17 \%$ & 15 & $13 \%$ & 6 & $86 \%$ \\
\hline \multicolumn{7}{|l|}{ E-06 Filtro } \\
\hline Com filtro & 33 & $26 \%$ & 33 & $28 \%$ & 0 & $0 \%$ \\
\hline Sem filtro & 93 & $74 \%$ & 86 & $72 \%$ & 7 & $100 \%$ \\
\hline E-07 Imagem estática & 49 & $39 \%$ & 47 & $39 \%$ & 2 & $29 \%$ \\
\hline E-08 Com movimento & 77 & $61 \%$ & 72 & $61 \%$ & 5 & $71 \%$ \\
\hline E-16 Jornalista selfie & 17 & $13 \%$ & 17 & $14 \%$ & 0 & $0 \%$ \\
\hline E-24 Texto & 126 & $100 \%$ & 119 & $100 \%$ & 7 & $100 \%$ \\
\hline
\end{tabular}




\begin{tabular}{|c|c|c|c|c|c|c|}
\hline \multirow{2}{*}{$\begin{array}{l}\text { E-28 Áudio } \\
\text { E-25 Palavras por story }\end{array}$} & 55 & $44 \%$ & 52 & $44 \%$ & 3 & $43 \%$ \\
\hline & 21,3 & média & \multicolumn{2}{|c|}{ 21,4 média } & \multicolumn{2}{|c|}{20 média } \\
\hline \multicolumn{7}{|l|}{ Finalidade } \\
\hline E-10 Publicidade & 17 & $13,49 \%$ & 10 & $8 \%$ & 7 & $100 \%$ \\
\hline E-11 Branded content & 9 & $7,14 \%$ & 9 & $8 \%$ & 0 & $0 \%$ \\
\hline E-12 Editorial - Jornalismo & 100 & $79,37 \%$ & 100 & $84 \%$ & 0 & $0 \%$ \\
\hline BC + Editorial & 109 & & 109 & & 0 & \\
\hline \multicolumn{7}{|l|}{ Interatividade } \\
\hline E-21 Localização & 5 & $4 \%$ & 5 & $4 \%$ & 0 & $0 \%$ \\
\hline E-22 Hashtag \# & 3 & $2 \%$ & 3 & $3 \%$ & 0 & $0 \%$ \\
\hline E-23 Tag de Música & 2 & $2 \%$ & 2 & $2 \%$ & 0 & $0 \%$ \\
\hline E-36 Interação (enquete) & 4 & $3 \%$ & 4 & $3 \%$ & 0 & $0 \%$ \\
\hline E-38 Mensagens diretas & 4 & $3 \%$ & 4 & $3 \%$ & 0 & $0 \%$ \\
\hline \multicolumn{7}{|l|}{ Hiperlink } \\
\hline E-29 Com link & 122 & $96,83 \%$ & 115 & $97 \%$ & 7 & $100 \%$ \\
\hline E-30 Com paywall & 82 & $65,08 \%$ & 82 & $69 \%$ & 0 & $0 \%$ \\
\hline E-31 Sem paywall & 22 & $17,46 \%$ & 18 & $15 \%$ & 4 & $57 \%$ \\
\hline E-32 Aplicativo & 12 & $9,52 \%$ & 9 & $8 \%$ & 3 & $43 \%$ \\
\hline E-33 Publicidade & 17 & $13,49 \%$ & 10 & $8 \%$ & 7 & $100 \%$ \\
\hline E-34 branded content & 9 & $7,14 \%$ & 9 & $8 \%$ & 0 & $0 \%$ \\
\hline E-35 Repost & 12 & $9,52 \%$ & 8 & $7 \%$ & 4 & $57 \%$ \\
\hline E-37 Menção @ & 36 & $28,57 \%$ & 32 & $27 \%$ & 4 & $57 \%$ \\
\hline
\end{tabular}




\section{APÊNDICE C - PANORAMA NUMÉRICO DA ANÁLISE DA FOLHA}

\begin{tabular}{|c|c|c|c|c|c|c|c|c|}
\hline Indicadores Folha & Segunda & $16 \%$ & Terça & $14 \%$ & Quarta & $27 \%$ & Quinta & $18 \%$ \\
\hline Total de stories & 33 & $100 \%$ & 29 & $100 \%$ & 56 & $100 \%$ & 38 & $100 \%$ \\
\hline \multicolumn{9}{|l|}{ Temporalidade } \\
\hline \multicolumn{9}{|l|}{ F-39 Período do dia } \\
\hline Manhã & 8 & $24 \%$ & 4 & $14 \%$ & 17 & $30 \%$ & 5 & $13 \%$ \\
\hline Tarde & 3 & $9 \%$ & 0 & $0 \%$ & 15 & $27 \%$ & 5 & $13 \%$ \\
\hline Noite & 22 & $67 \%$ & 25 & $86 \%$ & 24 & $43 \%$ & 28 & $74 \%$ \\
\hline F-40 Urgente & 0 & $0 \%$ & 0 & $0 \%$ & 10 & $18 \%$ & 0 & $0 \%$ \\
\hline \multicolumn{9}{|l|}{ Temática } \\
\hline F-09 Presença humana & 24 & $73 \%$ & 20 & $69 \%$ & 36 & $64 \%$ & 24 & $63 \%$ \\
\hline F-20 Adesivo & 11 & $33 \%$ & 7 & $24 \%$ & 5 & $9 \%$ & 6 & $16 \%$ \\
\hline \multicolumn{9}{|l|}{ F-13 Assunto central } \\
\hline Política & 18 & $56 \%$ & 19 & $68 \%$ & 28 & $51 \%$ & 17 & $46 \%$ \\
\hline Coronavírus & 7 & $22 \%$ & 5 & $18 \%$ & 10 & $18 \%$ & 13 & $35 \%$ \\
\hline Internacional & 2 & $6 \%$ & 0 & $0 \%$ & 10 & $18 \%$ & 2 & $5 \%$ \\
\hline Economia & 0 & $0 \%$ & 2 & $7 \%$ & 0 & $0 \%$ & 0 & $0 \%$ \\
\hline Saúde & 3 & $9 \%$ & 0 & $0 \%$ & 0 & $0 \%$ & 0 & $0 \%$ \\
\hline Ciência & 0 & $0 \%$ & 0 & $0 \%$ & 5 & $9 \%$ & 0 & $0 \%$ \\
\hline Capa & 1 & $3 \%$ & 1 & $4 \%$ & 1 & $2 \%$ & 1 & $3 \%$ \\
\hline Expediente & 1 & $3 \%$ & 1 & $4 \%$ & 1 & $2 \%$ & 1 & $3 \%$ \\
\hline Webstories & 0 & $0 \%$ & 0 & $0 \%$ & 0 & $0 \%$ & 2 & $5 \%$ \\
\hline \multirow[t]{2}{*}{ Cultura } & 0 & $0 \%$ & 0 & $0 \%$ & 0 & $0 \%$ & 1 & $3 \%$ \\
\hline & 32 & $100 \%$ & 28 & $100 \%$ & 55 & $100 \%$ & 37 & $100 \%$ \\
\hline \multicolumn{9}{|l|}{ Referência } \\
\hline F-02 Layout personalizado & 3 & $9 \%$ & 2 & $7 \%$ & 0 & $0 \%$ & 7 & $18 \%$ \\
\hline F-03 Layout nativo & 30 & $91 \%$ & 27 & $93 \%$ & 56 & $100 \%$ & 31 & $82 \%$ \\
\hline F-17 Imagem jornalística & 18 & $55 \%$ & 22 & $76 \%$ & 37 & $66 \%$ & 25 & $66 \%$ \\
\hline F-18 Imagem reproduzida & 9 & $27 \%$ & 7 & $24 \%$ & 10 & $18 \%$ & 7 & $18 \%$ \\
\hline F-19 Não é possível saber & 3 & $9 \%$ & 0 & $0 \%$ & 4 & $7 \%$ & 8 & $21 \%$ \\
\hline F-15 Créditos dos stories & 1 & $3 \%$ & 1 & $3 \%$ & 1 & $2 \%$ & 1 & $3 \%$ \\
\hline F-14 Créditos das imagens & 1 & $3 \%$ & 1 & $3 \%$ & 1 & $2 \%$ & 1 & $3 \%$ \\
\hline \multirow[t]{2}{*}{ F-26 Texto semelhante } & 18 & $55 \%$ & 22 & $76 \%$ & 30 & $54 \%$ & 22 & $58 \%$ \\
\hline & só bc+ed. & $67 \%$; & ó bc+ed. & $92 \%$ & só bc+ed. & $56 \%$ & só bc+ed. & $69 \%$ \\
\hline \multicolumn{9}{|l|}{ Formato } \\
\hline F-04 vertical/full screen & 19 & $58 \%$ & 8 & $28 \%$ & 17 & $30 \%$ & 22 & $58 \%$ \\
\hline F-05 quadrada/horizontal & 14 & $42 \%$ & 21 & $72 \%$ & 39 & $70 \%$ & 16 & $42 \%$ \\
\hline \multicolumn{9}{|l|}{ F-06 Filtro } \\
\hline Com filtro & 4 & $12 \%$ & 1 & $3 \%$ & 8 & $14 \%$ & 8 & $21 \%$ \\
\hline Sem filtro & 29 & $88 \%$ & 28 & $97 \%$ & 48 & $86 \%$ & 30 & $79 \%$ \\
\hline F-07 Imagem estática & 21 & $64 \%$ & 21 & $72 \%$ & 51 & $91 \%$ & 30 & $79 \%$ \\
\hline F-08 Com movimento & 12 & $36 \%$ & 8 & $28 \%$ & 5 & $9 \%$ & 8 & $21 \%$ \\
\hline F-16 Jornalista selfie & 0 & $0 \%$ & 0 & $0 \%$ & 0 & $0 \%$ & 0 & $0 \%$ \\
\hline F-24 Texto & 33 & $100 \%$ & 29 & $100 \%$ & 56 & $100 \%$ & 38 & $100 \%$ \\
\hline F-28 Áudio & 2 & $6 \%$ & 0 & $0 \%$ & 0 & $0 \%$ & 0 & $0 \%$ \\
\hline F-25 Palavras por story & 18,5 & nédia & 23,2 & média & 22 & média & 22 & média \\
\hline
\end{tabular}




\begin{tabular}{|c|c|c|c|c|c|c|c|c|}
\hline \multicolumn{9}{|l|}{ Finalidade } \\
\hline F-10 Publicidade & 1 & $3 \%$ & 1 & $3 \%$ & 1 & $2 \%$ & 1 & $3 \%$ \\
\hline F-11 Branded content & 5 & $15 \%$ & 4 & $14 \%$ & 1 & $2 \%$ & 5 & $13 \%$ \\
\hline F-12 Editorial - Jornalismo & 27 & $82 \%$ & 24 & $83 \%$ & 54 & $96 \%$ & 32 & $84 \%$ \\
\hline BC + Editorial & 32 & & 28 & & 55 & & 37 & \\
\hline \multicolumn{9}{|l|}{ Interatividade } \\
\hline F-21 Localização & 0 & $0 \%$ & 0 & $0 \%$ & 0 & $0 \%$ & 0 & $0 \%$ \\
\hline F-22 Hashtag \# & 0 & $0 \%$ & 0 & $0 \%$ & 0 & $0 \%$ & 0 & $0 \%$ \\
\hline F-23 Tag de Música & 0 & $0 \%$ & 0 & $0 \%$ & 0 & $0 \%$ & 0 & $0 \%$ \\
\hline F-36 Interação (enquete) & 0 & $0 \%$ & 0 & $0 \%$ & 0 & $0 \%$ & 0 & $0 \%$ \\
\hline F-38 Mensagens diretas & 4 & $12 \%$ & 2 & $7 \%$ & 1 & $2 \%$ & 2 & $5 \%$ \\
\hline \multicolumn{9}{|l|}{ Hiperlink } \\
\hline F-29 Com link & 29 & $88 \%$ & 27 & $93 \%$ & 55 & $98 \%$ & 36 & $95 \%$ \\
\hline F-30 Com paywall & 23 & $70 \%$ & 22 & $76 \%$ & 53 & $95 \%$ & 28 & $74 \%$ \\
\hline F-31 Sem paywall & 0 & $0 \%$ & 0 & $0 \%$ & 0 & $0 \%$ & 2 & $5 \%$ \\
\hline F-32 Aplicativo & 5 & $15 \%$ & 4 & $14 \%$ & 1 & $2 \%$ & 5 & $13 \%$ \\
\hline F-33 Publicidade & 1 & $3 \%$ & 1 & $3 \%$ & 1 & $2 \%$ & 1 & $3 \%$ \\
\hline F-34 branded content & 5 & $15 \%$ & 4 & $14 \%$ & 1 & $2 \%$ & 5 & $13 \%$ \\
\hline F-35 Repost & 0 & $0 \%$ & 0 & $0 \%$ & 0 & $0 \%$ & 0 & $0 \%$ \\
\hline F-37 Menção @ & 0 & $0 \%$ & 0 & $0 \%$ & 1 & $2 \%$ & 2 & $5 \%$ \\
\hline
\end{tabular}




\begin{tabular}{|c|c|c|c|c|c|c|}
\hline Indicadores Folha & Sexta & $16 \%$ & Sábado & $5 \%$ & Domingo & $6 \%$ \\
\hline Total de stories & 33 & $100 \%$ & 10 & $100 \%$ & 12 & $100 \%$ \\
\hline \multicolumn{7}{|l|}{ Temporalidade } \\
\hline \multicolumn{7}{|l|}{ F-39 Período do dia } \\
\hline Manhã & 6 & $18 \%$ & 0 & $0 \%$ & 4 & $33 \%$ \\
\hline Tarde & 4 & $12 \%$ & 2 & $20 \%$ & 0 & $0 \%$ \\
\hline Noite & 23 & $70 \%$ & 8 & $80 \%$ & 8 & $67 \%$ \\
\hline F-40 Urgente & 0 & $0 \%$ & 1 & $10 \%$ & 0 & $0 \%$ \\
\hline \multicolumn{7}{|l|}{ Temática } \\
\hline F-09 Presença humana & 25 & $76 \%$ & 5 & $50 \%$ & 6 & $50 \%$ \\
\hline F-20 Adesivo & 6 & $18 \%$ & 3 & $30 \%$ & 2 & $17 \%$ \\
\hline \multicolumn{7}{|l|}{ F-13 Assunto central } \\
\hline Política & 2 & $6 \%$ & 1 & $11 \%$ & 4 & $57 \%$ \\
\hline Coronavírus & 8 & $25 \%$ & 2 & $22 \%$ & 1 & $14 \%$ \\
\hline Internacional & 10 & $31 \%$ & 1 & $11 \%$ & 0 & $0 \%$ \\
\hline Economia & 2 & $6 \%$ & 0 & $0 \%$ & 0 & $0 \%$ \\
\hline Saúde & 0 & $0 \%$ & 0 & $0 \%$ & 0 & $0 \%$ \\
\hline Ciência & 0 & $0 \%$ & 3 & $33 \%$ & 0 & $0 \%$ \\
\hline Capa & 1 & $3 \%$ & 1 & $11 \%$ & 1 & $14 \%$ \\
\hline Expediente & 1 & $3 \%$ & 1 & $11 \%$ & 1 & $14 \%$ \\
\hline Webstories & 0 & $0 \%$ & 0 & $0 \%$ & 0 & $0 \%$ \\
\hline \multirow[t]{2}{*}{ Cultura } & 8 & $25 \%$ & 0 & $0 \%$ & 0 & $0 \%$ \\
\hline & 32 & $100 \%$ & 9 & $100 \%$ & 7 & $100 \%$ \\
\hline \multicolumn{7}{|l|}{ Referência } \\
\hline F-02 Layout personalizado & 3 & $9 \%$ & 0 & $0 \%$ & 0 & $0 \%$ \\
\hline F-03 Layout nativo & 30 & $91 \%$ & 10 & $100 \%$ & 12 & $100 \%$ \\
\hline F-17 Imagem jornalística & 14 & $42 \%$ & 7 & $70 \%$ & 4 & $33 \%$ \\
\hline F-18 Imagem reproduzida & 13 & $39 \%$ & 3 & $30 \%$ & 5 & $42 \%$ \\
\hline F-19 Não é possível saber & 4 & $12 \%$ & 0 & $0 \%$ & 0 & $0 \%$ \\
\hline F-15 Créditos dos stories & 1 & $3 \%$ & 1 & $10 \%$ & 1 & $8 \%$ \\
\hline F-14 Créditos das imagens & 1 & $3 \%$ & 1 & $10 \%$ & 1 & $8 \%$ \\
\hline \multirow[t]{2}{*}{ F-26 Texto semelhante } & 21 & $64 \%$ & 6 & $60 \%$ & 5 & $42 \%$ \\
\hline & só bc+ed. & $75 \%$ & só bc+ed. & $67 \%$ & só bc+ed. & $71 \%$ \\
\hline \multicolumn{7}{|l|}{ Formato } \\
\hline F-04 vertical/full screen & 11 & $33 \%$ & 3 & $30 \%$ & 6 & $50 \%$ \\
\hline F-05 quadrada/horizontal & 22 & $67 \%$ & 7 & $70 \%$ & 6 & $50 \%$ \\
\hline \multicolumn{7}{|l|}{ F-06 Filtro } \\
\hline Com filtro & 11 & $33 \%$ & 1 & $10 \%$ & 1 & $8 \%$ \\
\hline Sem filtro & 22 & $67 \%$ & 9 & $90 \%$ & 11 & $92 \%$ \\
\hline F-07 Imagem estática & 26 & $79 \%$ & 7 & $70 \%$ & 10 & $83 \%$ \\
\hline F-08 Com movimento & 7 & $21 \%$ & 3 & $30 \%$ & 2 & $17 \%$ \\
\hline F-16 Jornalista selfie & 0 & $0 \%$ & 0 & $0 \%$ & 0 & $0 \%$ \\
\hline F-24 Texto & 33 & $100 \%$ & 10 & $100 \%$ & 12 & $100 \%$ \\
\hline F-28 Áudio & 0 & $0 \%$ & \multirow{2}{*}{\multicolumn{2}{|c|}{12 média }} & \multirow{2}{*}{\multicolumn{2}{|c|}{$\begin{array}{c}0 \\
13 \text { média }\end{array}$}} \\
\hline F-25 Palavras por story & \multicolumn{2}{|c|}{22 média } & & & & \\
\hline
\end{tabular}




\begin{tabular}{|c|c|c|c|c|c|c|}
\hline \multicolumn{7}{|l|}{ Finalidade } \\
\hline F-10 Publicidade & 1 & $3 \%$ & 1 & $10 \%$ & 5 & $42 \%$ \\
\hline F-11 Branded content & 4 & $12 \%$ & 0 & $0 \%$ & 0 & $0 \%$ \\
\hline F-12 Editorial - Jornalismo & 28 & $85 \%$ & 9 & $90 \%$ & 7 & $58 \%$ \\
\hline $\mathrm{BC}+$ Editorial & 32 & & 9 & & 7 & \\
\hline \multicolumn{7}{|l|}{ Interatividade } \\
\hline F-21 Localização & 0 & $0 \%$ & 0 & $0 \%$ & 0 & $0 \%$ \\
\hline F-22 Hashtag \# & 0 & $0 \%$ & 0 & $0 \%$ & 0 & $0 \%$ \\
\hline F-23 Tag de Música & 0 & $0 \%$ & 0 & $0 \%$ & 0 & $0 \%$ \\
\hline F-36 Interação (enquete) & 0 & $0 \%$ & 0 & $0 \%$ & 1 & $8 \%$ \\
\hline F-38 Mensagens diretas & 1 & $3 \%$ & 2 & $20 \%$ & 2 & $17 \%$ \\
\hline \multicolumn{7}{|l|}{ Hiperlink } \\
\hline F-29 Com link & 32 & $97 \%$ & 8 & $80 \%$ & 10 & $83 \%$ \\
\hline F-30 Com paywall & 25 & $76 \%$ & 7 & $70 \%$ & 5 & $42 \%$ \\
\hline F-31 Sem paywall & 0 & $0 \%$ & 0 & $0 \%$ & 0 & $0 \%$ \\
\hline F-32 Aplicativo & 6 & $18 \%$ & 0 & $0 \%$ & 0 & $0 \%$ \\
\hline F-33 Publicidade & 1 & $3 \%$ & 1 & $10 \%$ & 5 & $42 \%$ \\
\hline F-34 branded content & 4 & $12 \%$ & 0 & $0 \%$ & 0 & $0 \%$ \\
\hline F-35 Repost & 0 & $0 \%$ & 0 & $0 \%$ & 0 & $0 \%$ \\
\hline F-37 Menção @ & 3 & $9 \%$ & 0 & $0 \%$ & 1 & $8 \%$ \\
\hline
\end{tabular}




\begin{tabular}{|c|c|c|c|c|c|c|}
\hline Indicadores Folha & SEMANAL & $\%$ total & SEG-SEX & $\%$ total & $\begin{array}{l}\text { FIM DE } \\
\text { SEMANA }\end{array}$ & $\%$ total \\
\hline Total de stories & 211 & $100 \%$ & 189 & $100 \%$ & 22 & $100 \%$ \\
\hline \multicolumn{7}{|l|}{ Temporalidade } \\
\hline \multicolumn{7}{|l|}{ F-39 Período do dia } \\
\hline Manhã & 44 & $21 \%$ & 40 & $21 \%$ & 4 & $18 \%$ \\
\hline Tarde & 29 & $14 \%$ & 27 & $14 \%$ & 2 & $9 \%$ \\
\hline Noite & 138 & $65 \%$ & 122 & $65 \%$ & 16 & $73 \%$ \\
\hline F-40 Urgente & 11 & $5 \%$ & 10 & $5 \%$ & 1 & $5 \%$ \\
\hline \multicolumn{7}{|l|}{ Temática } \\
\hline F-09 Presença humana & 140 & $66 \%$ & 129 & $68 \%$ & 11 & $50 \%$ \\
\hline F-20 Adesivo & 40 & $19 \%$ & 35 & $19 \%$ & 5 & $23 \%$ \\
\hline \multicolumn{7}{|l|}{ F-13 Assunto central } \\
\hline Política & 89 & $45 \%$ & 84 & $46 \%$ & 5 & $31 \%$ \\
\hline Coronavírus & 46 & $23 \%$ & 43 & $23 \%$ & 3 & $19 \%$ \\
\hline Internacional & 25 & $13 \%$ & 24 & $13 \%$ & 1 & $6 \%$ \\
\hline Economia & 4 & $2 \%$ & 4 & $2 \%$ & 0 & $0 \%$ \\
\hline Saúde & 3 & $2 \%$ & 3 & $2 \%$ & 0 & $0 \%$ \\
\hline Ciência & 8 & $4 \%$ & 5 & $3 \%$ & 3 & $19 \%$ \\
\hline Capa & 7 & $4 \%$ & 5 & $3 \%$ & 2 & $13 \%$ \\
\hline Expediente & 7 & $4 \%$ & 5 & $3 \%$ & 2 & $13 \%$ \\
\hline Webstories & 2 & $1 \%$ & 2 & $1 \%$ & 0 & $0 \%$ \\
\hline \multirow[t]{2}{*}{ Cultura } & 9 & $5 \%$ & 9 & $5 \%$ & 0 & $0 \%$ \\
\hline & 200 & $100 \%$ & 184 & $100 \%$ & 16 & $100 \%$ \\
\hline \multicolumn{7}{|l|}{ Referência } \\
\hline F-02 Layout personalizado & 15 & $7 \%$ & 15 & $8 \%$ & 0 & $0 \%$ \\
\hline F-03 Layout nativo & 196 & $93 \%$ & 174 & $92 \%$ & 22 & $100 \%$ \\
\hline F-17 Imagem jornalística & 127 & $60 \%$ & 116 & $61 \%$ & 11 & $50 \%$ \\
\hline F-18 Imagem reproduzida & 54 & $26 \%$ & 46 & $24 \%$ & 8 & $36 \%$ \\
\hline F-19 Não é possível saber & 19 & $9 \%$ & 19 & $10 \%$ & 0 & $0 \%$ \\
\hline F-15 Créditos dos stories & 7 & $3 \%$ & 5 & $3 \%$ & 2 & $9 \%$ \\
\hline F-14 Créditos das imagens & 7 & $3 \%$ & 5 & $3 \%$ & 2 & $9 \%$ \\
\hline \multirow[t]{2}{*}{ F-26 Texto semelhante } & 124 & $59 \%$ & 113 & $60 \%$ & 11 & $50 \%$ \\
\hline & só bc+ed. & $62 \%$ & só bc+ed. & $61 \%$ & só bc+ed. & $69 \%$ \\
\hline \multicolumn{7}{|l|}{ Formato } \\
\hline F-04 vertical/full screen & 86 & $41 \%$ & 77 & $41 \%$ & 9 & $41 \%$ \\
\hline F-05 quadrada/horizontal & 125 & $59 \%$ & 112 & $59 \%$ & 13 & $59 \%$ \\
\hline F-06 Filtro & & & 0 & $0 \%$ & 0 & $0 \%$ \\
\hline Com filtro & 34 & $16 \%$ & 32 & $17 \%$ & 2 & $9 \%$ \\
\hline Sem filtro & 177 & $84 \%$ & 157 & $83 \%$ & 20 & $91 \%$ \\
\hline F-07 Imagem estática & 166 & $79 \%$ & 149 & $79 \%$ & 17 & $77 \%$ \\
\hline F-08 Com movimento & 45 & $21 \%$ & 40 & $21 \%$ & 5 & $23 \%$ \\
\hline F-16 Jornalista selfie & 0 & $0 \%$ & 0 & $0 \%$ & 0 & $0 \%$ \\
\hline F-24 Texto & 211 & $100 \%$ & 189 & $100 \%$ & 22 & $100 \%$ \\
\hline F-28 Áudio & 2 & $1 \%$ & 2 & $1 \%$ & 0 & $0 \%$ \\
\hline F-25 Palavras por story & 20,5 & média & 21,5 & média & 12,3 & média \\
\hline
\end{tabular}




\begin{tabular}{|c|c|c|c|c|c|c|}
\hline \multicolumn{7}{|l|}{ Finalidade } \\
\hline F-10 Publicidade & 11 & $5 \%$ & 5 & $3 \%$ & 6 & $27 \%$ \\
\hline F-11 Branded content & 19 & $9 \%$ & 19 & $10 \%$ & 0 & $0 \%$ \\
\hline F-12 Editorial - Jornalismo & 181 & $86 \%$ & 165 & $87 \%$ & 16 & $73 \%$ \\
\hline BC + Editorial & 200 & $95 \%$ & 184 & $97 \%$ & 16 & $73 \%$ \\
\hline \multicolumn{7}{|l|}{ Interatividade } \\
\hline F-21 Localização & 0 & $0,00 \%$ & 0 & $0 \%$ & 0 & $0 \%$ \\
\hline F-22 Hashtag \# & 0 & $0,00 \%$ & 0 & $0 \%$ & 0 & $0 \%$ \\
\hline F-23 Tag de Música & 0 & $0,00 \%$ & 0 & $0 \%$ & 0 & $0 \%$ \\
\hline F-36 Interação (enquete) & 1 & $0,47 \%$ & 0 & $0 \%$ & 1 & $5 \%$ \\
\hline F-38 Mensagens diretas & 14 & $6,64 \%$ & 10 & $5 \%$ & 4 & $18 \%$ \\
\hline \multicolumn{7}{|l|}{ Hiperlink } \\
\hline F-29 Com link & 197 & $93 \%$ & 179 & $95 \%$ & 18 & $82 \%$ \\
\hline F-30 Com paywall & 163 & $77 \%$ & 151 & $80 \%$ & 12 & $55 \%$ \\
\hline F-31 Sem paywall & 2 & $1 \%$ & 2 & $1 \%$ & 0 & $0 \%$ \\
\hline F-32 Aplicativo & 21 & $10 \%$ & 21 & $11 \%$ & 0 & $0 \%$ \\
\hline F-33 Publicidade & 11 & $5 \%$ & 5 & $3 \%$ & 6 & $27 \%$ \\
\hline F-34 branded content & 19 & $9 \%$ & 19 & $10 \%$ & 0 & $0 \%$ \\
\hline F-35 Repost & 0 & $0 \%$ & 0 & $0 \%$ & 0 & $0 \%$ \\
\hline F-37 Menção @ & 7 & $3 \%$ & 6 & $3 \%$ & 1 & $5 \%$ \\
\hline
\end{tabular}




\section{APÊNDICE D - GRÁFICOS DOS RESULTADOS DA ANÁLISE DO ESTADÃO}

Finalidade dos stories do Estadão

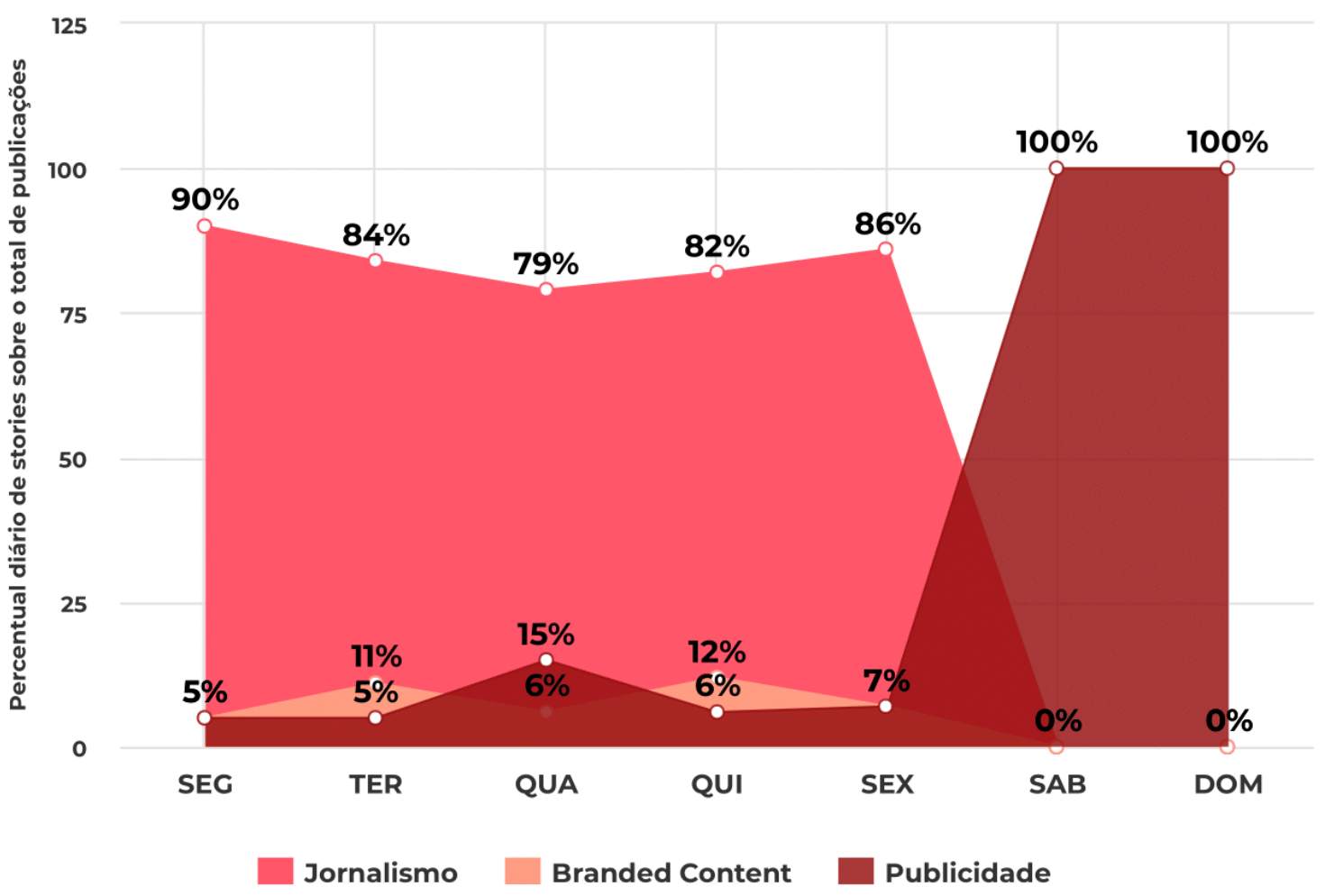

Distribuição semanal dos stories do Estadão

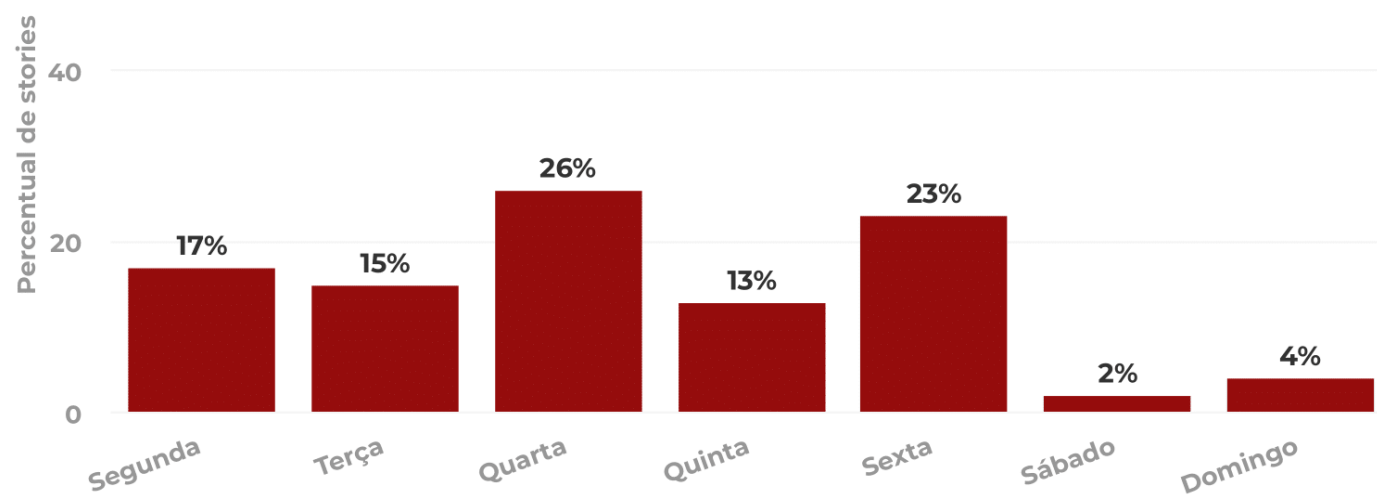


[E-02-03] Tipo de layout dos stories (total semanal)

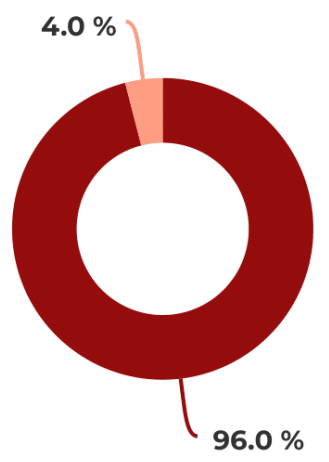

Semelhante ao Instagram

Design personalizado

[E-04-05] Formato predominante da imagem (total semanal)

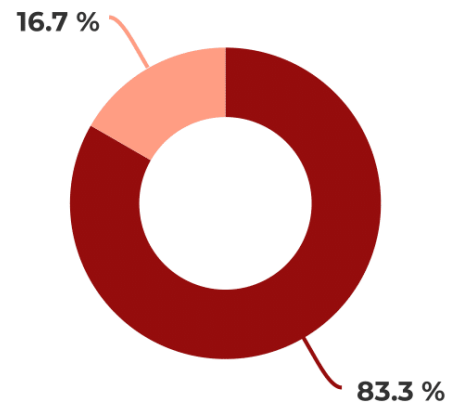

Vertical

Horizontal

[E-06] Presença de imagens

com filtro (total semanal)

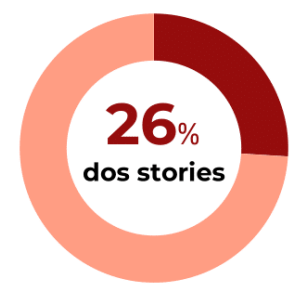

Stories com alguma funcionalidade interativa (total semanal)

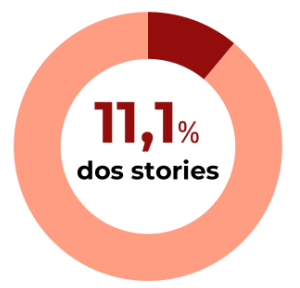


[E-07-08] Tipo de imagem (total semanal)

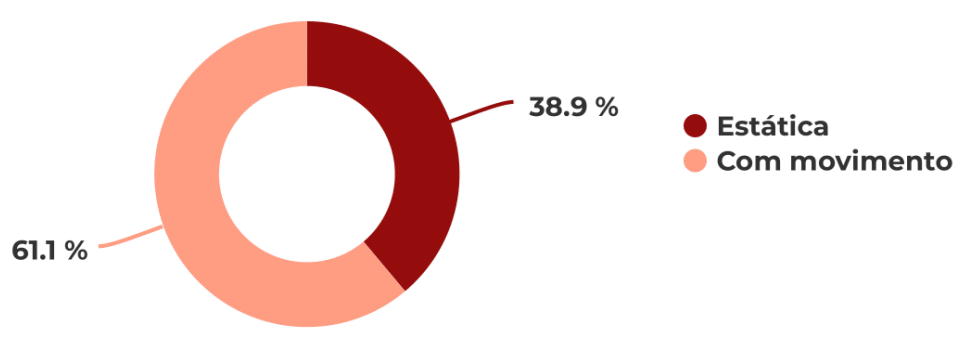

\section{[E-09] Presença humana na imagem (total semanal)}

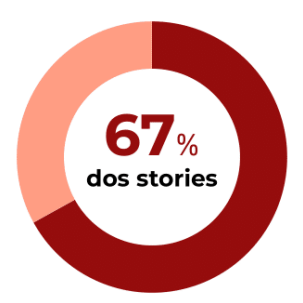

[E-10-11-12] Finalidade dos stories (total semanal)

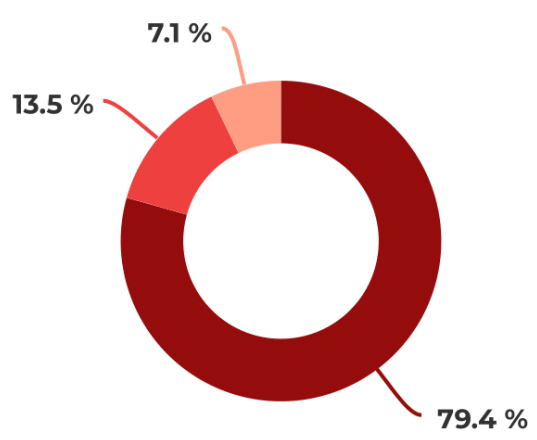

Editorial (Jornalismo)

Publicidade

Branded content

[E-13] Distribuição temática dos stories (jornalismo + branded content)

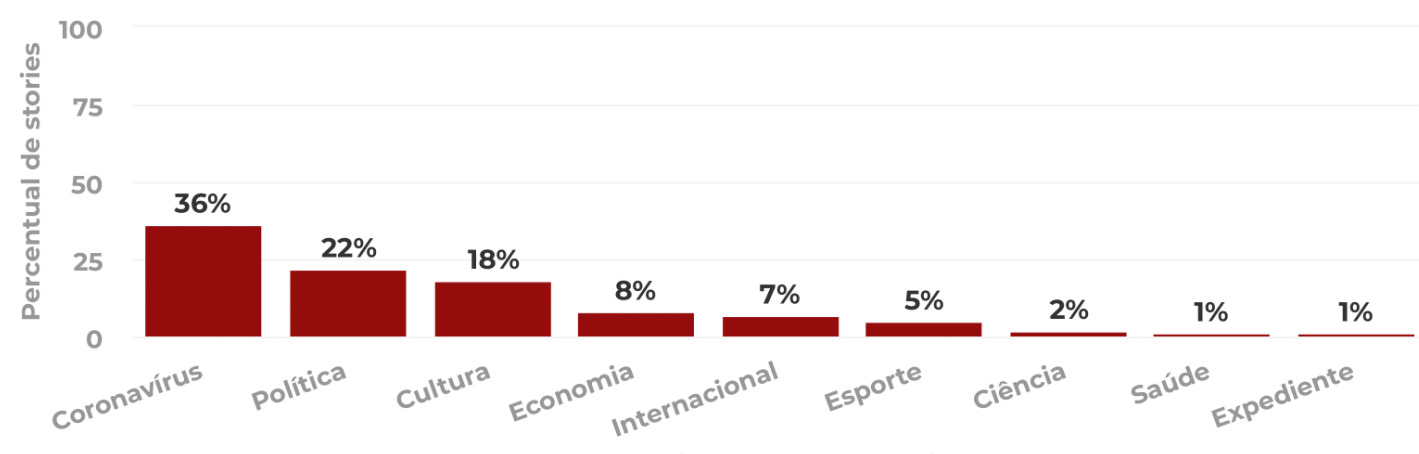

Temática central dos stories 
[E-13b] Ocorrência das 5 temáticas mais postadas (segunda a sexta)*

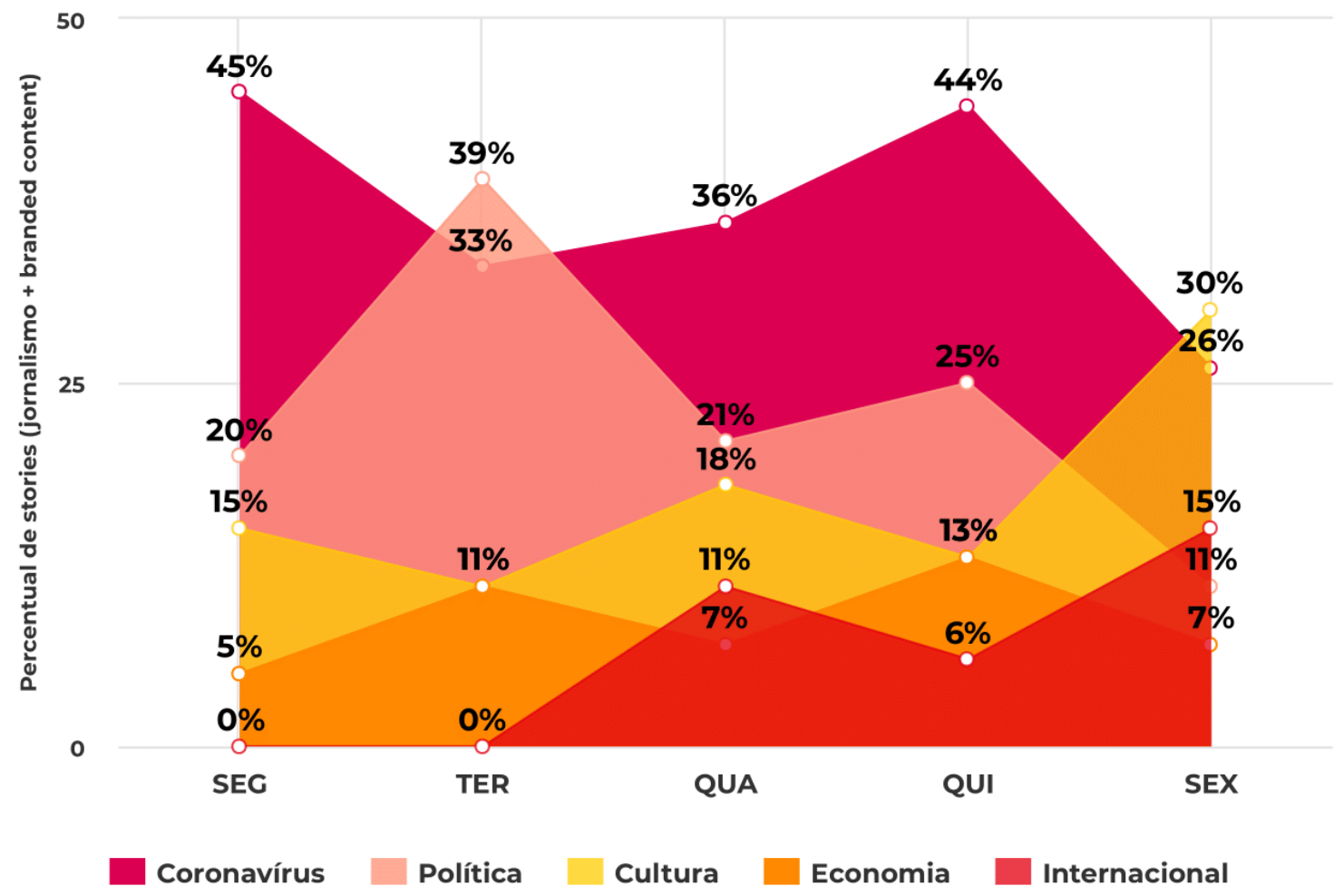

*No sábado e domingo analisados a conta do Estadão não publicou conteúdo editorial, apenas publicitário.

[E-17-18-19] Origem das imagens (total semanal)

Imagem jornalística

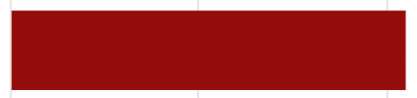

$\mathbf{4 2 \%}$

Imagem reproduzida

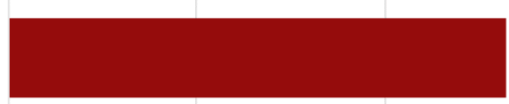

$53 \%$

Não é possível identificar

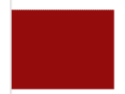

$11 \%$

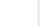

0

20

40

60

80

100

[E-20] Presença de imagens com emojis/gifs (total semanal)

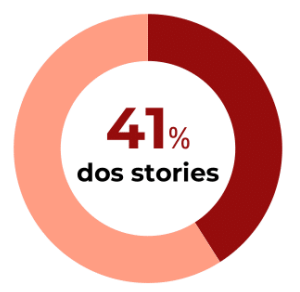


[E-24] Presença de texto nos stories (total semanal)

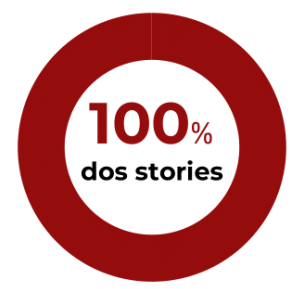

[E-26] Texto semelhante ao texto do site (total semanal)
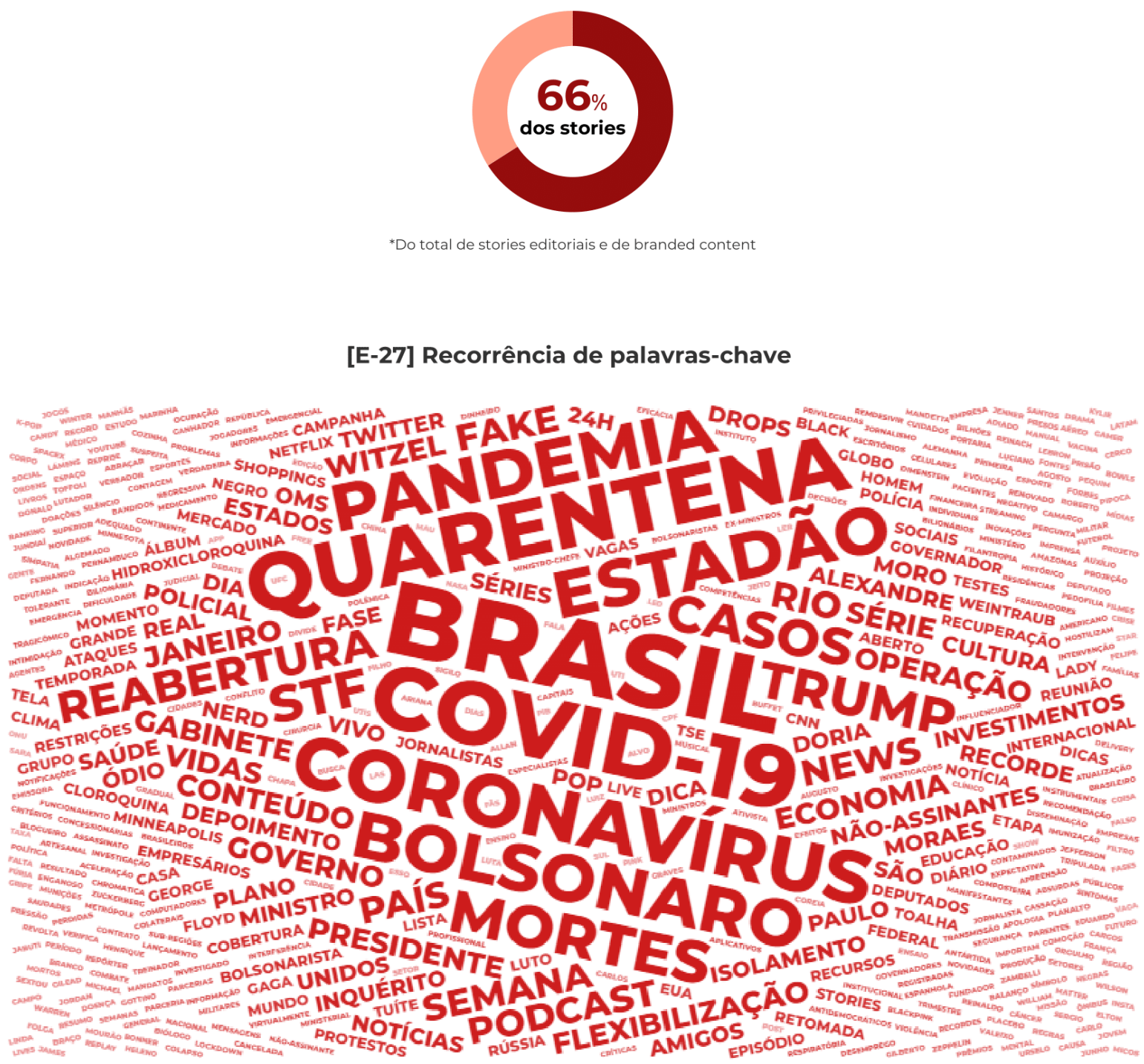
[E-28] Presença de áudio nos stories (total semanal)

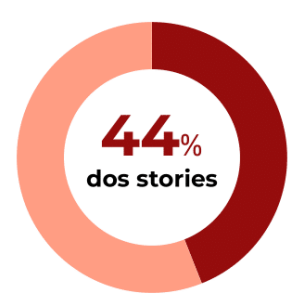

\begin{abstract}
[E-29] Presença de link
\end{abstract} externo (total semanal)

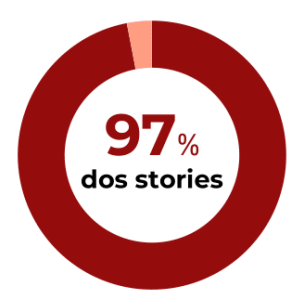

Percentual de hiperlinks nos stories do Estadão (total semanal)

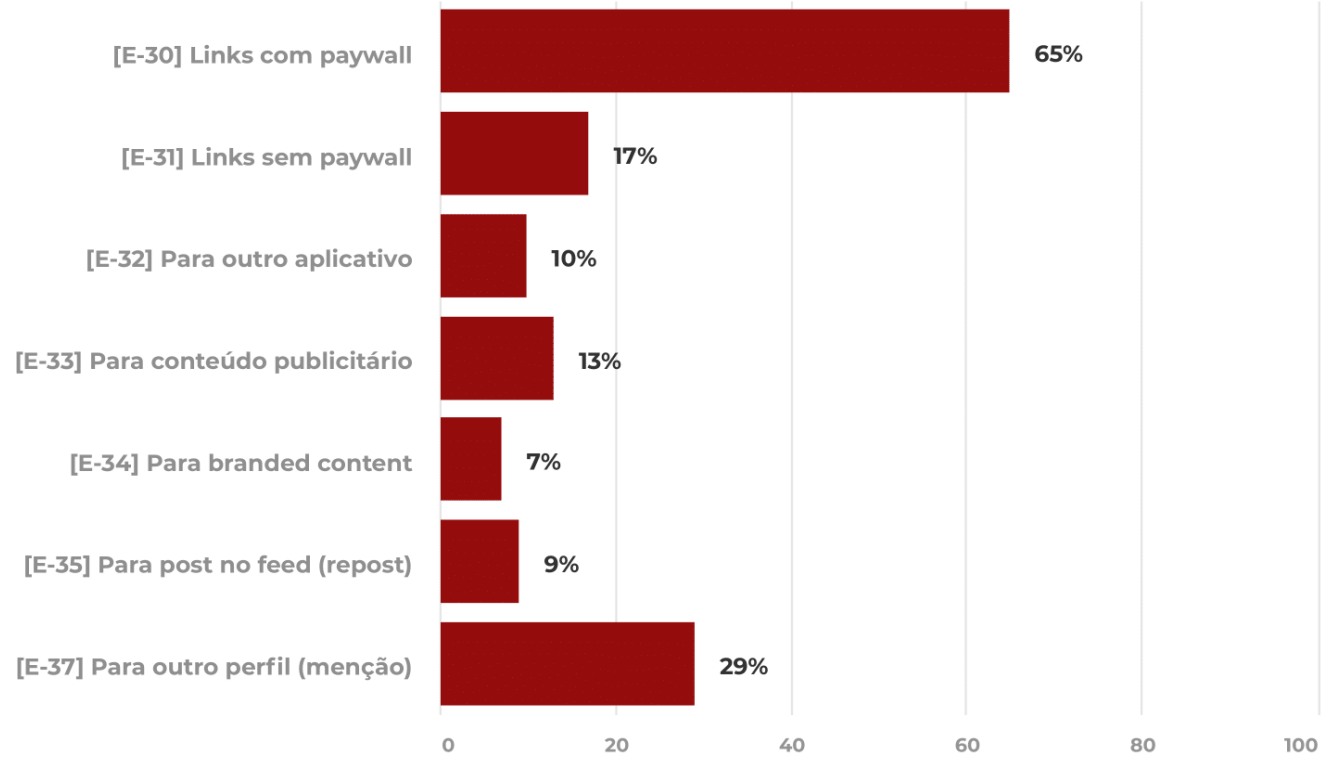




\section{[E-38] Stories que permitem}

mensagem direta (DM)

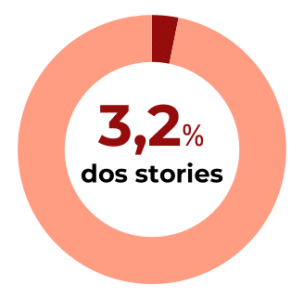

[E-39] Período do dia em que o story foi publicado (total semanal)

Manhã

$1.6 \%$

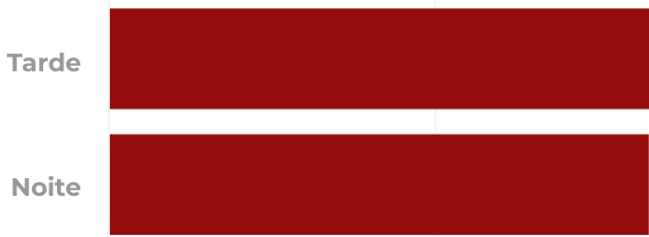

$57.1 \%$

$41.3 \%$

25

50

75

100

Percentual de stories 


\section{APÊNDICE E - GRÁFICOS DOS RESULTADOS DA ANÁLISE DA FOLHA}

Finalidade dos stories da Folha

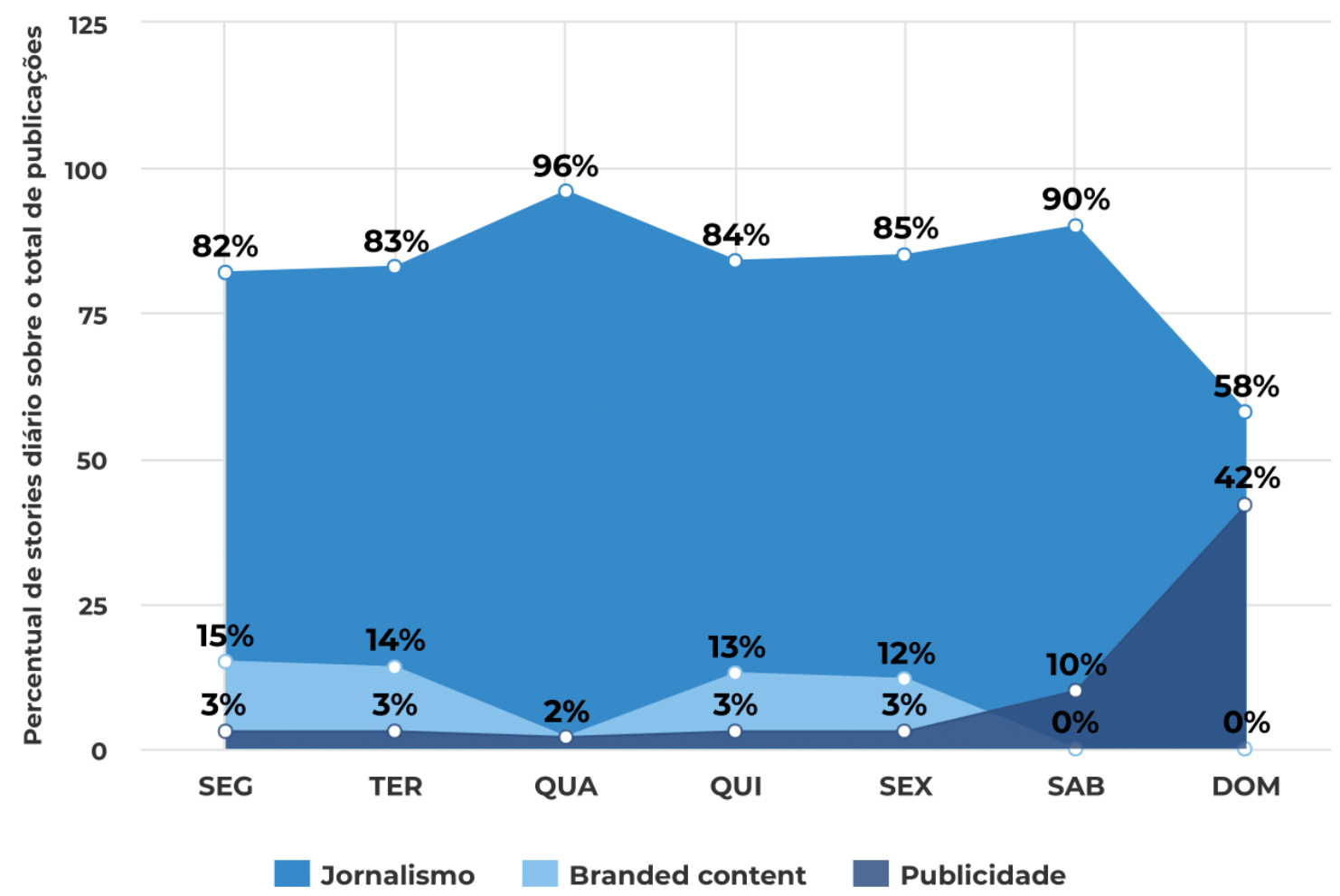

Distribuição semanal dos stories da Folha de S. Paulo

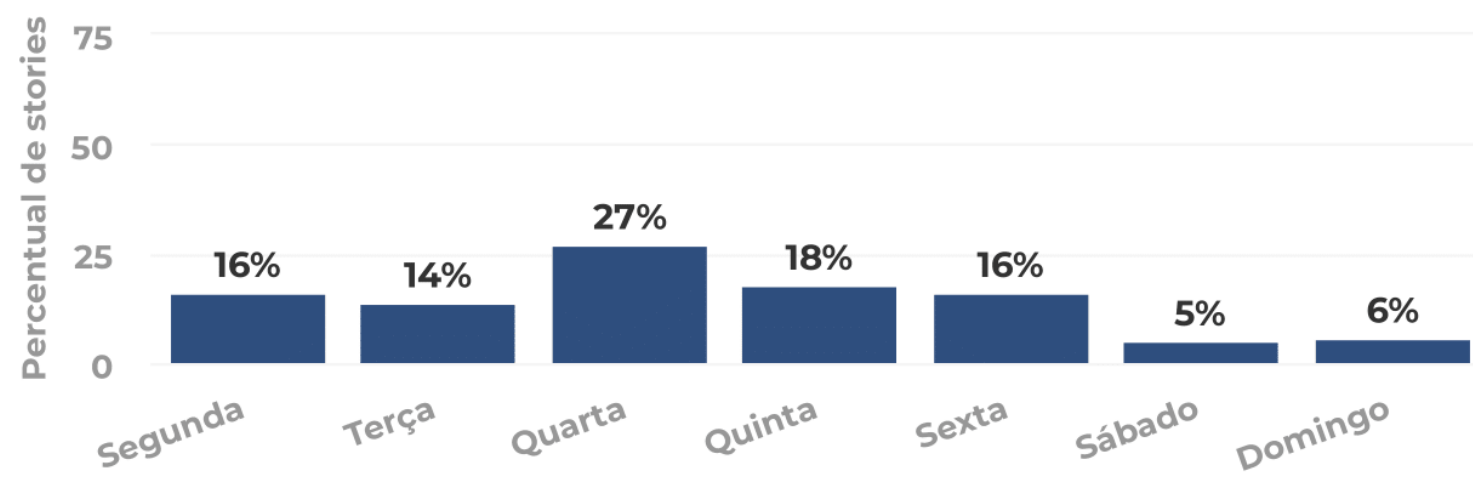


[F-02-03] Tipo de layout dos stories (total semanal)

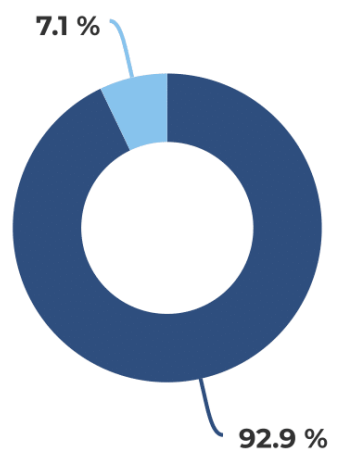

- Semelhante ao Instagram

Design personalizado

[F-04-05] Formato predominante da imagem (total semanal)

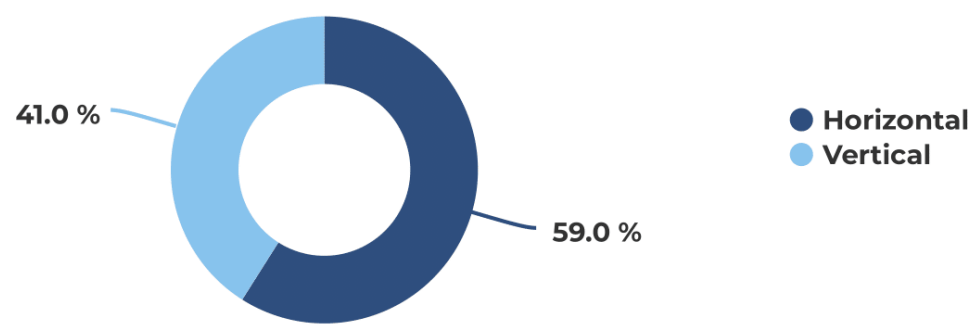

[F-06] Presença de imagens com filtro (total semanal)

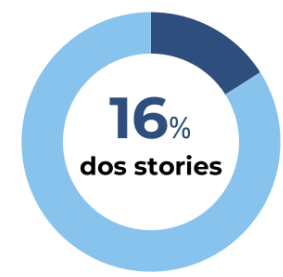

Stories com alguma funcionalidade interativa (total semanal)

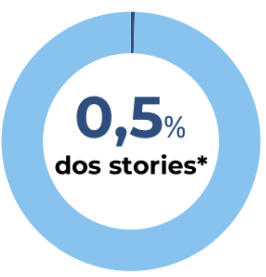




\section{[F-07-08] Tipo de imagem (total semanal)}

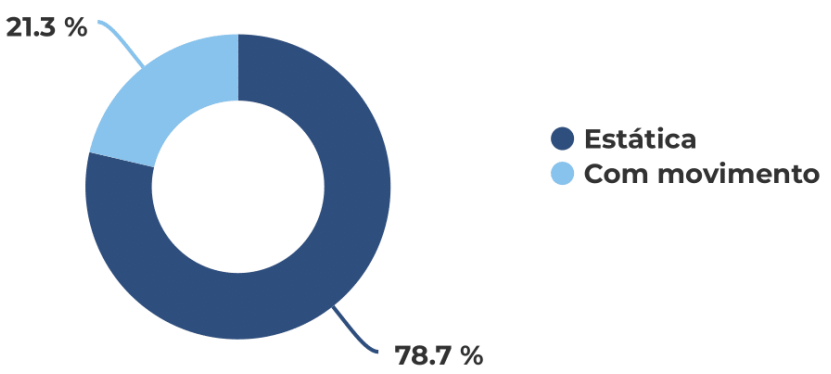

[F-09] Presença humana na imagem (total semanal)

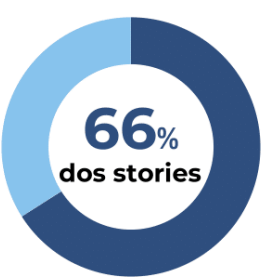

[F-10-11-12] Finalidade dos stories (total semanal)

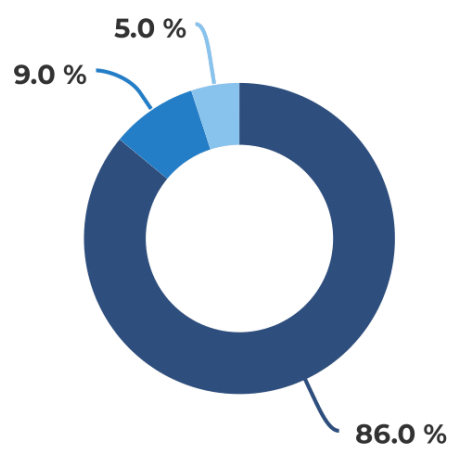

Editorial (Jornalismo)

Branded content

Publicidade

[F-13] Distribuição temática dos stories (jornalismo + branded content)

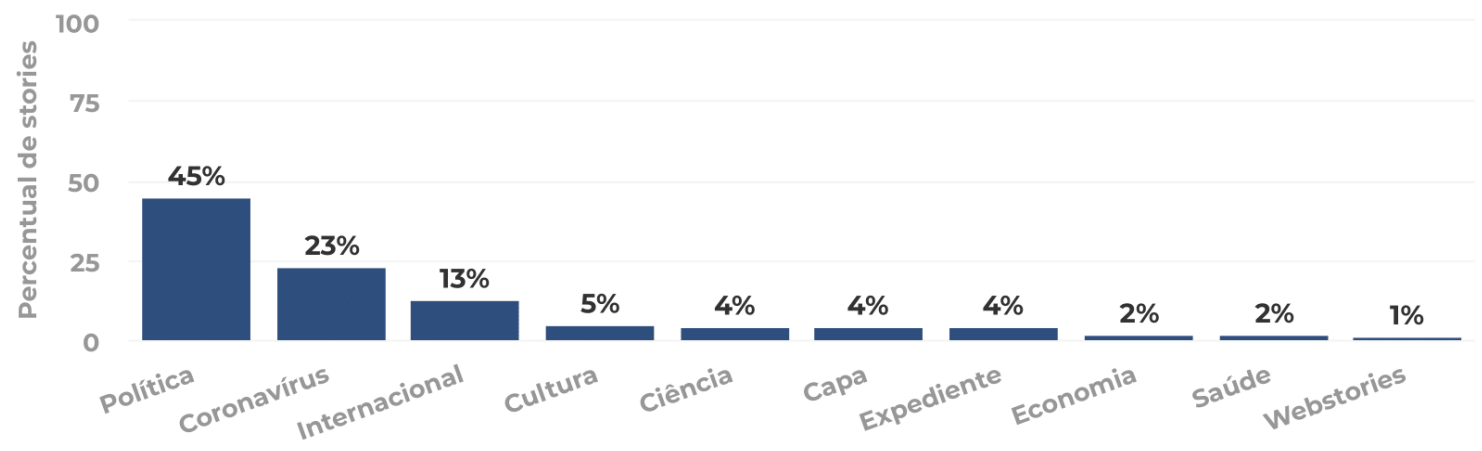

Temática central dos stories 
[F-13b] Ocorrência das 5 temáticas mais postadas (segunda a domingo)

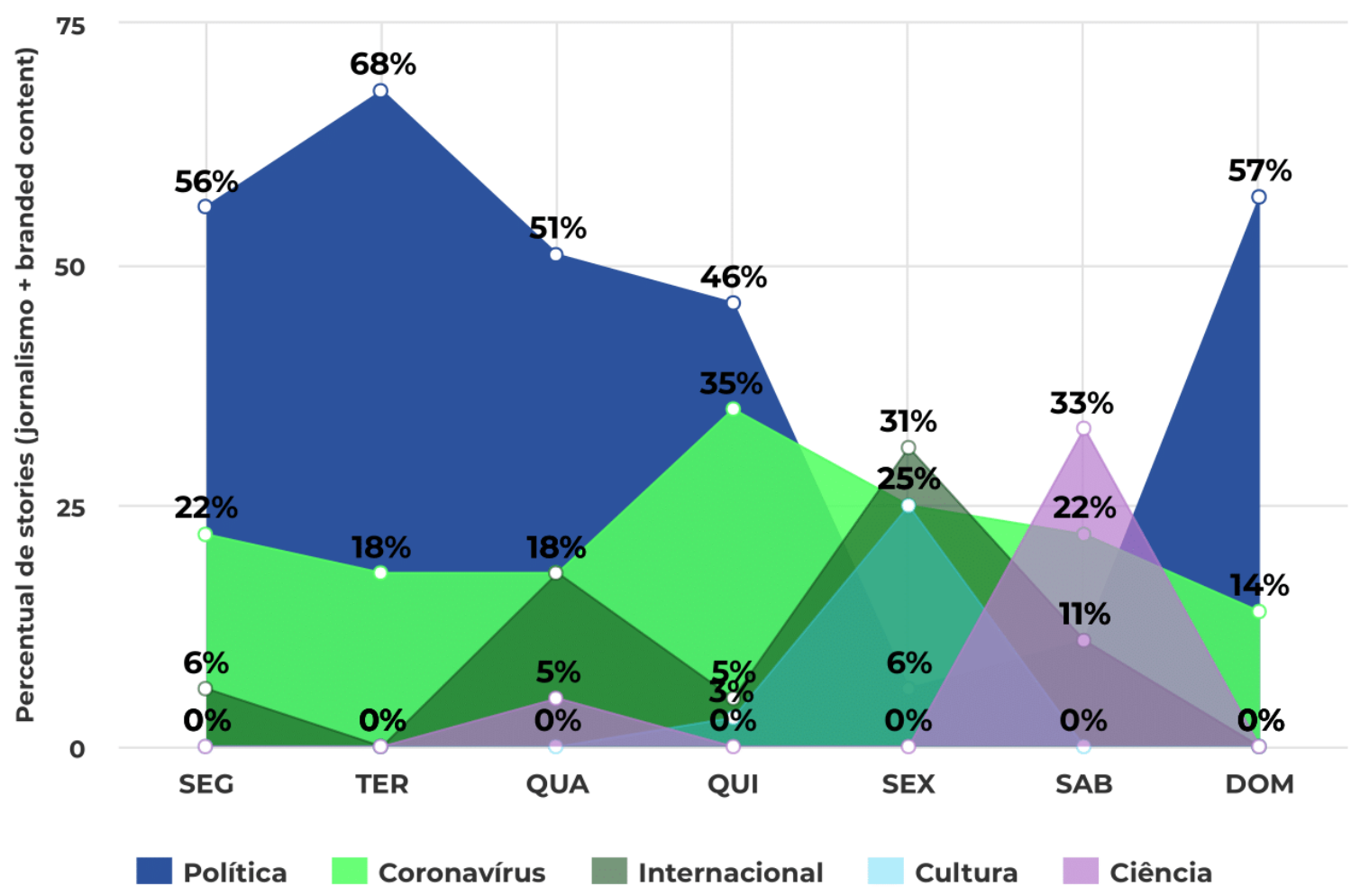

[F-17-18-19] Origem das imagens (total semanal)

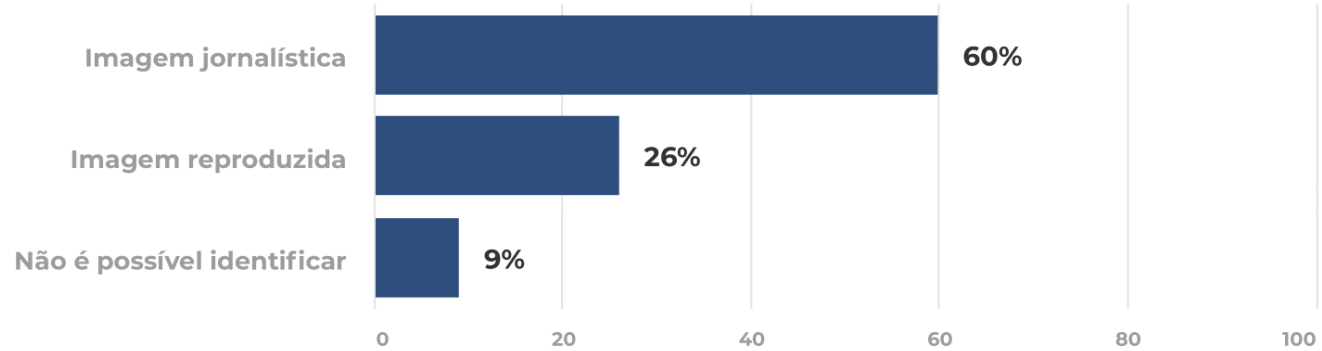

[F-20] Presença de imagens com emojis/gifs (total semanal)

\section{9\%}

dos stories 
[F-24] Presença de texto nos stories (total semanal)

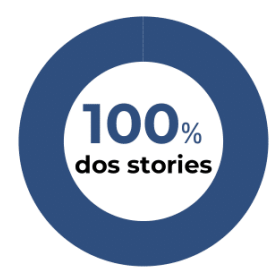

[F-26] Stories com texto semelhante ao texto do site (total semanal)

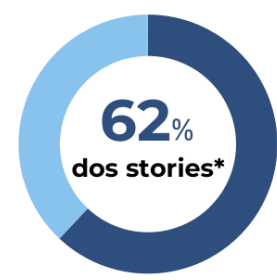

${ }^{*}$ Do total de stories editoriais e de branded content

[F-27] Recorrência de palavras-chave

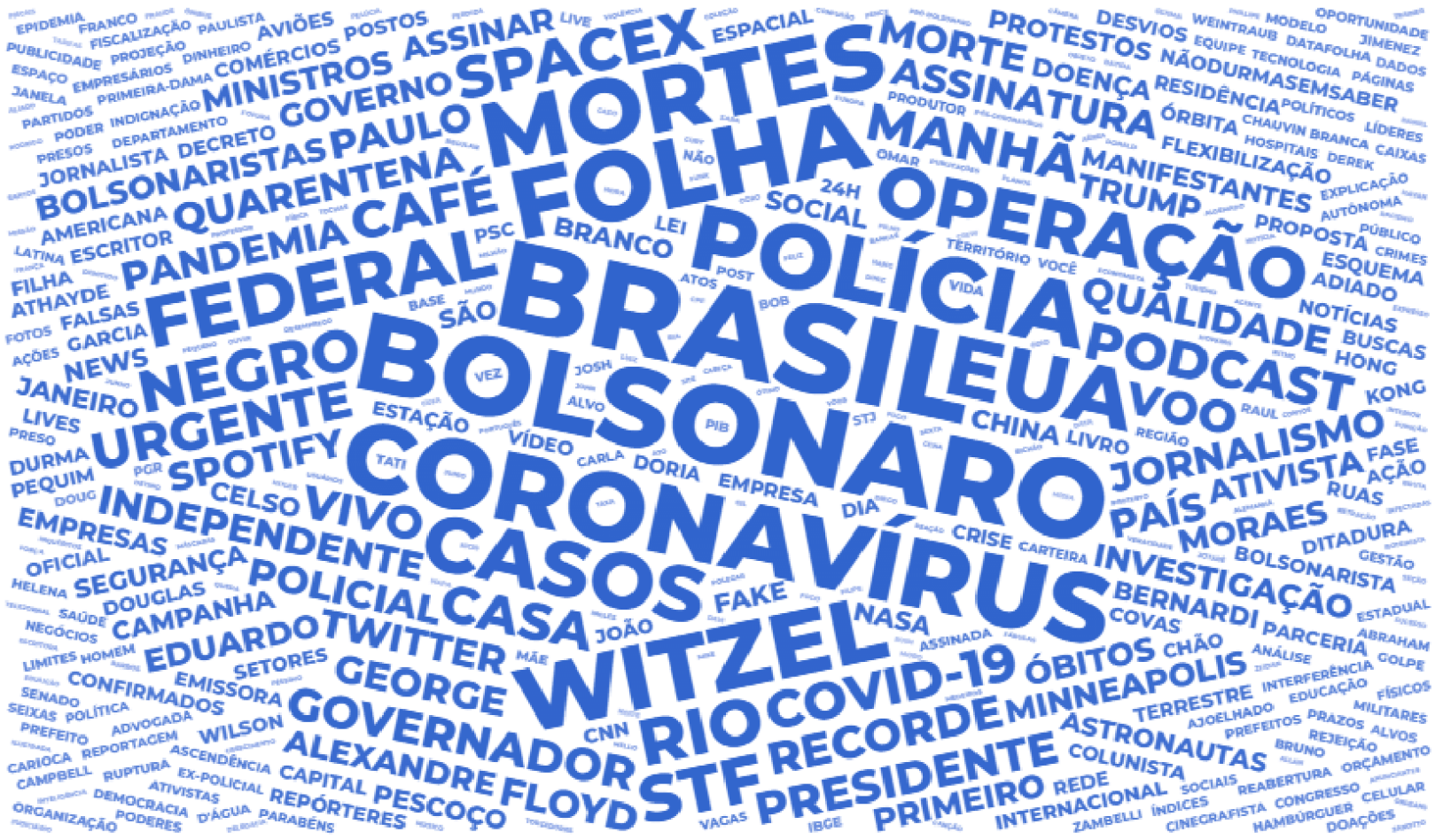




\section{[F-28] Presença de áudio nos stories}

(total semanal)

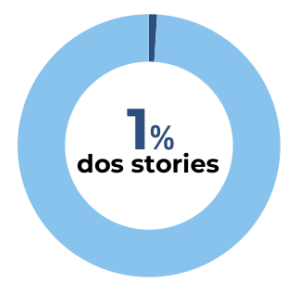

[F-29] Presença de link externo (total semanal)

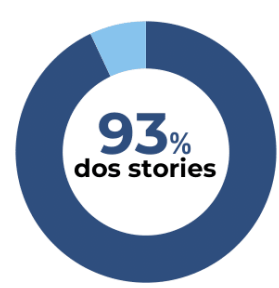

Percentual de hiperlinks nos stories da Folha de S. Paulo (total semanal)

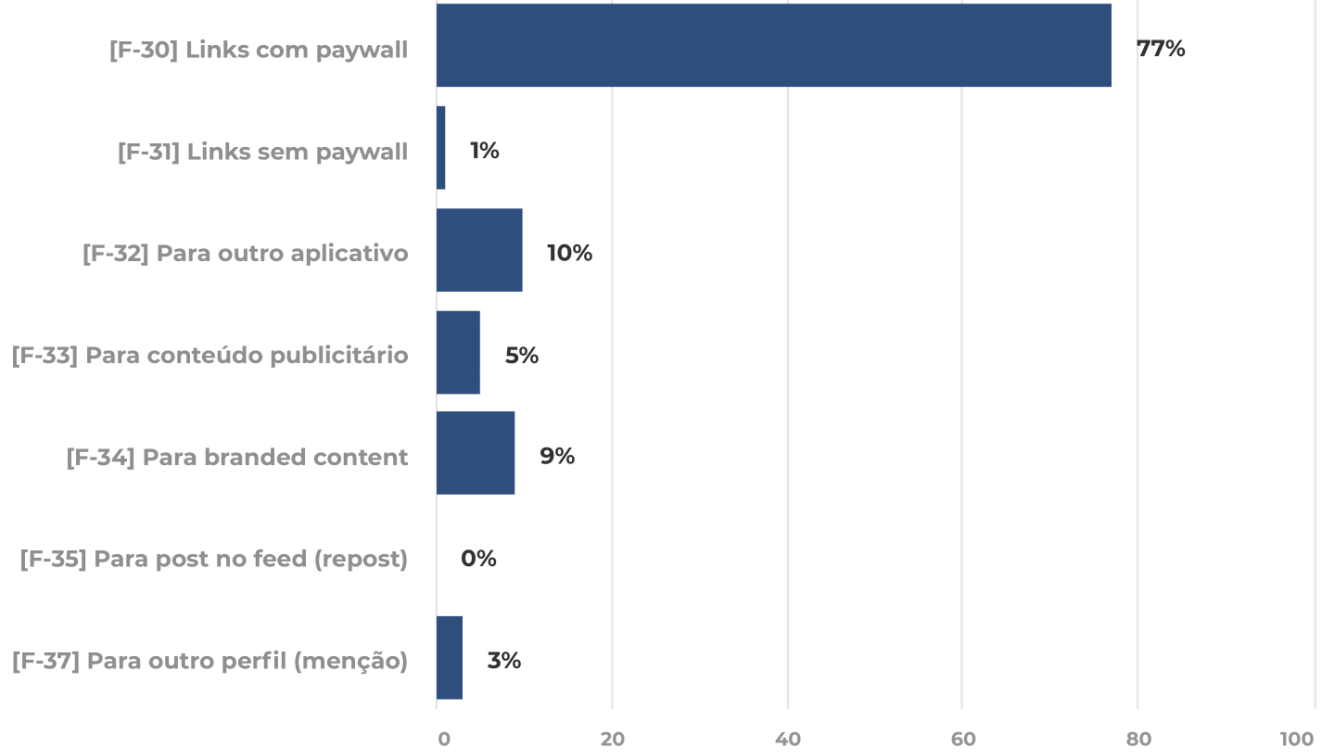




\section{[F-38] Stories quem permitem}

mensagem direta (DM)

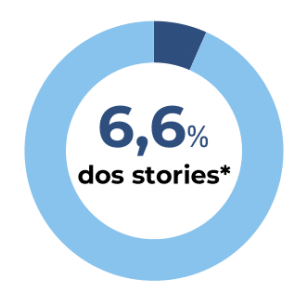

[F-39] Período do dia em que o story foi publicado (total semanal)

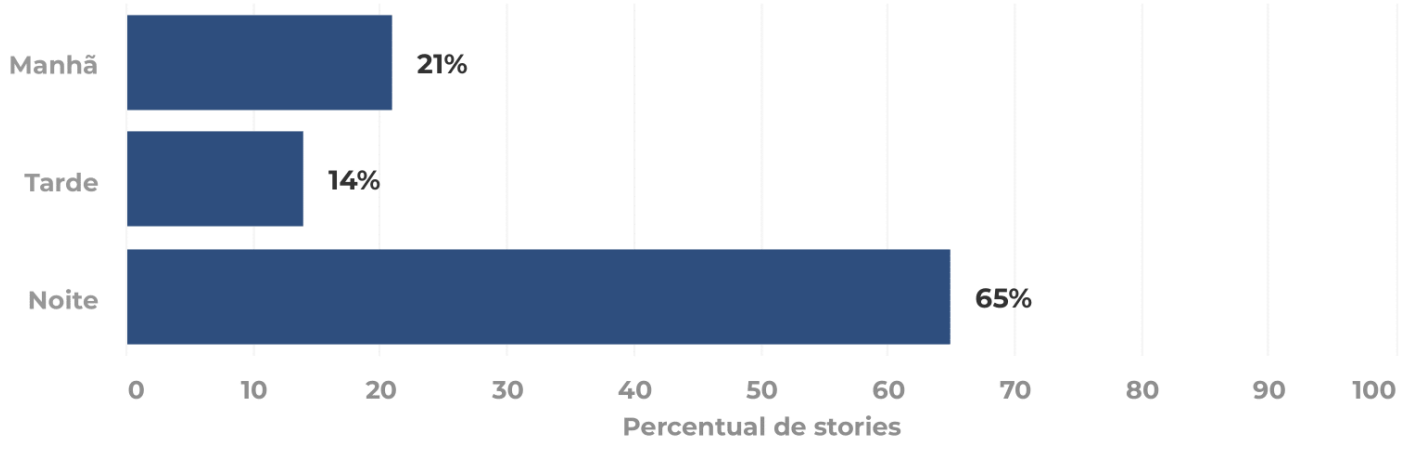

